Prepared for the U.S. Department of Energy

under Contract DE-AC05-76RL01830

\title{
Energy Provisions of the ICC-700, LEED for Homes, and ENERGY STAR Mapped to the 2009 IECC
}

ML Britt

R Sullivan

A Kora

EJ Makela

EKB Makela

May 2011

Pacific Northwest

NATIONAL LABORATORY

Proudly Operated by Battelle Since 1965 


\title{
DISCLAIMER
}

This report was prepared as an account of work sponsored by an agency of the United States Government. Neither the United States Government nor any agency thereof, nor Battelle Memorial Institute, nor any of their employees, makes any warranty, express or implied, or assumes any legal liability or responsibility for the accuracy, completeness, or usefulness of any information, apparatus, product, or process disclosed, or represents that its use would not infringe privately owned rights. Reference herein to any specific commercial product, process, or service by trade name, trademark, manufacturer, or otherwise does not necessarily constitute or imply its endorsement, recommendation, or favoring by the United States Government or any agency thereof, or Battelle Memorial Institute. The views and opinions of authors expressed herein do not necessarily state or reflect those of the United States Government or any agency thereof.

\author{
PACIFIC NORTHWEST NATIONAL LABORATORY \\ operated by \\ BATTELLE \\ for the \\ UNITED STATES DEPARTMENT OF ENERGY \\ under Contract DE-AC05-76RL01830
}

Printed in the United States of America
Available to DOE and DOE contractors from the Office of Scientific and Technical Information,
P.O. Box 62, Oak Ridge, TN 37831-0062;
ph: (865) 576-8401
fax: (865) 576-5728
email: reports@adonis.osti.gov

\author{
Available to the public from the National Technical Information Service, \\ U.S. Department of Commerce, 5285 Port Royal Rd., Springfield, VA 22161 \\ ph: (800) 553-6847 \\ fax: $(703) 605-6900$ \\ email: orders@ntis.fedworld.gov \\ online ordering: http://www.ntis.gov/ordering.htm
}

This document was printed on recycled paper. 


\title{
Energy Provisions of the ICC-700, LEED for Homes, and ENERGY STAR Mapped to the 2009 IECC
}

\author{
ML Britt \\ R Sullivan \\ A Kora \\ EJ Makela \\ EKB Makela
}

May 2011

Prepared for

the U.S. Department of Energy

under Contract DE-AC05-76RL01830

Pacific Northwest National Laboratory

Richland, Washington 99352 


\section{Summary}

This document provides the results of a comparison of building energy efficient elements of the ICC-700 National Green Building Standard, LEED for Homes, and ENERGY STAR versions 2, 2.5, and 3.0 to the 2009 International Energy Conservation Code (2009 IECC). This comparison will provide a tool for states and local municipalities as they consider adoption of these programs. The comparison is presented in a series of appendices. The first appendix provides a summary chart that visually represents the comprehensive comparison of the programs to the 2009 IECC topic areas. Next there are a series of individual tables (one appendix for each program) that include the specific program mapping to the 2009 IECC elements with comments that briefly discuss how well the elements mapped. Finally, a comprehensive table is included that shows all five of the programs mapped to the 2009 IECC elements to allow a detailed comparison. 



\section{Table of Contents}

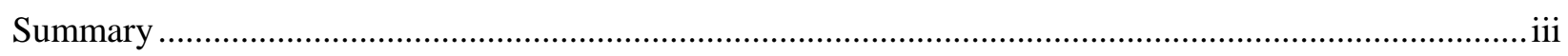

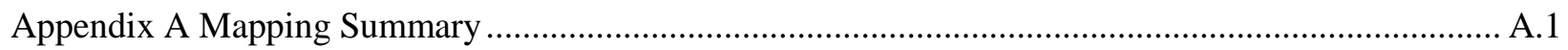

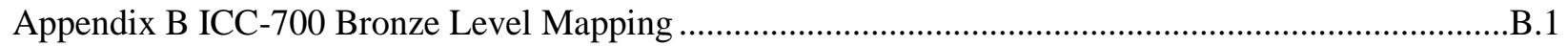

Appendix C LEED for Homes Certified Level Mapping ...................................................................... 1

Appendix D ENERGY STAR Version 2.0 Mapping....................................................................... D.1

Appendix E ENERGY STAR Version 2.5 Mapping …….....................................................................

Appendix F ENERGY STAR Version 3.0 Mapping …........................................................................

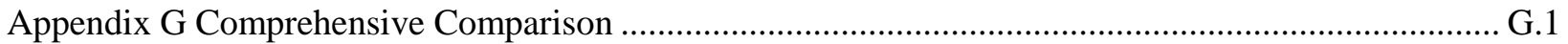


Appendix A

\section{Mapping Summary}




\begin{tabular}{|c|c|c|c|c|c|}
\hline Mapping Existing Systems to IECC 2009 & & \multirow[b]{2}{*}{ 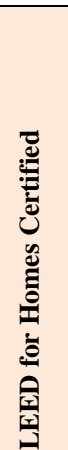 } & \multirow[b]{2}{*}{ 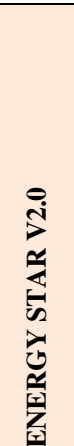 } & \multirow[b]{2}{*}{ 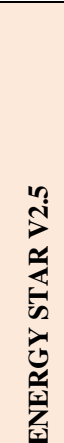 } & \multirow[b]{2}{*}{ 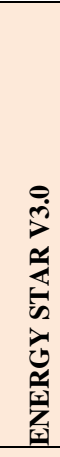 } \\
\hline $\begin{array}{ll}\text { Exceeds the Requirements } \\
\text { Specifies the same requirements } \\
\text { Specifies partial requirements } \\
\text { NM Similar topics, but not required (may be optional) } \\
\text { Not mentioned in the document } \\
\text { No requirement in this section of the rating system }\end{array}$ & 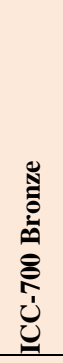 & & & & \\
\hline \multicolumn{6}{|l|}{ Energy Efficiency - Residential } \\
\hline \multicolumn{6}{|l|}{ Building Thermal Envelope (402) } \\
\hline \multicolumn{6}{|l|}{402.1 General (Prescriptive). } \\
\hline 402.1.1 Insulation and fenestration criteria. & NA & & & $\bigcirc$ & \\
\hline 402.1.2 R-value computation. & NA & & NA & $\bigcirc$ & \\
\hline 402.1.3 U-factor alternative. & NA & 0 & O & $\bigcirc$ & \\
\hline 402.1.4 Total UA alternative. & $\bigcirc$ & 0 & 0 & $\bigcirc$ & \\
\hline \multicolumn{6}{|l|}{ 402.2 Specific insulation requirements (Prescriptive). } \\
\hline 402.2.1 Ceilings with attic spaces. & NA & & & $\bigcirc$ & \\
\hline 402.2.2 Ceilings without attic spaces. & NA & & & $\bigcirc$ & \\
\hline 402.2.3 Access hatches and doors. & 0 & NM & & $\bigcirc$ & \\
\hline 402.2.4 Mass walls & & & & $\bigcirc$ & \\
\hline 402.2.5 Steel-frame ceilings, walls, and floors. & NA & & & $\bigcirc$ & \\
\hline 402.2.6 Floors. & & & & $\bigcirc$ & \\
\hline 402.2.7 Basement walls. & $\bigcirc$ & & & $\bigcirc$ & \\
\hline 402.2.8 Slab-on-grade floors. & NM & & & $\bigcirc$ & \\
\hline 402.2.9 Crawl space walls. & O & & & $\bigcirc$ & \\
\hline 402.2.10 Masonry veneer. & NM & 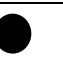 & & $\bigcirc$ & \\
\hline 402.2.11 Thermally isolated sunroom insulation. & NM & 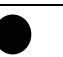 & & $\bigcirc$ & \\
\hline \multicolumn{6}{|l|}{ 402.3 Fenestration (Prescriptive). } \\
\hline 402.3.1 U-factor. & 0 & NM & & $\bigcirc$ & \\
\hline 402.3.2-402.3.3. & O & 0 & 0 & $\mathrm{O}$ & \\
\hline 402.3.4 Opaque door exemption. & NA & NM & 0 & $\bigcirc$ & \\
\hline 402.3.5 Thermally isolated sunroom U-factor. & NM & NM & NM & O & \\
\hline 402.3.6 Replacement fenestration. & 0 & NM & NM & $\bigcirc$ & \\
\hline
\end{tabular}




\begin{tabular}{|c|c|c|c|c|c|}
\hline \multicolumn{6}{|l|}{ 402.4 Air leakage (Mandatory). } \\
\hline 402.4.1 Building thermal envelope. & & NM & & & \\
\hline \multicolumn{6}{|l|}{ 402.4.2 Air sealing and insulation. } \\
\hline 402.4.3 Fireplaces. & & & NM & NM & NM \\
\hline 402.4.4 Fenestration air leakage. & NM & NM & & & \\
\hline 402.4.5 Recessed lighting. & & NM & & & \\
\hline 402.5 Maximum fenestration U-factor and SHGC (Mandatory). & & NM & NM & & \\
\hline \multicolumn{6}{|l|}{ Systems (403) } \\
\hline \multicolumn{6}{|l|}{403.1 Controls (Mandatory). } \\
\hline \multicolumn{6}{|l|}{ 403.1.1 Programmable thermostat. } \\
\hline 403.1.2 Heat pump supplementary heat. & & & NM & & \\
\hline \multicolumn{6}{|l|}{403.2 Ducts. } \\
\hline \multicolumn{6}{|l|}{ 403.2.1 Insulation (Prescriptive). } \\
\hline \multicolumn{6}{|l|}{ 403.2.2 Sealing (Mandatory). } \\
\hline \multicolumn{6}{|l|}{ 403.2.3 Building cavities (Mandatory). } \\
\hline 403.3 Mechanical system piping insulation (Mandatory). & NM & & NM & NM & NM \\
\hline 403.4 Circulating hot water systems (Mandatory). & & & & NM & NM \\
\hline 403.5 Mechanical ventilation (Mandatory). & NM & NM & & NM & NM \\
\hline \multicolumn{6}{|l|}{ 403.6 Equipment sizing (Mandatory). } \\
\hline 403.7 Systems serving multiple dwelling units (Mandatory). & NA & NA & NA & NA & NA \\
\hline 403.8 Snow melt system controls (Mandatory). & NM & NM & NM & NM & NM \\
\hline \multicolumn{6}{|l|}{ 403.9 Pools (Mandatory). } \\
\hline 403.9.1 Pool heaters. & NM & NM & NM & NM & NM \\
\hline 403.9.2 Time switches. & NM & NM & NM & NM & NM \\
\hline 403.9.3 Pool covers. & NM & NM & NM & NM & NM \\
\hline \multicolumn{6}{|l|}{ Electrical Power and Lighting (404) } \\
\hline \multicolumn{6}{|l|}{ 404.1 Lighting equipment (Prescriptive). } \\
\hline \multicolumn{6}{|l|}{ Simulated Performance Alternative (405) } \\
\hline 405.2 Mandatory requirements. & & & NM & & \\
\hline 405.3 Performance-based compliance. & & 0 & 0 & 0 & 0 \\
\hline 405.4 Documentation. & & NM & NM & NM & NM \\
\hline 405.5 Calculation procedure. & & NM & NM & NM & NM \\
\hline 405.6 Calculation software tools. & & NM & NM & NM & NM \\
\hline
\end{tabular}


Appendix B

\section{ICC-700 Bronze Level Mapping}




\begin{tabular}{|c|c|c|c|c|}
\hline $\begin{array}{l}\text { Requirement } \\
\text { Category }\end{array}$ & $\begin{array}{l}\text { IECC Requirement } \\
\text { Reference }\end{array}$ & IECC 2009 & ICC-700 & Comments \\
\hline Prescriptive & $\begin{array}{l}\text { 402.1.1 Insulation and } \\
\text { fenestration criteria. }\end{array}$ & $\begin{array}{l}\text { The building thermal envelope shall meet the } \\
\text { requirements of Table } 402.1 .1 \text { based on the } \\
\text { climate zone specified in Chapter } 3 \text {. }\end{array}$ & $\begin{array}{l}\text { See alternative compliance path under } 2009 \text { IECC } \\
\text { section 402.1.4. }\end{array}$ & $\begin{array}{l}\text { ICC } 700 \text { does not require specific insulation } R \text { - } \\
\text { values: ICC } 700 \text { awards optional points under } \\
\text { the alternative UA path (see below description } \\
\text { under Section 402.1.4). }\end{array}$ \\
\hline Prescriptive & $\begin{array}{l}\text { 402.1.2 R-value } \\
\text { computation. }\end{array}$ & $\begin{array}{l}\text { Insulation material used in layers, such as } \\
\text { framing cavity insulation and insulating } \\
\text { sheathing, shall be summed to compute the } \\
\text { component R-value. The manufacturer's settled } \\
\text { R-value shall be used for blown insulation. } \\
\text { Computed R-values shall not include an R-value } \\
\text { for other building materials or air films. }\end{array}$ & $\begin{array}{l}\text { See alternative compliance path under } 2009 \text { IECC } \\
\text { section 402.1.4. }\end{array}$ & $\begin{array}{l}\text { ICC } 700 \text { does not require specific insulation } R \text { - } \\
\text { values: ICC } 700 \text { awards optional points under } \\
\text { the alternative UA path (see below description } \\
\text { under Section 402.1.4). }\end{array}$ \\
\hline Prescriptive & $\begin{array}{l}\text { 402.1.3 U-factor } \\
\text { alternative. }\end{array}$ & $\begin{array}{l}\text { An assembly with a U-factor equal to or less } \\
\text { than that specified in Table } 402.1 .3 \text { shall be } \\
\text { permitted as an alternative to the R-value in } \\
\text { Table 402.1.1. }\end{array}$ & $\begin{array}{l}\text { See alternative compliance path under } 2009 \text { IECC } \\
\text { section 402.1.4. }\end{array}$ & $\begin{array}{l}\text { ICC } 700 \text { does not require specific assembly U- } \\
\text { factor: ICC } 700 \text { awards optional points under } \\
\text { the alternative UA path (see below description } \\
\text { under Section 402.1.4). }\end{array}$ \\
\hline Prescriptive & $\begin{array}{l}\text { 402.1.4 Total UA } \\
\text { alternative. }\end{array}$ & $\begin{array}{l}\text { If the total building thermal envelope UA... is } \\
\text { less than or equal to the total UA resulting from } \\
\text { using the U-factors in Table } 402.1 .3 \ldots . . \text {, the } \\
\text { building shall be considered in compliance with } \\
\text { Table } 402.1 .1 \text {. The UA calculation shall be done } \\
\text { using a method consistent with the ASHRAE } \\
\text { Handbook of Fundamentals and shall include the } \\
\text { thermal bridging effects of framing materials. } \\
\text { The SHGC requirements shall be met in addition } \\
\text { to the UA compliance. }\end{array}$ & $\begin{array}{l}\text { 703.1 Building Envelope } \\
703.1 .1 \text { (Optional, Prescriptive path) Where the } \\
\text { total building thermal envelope UA is less than } \\
\text { required by the } 2006 \text { IECC Section } 402.1 .4 \text {, the } \\
\text { total building thermal envelope UA is in } \\
\text { accordance with Table } 703.1 .1 \text {. Where insulation } \\
\text { is used to achieve these percentages, a third-party } \\
\text { grading of the installation as achieving Grade } 1 \text { is } \\
\text { required. }\end{array}$ & $\begin{array}{l}\text { Optional - If the prescriptive path is chosen, } \\
\text { and the maximum ICC } 700 \text { points are achieved } \\
\text { ( } 20 \% \text { improvement) the } 2009 \text { IECC } \\
\text { requirement is met. This is an alternative to } \\
\text { IECC Section 402.1.1. }\end{array}$ \\
\hline Prescriptive & $\begin{array}{l}\text { 402.2 Specific } \\
\text { insulation } \\
\text { requirements. 402.2.1 } \\
\text { Ceilings with attic } \\
\text { spaces. }\end{array}$ & $\begin{array}{l}\text { When Section } 402.1 .1 \text { would require R-38 in the } \\
\text { ceiling, R-30 shall be deemed to satisfy the } \\
\text { requirement for R-38 whenever the full height of } \\
\text { uncompressed R-30 insulation extends over the } \\
\text { wall top plate at the eaves. Similarly, R-38 shall } \\
\text { be deemed to satisfy the requirements for R-49 } \\
\text { where ever the full height of uncompressed R-38 } \\
\text { insulation extends over the top plate at the eaves. } \\
\text { This reduction shall not apply to the U-factor } \\
\text { alternative approach in Section } 402.1 .3 \text { and the } \\
\text { total UA alternative in Section } 402.1 .4 \text {. }\end{array}$ & $\begin{array}{l}\text { See alternative compliance path under } 2009 \text { IECC } \\
\text { section 402.1.4. }\end{array}$ & $\begin{array}{l}\text { ICC } 700 \text { does not require specific insulation } R- \\
\text { values: ICC } 700 \text { awards optional points under } \\
\text { the alternative UA path (see below description } \\
\text { under Section 402.1.4). }\end{array}$ \\
\hline Prescriptive & $\begin{array}{l}\text { 402.2 Specific } \\
\text { insulation } \\
\text { requirements. } 402.2 .2 \\
\text { Ceilings without attic } \\
\text { spaces. }\end{array}$ & $\begin{array}{l}\text { Where Section } 402.1 .1 \text { would require insulation } \\
\text { levels above R-30 and the design often } \\
\text { roof/ceiling assemble does not allow sufficient } \\
\text { space for the required insulation, the minimum } \\
\text { required insulation for such roof/ceiling } \\
\text { assemblies shall be R-30. This reduction of } \\
\text { insulation from the requirements of Section } \\
402.1 .1 \text { shall be limited to } 500 \text { square feet of } 20 \\
\text { percent of the total insulated ceiling area, } \\
\text { whichever is less. This reduction shall not apply } \\
\text { to the U-factor alternative approach in Section }\end{array}$ & $\begin{array}{l}\text { See alternative compliance path under } 2009 \text { IECC } \\
\text { section 402.1.4. }\end{array}$ & $\begin{array}{l}\text { ICC } 700 \text { does not require specific insulation } R \text { - } \\
\text { values: ICC } 700 \text { awards optional points under } \\
\text { the alternative UA path (see below description } \\
\text { under Section 402.1.4). }\end{array}$ \\
\hline
\end{tabular}




\begin{tabular}{|c|c|c|c|c|}
\hline $\begin{array}{l}\text { Requirement } \\
\text { Category }\end{array}$ & $\begin{array}{l}\text { IECC Requirement } \\
\text { Reference }\end{array}$ & IECC 2009 & ICC-700 & Comments \\
\hline & & $\begin{array}{l}\text { 402.1.3 and the total UA alternative in Section 4- } \\
\text { 2.1.4. }\end{array}$ & & \\
\hline Prescriptive & $\begin{array}{l}\text { 402.2 Specific } \\
\text { insulation } \\
\text { requirements. 402.2.3 } \\
\text { Access hatches and } \\
\text { doors. }\end{array}$ & $\begin{array}{l}\text { Access doors from conditioned spaces to } \\
\text { unconditioned spaces (e.g., attics and crawl } \\
\text { spaces) shall be weatherstripped and insulated to } \\
\text { a level equivalent to the insulation on the } \\
\text { surrounding surfaces. Access shall be provided } \\
\text { to all equipment that prevents damaging or } \\
\text { compressing the insulation. A wood framed or } \\
\text { equivalent baffle or retainer is required to be } \\
\text { provided when loose fill insulation is installed, } \\
\text { the purpose of which is to prevent the loose fill } \\
\text { insulation from spilling into the living space } \\
\text { when the attic access is opened, and to provide a } \\
\text { permanent means of maintaining the installed R- } \\
\text { value of the loose fill insulation. }\end{array}$ & $\begin{array}{l}\text { Section 701.4.3.4 Ceilings and attics. (1) Attic } \\
\text { Access (except unvented attics). (Mandatory) } \\
\text { Attic access, knee wall door, or drop-down stair is } \\
\text { covered with insulation and gasketed. }\end{array}$ & $\begin{array}{l}\text { ICC } 700 \text { does not fully meet the } 2009 \text { IECC } \\
\text { requirement. It does not specify that attic } \\
\text { access must be insulated to the same R-value } \\
\text { as the surrounding assemblies. }\end{array}$ \\
\hline Prescriptive & $\begin{array}{l}\text { 402.2 Specific } \\
\text { insulation } \\
\text { requirements. } 402.2 .4 \\
\text { Mass walls. }\end{array}$ & $\begin{array}{l}\text { Mass walls for the purposes of this chapter shall } \\
\text { be considered above-grade walls of concrete } \\
\text { block, concrete, insulated concrete form (ICF), } \\
\text { masonry cavity, brick (other than brick veneer), } \\
\text { earth (adobe, compressed earth block, rammed } \\
\text { earth) and solid timber/logs. }\end{array}$ & $\begin{array}{l}\text { Section } 202 \text { - Definitions } \\
\text { Mass Walls. Walls constructed of concrete block, } \\
\text { concrete, insulated concrete form (ICF), masonry } \\
\text { cavity, brick, earth (adobe, compressed earth } \\
\text { block, rammed earth), and/or solid timber/logs, } \\
\text { with a minimum of } 50 \text { percent of the required R- } \\
\text { value on the exterior of the wall. }\end{array}$ & $\begin{array}{l}\text { The ICC } 700 \text { requirement meets the } 2009 \text { IECC } \\
\text { requirement. }\end{array}$ \\
\hline Prescriptive & $\begin{array}{l}402.2 \text { Specific } \\
\text { insulation } \\
\text { requirements. 402.2.5 } \\
\text { Steel-frame ceilings, } \\
\text { walls, and floors. }\end{array}$ & $\begin{array}{l}\text { Steel-frame ceilings, walls and floors shall meet } \\
\text { the insulation requirements of Table } 402.2 .5 \text { or } \\
\text { shall meet the U-factor requirements in Table } \\
402.1 .3 \text {. The calculation of the U-factor for a } \\
\text { steel-frame envelope assembly shall use a series- } \\
\text { parallel path calculation method. } \\
\text { Exception: In Climate Zones } 1 \text { and } 2 \text {, the } \\
\text { continuous insulation requirements in Table } \\
402.2 .5 \text { shall be permitted to be reduced to R-3 } \\
\text { for steel frame wall assemblies with studs spaced } \\
\text { at } 24 \text { inches }(610 \mathrm{~mm}) \text { on center. }\end{array}$ & $\begin{array}{l}\text { See alternative compliance path under } 2009 \text { IECC } \\
\text { section 402.1.4. }\end{array}$ & $\begin{array}{l}\text { ICC } 700 \text { does not require specific insulation } R \text { - } \\
\text { values: ICC } 700 \text { awards optional points under } \\
\text { the alternative UA path (see description under } \\
\text { Section 402.1.4). }\end{array}$ \\
\hline Prescriptive & $\begin{array}{l}\text { 402.2 Specific } \\
\text { insulation } \\
\text { requirements. } 402.2 .6 \\
\text { Floors. }\end{array}$ & $\begin{array}{l}\text { Floor insulation shall be installed to maintain } \\
\text { permanent contact with the underside of the } \\
\text { subfloor decking. }\end{array}$ & $\begin{array}{l}\text { 701.4.3.2 Floors, foundations, and crawlspaces } \\
\text { (Mandatory) } \\
\text { (1) Floors. (including insulated floors above } \\
\text { garages and cantilevered floors) } \\
\text { (a) Insulation is installed to maintain permanent } \\
\text { contact with the underside of the subfloor } \\
\text { decking, enveloping any attached ductwork within } \\
\text { the thermal envelope without compression or air } \\
\text { gaps in the insulation. This practice does not } \\
\text { apply to ducts or other mechanical equipment that } \\
\text { is adjacent to the underside of the subfloor. } \\
\text { (b) Batt and loose-fill insulation is held in place } \\
\text { by permanent attachments or systems in }\end{array}$ & $\begin{array}{l}\text { Mandatory - ICC } 700 \text { requirement meets the } \\
2009 \text { IECC requirement. }\end{array}$ \\
\hline
\end{tabular}




\begin{tabular}{|c|c|c|c|c|}
\hline $\begin{array}{c}\text { Requirement } \\
\text { Category }\end{array}$ & $\begin{array}{c}\text { IECC Requirement } \\
\text { Reference }\end{array}$ & IECC 2009 & ICC-700 & Comments \\
\hline & & & accordance with the manufacturer's instructions. & \\
\hline Prescriptive & $\begin{array}{l}\text { 402.2 Specific } \\
\text { insulation } \\
\text { requirements. 402.2.7 } \\
\text { Basement walls. }\end{array}$ & $\begin{array}{l}\text { Walls associated with conditioned basements } \\
\text { shall be insulated from the top of the basement } \\
\text { wall down to } 10 \text { feet ( } 3048 \mathrm{~mm} \text { ) below grade or } \\
\text { to the basement floor, whichever is less. Walls } \\
\text { associated with unconditioned basements shall } \\
\text { meet this requirement unless the floor overhead } \\
\text { is insulated in accordance with Sections } 402.1 .1 \\
\text { and } 402.2 .6 \text {. }\end{array}$ & $\begin{array}{l}\text { 703.1 Building Envelope (Optional, } \\
\text { Prescriptive path) } \\
703.1 .2 \text { The insulation installation is graded by a } \\
\text { third party and is in accordance with Sections } \\
703.1 .2 .1,703.1 .2 .2,703.1 .2 .3 \text {, and/or } 703.1 .2 .4 \\
\text { as applicable. (Points not awarded in this section } \\
\text { if already awarded under Section } 703.1 .1 \text { ) } \\
703.1 .2 .2 \text { Grade } 1 \text { installation is in accordance } \\
\text { with the following: } \\
\text { (1) Insulation uniformly fills each cavity side-to- } \\
\text { side and top-to-bottom, without substantial gaps } \\
\text { or voids around obstructions (such as blocking or } \\
\text { bridging). } \\
\text { (8) Grade } 1 \text { insulation meets or exceeds all } \\
\text { requirements for Grade } 2 \text { insulation. } \\
703.1 .2 .3 \text { Grade } 2 \text { insulation is in accordance with } \\
\text { the following: } \\
\text { (2) In conditioned basements or crawlspaces the } \\
\text { following apply: } \\
\text { (a) insulation is installed in complete contact with } \\
\text { the subfloor surfaces. } \\
\text { (b) floor insulation over vented or ambient } \\
\text { conditions is enclosed on six sides. } \\
\text { (3) Floor insulation over unconditioned basements } \\
\text { is not required to be enclosed on six sides. }\end{array}$ & $\begin{array}{l}\text { Optional - If points for Grade } 1 \text { insulation are } \\
\text { achieved, IECC requirement will be met. ICC } \\
700 \text { requires uniform insulation from top-to- } \\
\text { bottom of cavities, which is more stringent that } \\
2009 \text { IECC requirement to be insulated from } \\
\text { top of the basement wall down to } 10 \text { feet below } \\
\text { grade or to the basement floor, whichever is } \\
\text { less. } \\
\text { If points for Grade } 2 \text { insulation are achieved, } \\
2009 \text { IECC requirement will not be met } \\
\text { because Grade } 2 \text { insulation does not require } \\
\text { wall insulation in conditioned basements. }\end{array}$ \\
\hline Prescriptive & $\begin{array}{l}\text { 402.2 Specific } \\
\text { insulation } \\
\text { requirements. } 402.2 .8 \\
\text { Slab-on-grade floors. }\end{array}$ & $\begin{array}{l}\text { Slab-on-grade floors with a floor surface less } \\
\text { than } 12 \text { inches ( } 305 \mathrm{~mm} \text { ) below grade shall be } \\
\text { insulated in accordance with Table } 402.1 .1 \text {. The } \\
\text { insulation shall extend downward from the top of } \\
\text { the slab on the outside or inside of the } \\
\text { foundation wall. Insulation located below grade } \\
\text { shall be extended the distance provided in Table } \\
402.1 .1 \text { by any combination of vertical } \\
\text { insulation, insulation extending under the slab or } \\
\text { insulation extending out from the building. } \\
\text { Insulation extending away from the building } \\
\text { shall be protected by pavement or by a minimum } \\
\text { of } 10 \text { inches ( } 254 \text { mm) of soil. The top edge of } \\
\text { the insulation installed between the exterior wall } \\
\text { and the edge of the interior slab shall be } \\
\text { permitted to be cut at a } 45-\text { degree ( } 0.79 \text { rad) } \\
\text { angle away from the exterior wall. Slab-edge } \\
\text { insulation is not required in jurisdictions } \\
\text { designated by the code official as having a very } \\
\text { heavy termite infestation. }\end{array}$ & - & Not explicitly mentioned in ICC 700. \\
\hline Prescriptive & 402.2 Specific & As an alternative to insulating floors over crawl & 701.4.3 Insulation and air sealing (Mandatory) & Mandatory - ICC 700 requirement meets the \\
\hline
\end{tabular}




\begin{tabular}{|c|c|c|c|c|}
\hline $\begin{array}{c}\text { Requirement } \\
\text { Category }\end{array}$ & $\begin{array}{c}\text { IECC Requirement } \\
\text { Reference }\end{array}$ & IECC 2009 & ICC-700 & Comments \\
\hline & $\begin{array}{l}\text { insulation } \\
\text { requirements. } 402.2 .9 \\
\text { Crawl space walls. }\end{array}$ & $\begin{array}{l}\text { spaces, crawl space walls shall be permitted to be } \\
\text { insulated when the crawl space is not vented to } \\
\text { the outside. Crawl space wall insulation shall be } \\
\text { permanently fastened to the wall and extend } \\
\text { downward from the floor to the finished grade } \\
\text { level and then vertically and/or horizontally for } \\
\text { at least an additional } 24 \text { inches ( } 610 \mathrm{~mm}) \text {. } \\
\text { Exposed earth in unvented crawl space } \\
\text { foundations shall be covered with a continuous } \\
\text { Class I vapor retarder in accordance with the } \\
\text { International Building Code. All joints of the } \\
\text { vapor retarder shall overlap by } 6 \text { inches ( } 153 \\
\text { mm) and be sealed or taped. The edges of the } \\
\text { vapor retarder shall extend at least } 6 \text { inches ( } 153 \\
\text { mm) up the stem wall and shall be attached to } \\
\text { the stem wall. }\end{array}$ & $\begin{array}{l}\text { (2) Crawlspace. Where insulated, crawlspace wall } \\
\text { insulation is permanently attached to the walls. } \\
\text { Exposed earth in unvented crawlspaces is covered } \\
\text { with continuous vapor retarder with overlapping } \\
\text { joints that are taped or masticed. }\end{array}$ & 2009 IECC requirement. \\
\hline Prescriptive & $\begin{array}{l}\text { 402.2 Specific } \\
\text { insulation } \\
\text { requirements. } \\
\text { 402.2.10 Masonry } \\
\text { veneer. }\end{array}$ & $\begin{array}{l}\text { Insulation shall not be required on the horizontal } \\
\text { portion of the foundation that supports a } \\
\text { masonry veneer. }\end{array}$ & - & Not explicitly mentioned in ICC 700. \\
\hline Prescriptive & $\begin{array}{l}\text { 402.2 Specific } \\
\text { insulation } \\
\text { requirements. } \\
\text { 402.2.11 Thermally } \\
\text { isolated sunroom } \\
\text { insulation. } \\
\end{array}$ & $\begin{array}{l}\text { The minimum ceiling insulation R-values shall } \\
\text { be R-19 in Zones } 1 \text { through } 4 \text { and R-24 in Zones } \\
5 \text { through } 8 \text {. The minimum wall R-value shall be } \\
\text { R-13 in all zones. New wall(s) separating a } \\
\text { sunroom from conditioned space shall meet the } \\
\text { building thermal envelope requirements. }\end{array}$ & e & Not explicitly mentioned in ICC 700. \\
\hline Prescriptive & $\begin{array}{l}\text { 402.3 Fenestration. } \\
\text { 402.3.1 U-factor. }\end{array}$ & $\begin{array}{l}\text { An area-weighted average of fenestration } \\
\text { products shall be permitted to satisfy the U- } \\
\text { factor requirements. }\end{array}$ & $\begin{array}{l}\text { 701.4.4 Fenestration (Mandatory) } \\
\text { 701.4.4.1 NFRC-certified U-factor and SHGC } \\
\text { windows, exterior doors, skylights, and tubular } \\
\text { daylighting devices (TDDs) are in accordance } \\
\text { with ENERGY STAR, or equivalent, or Table } \\
\text { 701.4.4.1. Decorative fenestration elements with } \\
\text { a maximum area of } 15 \text { square feet or } 10 \text { percent of } \\
\text { the total glazing area, whichever is less, are not } \\
\text { required to comply with this practice. } \\
\text { 703.3 Fenestration (Optional, Prescriptive } \\
\text { path) } \\
\text { 703.3.1 The NFRC-certified (or equivalent) U- } \\
\text { factor and SHGC for windows...are in accordance } \\
\text { with Table 703.3.1(a) or (b)... }\end{array}$ & $\begin{array}{l}\text { ICC 700 Table 701.4.4.1, 703.3.1(a), and } \\
\text { 703.3.1(b) specify U-factors, which is similar } \\
\text { but not identical to the IECC 2009 } \\
\text { requirement. The ICC } 700 \text { Mandatory U- } \\
\text { factors for Zone } 3 \text { do not meet the IECC } 2009 \\
\text { values in Table 402.1.1 and 402.1.3. }\end{array}$ \\
\hline Prescriptive & $\begin{array}{l}\text { 402.3 Fenestration. } \\
\text { 402.3.2-402.3.3. }\end{array}$ & $\begin{array}{l}\text { 402.3.2 Glazed fenestration SHGC. An area- } \\
\text { weighted average of fenestration products more } \\
\text { than } 50 \text { percent glazed shall be permitted to } \\
\text { satisfy the SHGC requirements. } \\
\text { 402.3.3 Glazed fenestration exemption. Up to } 15 \\
\text { square feet }(1.4 \mathrm{~m} 2) \text { of glazed fenestration per }\end{array}$ & $\begin{array}{l}\text { 701.4.4.1 (Mandatory) } \\
\text {...Decorative fenestration elements with a } \\
\text { maximum area of } 15 \text { square feet or } 10 \text { percent of } \\
\text { the total glazing area, whichever is less, are not } \\
\text { required to comply with this practice. } \\
\text { 703.3.1. (Optional)...Decorative fenestration }\end{array}$ & $\begin{array}{l}\text { Mandatory - ICC } 700 \text { requirement meets the } \\
2009 \text { IECC requirement: ICC } 700 \text { allows the } \\
\text { same exemption as } 2009 \text { IECC. }\end{array}$ \\
\hline
\end{tabular}




\begin{tabular}{|c|c|c|c|c|}
\hline $\begin{array}{c}\text { Requirement } \\
\text { Category }\end{array}$ & $\begin{array}{c}\text { IECC Requirement } \\
\text { Reference }\end{array}$ & IECC 2009 & ICC-700 & Comments \\
\hline & & $\begin{array}{l}\text { dwelling unit shall be permitted to be exempt } \\
\text { from U-factor and SHGC requirements in } \\
\text { Section } 402.1 .1 \text {. This exemption shall not apply } \\
\text { to the U-factor alternative approach in Section } \\
\text { 402.1.3 and the Total UA alternative in Section } \\
\text { 402.1.4. }\end{array}$ & $\begin{array}{l}\text { elements with a maximum area of } 15 \text { square feet } \\
\text { or } 10 \text { percent of the total glazing area, whichever } \\
\text { is less, are not required to comply with this } \\
\text { practice. }\end{array}$ & \\
\hline Prescriptive & $\begin{array}{l}\text { 402.3 Fenestration. } \\
\text { 402.3.4 Opaque door } \\
\text { exemption. }\end{array}$ & $\begin{array}{l}\text { One side-hinged opaque door assembly up to } 24 \\
\text { square feet }(2.22 \mathrm{~m} 2) \text { in area is exempted from } \\
\text { the U-factor requirement in Section } 402.1 .1 \text {. } \\
\text { This exemption shall not apply to the U-factor } \\
\text { alternative approach in Section } 402.1 .3 \text { and the } \\
\text { total UA alternative in Section 402.1.4. }\end{array}$ & - & $\begin{array}{l}\text { ICC } 700 \text { section } 703.1 \text { complies with the total } \\
\text { UA alternative approach in } 2009 \text { IECC } \\
\text { 402.1.4, thus the exemption does not apply. }\end{array}$ \\
\hline Prescriptive & $\begin{array}{l}\text { 402.3 Fenestration. } \\
\text { 402.3.5 Thermally } \\
\text { isolated sunroom U- } \\
\text { factor. }\end{array}$ & $\begin{array}{l}\text { For Zones } 4 \text { through } 8 \text {, the maximum } \\
\text { fenestration U-factor shall be } 0.50 \text { and the } \\
\text { maximum skylight U-factor shall be } 0.75 . \mathrm{New} \\
\text { windows and doors separating the sunroom from } \\
\text { conditioned space shall meet the building } \\
\text { thermal envelope requirements. }\end{array}$ & - & Not explicitly mentioned in ICC 700. \\
\hline Mandatory & $\begin{array}{l}\text { 402.4 Air leakage. } \\
\text { 402.4.1 Building } \\
\text { thermal envelope. }\end{array}$ & $\begin{array}{l}\text { The building thermal envelope shall be durably } \\
\text { sealed to limit infiltration. The sealing methods } \\
\text { between dissimilar materials shall allow for } \\
\text { differential expansion and contraction. The } \\
\text { following shall be caulked, gasketed, } \\
\text { weatherstripped or otherwise sealed with an air } \\
\text { barrier material, suitable film or solid material: }\end{array}$ & - & General guidance - not a unique requirement. \\
\hline Mandatory & $\begin{array}{l}\text { 402.4 Air leakage. } \\
\text { 402.4.1 Building } \\
\text { thermal envelope. (1) }\end{array}$ & $\begin{array}{l}\text { The following shall be caulked, gasketed, } \\
\text { weatherstripped or otherwise sealed with an air } \\
\text { barrier material, suitable film or solid material: } \\
\text { 1. All joints, seams and penetrations. }\end{array}$ & $\begin{array}{l}\text { 701.4.3 Insulation and air sealing (Mandatory). } \\
\text { 701.4.3.1 General. Insulation and air sealing is in } \\
\text { accordance with the following: } \\
\text { (1) Insulation. Insulation is installed in } \\
\text { accordance with the manufacturer's instructions or } \\
\text { local code, as applicable. } \\
\text { (2) Shafts (duct shaft, piping shaft/penetrations, } \\
\text { flue shaft). Openings to unconditioned space are } \\
\text { fully sealed with solid blocking or flashing and } \\
\text { any remaining gaps are sealed with caulk or foam. } \\
\text { Fire-rated collars and caulking are installed where } \\
\text { required. } \\
\text { 703.2.1.2 Air Barriers (Optional, Prescriptive } \\
\text { path). Air barrier is installed at any exterior edge }\end{array}$ & $\begin{array}{l}\text { Mandatory - ICC } 700 \text { requirement meets the } \\
2009 \text { IECC requirement. }\end{array}$ \\
\hline
\end{tabular}




\begin{tabular}{|c|c|c|c|c|}
\hline $\begin{array}{c}\text { Requirement } \\
\text { Category }\end{array}$ & $\begin{array}{l}\text { IECC Requirement } \\
\text { Reference }\end{array}$ & IECC 2009 & ICC-700 & Comments \\
\hline & & & $\begin{array}{l}\text { of insulation at floors, foundations, and } \\
\text { crawlspaces including insulated floors above } \\
\text { garages and cantilevered floors. }\end{array}$ & \\
\hline Mandatory & $\begin{array}{l}\text { 402.4 Air leakage. } \\
\text { 402.4.1 Building } \\
\text { thermal envelope. (2) }\end{array}$ & $\begin{array}{l}\text { The following shall be caulked, gasketed, } \\
\text { weatherstripped or otherwise sealed with an air } \\
\text { barrier material, suitable film or solid material: } \\
\text { 2. Site-built windows, doors and skylights. }\end{array}$ & $\begin{array}{l}\text { 701.4.3 Insulation and air sealing (Mandatory). } \\
\text { 701.4.3.3 Walls } \\
\text { (1) Windows and doors. Caulking, gasketing, } \\
\text { adhesive flashing tape, foam sealant, or } \\
\text { weatherstripping is installed forming a complete } \\
\text { air barrier. } \\
\text { (4) Skylights and knee walls. Skylight shafts and } \\
\text { knee walls are insulated to the same level as the } \\
\text { exterior walls. } \\
\text { 703.2 Insulation and air sealing (Optional, } \\
\text { Prescriptive path). } \\
\text { 703.2.1.3 Walls } \\
\text { (4) Skylight shafts and knee walls are air sealed. } \\
\text { Insulation on attic knee walls and skylight shafts } \\
\text { are physically supported by stapling in place, } \\
\text { netting, or using other mechanical attachment. }\end{array}$ & $\begin{array}{l}\text { Mandatory - ICC } 700 \text { requirement for doors } \\
\text { and windows meets the } 2009 \text { IECC } \\
\text { requirement. } \\
\text { Mandatory ICC } 700 \text { points for skylights cover } \\
\text { insulation levels. Optional ICC } 700 \text { points for } \\
\text { skylights cover air barriers. If the optional } \\
\text { points are achieved, all IECC requirements } \\
\text { will be met. }\end{array}$ \\
\hline Mandatory & $\begin{array}{l}\text { 402.4 Air leakage. } \\
\text { 402.4.1 Building } \\
\text { thermal envelope. (3) }\end{array}$ & $\begin{array}{l}\text { The following shall be caulked, gasketed, } \\
\text { weatherstripped or otherwise sealed with an air } \\
\text { barrier material, suitable film or solid material: } \\
\text { 3. Openings between window and door } \\
\text { assemblies and their respective jambs and } \\
\text { framing. }\end{array}$ & $\begin{array}{l}\text { 701.4.3 Insulation and air sealing (Mandatory). } \\
\text { 701.4.3.3 Walls } \\
\text { (1) Windows and doors. Caulking, gasketing, } \\
\text { adhesive flashing tape, foam sealant, or } \\
\text { weatherstripping is installed forming a complete } \\
\text { air barrier. }\end{array}$ & $\begin{array}{l}\text { Mandatory - ICC } 700 \text { requirement meets the } \\
2009 \text { IECC requirement. }\end{array}$ \\
\hline Mandatory & $\begin{array}{l}\text { 402.4 Air leakage. } \\
\text { 402.4.1 Building } \\
\text { thermal envelope. (4) }\end{array}$ & $\begin{array}{l}\text { The following shall be caulked, gasketed, } \\
\text { weatherstripped or otherwise sealed with an air } \\
\text { barrier material, suitable film or solid material: } \\
\text { 4. Utility penetrations. }\end{array}$ & $\begin{array}{l}\text { 703.2 Insulation and air sealing (Optional, } \\
\text { Prescriptive path). } \\
\text { 703.2.1.1.2 Plumbing and wiring } \\
\text { (1) At a minimum, insulation is placed between } \\
\text { the outside (ceiling, wall, or floor) and the pipes. } \\
\text { (2) Batt insulation is split or cut to fit around } \\
\text { wiring and plumbing. } \\
\text { (3) Sprayed insulation is installed to encapsulate } \\
\text { pipes where the pipe temperature is } 180 \text { egress F } \\
\text { (82.2 C) or less. Wiring is fastened in place to } \\
\text { prevent displacement prior to spraying. } \\
\text { 703.2.1.3 Walls } \\
\text { (2) Air-sealed-type electrical outlet boxes are } \\
\text { installed or the air barrier extends completely } \\
\text { behind the boxes. Insulation is placed between } \\
\text { the sheathing and the rear of the electrical or } \\
\text { phone boxes located on exterior walls. Electrical } \\
\text { outlet boxes are covered prior to spraying } \\
\text { insulation. }\end{array}$ & $\begin{array}{l}\text { Optional - if the ICC } 700 \text { points are achieved } \\
\text { the } 2009 \text { IECC requirement will be met. }\end{array}$ \\
\hline Mandatory & $\begin{array}{l}\text { 402.4 Air leakage. } \\
\text { 402.4.1 Building } \\
\text { thermal envelope. (5) }\end{array}$ & $\begin{array}{l}\text { The following shall be caulked, gasketed, } \\
\text { weatherstripped or otherwise sealed with an air } \\
\text { barrier material, suitable film or solid material: }\end{array}$ & $\begin{array}{l}\text { 703.2 Insulation and air sealing (Optional, } \\
\text { Prescriptive path). } \\
\text { 703.2.1.4 Ceilings and attics. }\end{array}$ & $\begin{array}{l}\text { Optional - if the ICC } 700 \text { points are achieved } \\
\text { the } 2009 \text { IECC requirement will be met. }\end{array}$ \\
\hline
\end{tabular}




\begin{tabular}{|c|c|c|c|c|}
\hline $\begin{array}{l}\text { Requirement } \\
\text { Category }\end{array}$ & $\begin{array}{c}\text { IECC Requirement } \\
\text { Reference }\end{array}$ & IECC 2009 & ICC-700 & Comments \\
\hline & & $\begin{array}{l}\text { 5. Dropped ceilings or chases adjacent to the } \\
\text { thermal envelope. }\end{array}$ & $\begin{array}{l}\text { (1) At dropped ceilings and soffits, the air barrier } \\
\text { is substantially aligned with insulation and any } \\
\text { gaps are sealed with caulk, foam, or tape. }\end{array}$ & \\
\hline Mandatory & $\begin{array}{l}\text { 402.4 Air leakage. } \\
\text { 402.4.1 Building } \\
\text { thermal envelope. (6) }\end{array}$ & $\begin{array}{l}\text { The following shall be caulked, gasketed, } \\
\text { weatherstripped or otherwise sealed with an air } \\
\text { barrier material, suitable film or solid material: } \\
\text { 6. Knee walls. }\end{array}$ & $\begin{array}{l}\text { 703.2 Insulation and air sealing (Optional, } \\
\text { Prescriptive path). } \\
\text { 703.2.1.3 Walls } \\
\text { (4) Skylight shafts and knee walls are air sealed. } \\
\text { Insulation on attic knee walls and skylight shafts } \\
\text { are physically supported by stapling in place, } \\
\text { netting, or using other mechanical attachment. } \\
\text { 703.2.1.4 Ceilings and attics. } \\
\text { (2) Access to vented attics, including knee wall } \\
\text { doors and/or drop down stairs, is caulked, } \\
\text { gasketed, or otherwise sealed. }\end{array}$ & $\begin{array}{l}\text { Optional - if the ICC } 700 \text { points are achieved } \\
\text { the } 2009 \text { IECC requirement will be met. }\end{array}$ \\
\hline Mandatory & $\begin{array}{l}\text { 402.4 Air leakage. } \\
\text { 402.4.1 Building } \\
\text { thermal envelope. (7) }\end{array}$ & $\begin{array}{l}\text { The following shall be caulked, gasketed, } \\
\text { weatherstripped or otherwise sealed with an air } \\
\text { barrier material, suitable film or solid material: } \\
\text { 7. Walls and ceilings separating a garage from } \\
\text { conditioned spaces. }\end{array}$ & $\begin{array}{l}\text { 703.2 Insulation and air sealing (Optional, } \\
\text { Prescriptive path). } \\
\text { 703.2.1.2 Air barriers. } \\
\text { Air barrier is installed at any exterior edge of } \\
\text { insulation at floors, foundations, and crawlspaces } \\
\text { including insulated floors above garages and } \\
\text { cantilevered floors. }\end{array}$ & $\begin{array}{l}\text { Optional - if the ICC } 700 \text { points are achieved } \\
\text { the } 2009 \text { IECC requirement will be met. }\end{array}$ \\
\hline Mandatory & $\begin{array}{l}\text { 402.4 Air leakage. } \\
\text { 402.4.1 Building } \\
\text { thermal envelope. (8) }\end{array}$ & $\begin{array}{l}\text { The following shall be caulked, gasketed, } \\
\text { weatherstripped or otherwise sealed with an air } \\
\text { barrier material, suitable film or solid material: } \\
\text { 8. Behind tubs and showers on exterior walls. }\end{array}$ & $\begin{array}{l}\text { 703.2 Insulation and air sealing (Optional, } \\
\text { Prescriptive path). } \\
\text { 703.2.1.3 Walls } \\
\text { (1) Exterior wall(s) behind the tub/shower is } \\
\text { insulated and includes an interior and exterior air } \\
\text { barrier. }\end{array}$ & $\begin{array}{l}\text { Optional - if the ICC } 700 \text { points are achieved } \\
\text { the } 2009 \text { IECC requirement will be met. }\end{array}$ \\
\hline Mandatory & $\begin{array}{l}\text { 402.4 Air leakage. } \\
\text { 402.4.1 Building } \\
\text { thermal envelope. (9) }\end{array}$ & $\begin{array}{l}\text { The following shall be caulked, gasketed, } \\
\text { weatherstripped or otherwise sealed with an air } \\
\text { barrier material, suitable film or solid material: } \\
\text { 9. Common walls between dwelling units. }\end{array}$ & $\begin{array}{l}\text { 703.2 Insulation and air sealing (Optional, } \\
\text { Prescriptive path). } \\
\text { 703.2.1.3 Walls } \\
\text { (3) Duplex and townhouse construction: In the } \\
\text { common walls between dwelling units (e.g., } \\
\text { gypsum shaft wall), an air barrier is installed to } \\
\text { seal the gap between the common wall and the } \\
\text { structural framing. }\end{array}$ & $\begin{array}{l}\text { Optional - if the ICC } 700 \text { points are achieved } \\
\text { the } 2009 \text { IECC requirement will be met. }\end{array}$ \\
\hline Mandatory & $\begin{array}{l}\text { 402.4 Air leakage. } \\
\text { 402.4.1 Building } \\
\text { thermal envelope. (10) }\end{array}$ & $\begin{array}{l}\text { The following shall be caulked, gasketed, } \\
\text { weatherstripped or otherwise sealed with an air } \\
\text { barrier material, suitable film or solid material: } \\
\text { 10. Attic access openings. }\end{array}$ & $\begin{array}{l}\text { 703.2 Insulation and air sealing (Optional, } \\
\text { Prescriptive path). } \\
\text { 703.2.1.4 Ceilings and attics. } \\
\text { (2) Access to vented attics, including knee wall } \\
\text { doors and/or drop down stairs, is caulked, } \\
\text { gasketed, or otherwise sealed. }\end{array}$ & $\begin{array}{l}\text { Optional - if the ICC } 700 \text { points are achieved } \\
\text { the } 2009 \text { IECC requirement will be met. }\end{array}$ \\
\hline Mandatory & $\begin{array}{l}\text { 402.4 Air leakage. } \\
\text { 402.4.1 Building } \\
\text { thermal envelope. (11) }\end{array}$ & $\begin{array}{l}\text { The following shall be caulked, gasketed, } \\
\text { weatherstripped or otherwise sealed with an air } \\
\text { barrier material, suitable film or solid material: } \\
\text { 11. Rim joist junction. }\end{array}$ & $\begin{array}{l}\text { 701.4.3. Insulation and air sealing (Mandatory) } \\
\text { 701.4.3.3 Walls } \\
\text { (2) Band joist and rim joints. Band and rim joists } \\
\text { are insulated and air sealed. }\end{array}$ & $\begin{array}{l}\text { Mandatory - ICC } 700 \text { requirement meets the } \\
2009 \text { IECC requirement. }\end{array}$ \\
\hline Mandatory & $\begin{array}{l}\text { 402.4 Air leakage. } \\
\text { 402.4.1 Building }\end{array}$ & $\begin{array}{l}\text { The following shall be caulked, gasketed, } \\
\text { weatherstripped or otherwise sealed with an air }\end{array}$ & $\begin{array}{l}\text { 701.4.3.3 Walls (Mandatory) } \\
\text { (3) Between foundation and sill plate bottom } \\
\end{array}$ & $\begin{array}{l}\text { Although ICC } 700 \text { includes mandatory and } \\
\text { optional points for other sources of infiltration, }\end{array}$ \\
\hline
\end{tabular}




\begin{tabular}{|c|c|c|c|c|}
\hline $\begin{array}{c}\text { Requirement } \\
\text { Category }\end{array}$ & $\begin{array}{c}\text { IECC Requirement } \\
\text { Reference }\end{array}$ & IECC 2009 & ICC-700 & Comments \\
\hline & thermal envelope. (12) & $\begin{array}{l}\text { barrier material, suitable film or solid material: } \\
\text { 12. Other sources of infiltration. }\end{array}$ & $\begin{array}{l}\text { plate... } \\
\text { (5) Exterior architectural features. Code required } \\
\text { building envelope insulation and air sealing are } \\
\text { not disrupted at exterior architectural features } \\
\text { such as stairs and decks. } \\
\text { 703.2.1.1.4 HVAC register boots (Optional). } \\
\text { HVAC register boots that penetrate the building } \\
\text { envelope are caulked or sealed to the subfloor or } \\
\text { drywall. } \\
\text { 703.2.1.4 Ceilings and attics (Optional). } \\
\text { (3) An insulated cover is gasketed or sealed to the } \\
\text { attic opening where a whole building or whole } \\
\text { dwelling unit fan penetrates into the attic. }\end{array}$ & $\begin{array}{l}\text { ICC } 700 \text { does not include a general } \\
\text { overarching requirement like the } 2009 \text { IECC, } \\
\text { thus the requirement is only partially met. }\end{array}$ \\
\hline Mandatory & $\begin{array}{l}\text { 402.4 Air leakage. } \\
\text { 402.4.2 Air sealing } \\
\text { and insulation. } \\
\text { 402.4.2.1 Testing } \\
\text { option. }\end{array}$ & $\begin{array}{l}\text { Building envelope air tightness and insulation } \\
\text { installation shall be demonstrated to comply with } \\
\text { one of the following options given by Section } \\
402.4 .2 .1 \text { or } 402.4 .2 .2 \text { : } \\
\text { 402.4.2.1 Testing option. Building envelope } \\
\text { tightness and insulation installation shall be } \\
\text { considered acceptable when tested air leakage is } \\
\text { less than seven air changes per hour (ACH) } \\
\text { when tested with a blower door at a pressure of } \\
50 \text { pascals (1 psf). Testing shall occur after rough } \\
\text { in and after installation of penetrations of the } \\
\text { building envelope, including penetrations for } \\
\text { utilities, plumbing, electrical, ventilation and } \\
\text { combustion appliances. } \\
\text { During testing: } \\
\text { 1. Exterior windows and doors, fireplace and } \\
\text { stove doors shall be closed, but not sealed; } \\
\text { 2. Dampers shall be closed, but not sealed, } \\
\text { including exhaust, intake, makeup air, backdraft } \\
\text { and flue dampers; } \\
\text { 3. Interior doors shall be open; } \\
\text { 4. Exterior openings for continuous ventilation } \\
\text { systems and heat recovery ventilators shall be } \\
\text { closed and sealed; } \\
\text { 5. Heating and cooling system(s) shall be turned } \\
\text { off; } \\
\text { 6. HVAC ducts shall not be sealed; and } \\
\text { 7. Supply and return registers shall not be sealed. }\end{array}$ & $\begin{array}{l}\text { 704.6 Installation and performance verification } \\
\text { (Optional). } \\
704.6 .1 \text { Third-party on-site inspection is } \\
\text { conducted to verify compliance with all of the } \\
\text { following, as applicable. Minimum of two } \\
\text { inspections are performed. One inspection after } \\
\text { insulation is installed and prior to being covered, } \\
\text { and another inspection upon completion of the } \\
\text { project... } \\
704.6 .2 \text { Third party testing is conducted to verify } \\
\text { performance. } \\
704.6 .2 .1 \text { Building envelope leakage rate is } \\
\text { demonstrated by blower door test. In addition to } \\
\text { the test, the following practices are required... } \\
\text { (4) The maximum leakage rate is in accordance } \\
\text { with: } \\
\text { (a) } 5 \text { ACH50 (3 points) } \\
\text { (b) } 4 \text { ACH50 (6 points) } \\
\text { (c) } 3 \text { ACH50 (9 points) } \\
\text { (d) } 2 \text { ACH50 (12 points) } \\
\text { (e) } 1 \text { ACH50 (15 points) }\end{array}$ & $\begin{array}{l}\text { Optional - If the minimum ICC } 700 \text { points (3) } \\
\text { are achieved, a maximum allowable leakage } \\
\text { rate of } 3 \text { air changes per hour (ACH) at a } \\
\text { pressure of } 50 \mathrm{~Pa} \text { is required, which is less } \\
\text { than the } 2009 \text { IECC maximum rate of } 7 \text { ACH50 } \\
\text { and the } 2009 \text { IECC requirement will be met. }\end{array}$ \\
\hline Mandatory & $\begin{array}{l}\text { 402.4 Air leakage. } \\
\text { 402.4.2 Air sealing } \\
\text { and insulation. } \\
\text { 402.4.2.2 Visual } \\
\text { inspection option. }\end{array}$ & $\begin{array}{l}\text { Building envelope air tightness and insulation } \\
\text { installation shall be demonstrated to comply with } \\
\text { one of the following options given by Section } \\
\text { 402.4.2.1 or 402.4.2.2: } \\
\text { 402.4.2.2 Visual inspection option. Building } \\
\text { envelope tightness and insulation installation }\end{array}$ & $\begin{array}{l}\text { 703.2 Insulation and air sealing (Optional, } \\
\text { Prescriptive path). } \\
\text { 703.2.1 Insulation and air sealing is installed in } \\
\text { accordance with all of the following [Sections } \\
\text { 703.2.1.1-703.2.1.4], as applicable: } \\
\text { (1) third-party verification performed }\end{array}$ & $\begin{array}{l}\text { Optional - If the ICC } 700 \text { points under Section } \\
703.2 \text { and } 704.6 \text { are achieved ,in either section, } \\
\text { the } 2009 \text { IECC requirement will be met. }\end{array}$ \\
\hline
\end{tabular}




\begin{tabular}{|c|c|c|c|c|}
\hline $\begin{array}{l}\text { Requirement } \\
\text { Category }\end{array}$ & $\begin{array}{c}\text { IECC Requirement } \\
\text { Reference }\end{array}$ & IECC 2009 & ICC-700 & Comments \\
\hline & & $\begin{array}{l}\text { shall be considered acceptable when the items } \\
\text { listed in Table } 402.4 .2 \text {, applicable to the method } \\
\text { of construction, are field verified. Where } \\
\text { required by the code official, an approved party } \\
\text { independent from the installer of the insulation } \\
\text { shall inspect the air barrier and insulation. }\end{array}$ & $\begin{array}{l}\text { 704.6 Installation and performance verification } \\
\text { (Optional). } \\
\text { 704.6.1 Third-party on-site inspection is } \\
\text { conducted to verify compliance with all of the } \\
\text { following, as applicable. Minimum of two } \\
\text { inspections are performed. One inspection after } \\
\text { insulation is installed and prior to being covered, } \\
\text { and another inspection upon completion of the } \\
\text { project... }\end{array}$ & \\
\hline Mandatory & $\begin{array}{l}\text { 402.4 Air leakage. } \\
\text { 402.4.3 Fireplaces. }\end{array}$ & $\begin{array}{l}\text { New wood-burning fireplaces shall have } \\
\text { gasketed doors and outdoor combustion air. }\end{array}$ & $\begin{array}{l}\text { 703.2.1.1.5 Masonry Fireplaces (Optional, } \\
\text { Prescriptive path). Masonry fireplaces are } \\
\text { equipped with gasketed doors, outside combustion } \\
\text { air, and a chimney top damper. }\end{array}$ & $\begin{array}{l}\text { Optional - If points are achieved the ICC } 700 \\
\text { requirement meets the } 2009 \text { IECC requirement. }\end{array}$ \\
\hline Mandatory & $\begin{array}{l}\text { 402.4 Air leakage. } \\
\text { 402.4.4 Fenestration } \\
\text { air leakage. }\end{array}$ & $\begin{array}{l}\text { Windows, skylights and sliding glass doors shall } \\
\text { have an air infiltration rate of no more than } 0.3 \\
\text { cfm per square foot }(1.5 \mathrm{~L} / \mathrm{s} / \mathrm{m} 2) \text {, and swinging } \\
\text { doors no more than } 0.5 \mathrm{cfm} \text { per square foot ( } 2.6 \\
\mathrm{~L} / \mathrm{s} / \mathrm{m} 2) \text {, when tested according to NFRC } 400 \text { or } \\
\text { AAMA/WDMA/CSA } 101 / \mathrm{I} . \mathrm{S} .2 / \mathrm{A} 440 \text { by an } \\
\text { accredited, independent laboratory and listed and } \\
\text { labeled by the manufacturer. } \\
\text { Exceptions: Site-built windows, skylights and } \\
\text { doors. }\end{array}$ & (2) & Not explicitly mentioned in ICC 700. \\
\hline Mandatory & $\begin{array}{l}\text { 402.4 Air leakage. } \\
\text { 402.4.5 Recessed } \\
\text { lighting. }\end{array}$ & $\begin{array}{l}\text { Recessed luminaires installed in the building } \\
\text { thermal envelope shall be sealed to limit air } \\
\text { leakage between conditioned and unconditioned } \\
\text { spaces. All recessed luminaires shall be IC-rated } \\
\text { and labeled as meeting ASTM E } 283 \text { when tested } \\
\text { at } 1.57 \mathrm{psf}(75 \mathrm{~Pa}) \text { pressure differential with no } \\
\text { more than } 2.0 \mathrm{cfm}(0.944 \mathrm{~L} / \mathrm{s}) \text { of air movement } \\
\text { from the conditioned space to the ceiling cavity. } \\
\text { All recessed luminaires shall be sealed with a } \\
\text { gasket or caulk between the housing and the } \\
\text { interior wall or ceiling covering. }\end{array}$ & $\begin{array}{l}\text { 701.4.3.4 Ceilings and attics (Mandatory) } \\
\text { (2) Recessed lighting. Recessed light fixtures that } \\
\text { penetrate the thermal envelope are airtight, IC- } \\
\text { rated, and sealed with gasket, caulk, or foam. }\end{array}$ & $\begin{array}{l}\text { Mandatory - The ICC } 700 \text { requirement meets } \\
\text { the } 2009 \text { IECC requirement. }\end{array}$ \\
\hline Mandatory & $\begin{array}{l}\text { 402.5 Maximum } \\
\text { fenestration U-factor } \\
\text { and SHGC. }\end{array}$ & $\begin{array}{l}\text { The area-weighted average maximum } \\
\text { fenestration U-factor permitted using trade-offs } \\
\text { from Section } 402.1 .4 \text { or } 404 \text { shall be } 0.48 \text { in } \\
\text { Zones } 4 \text { and } 5 \text { and } 0.40 \text { in Zones } 6 \text { through } 8 \text { for } \\
\text { vertical fenestration, and } 0.75 \text { in Zones } 4 \text { through } \\
8 \text { for skylights. The area-weighted average } \\
\text { maximum fenestration SHGC permitted using } \\
\text { trade-offs from Section } 404 \text { in Zones } 1 \text { through } 3 \\
\text { shall be } 0.50 \text {. }\end{array}$ & - & $\begin{array}{l}\text { ICC } 700 \text { requires compliance with the } 2006 \\
\text { IECC. The } 2006 \text { IECC SHGC values are } \\
\text { slightly higher than the } 2009 \text { IECC, therefore, } \\
\text { the ICC } 700 \text { does not fully meet the } 2009 \text { IECC } \\
\text { requirement. }\end{array}$ \\
\hline Mandatory & $\begin{array}{l}\text { 403.1 Controls. } \\
\text { 403.1.1 Programmable } \\
\text { thermostat. }\end{array}$ & $\begin{array}{l}\text { At least one thermostat shall be provided for } \\
\text { each separate heating and cooling system. } \\
\text { 403.1.1 Programmable thermostat. Where the } \\
\text { primary heating system is a forced-air furnace, at }\end{array}$ & $\begin{array}{l}\text { 703.4 HVAC equipment efficiency (Optional, } \\
\text { Prescriptive path) } \\
\text { 703.4.10 An ENERGY STAR, or equivalent, } \\
\text { programmable thermostat is installed to control }\end{array}$ & $\begin{array}{l}\text { Optional - If the ICC } 700 \text { points are achieved, } \\
2009 \text { IECC requirement is not necessarily met } \\
\text { since the } 2009 \text { IECC defines specific } \\
\text { parameters for the programmable thermostat }\end{array}$ \\
\hline
\end{tabular}




\begin{tabular}{|c|c|c|c|c|}
\hline $\begin{array}{l}\text { Requirement } \\
\text { Category }\end{array}$ & $\begin{array}{l}\text { IECC Requirement } \\
\text { Reference }\end{array}$ & IECC 2009 & ICC-700 & Comments \\
\hline & & $\begin{array}{l}\text { least one thermostat per dwelling unit shall be } \\
\text { capable of controlling the heating and cooling } \\
\text { system on a daily schedule to maintain different } \\
\text { temperature set points at different times of the } \\
\text { day. This thermostat shall include the capability } \\
\text { to set back or temporarily operate the system to } \\
\text { maintain zone temperatures down to } 55^{\circ} \mathrm{F}\left(13^{\circ} \mathrm{C}\right) \\
\text { or up to } 85^{\circ} \mathrm{F}\left(29^{\circ} \mathrm{C}\right) \text {. The thermostat shall } \\
\text { initially be programmed with a heating } \\
\text { temperature set point no higher than } 70^{\circ} \mathrm{F}\left(21^{\circ} \mathrm{C}\right) \\
\text { and a cooling temperature set point no lower } \\
\text { than } 78^{\circ} \mathrm{F}\left(26^{\circ} \mathrm{C}\right) \text {. }\end{array}$ & $\begin{array}{l}\text { each heating and cooling zone. } \\
\text { 705.1 Energy consumption control. (Optional) } \\
\text { A whole building or whole dwelling unit device is } \\
\text { installed that controls or monitors energy } \\
\text { consumption. } \\
\text { (1) programmable communicating thermostat } \\
\text { (2) Energy-monitoring device } \\
\text { (3) energy management control system }\end{array}$ & and ICC 700 does not. \\
\hline Mandatory & $\begin{array}{l}\text { 403.1 Controls. } \\
\text { 403.1.2 Heat pump } \\
\text { supplementary heat. }\end{array}$ & $\begin{array}{l}\text { Heat pumps having supplementary electric- } \\
\text { resistance heat shall have controls that, except } \\
\text { during defrost, prevent supplemental heat } \\
\text { operation when the heat pump compressor can } \\
\text { meet the heating load. }\end{array}$ & $\begin{array}{l}\text { 703.4 HVAC equipment efficiency (Optional, } \\
\text { Prescriptive path) } \\
\text { 703.4.4 Heat pump heating efficiency is in } \\
\text { accordance with Table } 703.4 .4 \text {. Refrigerant } \\
\text { charge is verified for compliance with } \\
\text { manufacturer's instructions. } \\
\text { Zones 5-9 require consideration for use of } \\
\text { resistance heat in cold climates when installing a } \\
\text { heat pump. }\end{array}$ & $\begin{array}{l}\text { Optional - If the ICC } 700 \text { points are achieved, } \\
\text { the } 2009 \text { IECC requirements may or may not } \\
\text { be met because supplementary resistance } \\
\text { heating controls are not mentioned in ICC } 700 .\end{array}$ \\
\hline Prescriptive & $\begin{array}{l}\text { 403.2 Ducts. } 403.2 .1 \\
\text { Insulation. }\end{array}$ & $\begin{array}{l}\text { Supply ducts in attics shall be insulated to a } \\
\text { minimum of R-8. All other ducts shall be } \\
\text { insulated to a minimum of R-6. } \\
\text { Exception: Ducts or portions thereof located } \\
\text { completely inside the building thermal envelope. }\end{array}$ & $\begin{array}{l}\text { 704.4 Ducts (Optional). } \\
\text { 704.4.2 Space heating is provided by a system that } \\
\text { does not include air ducts. } \\
\text { 704.4.3 Space cooling is provided by a system } \\
\text { that does not include air ducts. }\end{array}$ & $\begin{array}{l}\text { Optional - If the ECC } 700 \text { points for ductless } \\
\text { systems are achieved, the } 2009 \text { IECC } \\
\text { requirement will be met. }\end{array}$ \\
\hline Mandatory & $\begin{array}{l}\text { 403.2 Ducts. } 403.2 .2 \\
\text { Sealing. }\end{array}$ & $\begin{array}{l}\text { All ducts, air handlers, filter boxes and building } \\
\text { cavities used as ducts shall be sealed. Joints and } \\
\text { seams shall comply with Section M1601.4.1 of } \\
\text { the International Residential Code. }\end{array}$ & $\begin{array}{l}\text { 701.4.2 Duct systems (Mandatory). } \\
\text { 701.4.2.1 Ducts are sealed with tape complying } \\
\text { with UL 181, mastic, gaskets, or an approved } \\
\text { system as required by the IRC, Section } \\
\text { M1601.3.1, or IMC, Section 603.9, to reduce } \\
\text { leakage. }\end{array}$ & $\begin{array}{l}\text { Mandatory - ICC } 700 \text { requirement meets the } \\
2009 \text { IECC requirement. }\end{array}$ \\
\hline Mandatory & $\begin{array}{l}403.2 \text { Ducts. } 403.2 .2 \\
\text { Sealing. (1-2) }\end{array}$ & $\begin{array}{l}\text { Duct tightness shall be verified by either of the } \\
\text { following: } \\
\text { 1. Post-construction test: Leakage to outdoors } \\
\text { shall be less than or equal to } 8 \mathrm{cfm}(226.5 \mathrm{~L} / \mathrm{min}) \\
\text { per } 100 \mathrm{ft} 2(9.29 \mathrm{~m} 2) \text { of conditioned floor area } \\
\text { or a total leakage less than or equal to } 12 \mathrm{cfm}(12 \\
\mathrm{L} / \mathrm{min}) \text { per } 100 \mathrm{ft} 2(9.29 \mathrm{~m} 2) \text { of conditioned } \\
\text { floor area when tested at a pressure differential } \\
\text { of } 0.1 \text { inches w.g. ( } 25 \mathrm{~Pa}) \text { across the entire } \\
\text { system, including the manufacturer's air handler } \\
\text { enclosure. All register boots shall be taped or } \\
\text { otherwise sealed during the test. } \\
\text { 2. Rough-in test: Total leakage shall be less than } \\
\text { or equal to } 6 \mathrm{cfm}(169.9 \mathrm{~L} / \mathrm{min}) \text { per } 100 \mathrm{ft} 2(9.29\end{array}$ & $\begin{array}{l}\text { 704.6 Installation and performance } \\
\text { verification. (Optional) } \\
704.6 .2 .2 \text { The entire central HVAC duct system, } \\
\text { including air handlers and register boots, is tested } \\
\text { for leakage at a pressure differential of } 0.1 \text { inches } \\
\text { w.g. ( } 25 \mathrm{~Pa} \text { ). The maximum leakage as a percent } \\
\text { of the system design flow rate is in accordance } \\
\text { with the following: } \\
\text { (1) } 6 \text { percent for ductwork entirely outside the } \\
\text { building's thermal envelope } \\
\text { (2) } 6 \text { percent for ductwork entirely inside the } \\
\text { building's thermal envelope } \\
\text { (3) } 6 \text { percent for ductwork both inside and outside } \\
\text { the building's thermal envelope }\end{array}$ & $\begin{array}{l}\text { Optional - If the ICC } 700 \text { points are achieved, } \\
\text { the } 2009 \text { IECC requirement will be met. }\end{array}$ \\
\hline
\end{tabular}




\begin{tabular}{|c|c|c|c|c|}
\hline $\begin{array}{c}\text { Requirement } \\
\text { Category }\end{array}$ & $\begin{array}{l}\text { IECC Requirement } \\
\text { Reference }\end{array}$ & IECC 2009 & ICC-700 & Comments \\
\hline & & $\begin{array}{l}\text { m2) of conditioned floor area when tested at a } \\
\text { pressure differential of } 0.1 \text { inches w.g. ( } 25 \mathrm{~Pa} \text { ) } \\
\text { across the roughed in system, including the } \\
\text { manufacturer's air handler enclosure. All register } \\
\text { boots shall be taped or otherwise sealed during } \\
\text { the test. If the air handler is not installed at the } \\
\text { time of the test, total leakage shall be less than or } \\
\text { equal to } 4 \mathrm{cfm}(113.3 \mathrm{~L} / \mathrm{min}) \text { per } 100 \mathrm{ft} 2 \text { ( } 9.29 \\
\mathrm{~m} 2) \text { of conditioned floor area. } \\
\text { Exceptions: Duct tightness test is not required if } \\
\text { the air handler and all ducts are located within } \\
\text { conditioned space. }\end{array}$ & & \\
\hline Mandatory & $\begin{array}{l}403.2 \text { Ducts. } 403.2 .3 \\
\text { Building cavities. }\end{array}$ & $\begin{array}{l}\text { Building framing cavities shall not be used as } \\
\text { supply ducts. }\end{array}$ & $\begin{array}{l}\text { 701.4.2 Duct Systems (Mandatory). } \\
\text { 701.4.2.2 Building cavities are not used as supply } \\
\text { ducts. }\end{array}$ & $\begin{array}{l}\text { Mandatory - ICC } 700 \text { requirement meets the } \\
2009 \text { IECC requirement. }\end{array}$ \\
\hline Mandatory & $\begin{array}{l}\text { 403.3 Mechanical } \\
\text { system piping } \\
\text { insulation. }\end{array}$ & $\begin{array}{l}\text { Mechanical system piping capable of carrying } \\
\text { fluids above } 105^{\circ} \mathrm{F}\left(41^{\circ} \mathrm{C}\right) \text { or below } 55^{\circ} \mathrm{F}\left(13^{\circ} \mathrm{C}\right) \\
\text { shall be insulated to a minimum of R-3. }\end{array}$ & - & Not explicitly mentioned in ICC 700. \\
\hline Mandatory & $\begin{array}{l}403.5 \text { Mechanical } \\
\text { ventilation. }\end{array}$ & $\begin{array}{l}\text { Outdoor air intakes and exhausts shall have } \\
\text { automatic or gravity dampers that close when the } \\
\text { ventilation system is not operating. }\end{array}$ & 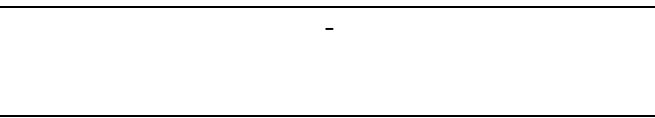 & Not explicitly mentioned in ICC 700. \\
\hline Mandatory & $\begin{array}{l}403.6 \text { Equipment } \\
\text { sizing. }\end{array}$ & $\begin{array}{l}\text { Heating and cooling equipment shall be sized in } \\
\text { accordance with Section M1401.3 of the } \\
\text { International Residential Code. }\end{array}$ & $\begin{array}{l}\text { 701.4.1 HVAC systems (Mandatory). } \\
\text { 701.4.1.1 Space heating and cooling } \\
\text { systems/equipment is sized according to heating } \\
\text { and cooling loads calculated using ACCA Manual } \\
\text { J, or equivalent. } \\
\text { 701.4.1.2 Where installed as a primary heat source } \\
\text { in the building, radiant or hydronic space heating } \\
\text { system is designed using industry-approved } \\
\text { guidelines (e.g., ACCA Manual J, GAMA H-22, } \\
\text { or an accredited design professional's and } \\
\text { manufacturer's recommendations). }\end{array}$ & $\begin{array}{l}\text { Mandatory - ICC } 700 \text { requirement meets the } \\
2009 \text { IECC requirement. }\end{array}$ \\
\hline Mandatory & $\begin{array}{l}\text { 403.8 Snow melt } \\
\text { system controls. }\end{array}$ & $\begin{array}{l}\text { Snow- and ice-melting systems, supplied through } \\
\text { energy service to the building, shall include } \\
\text { automatic controls capable of shutting off the } \\
\text { system when the pavement temperature is above } \\
50^{\circ} \mathrm{F} \text {, and no precipitation is falling and an } \\
\text { automatic or manual control that will allow }\end{array}$ & - & Not explicitly mentioned in ICC 700. \\
\hline
\end{tabular}




\begin{tabular}{|c|c|c|c|c|}
\hline $\begin{array}{l}\text { Requirement } \\
\text { Category }\end{array}$ & $\begin{array}{l}\text { IECC Requirement } \\
\text { Reference }\end{array}$ & IECC 2009 & ICC-700 & Comments \\
\hline & & $\begin{array}{l}\text { shutoff when the outdoor temperature is above } \\
40^{\circ} \mathrm{F} \text {. }\end{array}$ & & \\
\hline Mandatory & $\begin{array}{l}\text { 403.9 Pools. } 403.9 .1 \\
\text { Pool heaters. }\end{array}$ & $\begin{array}{l}\text { Pools shall be provided with energy-conserving } \\
\text { measures in accordance with Sections } 403.9 .1 \\
\text { through } 403.9 .3 \text {. } \\
403.9 .1 \text { Pool heaters. All pool heaters shall be } \\
\text { equipped with a readily accessible on-off switch } \\
\text { to allow shutting off the heater without adjusting } \\
\text { the thermostat setting. Pool heaters fired by } \\
\text { natural gas or LPG shall not have continuously } \\
\text { burning pilot lights. }\end{array}$ & - & Not explicitly mentioned in ICC 700. \\
\hline Mandatory & $\begin{array}{l}403.9 \text { Pools. } 403.9 .2 \\
\text { Time switches. }\end{array}$ & $\begin{array}{l}\text { Time switches that can automatically turn off } \\
\text { and on heaters and pumps according to a preset } \\
\text { schedule shall be installed on swimming pool } \\
\text { heaters and pumps. } \\
\text { Exceptions: } \\
\text { 1. Where public health standards require 24-hour } \\
\text { pump operation. } \\
\text { 2. Where pumps are required to operate solar- } \\
\text { and waste-heat-recovery pool heating systems. }\end{array}$ & - & Not explicitly mentioned in ICC 700. \\
\hline Mandatory & $\begin{array}{l}403.9 \text { Pools. } 403.9 .3 \\
\text { Pool covers. }\end{array}$ & $\begin{array}{l}\text { Heated pools shall be equipped with a vapor- } \\
\text { retardant pool cover on or at the water surface. } \\
\text { Pools heated to more than } 90^{\circ} \mathrm{F}\left(32^{\circ} \mathrm{C}\right) \text { shall } \\
\text { have a pool cover with a minimum insulation } \\
\text { value of R-12. } \\
\text { Exception: Pools deriving over } 60 \text { percent of the } \\
\text { energy for heating from site-recovered energy or } \\
\text { solar energy source. }\end{array}$ & - & Not explicitly mentioned in ICC 700. \\
\hline Prescriptive & $\begin{array}{l}\text { 404.1 Lighting } \\
\text { equipment. }\end{array}$ & $\begin{array}{l}\text { A minimum of } 50 \text { percent of the lamps in } \\
\text { permanently installed lighting fixtures shall be } \\
\text { high-efficacy lamps. }\end{array}$ & $\begin{array}{l}\text { 704.2 Lighting and appliances } \\
704.2 .1 \text { Hard-wired lighting is in accordance with } \\
\text { one of the following: } \\
\text { (1) A minimum of } 50 \text { percent of the total hard- } \\
\text { wired lighting fixtures, or the bulbs in those } \\
\text { fixtures, qualify as ENERGY STAR or } \\
\text { equivalent. } \\
\text { (2) A minimum of } 50 \text { percent of the total hard- } \\
\text { wired lighting fixtures qualify as ENERGY STAR } \\
\text { or equivalent. } \\
\text { (3) A minimum of } 80 \text { percent of the exterior } \\
\text { lighting wattage has an efficiency of } 40 \text { lumens } \\
\text { per watt minimum or be a solar-powered light } \\
\text { fixture. }\end{array}$ & $\begin{array}{l}\text { Optional - If the ICC } 700 \text { points for option } 1 \\
\text { or } 2 \text { are achieved, the } 2009 \text { IECC requirement } \\
\text { will be met. }\end{array}$ \\
\hline Performance & $\begin{array}{l}405.2 \text { Mandatory } \\
\text { requirements. }\end{array}$ & $\begin{array}{l}\text { Compliance with this section requires that the } \\
\text { mandatory provisions identified in Section } 401.2 \\
\text { be met. All supply and return ducts not } \\
\text { completely inside the building thermal envelope } \\
\text { shall be insulated to a minimum of R- } 6 \text {. }\end{array}$ & $\begin{array}{l}\text { 704.4 Ducts. } \\
\text { 704.4.2 Space heating is provided by a system that } \\
\text { does not include air ducts. ( } 15 \text { points) } \\
704.4 .3 \text { Space cooling is provided by a system } \\
\text { that does not include air ducts. ( } 15 \text { points) }\end{array}$ & $\begin{array}{l}\text { Optional - If the ICC } 700 \text { points are achieved } \\
\text { for section } 704.4 .2 \text { OR } 704.4 .4 \text {, the } 2009 \text { IECC } \\
\text { requirement will be met indirectly because } \\
\text { there will be no supply or return ducts outside } \\
\text { of the building thermal envelope. }\end{array}$ \\
\hline
\end{tabular}




\begin{tabular}{|c|c|c|c|c|}
\hline $\begin{array}{c}\text { Requirement } \\
\text { Category }\end{array}$ & $\begin{array}{c}\text { IECC Requirement } \\
\text { Reference }\end{array}$ & IECC 2009 & ICC-700 & Comments \\
\hline & & & $\begin{array}{l}\text { 704.4.4 Ductwork is in accordance with all of the } \\
\text { following: ( } 12 \text { points) } \\
\text { (1) Building cavities are not used as return } \\
\text { ductwork. } \\
\text { (2) Heating and cooling ducts and mechanical } \\
\text { equipment are installed within the conditioned } \\
\text { building space. } \\
\text { (3) Ductwork is not installed in exterior walls. }\end{array}$ & \\
\hline Performance & $\begin{array}{l}405.3 \text { Performance- } \\
\text { based compliance. }\end{array}$ & $\begin{array}{l}\text { Compliance based on simulated energy } \\
\text { performance requires that a proposed residence } \\
\text { (proposed design) be shown to have an annual } \\
\text { energy cost that is less than or equal to the } \\
\text { annual energy cost of the standard reference } \\
\text { design. Energy prices shall be taken from a } \\
\text { source approved by the code official, such as the } \\
\text { Department of Energy, Energy Information } \\
\text { Administration's State Energy Price and } \\
\text { Expenditure Report. Code officials shall be } \\
\text { permitted to require time-of-use pricing in } \\
\text { energy cost calculations. } \\
\text { Exception: The energy use based on source } \\
\text { energy expressed in Btu or Btu per square foot of } \\
\text { conditioned floor area shall be permitted to be } \\
\text { substituted for the energy cost. The source } \\
\text { energy multiplier for electricity shall be } 3.16 \text {. } \\
\text { The source energy multiplier for fuels other than } \\
\text { electricity shall be } 1.1 \text {. }\end{array}$ & $\begin{array}{l}\text { 702.2 Energy cost performance levels } \\
\text { (Performance Path). Energy efficiency features } \\
\text { are implemented to achieve energy cost } \\
\text { performance that exceeds the } 2006 \text { IECC by the } \\
\text { following. A documented analysis using software } \\
\text { in accordance with IECC, Section 404, or } 2006 \\
\text { IECC Section } 506.2 \text { through } 506.5 \text {, applied as } \\
\text { defined in the } 2006 \text { IECC, is required. } \\
\text { (1) } 15 \text { percent (Mandatory - minimum } \\
\text { requirement) } \\
\text { (2) } 30 \text { percent } \\
\text { (3) } 50 \text { percent } \\
\text { (4) } 60 \text { percent }\end{array}$ & $\begin{array}{l}\text { ICC } 700 \text { requires a minimum of } 15 \% \\
\text { improvement in energy cost performance. If a } \\
\text { project follows the performance path, the } 2009 \\
\text { IECC requirement will be met. }\end{array}$ \\
\hline Performance & $\begin{array}{l}\text { 405.4 Documentation. } \\
\text { 405.4.1 Compliance } \\
\text { software tools. }\end{array}$ & $\begin{array}{l}\text { Documentation verifying that the methods and } \\
\text { accuracy of the compliance software tools } \\
\text { conform to the provisions of this section shall be } \\
\text { provided to the code official. }\end{array}$ & $\begin{array}{l}\text { 702.2 Energy cost performance levels } \\
\text { (Performance Path). Energy efficiency features } \\
\text { are implemented to achieve energy cost } \\
\text { performance that exceeds the } 2006 \text { IECC by the } \\
\text { following. A documented analysis using software } \\
\text { in accordance with IECC, Section 404, or } 2006 \\
\text { IECC Section 506.2 through 506.5, applied as } \\
\text { defined in the IECC, is required. }\end{array}$ & $\begin{array}{l}\text { ICC } 700 \text { requires documentation in accordance } \\
\text { with } 2006 \text { IECC if a project follows the } \\
\text { performance path. The requirement in the } \\
2006 \text { IECC meets the requirement of the } 2009 \\
\text { IECC. }\end{array}$ \\
\hline Performance & $\begin{array}{l}\text { 405.4 Documentation. } \\
\text { 405.4.2 Compliance } \\
\text { report. }\end{array}$ & $\begin{array}{l}\text { Compliance software tools shall generate a } \\
\text { report that documents that the proposed design } \\
\text { complies with Section } 405.3 \text {. }\end{array}$ & $\begin{array}{l}\text { 702.2 Energy cost performance levels } \\
\text { (Performance Path). Energy efficiency features } \\
\text { are implemented to achieve energy cost } \\
\text { performance that exceeds the } 2006 \text { IECC by the } \\
\text { following. A documented analysis using software } \\
\text { in accordance with } 2006 \text { IECC, Section 404, or } \\
2006 \text { IECC Section } 506.2 \text { through 506.5, applied } \\
\text { as defined in the } 2006 \text { IECC, is required. }\end{array}$ & $\begin{array}{l}\text { ICC } 700 \text { requires documentation in accordance } \\
\text { with } 2006 \text { IECC if a project follows the } \\
\text { performance path. The requirement in the } \\
2006 \text { IECC meets the requirement of the } 2009 \\
\text { IECC. }\end{array}$ \\
\hline Performance & $\begin{array}{l}\text { 405.4 Documentation. } \\
\text { 405.4.2 Compliance } \\
\text { report.(1) }\end{array}$ & $\begin{array}{l}\text { The compliance documentation shall include the } \\
\text { following information: } \\
\text { 1. Address or other identification of the } \\
\text { residence; }\end{array}$ & $\begin{array}{l}\text { 702.2 Energy cost performance levels } \\
\text { (Performance Path). Energy efficiency features } \\
\text { are implemented to achieve energy cost } \\
\text { performance that exceeds the } 2006 \text { IECC by the }\end{array}$ & $\begin{array}{l}\text { ICC } 700 \text { requires documentation in accordance } \\
\text { with } 2006 \text { IECC if a project follows the } \\
\text { performance path. The requirement in the } \\
2006 \text { IECC meets the requirement of the } 2009\end{array}$ \\
\hline
\end{tabular}




\begin{tabular}{|c|c|c|c|c|}
\hline $\begin{array}{l}\text { Requirement } \\
\text { Category }\end{array}$ & $\begin{array}{c}\text { IECC Requirement } \\
\text { Reference }\end{array}$ & IECC 2009 & ICC-700 & Comments \\
\hline & & & $\begin{array}{l}\text { following. A documented analysis using software } \\
\text { in accordance with } 2006 \text { IECC, Section 404, or } \\
2006 \text { IECC Section } 506.2 \text { through 506.5, applied } \\
\text { as defined in the } 2006 \text { IECC, is required. }\end{array}$ & IECC. \\
\hline Performance & $\begin{array}{l}\text { 405.4 Documentation. } \\
\text { 405.4.2 Compliance } \\
\text { report.(2) }\end{array}$ & $\begin{array}{l}\text { The compliance documentation shall include the } \\
\text { following information: } \\
\text { 2. An inspection checklist documenting the } \\
\text { building component characteristics of the } \\
\text { proposed design as listed in Table } 405.5 .2(1) \text {. } \\
\text { The inspection checklist shall show results for } \\
\text { both the standard reference design and the } \\
\text { proposed design, and shall document all inputs } \\
\text { entered by the user necessary to reproduce the } \\
\text { results; }\end{array}$ & $\begin{array}{l}\text { 702.2 Energy cost performance levels } \\
\text { (Performance Path). Energy efficiency features } \\
\text { are implemented to achieve energy cost } \\
\text { performance that exceeds the } 2006 \text { IECC by the } \\
\text { following. A documented analysis using software } \\
\text { in accordance with } 2006 \text { IECC, Section 404, or } \\
2006 \text { IECC Section } 506.2 \text { through 506.5, applied } \\
\text { as defined in the } 2006 \text { IECC, is required. }\end{array}$ & $\begin{array}{l}\text { ICC } 700 \text { requires documentation in accordance } \\
\text { with } 2006 \text { IECC if a project follows the } \\
\text { performance path. The requirement in the } \\
2006 \text { IECC meets the requirement of the } 2009 \\
\text { IECC. }\end{array}$ \\
\hline Performance & $\begin{array}{l}\text { 405.4 Documentation. } \\
\text { 405.4.2 Compliance } \\
\text { report.(3) }\end{array}$ & $\begin{array}{l}\text { The compliance documentation shall include the } \\
\text { following information: } \\
\text { 3. Name of individual completing the } \\
\text { compliance report; and }\end{array}$ & $\begin{array}{l}\text { 702.2 Energy cost performance levels } \\
\text { (Performance Path). Energy efficiency features } \\
\text { are implemented to achieve energy cost } \\
\text { performance that exceeds the } 2006 \text { IECC by the } \\
\text { following. A documented analysis using software } \\
\text { in accordance with } 2006 \text { IECC, Section 404, or } \\
\text { 2006 IECC Section } 506.2 \text { through 506.5, applied } \\
\text { as defined in the } 2006 \text { IECC, is required. }\end{array}$ & $\begin{array}{l}\text { ICC } 700 \text { requires documentation in accordance } \\
\text { with } 2006 \text { IECC if a project follows the } \\
\text { performance path. The requirement in the } \\
2006 \text { IECC meets the requirement of the } 2009 \\
\text { IECC. }\end{array}$ \\
\hline Performance & $\begin{array}{l}\text { 405.4 Documentation. } \\
\text { 405.4.2 Compliance } \\
\text { report.(4) }\end{array}$ & $\begin{array}{l}\text { The compliance documentation shall include the } \\
\text { following information: } \\
4 \text {. Name and version of the compliance software } \\
\text { tool. } \\
\text { Exception: Multiple orientations. When an } \\
\text { otherwise identical building model is offered in } \\
\text { multiple orientations, compliance for any } \\
\text { orientation shall be permitted by documenting } \\
\text { that the building meets the performance } \\
\text { requirements in each of the four cardinal (north, } \\
\text { east, south and west) orientations. }\end{array}$ & $\begin{array}{l}\text { 702.2 Energy cost performance levels } \\
\text { (Performance Path). Energy efficiency features } \\
\text { are implemented to achieve energy cost } \\
\text { performance that exceeds the } 2006 \text { IECC by the } \\
\text { following. A documented analysis using software } \\
\text { in accordance with IECC, Section 404, or } 2006 \\
\text { IECC Section 506.2 through 506.5, applied as } \\
\text { defined in the } 2006 \text { IECC, is required. }\end{array}$ & $\begin{array}{l}\text { ICC } 700 \text { requires documentation in accordance } \\
\text { with } 2006 \text { IECC if a project follows the } \\
\text { performance path. The requirement in the } \\
2006 \text { IECC meets the requirement of the } 2009 \\
\text { IECC. }\end{array}$ \\
\hline Performance & $\begin{array}{l}\text { 405.4 Documentation. } \\
\text { 405.4.3 Additional } \\
\text { documentation. }\end{array}$ & $\begin{array}{l}\text { The code official shall be permitted to require } \\
\text { the following documents: } \\
\text { 1. Documentation of the building component } \\
\text { characteristics of the standard reference design. } \\
\text { 2. A certification signed by the builder providing } \\
\text { the building component characteristics of the } \\
\text { proposed design as given in Table } 405.5 .2(1) \text {. } \\
\text { 3. Documentation of the actual values used in the } \\
\text { software calculations for the proposed design. }\end{array}$ & $\begin{array}{l}\text { 702.2 Energy cost performance levels } \\
\text { (Performance Path). Energy efficiency features } \\
\text { are implemented to achieve energy cost } \\
\text { performance that exceeds the } 2006 \text { IECC by the } \\
\text { following. A documented analysis using software } \\
\text { in accordance with } 2006 \text { IECC, Section 404, or } \\
2006 \text { IECC Section } 506.2 \text { through 506.5, applied } \\
\text { as defined in the } 2006 \text { IECC, is required. }\end{array}$ & $\begin{array}{l}\text { ICC } 700 \text { requires documentation in accordance } \\
\text { with } 2006 \text { IECC if a project follows the } \\
\text { performance path. The requirement in the } \\
2006 \text { IECC meets the requirement of the } 2009 \\
\text { IECC. }\end{array}$ \\
\hline Performance & $\begin{array}{l}405.5 \text { Calculation } \\
\text { procedure. }\end{array}$ & $\begin{array}{l}\text { 405.5.1 General. Except as specified by this } \\
\text { section, the standard reference design and } \\
\text { proposed design shall be configured and } \\
\text { analyzed using identical methods and techniques. } \\
\text { 405.5.2 Residence specifications. The standard }\end{array}$ & $\begin{array}{l}\text { 702.2 Energy cost performance levels } \\
\text { (Performance Path). Energy efficiency features } \\
\text { are implemented to achieve energy cost } \\
\text { performance that exceeds the } 2006 \text { IECC by the } \\
\text { following. A documented analysis using software }\end{array}$ & $\begin{array}{l}\text { ICC } 700 \text { requires documentation in accordance } \\
\text { with } 2006 \text { IECC if a project follows the } \\
\text { performance path. The requirement in the } \\
2006 \text { IECC meets the requirement of the } 2009 \\
\text { IECC. }\end{array}$ \\
\hline
\end{tabular}




\begin{tabular}{|c|c|c|c|c|}
\hline $\begin{array}{c}\text { Requirement } \\
\text { Category }\end{array}$ & $\begin{array}{c}\text { IECC Requirement } \\
\text { Reference }\end{array}$ & IECC 2009 & ICC-700 & Comments \\
\hline & & $\begin{array}{l}\text { reference design and proposed design shall be } \\
\text { configured and analyzed as specified by Table } \\
\text { 405.5.2(1). Table 405.5.2(1) shall include by } \\
\text { reference all notes contained in Table 402.1.1. }\end{array}$ & $\begin{array}{l}\text { in accordance with } 2006 \text { IECC, Section } 404 \text {, or } \\
2006 \text { IECC Section } 506.2 \text { through } 506.5 \text {, applied } \\
\text { as defined in the } 2006 \text { IECC, is required. }\end{array}$ & \\
\hline Performance & $\begin{array}{l}405.6 \text { Calculation } \\
\text { software tools. } 405.6 .1 \\
\text { Minimum capabilities. }\end{array}$ & $\begin{array}{l}\text { Calculation procedures used to comply with this } \\
\text { section shall be software tools capable of } \\
\text { calculating the annual energy consumption of all } \\
\text { building elements that differ between the } \\
\text { standard reference design and the proposed } \\
\text { design and shall include the following } \\
\text { capabilities: }\end{array}$ & $\begin{array}{l}\text { 702.2 Energy cost performance levels } \\
\text { (Performance Path). Energy efficiency features } \\
\text { are implemented to achieve energy cost } \\
\text { performance that exceeds the } 2006 \text { IECC by the } \\
\text { following. A documented analysis using software } \\
\text { in accordance with } 2006 \text { IECC, Section 404, or } \\
\text { 2006 IECC Section } 506.2 \text { through 506.5, applied } \\
\text { as defined in the } 2006 \text { IECC, is required. }\end{array}$ & $\begin{array}{l}\text { ICC } 700 \text { requires documentation in accordance } \\
\text { with } 2006 \text { IECC if a project follows the } \\
\text { performance path. The requirement in the } \\
2006 \text { IECC meets the requirement of the } 2009 \\
\text { IECC. }\end{array}$ \\
\hline Performance & $\begin{array}{l}\text { 405.6 Calculation } \\
\text { software tools. } 405.6 .1 \\
\text { Minimum } \\
\text { capabilities.(1) }\end{array}$ & $\begin{array}{l}\text { Calculation procedures ... and shall include the } \\
\text { following capabilities: } \\
\text { 1. Computer generation of the standard reference } \\
\text { design using only the input for the proposed } \\
\text { design. The calculation procedure shall not allow } \\
\text { the user to directly modify the building } \\
\text { component characteristics of the standard } \\
\text { reference design. }\end{array}$ & $\begin{array}{l}\text { 702.2 Energy cost performance levels } \\
\text { (Performance Path). Energy efficiency features } \\
\text { are implemented to achieve energy cost } \\
\text { performance that exceeds the } 2006 \text { IECC by the } \\
\text { following. A documented analysis using software } \\
\text { in accordance with } 2006 \text { IECC, Section } 404 \text {, or } \\
2006 \text { IECC Section } 506.2 \text { through 506.5, applied } \\
\text { as defined in the } 2006 \text { IECC, is required. }\end{array}$ & $\begin{array}{l}\text { ICC } 700 \text { requires documentation in accordance } \\
\text { with } 2006 \text { IECC if a project follows the } \\
\text { performance path. The requirement in the } \\
2006 \text { IECC meets the requirement of the } 2009 \\
\text { IECC. }\end{array}$ \\
\hline Performance & $\begin{array}{l}\text { 405.6 Calculation } \\
\text { software tools. } 405.6 .1 \\
\text { Minimum } \\
\text { capabilities.(2) }\end{array}$ & $\begin{array}{l}\text { Calculation procedures ... and shall include the } \\
\text { following capabilities: } \\
\text { 2. Calculation of whole-building (as a single } \\
\text { zone) sizing for the heating and cooling } \\
\text { equipment in the standard reference design } \\
\text { residence in accordance with Section M1401.3 of } \\
\text { the International Residential Code. }\end{array}$ & $\begin{array}{l}\text { 702.2 Energy cost performance levels } \\
\text { (Performance Path). Energy efficiency features } \\
\text { are implemented to achieve energy cost } \\
\text { performance that exceeds the } 2006 \text { IECC by the } \\
\text { following. A documented analysis using software } \\
\text { in accordance with } 2006 \text { IECC, Section 404, or } \\
\text { 2006 IECC Section } 506.2 \text { through 506.5, applied } \\
\text { as defined in the } 2006 \text { IECC, is required. }\end{array}$ & $\begin{array}{l}\text { ICC } 700 \text { requires documentation in accordance } \\
\text { with } 2006 \text { IECC if a project follows the } \\
\text { performance path. The requirement in the } \\
2006 \text { IECC meets the requirement of the } 2009 \\
\text { IECC. }\end{array}$ \\
\hline Performance & $\begin{array}{l}\text { 405.6 Calculation } \\
\text { software tools. } 405.6 .1 \\
\text { Minimum } \\
\text { capabilities.(3) }\end{array}$ & $\begin{array}{l}\text { Calculation procedures ... and shall include the } \\
\text { following capabilities: } \\
\text { 3. Calculations that account for the effects of } \\
\text { indoor and outdoor temperatures and part-load } \\
\text { ratios on the performance of heating, ventilating } \\
\text { and air-conditioning equipment based on climate } \\
\text { and equipment sizing. }\end{array}$ & $\begin{array}{l}\text { 702.2 Energy cost performance levels } \\
\text { (Performance Path). Energy efficiency features } \\
\text { are implemented to achieve energy cost } \\
\text { performance that exceeds the } 2006 \text { IECC by the } \\
\text { following. A documented analysis using software } \\
\text { in accordance with } 2006 \text { IECC, Section 404, or } \\
2006 \text { IECC Section } 506.2 \text { through 506.5, applied } \\
\text { as defined in the } 2006 \text { IECC, is required. }\end{array}$ & $\begin{array}{l}\text { ICC } 700 \text { requires documentation in accordance } \\
\text { with } 2006 \text { IECC if a project follows the } \\
\text { performance path. The requirement in the } \\
2006 \text { IECC meets the requirement of the } 2009 \\
\text { IECC. }\end{array}$ \\
\hline Performance & $\begin{array}{l}\text { 405.6 Calculation } \\
\text { software tools. } 405.6 .1 \\
\text { Minimum } \\
\text { capabilities.(4) }\end{array}$ & $\begin{array}{l}\text { Calculation procedures ... and shall include the } \\
\text { following capabilities: } \\
\text { 4. Printed code official inspection checklist } \\
\text { listing each of the proposed design component } \\
\text { characteristics from Table 405.5.2(1) determined } \\
\text { by the analysis to provide compliance, along } \\
\text { with their respective performance ratings (e.g., } \\
\text { R-value, U-factor, SHGC, HSPF, AFUE, SEER, } \\
\text { EF, etc.). }\end{array}$ & $\begin{array}{l}\text { 702.2 Energy cost performance levels } \\
\text { (Performance Path). Energy efficiency features } \\
\text { are implemented to achieve energy cost } \\
\text { performance that exceeds the } 2006 \text { IECC by the } \\
\text { following. A documented analysis using software } \\
\text { in accordance with } 2006 \text { IECC, Section 404, or } \\
2006 \text { IECC Section } 506.2 \text { through 506.5, applied } \\
\text { as defined in the } 2006 \text { IECC, is required. }\end{array}$ & $\begin{array}{l}\text { ICC } 700 \text { requires documentation in accordance } \\
\text { with } 2006 \text { IECC if a project follows the } \\
\text { performance path. The requirement in the } \\
2006 \text { IECC meets the requirement of the } 2009 \\
\text { IECC. }\end{array}$ \\
\hline Performance & $\begin{array}{l}405.6 \text { Calculation } \\
\text { software tools. } 405.6 .2\end{array}$ & $\begin{array}{l}\text { Performance analysis tools meeting the } \\
\text { applicable sections of Section } 405 \text { shall be }\end{array}$ & $\begin{array}{l}\text { 702.2 Energy cost performance levels } \\
\text { (Performance Path). Energy efficiency features }\end{array}$ & $\begin{array}{l}\text { ICC } 700 \text { requires documentation in accordance } \\
\text { with } 2006 \text { IECC if a project follows the }\end{array}$ \\
\hline
\end{tabular}

B.16 


\begin{tabular}{|c|c|c|c|c|}
\hline $\begin{array}{c}\text { Requirement } \\
\text { Category }\end{array}$ & $\begin{array}{c}\text { IECC Requirement } \\
\text { Reference }\end{array}$ & IECC 2009 & ICC-700 & Comments \\
\hline & Specific approval. & $\begin{array}{l}\text { permitted to be approved. Tools are permitted to } \\
\text { be approved based on meeting a specified } \\
\text { threshold for a jurisdiction. The code official } \\
\text { shall be permitted to approve tools for a } \\
\text { specified application or limited scope. }\end{array}$ & $\begin{array}{l}\text { are implemented to achieve energy cost } \\
\text { performance that exceeds the } 2006 \text { IECC by the } \\
\text { following. A documented analysis using software } \\
\text { in accordance with } 2006 \text { IECC, Section 404, or } \\
2006 \text { IECC Section } 506.2 \text { through 506.5, applied } \\
\text { as defined in the } 2006 \text { IECC, is required. }\end{array}$ & $\begin{array}{l}\text { performance path. The requirement in the } \\
2006 \text { IECC meets the requirement of the } 2009 \\
\text { IECC. }\end{array}$ \\
\hline Performance & $\begin{array}{l}\text { 405.6 Calculation } \\
\text { software tools. } 405.6 .3 \\
\text { Input values. }\end{array}$ & $\begin{array}{l}\text { When calculations require input values not } \\
\text { specified by Sections } 402,403,404 \text { and } 405 \text {, } \\
\text { those input values shall be taken from an } \\
\text { approved source. }\end{array}$ & $\begin{array}{l}\text { 702.2 Energy cost performance levels } \\
\text { (Performance Path). Energy efficiency features } \\
\text { are implemented to achieve energy cost } \\
\text { performance that exceeds the } 2006 \text { IECC by the } \\
\text { following. A documented analysis using software } \\
\text { in accordance with } 2006 \text { IECC, Section 404, or } \\
\text { IECC Section 506.2 through 506.5, applied as } \\
\text { defined in the IECC, is required. }\end{array}$ & $\begin{array}{l}\text { ICC } 700 \text { requires documentation in accordance } \\
\text { with } 2006 \text { IECC if a project follows the } \\
\text { performance path. The requirement in the } \\
2006 \text { IECC meets the requirement of the } 2009 \\
\text { IECC. }\end{array}$ \\
\hline
\end{tabular}


Appendix C

\section{LEED for Homes Certified Level Mapping}




\begin{tabular}{|c|c|c|c|c|}
\hline $\begin{array}{l}\text { Requirement } \\
\text { Category }\end{array}$ & $\begin{array}{c}\text { IECC } \\
\begin{array}{c}\text { Requirement } \\
\text { Reference }\end{array} \\
\end{array}$ & IECC 2009 & LEED for Homes & Comments \\
\hline Prescriptive & $\begin{array}{l}\text { 402.1.1 Insulation } \\
\text { and fenestration } \\
\text { criteria. }\end{array}$ & $\begin{array}{l}\text { The building thermal envelope shall meet } \\
\text { the requirements of Table } 402.1 .1 \text { based on } \\
\text { the climate zone specified in Chapter } 3 \text {. }\end{array}$ & $\begin{array}{l}\text { EA 2: Insulation - Prescriptive Path } \\
\text { Prerequisite 2.1 Basic Insulation (Mandatory). Meet all } \\
\text { the following requirements: } \\
\text { a) Install insulation that meets or exceeds the R-value } \\
\text { requirements listed in Chapter } 4 \text { of the } 2004 \\
\text { International Energy Conservation Code. } \\
\text { EA 4: Windows - Prescriptive Path } \\
\text { Prerequisite } 4.1 \text { Good Windows (Mandatory). Meet all } \\
\text { of the following requirements...design and install } \\
\text { windows and glass doors that have NFRC ratings that } \\
\text { meet or exceed the window requirements of the } \\
\text { ENERGY STAR for Homes national Builder Option } \\
\text { Package (Table 1). } \\
\text { Credit } 4.2 \text { Enhanced Windows (Optional). Design } \\
\text { and install windows and glass doors...that exceed...Table } \\
1 . \\
\text { OR } \\
\text { Credit 4.3 Exceptional Windows (Optional). Design } \\
\text { and install windows and glass doors...that substantially } \\
\text { exceed...Table 1. }\end{array}$ & $\begin{array}{l}\text { LEED for Homes requires compliance with the } \\
2004 \text { IECC. Table } 402.1 \text { of the } 2004 \text { IECC } \\
\text { meets or exceeds Table } 402.1 .1 \text { for all R-value } \\
\text { requirements EXCEPT Mass Walls and } \\
\text { Basement Walls. Table } 402.1 .2 \text { meets or } \\
\text { exceeds Table } 402.1 .3 \text { for all equivalent } U \text { - } \\
\text { factor requirements EXCEPT Floors and } \\
\text { Basement Walls. } \\
\text { Under LEED for Homes prerequisite 4.1, homes } \\
\text { in the Northern or North Central zones meet the } \\
\text { IECC requirements for fenestration U-factor } \\
\text { and SHGC. Homes in the South Central and } \\
\text { Southern zones meet the fenestration U-factor } \\
\text { requirements but not the SHGC requirements. } \\
\text { If homes in the South Central or Southern zones } \\
\text { achieve the optional LEED for Homes points } \\
\text { under Credit 4.3, the IECC SHGC requirements } \\
\text { will be met. }\end{array}$ \\
\hline Prescriptive & $\begin{array}{l}\text { 402.1.2 R-value } \\
\text { computation. }\end{array}$ & $\begin{array}{l}\text { Insulation material used in layers, such as } \\
\text { framing cavity insulation and insulating } \\
\text { sheathing, shall be summed to compute the } \\
\text { component R-value. The manufacturer's } \\
\text { settled R-value shall be used for blown } \\
\text { insulation. Computed R-values shall not } \\
\text { include an R-value for other building } \\
\text { materials or air films. }\end{array}$ & $\begin{array}{l}\text { EA 2: Insulation - Prescriptive Path } \\
\text { Prerequisite } 2.1 \text { Basic Insulation (Mandatory). Meet all } \\
\text { the following requirements: } \\
\text { a) Install insulation that meets or exceeds the R-value } \\
\text { requirements listed in Chapter } 4 \text { of the } 2004 \\
\text { International Energy Conservation Code. }\end{array}$ & $\begin{array}{l}\text { LEED for Homes requires compliance with the } \\
2004 \text { IECC R-value requirement, which meets } \\
\text { the } 2009 \text { IECC requirement. }\end{array}$ \\
\hline Prescriptive & $\begin{array}{l}\text { 402.1.3 U-factor } \\
\text { alternative. }\end{array}$ & $\begin{array}{l}\text { An assembly with a U-factor equal to or } \\
\text { less than that specified in Table } 402.1 .3 \\
\text { shall be permitted as an alternative to the R- } \\
\text { value in Table 402.1.1. }\end{array}$ & $\begin{array}{l}\text { EA 2: Insulation - Prescriptive Path } \\
\text { Prerequisite } 2.1 \text { Basic Insulation (Mandatory). Meet all } \\
\text { the following requirements: } \\
\text { a) Install insulation that meets or exceeds the R-value } \\
\text { requirements listed in Chapter } 4 \text { of the } 2004 \\
\text { International Energy Conservation Code. }\end{array}$ & $\begin{array}{l}\text { LEED for Homes requires compliance with the } \\
2004 \text { IECC. Table } 402.1 .3 \text { of the } 2004 \text { IECC } \\
\text { meets or exceeds Table } 402.1 .3 \text { of the } 2009 \\
\text { IECC for all equivalent U-factor requirements } \\
\text { EXCEPT Fenestration, Floors and Basement } \\
\text { Walls. }\end{array}$ \\
\hline Prescriptive & $\begin{array}{l}\text { 402.1.4 Total UA } \\
\text { alternative. }\end{array}$ & $\begin{array}{l}\text { If the total building thermal envelope UA... } \\
\text { is less than or equal to the total UA } \\
\text { resulting from using the U-factors in Table } \\
402.1 .3 . \ldots \text {, the building shall be considered } \\
\text { in compliance with Table } 402.1 .1 \text {. The UA } \\
\text { calculation shall be done using a method } \\
\text { consistent with the ASHRAE Handbook of } \\
\text { Fundamentals and shall include the thermal } \\
\text { bridging effects of framing materials. The } \\
\text { SHGC requirements shall be met in addition } \\
\text { to the UA compliance. }\end{array}$ & $\begin{array}{l}\text { EA 2: Insulation - Prescriptive Path } \\
\text { Prerequisite } 2.1 \text { Basic Insulation (Mandatory). Meet all } \\
\text { the following requirements: } \\
\text { a) Install insulation that meets or exceeds the R-value } \\
\text { requirements listed in Chapter } 4 \text { of the } 2004 \\
\text { International Energy Conservation Code. }\end{array}$ & $\begin{array}{l}\text { LEED for Homes requires compliance with the } \\
2004 \text { IECC. Table } 402.1 \text { of the } 2004 \text { IECC } \\
\text { meets or exceeds Table } 402.1 .1 \text { for all R-value } \\
\text { requirements EXCEPT Mass Walls and } \\
\text { Basement Walls. Table } 402.1 .2 \text { meets or } \\
\text { exceeds Table } 402.1 .3 \text { for all equivalent } U \text { - } \\
\text { factor requirements EXCEPT Floors and } \\
\text { Basement Walls. }\end{array}$ \\
\hline
\end{tabular}




\begin{tabular}{|c|c|c|c|c|}
\hline $\begin{array}{l}\text { Requirement } \\
\text { Category }\end{array}$ & $\begin{array}{c}\text { IECC } \\
\text { Requirement } \\
\text { Reference } \\
\end{array}$ & IECC 2009 & LEED for Homes & Comments \\
\hline Prescriptive & $\begin{array}{l}402.2 \text { Specific } \\
\text { insulation } \\
\text { requirements. } \\
402.2 .1 \text { Ceilings } \\
\text { with attic spaces. }\end{array}$ & $\begin{array}{l}\text { When Section } 402.1 .1 \text { would require R-38 } \\
\text { in the ceiling, R- } 30 \text { shall be deemed to } \\
\text { satisfy the requirement for R-38 whenever } \\
\text { the full height of uncompressed R-30 } \\
\text { insulation extends over the wall top plate at } \\
\text { the eaves. Similarly, R-38 shall be deemed } \\
\text { to satisfy the requirements for R- } 49 \text { where } \\
\text { ever the full height of uncompressed R-38 } \\
\text { insulation extends over the top plate at the } \\
\text { eaves. This reduction shall not apply to the } \\
\text { U-factor alternative approach in Section } \\
\text { 402.1.3 and the total UA alternative in } \\
\text { Section } 402.1 .4 \text {. }\end{array}$ & $\begin{array}{l}\text { EA 2: Insulation - Prescriptive Path } \\
\text { Prerequisite } 2.1 \text { Basic Insulation (Mandatory). Meet all } \\
\text { the following requirements: } \\
\text { a) Install insulation that meets or exceeds the R-value } \\
\text { requirements listed in Chapter } 4 \text { of the } 2004 \\
\text { International Energy Conservation Code. }\end{array}$ & $\begin{array}{l}\text { LEED for Homes requires compliance with the } \\
2004 \text { IECC R-value requirements, which meets } \\
\text { the } 2009 \text { IECC requirements. }\end{array}$ \\
\hline Prescriptive & $\begin{array}{l}402.2 \text { Specific } \\
\text { insulation } \\
\text { requirements. } \\
\text { 402.2.2 Ceilings } \\
\text { without attic } \\
\text { spaces. }\end{array}$ & $\begin{array}{l}\text { Where Section } 402.1 .1 \text { would require } \\
\text { insulation levels above R-30 and the design } \\
\text { often roof/ceiling assemble does not allow } \\
\text { sufficient space for the required insulation, } \\
\text { the minimum required insulation for such } \\
\text { roof/ceiling assemblies shall be R-30. This } \\
\text { reduction of insulation from the } \\
\text { requirements of Section } 402.1 .1 \text { shall be } \\
\text { limited to } 500 \text { square feet of } 20 \text { percent of } \\
\text { the total insulated ceiling area, whichever is } \\
\text { less. This reduction shall not apply to the } \\
\text { U-factor alternative approach in Section } \\
402.1 .3 \text { and the total UA alternative in } \\
\text { Section 4-2.1.4. }\end{array}$ & $\begin{array}{l}\text { EA 2: Insulation - Prescriptive Path } \\
\text { Prerequisite } 2.1 \text { Basic Insulation (Mandatory). Meet all } \\
\text { the following requirements: } \\
\text { a) Install insulation that meets or exceeds the R-value } \\
\text { requirements listed in Chapter } 4 \text { of the } 2004 \\
\text { International Energy Conservation Code. }\end{array}$ & $\begin{array}{l}\text { LEED for Homes requires compliance with the } \\
2004 \text { IECC R-value requirements, which meets } \\
\text { the } 2009 \text { IECC requirements. }\end{array}$ \\
\hline Prescriptive & $\begin{array}{l}\text { 402.2 Specific } \\
\text { insulation } \\
\text { requirements. } \\
\text { 402.2.3 Access } \\
\text { hatches and doors. }\end{array}$ & $\begin{array}{l}\text { Access doors from conditioned spaces to } \\
\text { unconditioned spaces (e.g., attics and crawl } \\
\text { spaces) shall be weatherstripped and } \\
\text { insulated to a level equivalent to the } \\
\text { insulation on the surrounding surfaces. } \\
\text { Access shall be provided to all equipment } \\
\text { that prevents damaging or compressing the } \\
\text { insulation. A wood framed or equivalent } \\
\text { baffle or retainer is required to be provided } \\
\text { when loose fill insulation is installed, the } \\
\text { purpose of which is to prevent the loose fill } \\
\text { insulation from spilling into the living space } \\
\text { when the attic access is opened, and to } \\
\text { provide a permanent means of maintaining } \\
\text { the installed R-value of the loose fill } \\
\text { insulation. }\end{array}$ & $\begin{array}{l}\text { EA 2: Insulation - Prescriptive Path } \\
\text { Prerequisite } 2.1 \text { Basic Insulation (Mandatory). Meet all } \\
\text { the following requirements: } \\
\text { a) Install insulation that meets or exceeds the R-value } \\
\text { requirements listed in Chapter } 4 \text { of the } 2004 \\
\text { International Energy Conservation Code. }\end{array}$ & $\begin{array}{l}\text { LEED for Homes requires compliance with the } \\
2004 \text { IECC. Access hatches and doors are not } \\
\text { explicitly mentioned in } 2004 \text { IECC. }\end{array}$ \\
\hline Prescriptive & $\begin{array}{l}402.2 \text { Specific } \\
\text { insulation } \\
\text { requirements. }\end{array}$ & $\begin{array}{l}\text { Mass walls for the purposes of this chapter } \\
\text { shall be considered above-grade walls of } \\
\text { concrete block, concrete, insulated concrete }\end{array}$ & $\begin{array}{l}\text { EA 2: Insulation - Prescriptive Path } \\
\text { Prerequisite } 2.1 \text { Basic Insulation (Mandatory). Meet } \\
\text { all the following requirements: }\end{array}$ & $\begin{array}{l}\text { LEED for Homes requires compliance with the } \\
2004 \text { IECC R-value requirements, which meets } \\
\text { the } 2009 \text { IECC requirements. }\end{array}$ \\
\hline
\end{tabular}




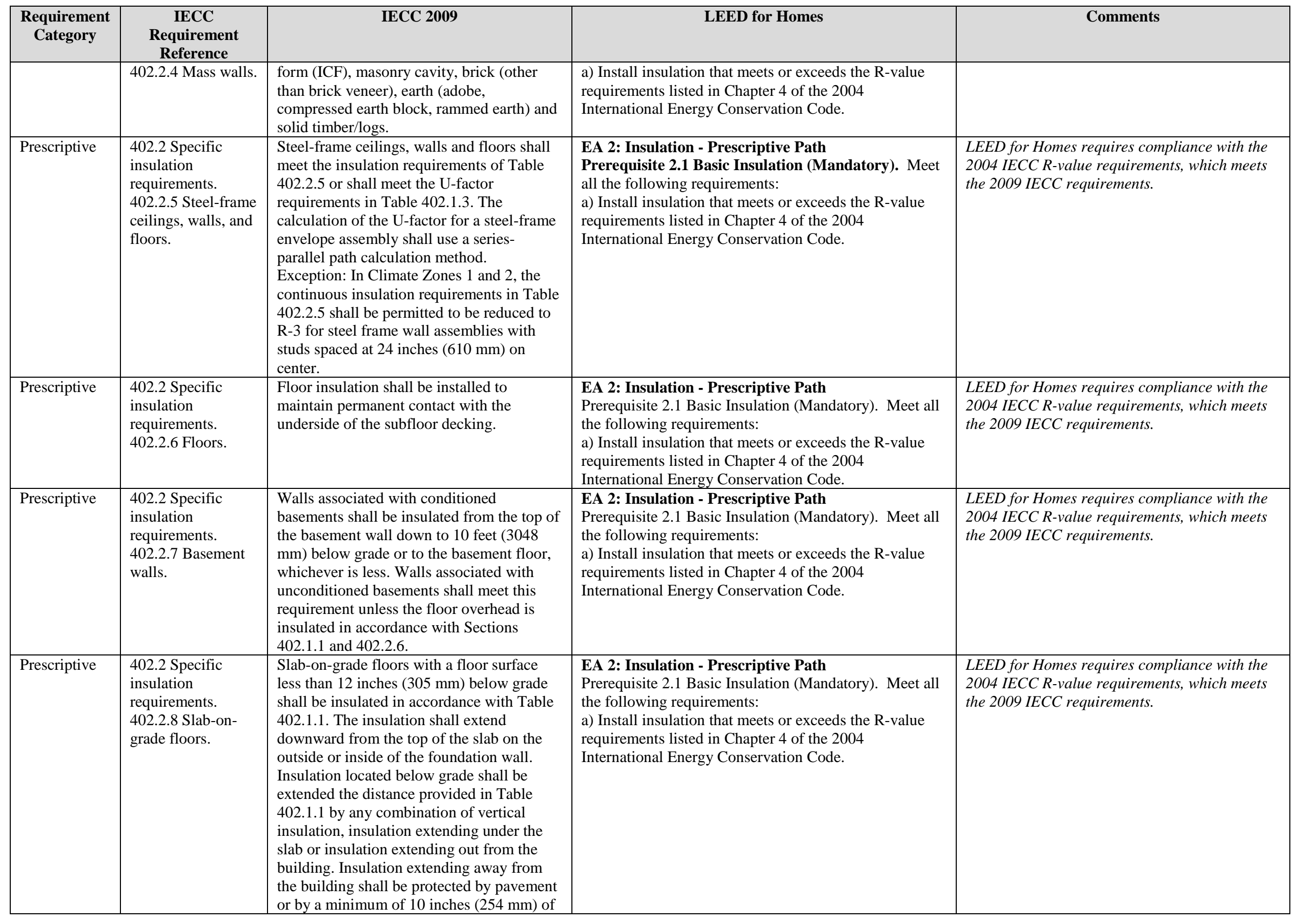




\begin{tabular}{|c|c|c|c|c|}
\hline $\begin{array}{c}\text { Requirement } \\
\text { Category }\end{array}$ & $\begin{array}{c}\text { IECC } \\
\text { Requirement } \\
\text { Reference }\end{array}$ & IECC 2009 & LEED for Homes & Comments \\
\hline & & $\begin{array}{l}\text { soil. The top edge of the insulation installed } \\
\text { between the exterior wall and the edge of } \\
\text { the interior slab shall be permitted to be cut } \\
\text { at a } 45 \text {-degree }(0.79 \text { rad) angle away from } \\
\text { the exterior wall. Slab-edge insulation is not } \\
\text { required in jurisdictions designated by the } \\
\text { code official as having a very heavy termite } \\
\text { infestation. }\end{array}$ & & \\
\hline Prescriptive & $\begin{array}{l}402.2 \text { Specific } \\
\text { insulation } \\
\text { requirements. } \\
402.2 .9 \text { Crawl } \\
\text { space walls. }\end{array}$ & $\begin{array}{l}\text { As an alternative to insulating floors over } \\
\text { crawl spaces, crawl space walls shall be } \\
\text { permitted to be insulated when the crawl } \\
\text { space is not vented to the outside. Crawl } \\
\text { space wall insulation shall be permanently } \\
\text { fastened to the wall and extend downward } \\
\text { from the floor to the finished grade level } \\
\text { and then vertically and/or horizontally for at } \\
\text { least an additional } 24 \text { inches ( } 610 \text { mm). } \\
\text { Exposed earth in unvented crawl space } \\
\text { foundations shall be covered with a } \\
\text { continuous Class I vapor retarder in } \\
\text { accordance with the International Building } \\
\text { Code. All joints of the vapor retarder shall } \\
\text { overlap by } 6 \text { inches ( } 153 \text { mm) and be sealed } \\
\text { or taped. The edges of the vapor retarder } \\
\text { shall extend at least } 6 \text { inches (153 mm) up } \\
\text { the stem wall and shall be attached to the } \\
\text { stem wall. }\end{array}$ & $\begin{array}{l}\text { EA 2: Insulation - Prescriptive Path } \\
\text { Prerequisite 2.1 Basic Insulation (Mandatory). Meet all } \\
\text { the following requirements: } \\
\text { a) Install insulation that meets or exceeds the R-value } \\
\text { requirements listed in Chapter } 4 \text { of the } 2004 \\
\text { International Energy Conservation Code. }\end{array}$ & $\begin{array}{l}\text { LEED for Homes requires compliance with the } \\
2004 \text { IECC R-value requirements, which meets } \\
\text { the } 2009 \text { IECC requirements. }\end{array}$ \\
\hline Prescriptive & $\begin{array}{l}\text { 402.2 Specific } \\
\text { insulation } \\
\text { requirements. } \\
\text { 402.2.10 Masonry } \\
\text { veneer. }\end{array}$ & $\begin{array}{l}\text { Insulation shall not be required on the } \\
\text { horizontal portion of the foundation that } \\
\text { supports a masonry veneer. }\end{array}$ & $\begin{array}{l}\text { EA 2: Insulation - Prescriptive Path } \\
\text { Prerequisite } 2.1 \text { Basic Insulation (Mandatory). Meet all } \\
\text { the following requirements: } \\
\text { a) Install insulation that meets or exceeds the R-value } \\
\text { requirements listed in Chapter } 4 \text { of the } 2004 \\
\text { International Energy Conservation Code. }\end{array}$ & $\begin{array}{l}\text { LEED for Homes requires compliance with the } \\
2004 \text { IECC R-value requirements, which meets } \\
\text { the } 2009 \text { IECC requirements. }\end{array}$ \\
\hline Prescriptive & $\begin{array}{l}\text { 402.2 Specific } \\
\text { insulation } \\
\text { requirements. } \\
\text { 402.2.11 Thermally } \\
\text { isolated sunroom } \\
\text { insulation. }\end{array}$ & $\begin{array}{l}\text { The minimum ceiling insulation R-values } \\
\text { shall be R-19 in Zones } 1 \text { through } 4 \text { and R- } \\
24 \text { in Zones } 5 \text { through } 8 \text {. The minimum wall } \\
\text { R-value shall be R-13 in all zones. New } \\
\text { wall(s) separating a sunroom from } \\
\text { conditioned space shall meet the building } \\
\text { thermal envelope requirements. }\end{array}$ & $\begin{array}{l}\text { EA 2: Insulation - Prescriptive Path } \\
\text { Prerequisite } 2.1 \text { Basic Insulation (Mandatory). Meet all } \\
\text { the following requirements: } \\
\text { a) Install insulation that meets or exceeds the R-value } \\
\text { requirements listed in Chapter } 4 \text { of the } 2004 \\
\text { International Energy Conservation Code. }\end{array}$ & $\begin{array}{l}\text { LEED for Homes requires compliance with the } \\
2004 \text { IECC R-value requirements, which meets } \\
\text { the } 2009 \text { IECC requirements. }\end{array}$ \\
\hline Prescriptive & $\begin{array}{l}\text { 402.3 Fenestration. } \\
\text { 402.3.1 U-factor. }\end{array}$ & $\begin{array}{l}\text { An area-weighted average of fenestration } \\
\text { products shall be permitted to satisfy the U- } \\
\text { factor requirements. }\end{array}$ & - & Not explicitly mentioned in LEED for Homes. \\
\hline Prescriptive & $\begin{array}{l}\text { 402.3 Fenestration. } \\
\text { 402.3.2-402.3.3. }\end{array}$ & $\begin{array}{l}\text { 402.3.2 Glazed fenestration SHGC. An } \\
\text { area-weighted average of fenestration } \\
\text { products more than } 50 \text { percent glazed shall }\end{array}$ & $\begin{array}{l}\text { EA 4: Windows - Prescriptive Path } \\
\text { Note: Up to } 0.75 \% \text { of the window-to-floor area may be } \\
\text { used for decorative glass or skylight area that does not }\end{array}$ & $\begin{array}{l}\text { LEED for Homes allows an exception for a } \\
\text { percentage of the window-to-floor area. IECC } \\
\text { allows an exception for up to } 15 \text { square feet of }\end{array}$ \\
\hline
\end{tabular}




\begin{tabular}{|c|c|c|c|c|}
\hline $\begin{array}{l}\text { Requirement } \\
\text { Category }\end{array}$ & $\begin{array}{c}\text { IECC } \\
\text { Requirement } \\
\text { Reference }\end{array}$ & IECC 2009 & LEED for Homes & Comments \\
\hline & & $\begin{array}{l}\text { be permitted to satisfy the SHGC } \\
\text { requirements. } \\
402.3 .3 \text { Glazed fenestration exemption. Up } \\
\text { to } 15 \text { square feet }(1.4 \mathrm{~m} 2) \text { of glazed } \\
\text { fenestration per dwelling unit shall be } \\
\text { permitted to be exempt from U-factor and } \\
\text { SHGC requirements in Section } 402.1 .1 \text {. } \\
\text { This exemption shall not apply to the U- } \\
\text { factor alternative approach in Section } \\
402.1 .3 \text { and the Total UA alternative in } \\
\text { Section } 402.1 .4 \text {. }\end{array}$ & meet the U-factor and SHGC requirements above. & $\begin{array}{l}\text { glazed fenestration per dwelling unit. The } \\
\text { exceptions are similar but not identical. IECC } \\
\text { requirements may or may not be met. }\end{array}$ \\
\hline Prescriptive & $\begin{array}{l}\text { 402.3 Fenestration. } \\
\text { 402.3.4 Opaque } \\
\text { door exemption. }\end{array}$ & $\begin{array}{l}\text { One side-hinged opaque door assembly up } \\
\text { to } 24 \text { square feet }(2.22 \mathrm{~m} 2) \text { in area is } \\
\text { exempted from the U-factor requirement in } \\
\text { Section } 402.1 .1 \text {. This exemption shall not } \\
\text { apply to the U-factor alternative approach in } \\
\text { Section } 402.1 .3 \text { and the total UA alternative } \\
\text { in Section } 402.1 .4 \text {. }\end{array}$ & - & Not explicitly mentioned in LEED for Homes. \\
\hline Prescriptive & $\begin{array}{l}\text { 402.3 Fenestration. } \\
\text { 402.3.5 Thermally } \\
\text { isolated sunroom } \\
\text { U-factor. }\end{array}$ & $\begin{array}{l}\text { For Zones } 4 \text { through } 8 \text {, the maximum } \\
\text { fenestration U-factor shall be } 0.50 \text { and the } \\
\text { maximum skylight U-factor shall be } 0.75 \text {. } \\
\text { New windows and doors separating the } \\
\text { sunroom from conditioned space shall meet } \\
\text { the building thermal envelope requirements. }\end{array}$ & - & Not explicitly mentioned in LEED for Homes. \\
\hline Prescriptive & $\begin{array}{l}\text { 402.3 Fenestration. } \\
\text { 402.3.6 } \\
\text { Replacement } \\
\text { fenestration. }\end{array}$ & $\begin{array}{l}\text { Where some or all of an existing } \\
\text { fenestration unit is replaced with a new } \\
\text { fenestration product, including sash and } \\
\text { glazing, the replacement fenestration unit } \\
\text { shall meet the applicable requirements for } \\
\text { U-factor and SHGC in Table 402.1.1. }\end{array}$ & - & Not explicitly mentioned in LEED for Homes. \\
\hline Mandatory & $\begin{array}{l}\text { 402.4 Air leakage. } \\
\text { 402.4.1 Building } \\
\text { thermal envelope. }\end{array}$ & $\begin{array}{l}\text { The building thermal envelope shall be } \\
\text { durably sealed to limit infiltration. The } \\
\text { sealing methods between dissimilar } \\
\text { materials shall allow for differential } \\
\text { expansion and contraction. The following } \\
\text { shall be caulked, gasketed, weatherstripped } \\
\text { or otherwise sealed with an air barrier } \\
\text { material, suitable film or solid material: }\end{array}$ & - & General guidance - not a unique requirement. \\
\hline Mandatory & $\begin{array}{l}\text { 402.4 Air leakage. } \\
\text { 402.4.1 Building } \\
\text { thermal envelope. } \\
\text { (1) }\end{array}$ & $\begin{array}{l}\text { The following shall be caulked, gasketed, } \\
\text { weatherstripped or otherwise sealed with an } \\
\text { air barrier material, suitable film or solid } \\
\text { material: } \\
\text { 1. All joints, seams and penetrations. }\end{array}$ & - & $\begin{array}{l}\text { LEED for Homes requires mandatory air } \\
\text { leakage testing, but does not mention specific air } \\
\text { sealing requirements. }\end{array}$ \\
\hline Mandatory & $\begin{array}{l}\text { 402.4 Air leakage. } \\
\text { 402.4.1 Building } \\
\text { thermal envelope. }\end{array}$ & $\begin{array}{l}\text { The following shall be caulked, gasketed, } \\
\text { weatherstripped or otherwise sealed with an } \\
\text { air barrier material, suitable film or solid }\end{array}$ & - & $\begin{array}{l}\text { LEED for Homes requires mandatory air } \\
\text { leakage testing, but does not mention specific air } \\
\text { sealing requirements. }\end{array}$ \\
\hline
\end{tabular}




\begin{tabular}{|c|c|c|c|c|}
\hline $\begin{array}{l}\text { Requirement } \\
\text { Category }\end{array}$ & $\begin{array}{c}\text { IECC } \\
\text { Requirement } \\
\text { Reference } \\
\end{array}$ & IECC 2009 & LEED for Homes & Comments \\
\hline & (2) & $\begin{array}{l}\text { material: } \\
\text { 2. Site-built windows, doors and skylights. }\end{array}$ & & \\
\hline Mandatory & $\begin{array}{l}\text { 402.4 Air leakage. } \\
\text { 402.4.1 Building } \\
\text { thermal envelope. } \\
\text { (3) }\end{array}$ & $\begin{array}{l}\text { The following shall be caulked, gasketed, } \\
\text { weatherstripped or otherwise sealed with an } \\
\text { air barrier material, suitable film or solid } \\
\text { material: } \\
\text { 3. Openings between window and door } \\
\text { assemblies and their respective jambs and } \\
\text { framing. }\end{array}$ & - & $\begin{array}{l}\text { LEED for Homes requires mandatory air } \\
\text { leakage testing, but does not mention specific air } \\
\text { sealing requirements. }\end{array}$ \\
\hline Mandatory & $\begin{array}{l}\text { 402.4 Air leakage. } \\
\text { 402.4.1 Building } \\
\text { thermal envelope. } \\
\text { (4) }\end{array}$ & $\begin{array}{l}\text { The following shall be caulked, gasketed, } \\
\text { weatherstripped or otherwise sealed with an } \\
\text { air barrier material, suitable film or solid } \\
\text { material: } \\
\text { 4. Utility penetrations. }\end{array}$ & - & $\begin{array}{l}\text { LEED for Homes requires mandatory air } \\
\text { leakage testing, but does not mention specific air } \\
\text { sealing requirements. }\end{array}$ \\
\hline Mandatory & $\begin{array}{l}\text { 402.4 Air leakage. } \\
\text { 402.4.1 Building } \\
\text { thermal envelope. } \\
\text { (5) }\end{array}$ & $\begin{array}{l}\text { The following shall be caulked, gasketed, } \\
\text { weatherstripped or otherwise sealed with an } \\
\text { air barrier material, suitable film or solid } \\
\text { material: } \\
\text { 5. Dropped ceilings or chases adjacent to } \\
\text { the thermal envelope. }\end{array}$ & - & $\begin{array}{l}\text { LEED for Homes requires mandatory air } \\
\text { leakage testing, but does not mention specific air } \\
\text { sealing requirements. }\end{array}$ \\
\hline Mandatory & $\begin{array}{l}\text { 402.4 Air leakage. } \\
\text { 402.4.1 Building } \\
\text { thermal envelope. } \\
\text { (6) }\end{array}$ & $\begin{array}{l}\text { The following shall be caulked, gasketed, } \\
\text { weatherstripped or otherwise sealed with an } \\
\text { air barrier material, suitable film or solid } \\
\text { material: } \\
6 \text {. Knee walls. }\end{array}$ & - & $\begin{array}{l}\text { LEED for Homes requires mandatory air } \\
\text { leakage testing, but does not mention specific air } \\
\text { sealing requirements. }\end{array}$ \\
\hline Mandatory & $\begin{array}{l}\text { 402.4 Air leakage. } \\
\text { 402.4.1 Building } \\
\text { thermal envelope. } \\
\text { (7) }\end{array}$ & $\begin{array}{l}\text { The following shall be caulked, gasketed, } \\
\text { weatherstripped or otherwise sealed with an } \\
\text { air barrier material, suitable film or solid } \\
\text { material: } \\
\text { 7. Walls and ceilings separating a garage } \\
\text { from conditioned spaces. }\end{array}$ & - & $\begin{array}{l}\text { LEED for Homes requires mandatory air } \\
\text { leakage testing, but does not mention specific air } \\
\text { sealing requirements. }\end{array}$ \\
\hline Mandatory & $\begin{array}{l}\text { 402.4 Air leakage. } \\
\text { 402.4.1 Building } \\
\text { thermal envelope. } \\
\text { (8) }\end{array}$ & $\begin{array}{l}\text { The following shall be caulked, gasketed, } \\
\text { weatherstripped or otherwise sealed with an } \\
\text { air barrier material, suitable film or solid } \\
\text { material: } \\
8 \text {. Behind tubs and showers on exterior } \\
\text { walls. }\end{array}$ & - & $\begin{array}{l}\text { LEED for Homes requires mandatory air } \\
\text { leakage testing, but does not mention specific air } \\
\text { sealing requirements. }\end{array}$ \\
\hline Mandatory & $\begin{array}{l}\text { 402.4 Air leakage. } \\
\text { 402.4.1 Building } \\
\text { thermal envelope. } \\
\text { (10) }\end{array}$ & $\begin{array}{l}\text { The following shall be caulked, gasketed, } \\
\text { weatherstripped or otherwise sealed with an } \\
\text { air barrier material, suitable film or solid } \\
\text { material: }\end{array}$ & - & $\begin{array}{l}\text { LEED for Homes requires mandatory air } \\
\text { leakage testing, but does not mention specific air } \\
\text { sealing requirements. }\end{array}$ \\
\hline
\end{tabular}




\begin{tabular}{|c|c|c|c|c|}
\hline $\begin{array}{c}\text { Requirement } \\
\text { Category }\end{array}$ & $\begin{array}{c}\text { IECC } \\
\text { Requirement } \\
\text { Reference } \\
\end{array}$ & IECC 2009 & LEED for Homes & Comments \\
\hline & & 10. Attic access openings. & & \\
\hline Mandatory & $\begin{array}{l}\text { 402.4 Air leakage. } \\
\text { 402.4.1 Building } \\
\text { thermal envelope. } \\
\text { (11) }\end{array}$ & $\begin{array}{l}\text { The following shall be caulked, gasketed, } \\
\text { weatherstripped or otherwise sealed with an } \\
\text { air barrier material, suitable film or solid } \\
\text { material: } \\
\text { 11. Rim joist junction. }\end{array}$ & - & $\begin{array}{l}\text { LEED for Homes requires mandatory air } \\
\text { leakage testing, but does not mention specific air } \\
\text { sealing requirements. }\end{array}$ \\
\hline Mandatory & $\begin{array}{l}\text { 402.4 Air leakage. } \\
\text { 402.4.1 Building } \\
\text { thermal envelope. } \\
\text { (12) }\end{array}$ & $\begin{array}{l}\text { The following shall be caulked, gasketed, } \\
\text { weatherstripped or otherwise sealed with an } \\
\text { air barrier material, suitable film or solid } \\
\text { material: } \\
\text { 12. Other sources of infiltration. }\end{array}$ & - & $\begin{array}{l}\text { LEED for Homes requires mandatory air } \\
\text { leakage testing, but does not mention specific air } \\
\text { sealing requirements. }\end{array}$ \\
\hline Mandatory & $\begin{array}{l}\text { 402.4 Air leakage. } \\
\text { 402.4.2 Air sealing } \\
\text { and insulation. } \\
\text { 402.4.2.1 Testing } \\
\text { option. }\end{array}$ & $\begin{array}{l}\text { Building envelope air tightness and } \\
\text { insulation installation shall be demonstrated } \\
\text { to comply with one of the following options } \\
\text { given by Section } 402.4 .2 .1 \text { or } 402.4 .2 .2 \text { : } \\
402.4 .2 .1 \text { Testing option. Building envelope } \\
\text { tightness and insulation installation shall be } \\
\text { considered acceptable when tested air } \\
\text { leakage is less than seven air changes per } \\
\text { hour (ACH) when tested with a blower door } \\
\text { at a pressure of } 50 \text { pascals (1 psf). Testing } \\
\text { shall occur after rough in and after } \\
\text { installation of penetrations of the building } \\
\text { envelope, including penetrations for } \\
\text { utilities, plumbing, electrical, ventilation } \\
\text { and combustion appliances. } \\
\text { During testing: } \\
\text { 1. Exterior windows and doors, fireplace } \\
\text { and stove doors shall be closed, but not } \\
\text { sealed; } \\
\text { 2. Dampers shall be closed, but not sealed, } \\
\text { including exhaust, intake, makeup air, } \\
\text { backdraft and flue dampers; } \\
\text { 3. Interior doors shall be open; } \\
\text { 4. Exterior openings for continuous } \\
\text { ventilation systems and heat recovery } \\
\text { ventilators shall be closed and sealed; } \\
\text { 5. Heating and cooling system(s) shall be } \\
\text { turned off; } \\
\text { 6. HVAC ducts shall not be sealed; and } \\
\text { 7. Supply and return registers shall not be } \\
\text { sealed. }\end{array}$ & $\begin{array}{l}\text { EA 3: Air Infiltration - Prescriptive Path } \\
\text { Pre-requisite 3.1 (Mandatory). Reduced Envelope } \\
\text { Leakage. Meet the air leakage requirements shown in } \\
\text { Table 1. The air leakage rate must be tested and verified } \\
\text { by an energy rater. } \\
\text { Credit } 3.2 \text { (Optional). Greatly Reduced Envelope } \\
\text { Leakage. Meet the air leakage requirements shown in } \\
\text { Table 1. The air leakage rate must be tested and verified } \\
\text { by an energy rater. } \\
\text { OR } \\
\text { Credit } 3.3 \text { (Optional) Minimal Envelope Leakage. Meet } \\
\text { the air leakage requirements shown in Table } 1 \text {. The air } \\
\text { leakage rate must be tested and verified by an energy } \\
\text { rater. }\end{array}$ & $\begin{array}{l}\text { Mandatory maximum air changes per hour } \\
\text { (ACH) allowed in LEED for Homes Table } 1 \text { is } \\
\text { seven ACH50 for IECC Climate Zones 1-2. } \\
\text { Specified ACH are below seven for other } \\
\text { Climate Zones. The } 2009 \text { IECC requirement are } \\
\text { met. } \\
\text { Optional LEED for Homes points go beyond the } \\
\text { IECC requirements. }\end{array}$ \\
\hline Mandatory & $\begin{array}{l}\text { 402.4 Air leakage. } \\
\text { 402.4.2 Air sealing } \\
\text { and insulation. } \\
\text { 402.4.2.2 Visual }\end{array}$ & $\begin{array}{l}\text { Building envelope air tightness and } \\
\text { insulation installation shall be demonstrated } \\
\text { to comply with one of the following options } \\
\text { given by Section } 402.4 .2 .1 \text { or } 402.4 .2 .2 \text { : }\end{array}$ & - & $\begin{array}{l}\text { LEED for Homes meets alternative IECC } \\
\text { requirement in Section 402.4.2.1. }\end{array}$ \\
\hline
\end{tabular}




\begin{tabular}{|c|c|c|c|c|}
\hline $\begin{array}{l}\text { Requirement } \\
\text { Category }\end{array}$ & $\begin{array}{c}\text { IECC } \\
\text { Requirement } \\
\text { Reference }\end{array}$ & IECC 2009 & LEED for Homes & Comments \\
\hline & inspection option. & $\begin{array}{l}\text { 402.4.2.2 Visual inspection option. Building } \\
\text { envelope tightness and insulation } \\
\text { installation shall be considered acceptable } \\
\text { when the items listed in Table } 402.4 .2 \text {, } \\
\text { applicable to the method of construction, } \\
\text { are field verified. Where required by the } \\
\text { code official, an approved party } \\
\text { independent from the installer of the } \\
\text { insulation shall inspect the air barrier and } \\
\text { insulation. }\end{array}$ & & \\
\hline Mandatory & $\begin{array}{l}\text { 402.4 Air leakage. } \\
\text { 402.4.3 Fireplaces. }\end{array}$ & $\begin{array}{l}\text { New wood-burning fireplaces shall have } \\
\text { gasketed doors and outdoor combustion air. }\end{array}$ & $\begin{array}{l}\text { EQ 2: Combustion Venting - Prescriptive Path } \\
\text { Prerequisite 2.1 Basic Combustion Venting Measures } \\
\text { (Mandatory). Meet all the following requirements... } \\
\text { c) All fireplaces and woodstoves must have doors. } \\
\text { d) Space and water heating equipment that involves } \\
\text { combustion must meet one of the following... } \\
\text { i. it must be designed and installed with closed } \\
\text { combustion (i.e., sealed supply air and exhaust ducting } \\
\text { ii. it must be designed and installed with power-vented } \\
\text { exhaust; or } \\
\text { iii. it must be located in a detached utility building or } \\
\text { open-air facility. } \\
\text { Credit 2.2 Enhanced Combustion Venting Measures } \\
\text { (Optional). Install no fireplace or woodstove, or design } \\
\text { and install a fireplace or woodstove according to the } \\
\text { requirements in Table 1. }\end{array}$ & $\begin{array}{l}\text { LEED for Homes prerequisite partially meets } \\
\text { the } 2009 \text { IECC requirements. LEED for Homes } \\
\text { does not require gasketed doors. }\end{array}$ \\
\hline Mandatory & $\begin{array}{l}\text { 402.4 Air leakage. } \\
\text { 402.4.4 } \\
\text { Fenestration air } \\
\text { leakage. }\end{array}$ & $\begin{array}{l}\text { Windows, skylights and sliding glass doors } \\
\text { shall have an air infiltration rate of no more } \\
\text { than } 0.3 \mathrm{cfm} \text { per square foot }(1.5 \mathrm{~L} / \mathrm{s} / \mathrm{m} 2) \text {, } \\
\text { and swinging doors no more than } 0.5 \mathrm{cfm} \\
\text { per square foot }(2.6 \mathrm{~L} / \mathrm{s} / \mathrm{m} 2) \text {, when tested } \\
\text { according to NFRC } 400 \text { or } \\
\text { AAMA/WDMA/CSA } 101 / \mathrm{I} . S .2 / \mathrm{A} 440 \text { by an } \\
\text { accredited, independent laboratory and } \\
\text { listed and labeled by the manufacturer. } \\
\text { Exceptions: Site-built windows, skylights } \\
\text { and doors. }\end{array}$ & - & $\begin{array}{l}\text { LEED for Homes requires mandatory air } \\
\text { leakage testing, but does not mention specific } \\
\text { fenestration sealing requirements. }\end{array}$ \\
\hline
\end{tabular}




\begin{tabular}{|c|c|c|c|c|}
\hline $\begin{array}{l}\text { Requirement } \\
\text { Category }\end{array}$ & $\begin{array}{c}\text { IECC } \\
\text { Requirement } \\
\text { Reference } \\
\end{array}$ & IECC 2009 & LEED for Homes & Comments \\
\hline & & $\begin{array}{l}\text { movement from the conditioned space to } \\
\text { the ceiling cavity. All recessed luminaires } \\
\text { shall be sealed with a gasket or caulk } \\
\text { between the housing and the interior wall or } \\
\text { ceiling covering. }\end{array}$ & & \\
\hline Mandatory & $\begin{array}{l}402.5 \text { Maximum } \\
\text { fenestration U- } \\
\text { factor and SHGC. }\end{array}$ & $\begin{array}{l}\text { The area-weighted average maximum } \\
\text { fenestration U-factor permitted using trade- } \\
\text { offs from Section } 402.1 .4 \text { or } 404 \text { shall be } \\
0.48 \text { in Zones } 4 \text { and } 5 \text { and } 0.40 \text { in Zones } 6 \\
\text { through } 8 \text { for vertical fenestration, and } 0.75 \\
\text { in Zones } 4 \text { through } 8 \text { for skylights. The } \\
\text { area-weighted average maximum } \\
\text { fenestration SHGC permitted using trade- } \\
\text { offs from Section } 404 \text { in Zones } 1 \text { through } 3 \\
\text { shall be } 0.50 \text {. }\end{array}$ & - & $\begin{array}{l}\text { LEED for Homes requires compliance with } \\
\text { ENERGY STAR V2.0 and it does not explicitly } \\
\text { mention trade-offs. The } 2009 \text { IECC requirement } \\
\text { is not met. }\end{array}$ \\
\hline Mandatory & $\begin{array}{l}\text { 403.1 Controls. } \\
\text { 403.1.1 } \\
\text { Programmable } \\
\text { thermostat. }\end{array}$ & $\begin{array}{l}\text { At least one thermostat shall be provided } \\
\text { for each separate heating and cooling } \\
\text { system. } \\
403.1 .1 \text { Programmable thermostat. Where } \\
\text { the primary heating system is a forced-air } \\
\text { furnace, at least one thermostat per dwelling } \\
\text { unit shall be capable of controlling the } \\
\text { heating and cooling system on a daily } \\
\text { schedule to maintain different temperature } \\
\text { set points at different times of the day. This } \\
\text { thermostat shall include the capability to set } \\
\text { back or temporarily operate the system to } \\
\text { maintain zone temperatures down to } 55^{\circ} \mathrm{F} \\
\left(13^{\circ} \mathrm{C}\right) \text { or up to } 85^{\circ} \mathrm{F}\left(29^{\circ} \mathrm{C}\right) \text {. The } \\
\text { thermostat shall initially be programmed } \\
\text { with a heating temperature set point no } \\
\text { higher than } 70^{\circ} \mathrm{F}\left(21^{\circ} \mathrm{C}\right) \text { and a cooling } \\
\text { temperature set point no lower than } 78^{\circ} \mathrm{F} \\
\left(26^{\circ} \mathrm{C}\right) \text {. }\end{array}$ & $\begin{array}{l}\text { EA 6: Space Heating and Cooling Equipment - } \\
\text { Prescriptive Path } \\
\text { Prerequisite } 6.1 \text { (Mandatory). Good HVAC Design and } \\
\text { Installation. Meet each of the following requirements... } \\
\text { c) Install ENERGY STAR labeled programmable } \\
\text { thermostat (except heat pumps and hydronic systems). } \\
\text { Update (1/1/10): To meet EA 6.1(c), programmable } \\
\text { thermostats are no longer required to be ENERGY } \\
\text { STAR labeled. }\end{array}$ & $\begin{array}{l}\text { LEED for Homes prerequisite requires } \\
\text { installation of programmable thermostats. } \\
\text { Initially programmed set points are not } \\
\text { mentioned. The } 2009 \text { IECC requirement is } \\
\text { partially met. }\end{array}$ \\
\hline Mandatory & $\begin{array}{l}\text { 403.1 Controls. } \\
\text { 403.1.2 Heat pump } \\
\text { supplementary } \\
\text { heat. }\end{array}$ & $\begin{array}{l}\text { Heat pumps having supplementary electric- } \\
\text { resistance heat shall have controls that, } \\
\text { except during defrost, prevent supplemental } \\
\text { heat operation when the heat pump } \\
\text { compressor can meet the heating load. }\end{array}$ & $\begin{array}{l}\text { EA 6: Space Heating and Cooling Equipment - } \\
\text { Prescriptive Path } \\
\text { If a heat pump is installed with a programmable } \\
\text { thermostat, the thermostat must be equipped with } \\
\text { adaptive recovery. This technology enables the heating } \\
\text { equipment to gradually adjust when the thermostat } \\
\text { setting changes, preventing overdependence on the less } \\
\text { efficient backup heating system. }\end{array}$ & $\begin{array}{l}\text { LEED for Homes does not require } \\
\text { programmable thermostats for heat pumps. } \\
\text { However, if a programmable thermostat for a } \\
\text { heat pump is installed, it must include adaptive } \\
\text { recovery. Adaptive recovery is similar to the } \\
2009 \text { IECC requirements, but can still allow the } \\
\text { use of electric-resistance heat when the heat } \\
\text { pump meets the load. The } 2009 \text { IECC } \\
\text { requirement is partially met. }\end{array}$ \\
\hline Prescriptive & $\begin{array}{l}\text { 403.2 Ducts. } \\
\text { 403.2.1 Insulation. }\end{array}$ & $\begin{array}{l}\text { Supply ducts in attics shall be insulated to a } \\
\text { minimum of R- } 8 \text {. All other ducts shall be } \\
\text { insulated to a minimum of R- } 6 \text {. }\end{array}$ & $\begin{array}{l}\text { EA 5: Heating and Cooling Distribution System - } \\
\text { Prescriptive Path } \\
\text { A. Forced-Air Systems }\end{array}$ & $\begin{array}{l}\text { LEED for Homes prerequisite does not mention } \\
\text { higher insulation levels for supply ducts in } \\
\text { attics. The } 2009 \text { IECC requirement is partially }\end{array}$ \\
\hline
\end{tabular}




\begin{tabular}{|c|c|c|c|c|}
\hline $\begin{array}{l}\text { Requirement } \\
\text { Category }\end{array}$ & $\begin{array}{c}\text { IECC } \\
\text { Requirement } \\
\text { Reference } \\
\end{array}$ & IECC 2009 & LEED for Homes & Comments \\
\hline & & $\begin{array}{l}\text { Exception: Ducts or portions thereof located } \\
\text { completely inside the building thermal } \\
\text { envelope. }\end{array}$ & $\begin{array}{l}\text { Prerequisite } 5.1 \text { Reduced Distribution Losses } \\
\text { (Mandatory). Meet the following requirements...c) use } \\
\text { at least R-6 insulation around ducts in unconditioned } \\
\text { spaces. }\end{array}$ & met. \\
\hline Mandatory & $\begin{array}{l}\text { 403.2 Ducts. } \\
\text { 403.2.2 Sealing. }\end{array}$ & $\begin{array}{l}\text { All ducts, air handlers, filter boxes and } \\
\text { building cavities used as ducts shall be } \\
\text { sealed. Joints and seams shall comply with } \\
\text { Section M1601.4.1 of the International } \\
\text { Residential Code. }\end{array}$ & - & $\begin{array}{l}\text { LEED for Homes requires mandatory air } \\
\text { leakage testing, but does not mention specific } \\
\text { duct sealing requirements. }\end{array}$ \\
\hline Mandatory & $\begin{array}{l}\text { 403.2 Ducts. } \\
\text { 403.2.2 Sealing. (1- } \\
\text { 2) }\end{array}$ & $\begin{array}{l}\text { Duct tightness shall be verified by either of } \\
\text { the following: } \\
1 \text {. Post-construction test: Leakage to } \\
\text { outdoors shall be less than or equal to } 8 \mathrm{cfm} \\
\text { ( } 226.5 \mathrm{~L} / \mathrm{min}) \text { per } 100 \mathrm{ft} 2(9.29 \mathrm{~m} 2) \text { of } \\
\text { conditioned floor area or a total leakage less } \\
\text { than or equal to } 12 \mathrm{cfm}(12 \mathrm{~L} / \mathrm{min}) \text { per } 100 \\
\mathrm{ft} 2 \text { ( } 9.29 \mathrm{~m} 2) \text { of conditioned floor area } \\
\text { when tested at a pressure differential of } 0.1 \\
\text { inches w.g. ( } 25 \text { Pa) across the entire system, } \\
\text { including the manufacturer's air handler } \\
\text { enclosure. All register boots shall be taped } \\
\text { or otherwise sealed during the test. } \\
2 . \text { Rough-in test: Total leakage shall be less } \\
\text { than or equal to } 6 \text { cfm (169.9 L/min) per } \\
100 \mathrm{ft} 2 \text { ( } 9.29 \text { m2) of conditioned floor area } \\
\text { when tested at a pressure differential of } 0.1 \\
\text { inches w.g. ( } 25 \text { Pa) across the roughed in } \\
\text { system, including the manufacturer's air } \\
\text { handler enclosure. All register boots shall } \\
\text { be taped or otherwise sealed during the test. } \\
\text { If the air handler is not installed at the time } \\
\text { of the test, total leakage shall be less than or } \\
\text { equal to } 4 \text { cfm ( } 113.3 \mathrm{~L} / \text { min) per } 100 \mathrm{ft} 2 \\
\text { (9.29 m2) of conditioned floor area. } \\
\text { Exceptions: Duct tightness test is not } \\
\text { required if the air handler and all ducts are } \\
\text { located within conditioned space. }\end{array}$ & $\begin{array}{l}\text { EA 5: Heating and Cooling Distribution System - } \\
\text { Prescriptive Path } \\
\text { A. Forced-Air Systems } \\
\text { Prerequisite } 5.1 \text { Reduced Distribution Losses } \\
\text { (Mandatory). Meet the following requirements...a) } \\
\text { Limit duct air leakage rate to outside the conditioned } \\
\text { envelope. The tested duct leakage rate must be }<=4.0 \\
\text { cfm at } 25 \text { Pascals per } 100 \text { square feet of conditioned } \\
\text { floor area (for each installed system), verified by the } \\
\text { energy rater. Testing is waived if the home meets EA } \\
5.3 \text { (b) or (c). }\end{array}$ & $\begin{array}{l}\text { LEED for Homes prerequisite meets the } 2009 \\
\text { IECC requirement. } \\
\text { If a home does not have forced air systems (e.g., } \\
\text { hydronic systems), the requirement does not } \\
\text { apply. }\end{array}$ \\
\hline
\end{tabular}




\begin{tabular}{|c|c|c|c|c|}
\hline $\begin{array}{l}\text { Requirement } \\
\text { Category }\end{array}$ & $\begin{array}{c}\text { IECC } \\
\text { Requirement } \\
\text { Reference }\end{array}$ & IECC 2009 & LEED for Homes & Comments \\
\hline & & & wall cavity as the duct). & \\
\hline Mandatory & $\begin{array}{l}403.3 \text { Mechanical } \\
\text { system piping } \\
\text { insulation. }\end{array}$ & $\begin{array}{l}\text { Mechanical system piping capable of } \\
\text { carrying fluids above } 105^{\circ} \mathrm{F}\left(41^{\circ} \mathrm{C}\right) \text { or } \\
\text { below } 55^{\circ} \mathrm{F}\left(13^{\circ} \mathrm{C}\right) \text { shall be insulated to a } \\
\text { minimum of R-3. }\end{array}$ & $\begin{array}{l}\text { EA 6: Space Heating and Cooling Equipment - } \\
\text { Prescriptive Path } \\
\text { Credit } 6.3 \text { (Optional). Very High-Efficiency HVAC. } \\
\text { Design and install HVAC equipment that is substantially } \\
\text { better than the equipment required by the ENERGY } \\
\text { STAR Builder Option Package (Table 1). Any piping } \\
\text { designed as part of a heat pump system to carry water } \\
\text { that is well above (or below) the thermostatic } \\
\text { temperature settings in the home must have R-4 } \\
\text { insulation or greater. }\end{array}$ & $\begin{array}{l}\text { Optional - If the LEED for Homes points are } \\
\text { achieved, the IECC requirement will be met. }\end{array}$ \\
\hline Mandatory & $\begin{array}{l}\text { 403.4 Circulating } \\
\text { hot water systems. }\end{array}$ & $\begin{array}{l}\text { All circulating service hot water piping } \\
\text { shall be insulated to at least R-2. Circulating } \\
\text { hot water systems shall include an } \\
\text { automatic or readily accessible manual } \\
\text { switch that can turn off the hot water } \\
\text { circulating pump when the system is not in } \\
\text { use. }\end{array}$ & $\begin{array}{l}\text { EA 7: Water Heating } \\
\text { Credit } 7.1 \text { Efficient Hot Water Distribution (Optional - } \\
\text { Performance Path)...Select one of the following designs: } \\
\text { a) Structured plumbing system... } \\
\text { iv. The system must be designed with a push button } \\
\text { control in each full bathroom and the kitchen and an } \\
\text { automatic pump shut-off. } \\
\text { Credit } 7.2 \text { Pipe Insulation (Optional - Prescriptive Path). } \\
\text { All domestic hot water piping shall have R-4 insulation. } \\
\text { Insulation shall be properly installed on all piping } \\
\text { elbows to adequately insulate the } 90 \text {-degree bend. }\end{array}$ & $\begin{array}{l}\text { Optional - If the LEED for Homes points are } \\
\text { achieved, the } 2009 \text { IECC requirement will be } \\
\text { met. }\end{array}$ \\
\hline Mandatory & $\begin{array}{l}403.5 \text { Mechanical } \\
\text { ventilation. }\end{array}$ & $\begin{array}{l}\text { Outdoor air intakes and exhausts shall have } \\
\text { automatic or gravity dampers that close } \\
\text { when the ventilation system is not } \\
\text { operating. }\end{array}$ & - & Not explicitly mentioned in LEED for Homes. \\
\hline Mandatory & $\begin{array}{l}403.6 \text { Equipment } \\
\text { sizing. }\end{array}$ & $\begin{array}{l}\text { Heating and cooling equipment shall be } \\
\text { sized in accordance with Section M1401.3 } \\
\text { of the International Residential Code. }\end{array}$ & $\begin{array}{l}\text { EA 6: Space Heating and Cooling Equipment - } \\
\text { Prescriptive Path } \\
\text { Prerequisite 6.1 (Mandatory). Good HVAC Design and } \\
\text { Installation. Meet each of the following requirements: } \\
\text { a) Design and size HVAC equipment properly using } \\
\text { ACCA Manual J, the ASHRAE } 2001 \text { Handbook of } \\
\text { Fundamentals, or an equivalent computation procedure. } \\
\text { b) Install HVAC equipment that meets the requirements } \\
\text { of the ENERGY STAR for Homes national Builder } \\
\text { Option Package (Table 1). } \\
\text { c) Install ENERGY STAR labeled programmable } \\
\text { thermostat (except heat pumps and hydronic systems). } \\
\text { Credit } 6.2 \text { (Optional). High-Efficiency HVAC. Design } \\
\text { and install HVAC equipment that is better than the } \\
\text { equipment required by the ENERGY STAR Builder } \\
\text { Option Package (Table 1) } \\
\text { OR } \\
\text { Credit } 6.3 \text { (Optional). Very High-Efficiency HVAC. } \\
\text { Design and install HVAC equipment that is substantially } \\
\text { better than the equipment required by the ENERGY }\end{array}$ & $\begin{array}{l}\text { Mandatory - LEED for Homes requirement } \\
\text { meets the } 2009 \text { IECC requirement. } \\
\text { Optional LEED for Homes points go beyond the } \\
\text { IECC requirements. }\end{array}$ \\
\hline
\end{tabular}




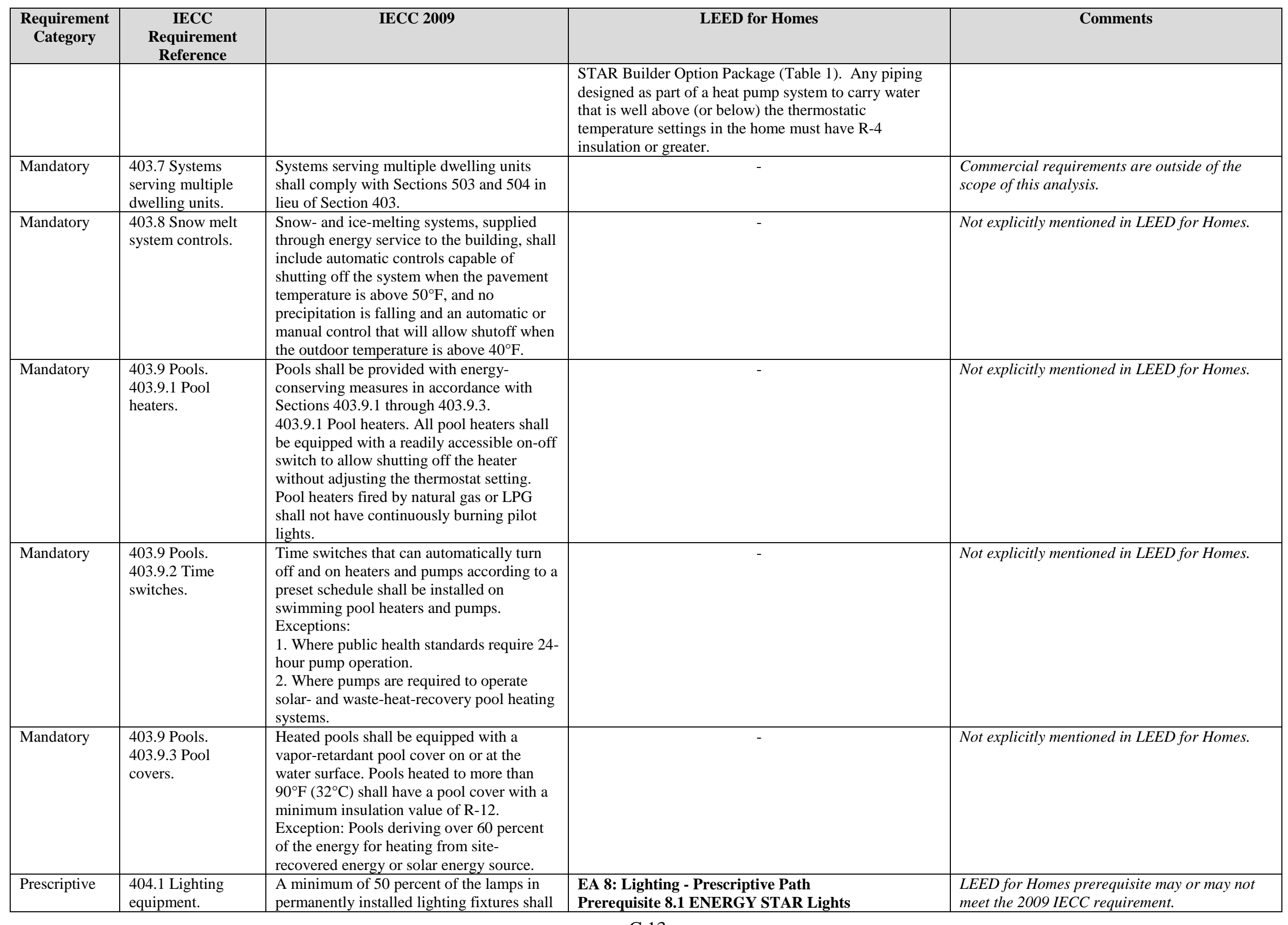

C.13 


\begin{tabular}{|c|c|c|c|c|}
\hline $\begin{array}{l}\text { Requirement } \\
\text { Category }\end{array}$ & $\begin{array}{c}\text { IECC } \\
\text { Requirement } \\
\text { Reference }\end{array}$ & IECC 2009 & LEED for Homes & Comments \\
\hline & & be high-efficacy lamps. & $\begin{array}{l}\text { (Mandatory). Install at least four ENERGY STAR } \\
\text { labeled light fixtures or ENERGY STAR labeled } \\
\text { compact fluorescent light bulbs (CFLs) in high-use } \\
\text { rooms (kitchen, dining room, living room, family room, } \\
\text { hallways). } \\
\text { Credit } 8.2 \text { Improved Lighting (Optional). Select and } \\
\text { install one or both of the following measures: } \\
\text { a) Indoor lighting. Install three additional ENERGY } \\
\text { STAR labeled light fixtures or ENERGY STAR labeled } \\
\text { compact fluorescent light bulbs (CFLs) in high-use } \\
\text { rooms. } \\
\text { b) Exterior lighting. All exterior lighting must have } \\
\text { either motion sensor controls or integrated photovoltaic } \\
\text { cells. } \\
\text { OR } \\
\text { Credit 8.3 Advanced Lighting Package (Optional). } \\
\text { Install ENERGY STAR Advanced Lighting } \\
\text { Package...consists of a minimum of 60\% ENERGY } \\
\text { STAR qualified hard-wired fixtures and 100\% } \\
\text { ENERGY STAR-qualified ceiling fans (if any) OR } \\
\text { Install ENERGY STAR labeled lamps in 80\% of the } \\
\text { fixtures throughout the home. ENERGY STAR labeled } \\
\text { CFLs are acceptable. All ceiling fans must be ENERGY } \\
\text { STAR labeled. }\end{array}$ & $\begin{array}{l}\text { If the points under Optional Credit } 8.3 \text { are } \\
\text { achieved, the IECC requirement will be met. }\end{array}$ \\
\hline Performance & $\begin{array}{l}405.2 \text { Mandatory } \\
\text { requirements. }\end{array}$ & $\begin{array}{l}\text { Compliance with this section requires that } \\
\text { the mandatory provisions identified in } \\
\text { Section } 401.2 \text { be met. All supply and return } \\
\text { ducts not completely inside the building } \\
\text { thermal envelope shall be insulated to a } \\
\text { minimum of R-6. }\end{array}$ & $\begin{array}{l}\text { EA 5: Heating and Cooling Distribution System - } \\
\text { Prescriptive Path } \\
\text { A. Forced-Air Systems } \\
\text { Prerequisite 5.1 Reduced Distribution Losses } \\
\text { (Mandatory). Meet the following requirements...c) use } \\
\text { at least R-6 insulation around ducts in unconditioned } \\
\text { spaces. }\end{array}$ & $\begin{array}{l}\text { LEED for Homes prerequisite meets the } 2009 \\
\text { IECC requirement. } \\
\text { If a home does not have forced air systems (e.g., } \\
\text { hydronic systems), the requirement does not } \\
\text { apply. }\end{array}$ \\
\hline Performance & $\begin{array}{l}405.3 \text { Performance- } \\
\text { based compliance. }\end{array}$ & $\begin{array}{l}\text { Compliance based on simulated energy } \\
\text { performance requires that a proposed } \\
\text { residence (proposed design) be shown to } \\
\text { have an annual energy cost that is less than } \\
\text { or equal to the annual energy cost of the } \\
\text { standard reference design. Energy prices } \\
\text { shall be taken from a source approved by } \\
\text { the code official, such as the Department of } \\
\text { Energy, Energy Information } \\
\text { Administration's State Energy Price and } \\
\text { Expenditure Report. Code officials shall be } \\
\text { permitted to require time-of-use pricing in } \\
\text { energy cost calculations. } \\
\text { Exception: The energy use based on source } \\
\text { energy expressed in Btu or Btu per square }\end{array}$ & $\begin{array}{l}\text { EA 1: Optimize Energy Performance - Performance } \\
\text { Path } \\
\text { Prerequisite } 1.1 \text { Performance of ENERGY STAR for } \\
\text { Homes. Meet the performance requirements of } \\
\text { ENERGY STAR for homes, including third-party } \\
\text { inspections. } \\
\text { Credit } 1.2 \text { Exceptional Energy Performance. Exceed the } \\
\text { performance of ENERGY STAR for Homes. } \\
\text { Clarification (1/1/10): The performance requirements of } \\
\text { Energy Star for Homes } 2006 \text { are published on the EPA } \\
\text { website and include: 1) HERS Index of } 80 \text { or lower in } \\
\text { climate zones 6-8 or HERS Index of } 85 \text { or lower in } \\
\text { climate zones 1-5; 2) completed Thermal Bypass } \\
\text { Inspection Checklist, including slab-edge insulation in }\end{array}$ & $\begin{array}{l}\text { ENERGY STAR for Homes requires a HERS } \\
\text { index of } 85 \text { to } 80 \text {, depending on the climate zone. } \\
\text { IECC } 2009 \text { requirements are equivalent to a } \\
\text { HERS index of } 85 \text { because it is } 15 \% \text { more } \\
\text { efficient than the } 2006 \text { IECC which would } \\
\text { receive a HERS index of } 100 \text {. However, } \\
\text { ENERGY STAR requirements do not fully } \\
\text { comply with the } 2009 \text { IECC because the } \\
\text { allowance for equipment efficiency trade-offs } \\
\text { contained in the Performance Path are not } \\
\text { allowed in the IECC 2009. }\end{array}$ \\
\hline
\end{tabular}




\begin{tabular}{|c|c|c|c|c|}
\hline $\begin{array}{c}\text { Requirement } \\
\text { Category }\end{array}$ & $\begin{array}{c}\text { IECC } \\
\text { Requirement } \\
\text { Reference } \\
\end{array}$ & IECC 2009 & LEED for Homes & Comments \\
\hline & & $\begin{array}{l}\text { foot of conditioned floor area shall be } \\
\text { permitted to be substituted for the energy } \\
\text { cost. The source energy multiplier for } \\
\text { electricity shall be } 3.16 \text {. The source energy } \\
\text { multiplier for fuels other than electricity } \\
\text { shall be } 1.1 \text {. }\end{array}$ & $\begin{array}{l}\text { climate zones } 4+; 3) \text { duct leakage of less than } 6 \text { CFM to } \\
\text { outdoors per } 100 \text { sq. ft.; 4) at least one Energy Star } \\
\text { qualified product (heating or cooling equipment; } \\
\text { windows; } 5 \text { or more labeled light fixtures, appliances, or } \\
\text { ventilation fans); 5) indoor and outdoor coils must be } \\
\text { matched, in accordance with AHRI standards; 6) } \\
\text { adaptive recovery for any programmable thermostats } \\
\text { installed in homes with a heat pump; and 7) maximum } \\
\text { oversizing limit for air conditioners and heat pumps is } \\
15 \% \text {, with the exception of heat pumps in Climate Zones } \\
5-8, \text { where maximum oversizing is } 25 \%) \text {. }\end{array}$ & \\
\hline Performance & $\begin{array}{l}405.4 \\
\text { Documentation. } \\
405.4 .1 \\
\text { Compliance } \\
\text { software tools. } \\
\end{array}$ & $\begin{array}{l}\text { Documentation verifying that the methods } \\
\text { and accuracy of the compliance software } \\
\text { tools conform to the provisions of this } \\
\text { section shall be provided to the code } \\
\text { official. }\end{array}$ & - & Not explicitly mentioned in LEED for Homes. \\
\hline Performance & $\begin{array}{l}405.4 \\
\text { Documentation. } \\
405.4 .2 \\
\text { Compliance } \\
\text { report.(1) }\end{array}$ & $\begin{array}{l}\text { The compliance documentation shall } \\
\text { include the following information: } \\
\text { 1. Address or other identification of the } \\
\text { residence; }\end{array}$ & - & Not explicitly mentioned in LEED for Homes. \\
\hline Performance & $\begin{array}{l}405.4 \\
\text { Documentation. } \\
405.4 .2 \\
\text { Compliance } \\
\text { report.(2) }\end{array}$ & $\begin{array}{l}\text { The compliance documentation shall } \\
\text { include the following information: } \\
\text { 2. An inspection checklist documenting the } \\
\text { building component characteristics of the } \\
\text { proposed design as listed in Table } \\
\text { 405.5.2(1). The inspection checklist shall } \\
\text { show results for both the standard reference } \\
\text { design and the proposed design, and shall } \\
\text { document all inputs entered by the user } \\
\text { necessary to reproduce the results; }\end{array}$ & - & Not explicitly mentioned in LEED for Homes. \\
\hline Performance & $\begin{array}{l}405.4 \\
\text { Documentation. } \\
405.4 .2 \\
\text { Compliance } \\
\text { report.(3) }\end{array}$ & $\begin{array}{l}\text { The compliance documentation shall } \\
\text { include the following information: } \\
\text { 3. Name of individual completing the } \\
\text { compliance report; and }\end{array}$ & - & Not explicitly mentioned in LEED for Homes. \\
\hline Performance & $\begin{array}{l}405.4 \\
\text { Documentation. } \\
405.4 .2 \\
\text { Compliance } \\
\text { report.(4) }\end{array}$ & $\begin{array}{l}\text { The compliance documentation shall } \\
\text { include the following information: } \\
\text { 4. Name and version of the compliance } \\
\text { software tool. } \\
\text { Exception: Multiple orientations. When an } \\
\text { otherwise identical building model is }\end{array}$ & - & Not explicitly mentioned in LEED for Homes. \\
\hline
\end{tabular}




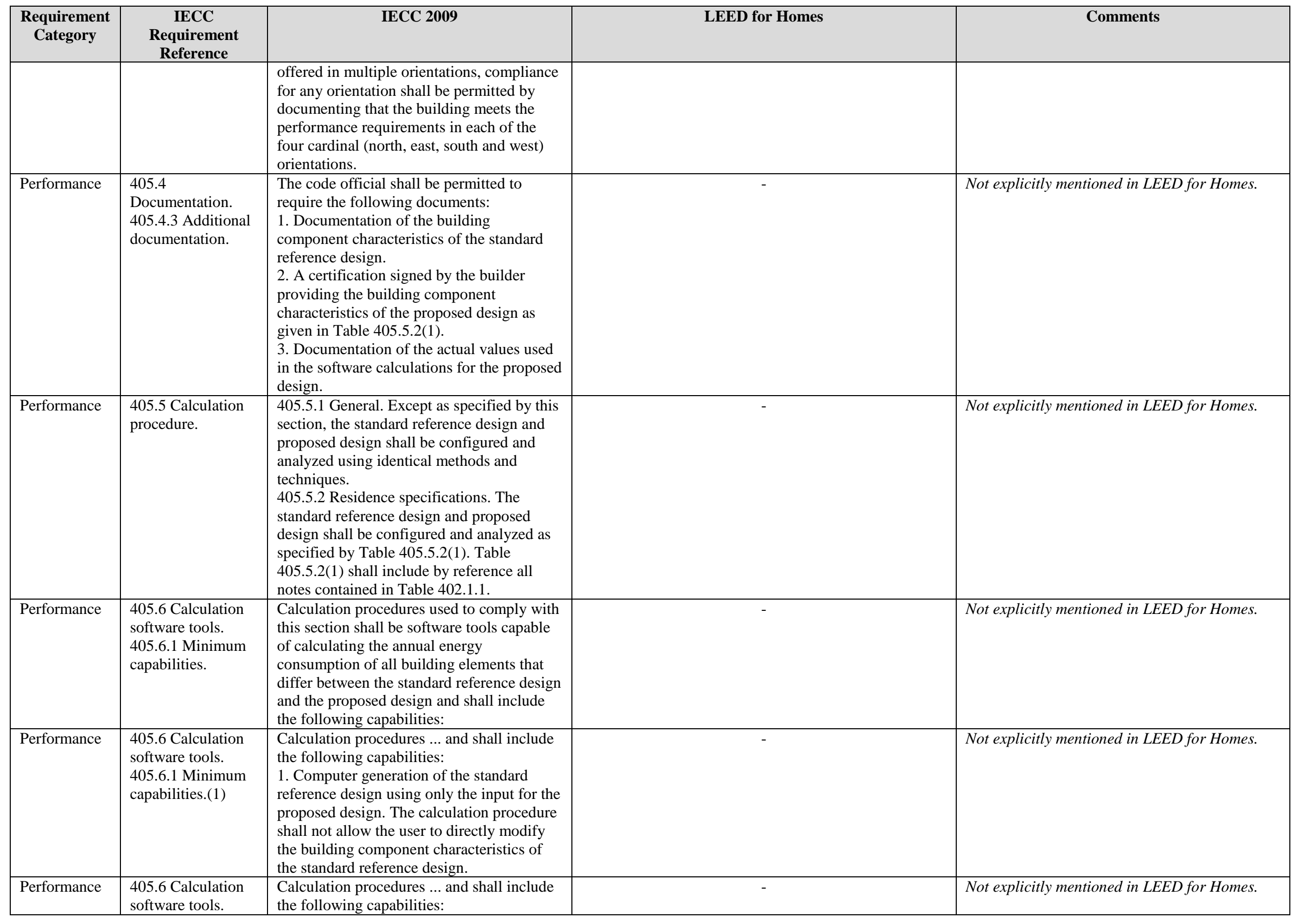




\begin{tabular}{|c|c|c|c|c|}
\hline $\begin{array}{l}\text { Requirement } \\
\text { Category }\end{array}$ & $\begin{array}{c}\text { IECC } \\
\text { Requirement } \\
\text { Reference }\end{array}$ & IECC 2009 & LEED for Homes & Comments \\
\hline & $\begin{array}{l}\text { 405.6.1 Minimum } \\
\text { capabilities.(2) }\end{array}$ & $\begin{array}{l}\text { 2. Calculation of whole-building (as a } \\
\text { single zone) sizing for the heating and } \\
\text { cooling equipment in the standard reference } \\
\text { design residence in accordance with Section } \\
\text { M1401.3 of the International Residential } \\
\text { Code. }\end{array}$ & & \\
\hline Performance & $\begin{array}{l}\text { 405.6 Calculation } \\
\text { software tools. } \\
\text { 405.6.1 Minimum } \\
\text { capabilities.(3) }\end{array}$ & $\begin{array}{l}\text { Calculation procedures ... and shall include } \\
\text { the following capabilities: } \\
\text { 3. Calculations that account for the effects } \\
\text { of indoor and outdoor temperatures and } \\
\text { part-load ratios on the performance of } \\
\text { heating, ventilating and air-conditioning } \\
\text { equipment based on climate and equipment } \\
\text { sizing. }\end{array}$ & - & Not explicitly mentioned in LEED for Homes. \\
\hline Performance & $\begin{array}{l}\text { 405.6 Calculation } \\
\text { software tools. } \\
\text { 405.6.1 Minimum } \\
\text { capabilities.(4) }\end{array}$ & $\begin{array}{l}\text { Calculation procedures ... and shall include } \\
\text { the following capabilities: } \\
\text { 4. Printed code official inspection checklist } \\
\text { listing each of the proposed design } \\
\text { component characteristics from Table } \\
\text { 405.5.2(1) determined by the analysis to } \\
\text { provide compliance, along with their } \\
\text { respective performance ratings (e.g., R- } \\
\text { value, U-factor, SHGC, HSPF, AFUE, } \\
\text { SEER, EF, etc.). }\end{array}$ & - & Not explicitly mentioned in LEED for Homes. \\
\hline Performance & $\begin{array}{l}\text { 405.6 Calculation } \\
\text { software tools. } \\
\text { 405.6.2 Specific } \\
\text { approval. }\end{array}$ & $\begin{array}{l}\text { Performance analysis tools meeting the } \\
\text { applicable sections of Section } 405 \text { shall be } \\
\text { permitted to be approved. Tools are } \\
\text { permitted to be approved based on meeting } \\
\text { a specified threshold for a jurisdiction. The } \\
\text { code official shall be permitted to approve } \\
\text { tools for a specified application or limited } \\
\text { scope. }\end{array}$ & - & Not explicitly mentioned in LEED for Homes. \\
\hline Performance & $\begin{array}{l}\text { 405.6 Calculation } \\
\text { software tools. } \\
\text { 405.6.3 Input } \\
\text { values. }\end{array}$ & $\begin{array}{l}\text { When calculations require input values not } \\
\text { specified by Sections } 402,403,404 \text { and } \\
405 \text {, those input values shall be taken from } \\
\text { an approved source. }\end{array}$ & - & Not explicitly mentioned in LEED for Homes. \\
\hline
\end{tabular}


Appendix D

\section{ENERGY STAR Version 2.0 Mapping}




\begin{tabular}{|c|c|c|c|c|}
\hline $\begin{array}{l}\text { Requirement } \\
\text { Category }\end{array}$ & $\begin{array}{c}\text { IECC } \\
\text { Requirement } \\
\text { Reference }\end{array}$ & IECC & ES2 & Comments \\
\hline Prescriptive & $\begin{array}{l}\text { 402.1.1 Insulation } \\
\text { and fenestration } \\
\text { criteria. }\end{array}$ & $\begin{array}{l}\text { The building thermal envelope shall meet } \\
\text { the requirements of Table } 402.1 .1 \text { based } \\
\text { on the climate zone specified in Chapter } 3 \text {. }\end{array}$ & $\begin{array}{l}\text { Prescriptive Path: The building thermal envelope must } \\
\text { meet the following requirements. Infiltration (ACH50): } \\
7 \text { in CZ's 1-2, } 6 \text { in CZ's 3-4, } 5 \text { in CZ's 5-7, and } 4 \text { in CZ } \\
\text { 8. And insulation levels must meet or exceed the } 2004 \\
\text { IRC, and a completed Thermal Bypass Inspection } \\
\text { checklist must be performed. Envelope leakage must be } \\
\text { determined by a RESNET- certified rater using a } \\
\text { RESNET- approved testing protocol. Insulation levels } \\
\text { of a home must meet or exceed Sections N1102.1 and } \\
\text { N1102.2 of the } 2004 \text { IRC. These sections allow for } \\
\text { compliance to be determined by meeting prescriptive } \\
\text { insulation requirements, by using U-factor alternatives, } \\
\text { or by using a total UA alternative. These sections also } \\
\text { provide guidance and exceptions that may be used. } \\
\text { However, note that the U-factor for steel-frame } \\
\text { envelope assemblies addressed in Section N1102.2.4 } \\
\text { shall be calculated using the ASHRAE zone method, or } \\
\text { a method providing equivalent results, and not a series- } \\
\text { parallel path calculation method as is stated in the code. } \\
\text { Additionally, Section N1102.2.2, which allows for the } \\
\text { reduction of ceiling insulation in space constrained } \\
\text { roof/ceiling assemblies, shall be limited to } 500 \text { sq. ft. or } \\
\text { 20\% of ceiling area, whichever is less. In all cases, } \\
\text { insulation shall be inspected to Grade } 1 \text { installation as } \\
\text { defined in the RESNET Standards by a RESNET- } \\
\text { certified rater. }\end{array}$ & $\begin{array}{l}\text { Prescriptive - The ENERGY STAR V2 insulation } \\
\text { and glazing value portions are lower than the } \\
\text { IECC } 2009 \text { requirement for all assembly types in } \\
\text { all Climate Zones, however, the ENERGY STAR V2 } \\
\text { air infiltration rates exceed the IECC } 2009 \\
\text { requirement. This results in overall performance } \\
\text { exceeding the } 2009 \text { IECC requirement. }\end{array}$ \\
\hline Prescriptive & $\begin{array}{l}\text { 402.1.2 R-value } \\
\text { computation. }\end{array}$ & $\begin{array}{l}\text { Insulation material used in layers, such as } \\
\text { framing cavity insulation and insulating } \\
\text { sheathing, shall be summed to compute the } \\
\text { component R-value. The manufacturer's } \\
\text { settled R-value shall be used for blown } \\
\text { insulation. Computed R-values shall not } \\
\text { include an R-value for other building } \\
\text { materials or air films. }\end{array}$ & $\begin{array}{l}\text { See alternative compliance path under } 2009 \text { IECC } \\
\text { section 402.1.4. }\end{array}$ & $\begin{array}{l}\text { ENERGY STAR V2 does not require specific } \\
\text { insulation R-values, however it has requirements } \\
\text { for total building thermal envelope UA thus it } \\
\text { meets the alternative IECC requirement (see below } \\
\text { description under Section 402.1.4). }\end{array}$ \\
\hline Prescriptive & $\begin{array}{l}\text { 402.1.3 U-factor } \\
\text { alternative. }\end{array}$ & $\begin{array}{l}\text { An assembly with a U-factor equal to or } \\
\text { less than that specified in Table } 402.1 .3 \\
\text { shall be permitted as an alternative to the } \\
\text { R-value in Table } 402.1 .1 \text {. }\end{array}$ & $\begin{array}{l}\text { Prescriptive Path: The building thermal envelope must } \\
\text { meet the following requirements. Infiltration (ACH50): } \\
7 \text { in CZ's 1-2, } 6 \text { in CZ's 3-4, } 5 \text { in CZ's 5-7, and } 4 \text { in CZ } \\
8 \text {. And insulation levels must meet or exceed the } 2004 \\
\text { IRC, and a completed Thermal Bypass Inspection } \\
\text { checklist must be performed. Envelope leakage must be } \\
\text { determined by a RESNET- certified rater using a } \\
\text { RESNET- approved testing protocol. Insulation levels } \\
\text { of a home must meet or exceed Sections N1102.1 and } \\
\text { N1102.2 of the } 2004 \text { IRC. These sections allow for } \\
\text { compliance to be determined by meeting prescriptive } \\
\text { insulation requirements, by using U-factor alternatives, }\end{array}$ & $\begin{array}{l}\text { Prescriptive Path - ENERGY STAR only meets a } \\
\text { portion of the IECC } 2009 \text { requirement. }\end{array}$ \\
\hline
\end{tabular}




\begin{tabular}{|c|c|c|c|c|}
\hline $\begin{array}{l}\text { Requirement } \\
\text { Category }\end{array}$ & $\begin{array}{c}\text { IECC } \\
\text { Requirement } \\
\text { Reference }\end{array}$ & IECC & ES2 & Comments \\
\hline & & & $\begin{array}{l}\text { or by using a total UA alternative. These sections also } \\
\text { provide guidance and exceptions that may be used. } \\
\text { However, note that the U-factor for steel-frame } \\
\text { envelope assemblies addressed in Section N1102.2.4 } \\
\text { shall be calculated using the ASHRAE zone method, or } \\
\text { a method providing equivalent results, and not a series- } \\
\text { parallel path calculation method as is stated in the code. } \\
\text { Additionally, Section N1102.2.2, which allows for the } \\
\text { reduction of ceiling insulation in space constrained } \\
\text { roof/ceiling assemblies, shall be limited to } 500 \text { sq. ft. or } \\
20 \% \text { of ceiling area, whichever is less. In all cases, } \\
\text { insulation shall be inspected to Grade } 1 \text { installation as } \\
\text { defined in the RESNET Standards by a RESNET- } \\
\text { certified rater. }\end{array}$ & \\
\hline Prescriptive & $\begin{array}{l}\text { 402.1.4 Total UA } \\
\text { alternative. }\end{array}$ & $\begin{array}{l}\text { If the total building thermal envelope } \\
\text { UA... is less than or equal to the total UA } \\
\text { resulting from using the U-factors in Table } \\
402.1 .3 \ldots \text {, the building shall be } \\
\text { considered in compliance with Table } \\
\text { 402.1.1. The UA calculation shall be done } \\
\text { using a method consistent with the } \\
\text { ASHRAE Handbook of Fundamentals and } \\
\text { shall include the thermal bridging effects } \\
\text { of framing materials. The SHGC } \\
\text { requirements shall be met in addition to } \\
\text { the UA compliance. }\end{array}$ & $\begin{array}{l}\text { Prescriptive Path: The building thermal envelope must } \\
\text { meet the following requirements. Infiltration (ACH50): } \\
7 \text { in CZ's 1-2, } 6 \text { in CZ's 3-4, } 5 \text { in CZ's 5-7, and } 4 \text { in CZ } \\
\text { 8. And insulation levels must meet or exceed the } 2004 \\
\text { IRC, and a completed Thermal Bypass Inspection } \\
\text { checklist must be performed. Envelope leakage must be } \\
\text { determined by a RESNET- certified rater using a } \\
\text { RESNET- approved testing protocol. Insulation levels } \\
\text { of a home must meet or exceed Sections N1102.1 and } \\
\text { N1102.2 of the } 2004 \text { IRC. These sections allow for } \\
\text { compliance to be determined by meeting prescriptive } \\
\text { insulation requirements, by using U-factor alternatives, } \\
\text { or by using a total UA alternative. These sections also } \\
\text { provide guidance and exceptions that may be used. } \\
\text { However, note that the U-factor for steel-frame } \\
\text { envelope assemblies addressed in Section N1102.2.4 } \\
\text { shall be calculated using the ASHRAE zone method, or } \\
\text { a method providing equivalent results, and not a series- } \\
\text { parallel path calculation method as is stated in the code. } \\
\text { Additionally, Section N1102.2.2, which allows for the } \\
\text { reduction of ceiling insulation in space constrained } \\
\text { roof/ceiling assemblies, shall be limited to } 500 \text { sq. ft. or } \\
20 \% \text { of ceiling area, whichever is less. In all cases, } \\
\text { insulation shall be inspected to Grade } 1 \text { installation as } \\
\text { defined in the RESNET Standards by a RESNET- } \\
\text { certified rater. }\end{array}$ & $\begin{array}{l}\text { Prescriptive Path - ENERGY STAR V2 only meets a } \\
\text { portion of the IECC } 2009 \text { requirement. }\end{array}$ \\
\hline Prescriptive & $\begin{array}{l}\text { 402.2 Specific } \\
\text { insulation } \\
\text { requirements. } \\
\text { 402.2.1 Ceilings } \\
\text { with attic spaces. }\end{array}$ & $\begin{array}{l}\text { When Section } 402.1 .1 \text { would require R-38 } \\
\text { in the ceiling, R-30 shall be deemed to } \\
\text { satisfy the requirement for R- } 38 \text { whenever } \\
\text { the full height of uncompressed R-30 } \\
\text { insulation extends over the wall top plate } \\
\text { at the eaves. Similarly, R-38 shall be }\end{array}$ & $\begin{array}{l}\text { (Mandatory) Thermal Bypass Inspection Checklist } \\
\text { 5.0 Attic/ Ceiling Interface. All attic penetrations and } \\
\text { dropped ceilings include a full interior air barrier } \\
\text { aligned with insulation with any gaps fully sealed with } \\
\text { caulk, foam or tape. Movable insulation fits snugly in } \\
\text { opening and air barrier is fully gasketed. }\end{array}$ & $\begin{array}{l}\text { Mandatory and Prescriptive ENERGY STAR V2 } \\
\text { requirements meet the } 2009 \text { IECC requirement. }\end{array}$ \\
\hline
\end{tabular}




\begin{tabular}{|c|c|c|c|c|}
\hline $\begin{array}{l}\text { Requirement } \\
\text { Category }\end{array}$ & $\begin{array}{c}\text { IECC } \\
\text { Requirement } \\
\text { Reference }\end{array}$ & IECC & ES2 & Comments \\
\hline & & $\begin{array}{l}\text { deemed to satisfy the requirements for R- } \\
49 \text { where ever the full height of } \\
\text { uncompressed R-38 insulation extends } \\
\text { over the top plate at the eaves. This } \\
\text { reduction shall not apply to the U-factor } \\
\text { alternative approach in Section } 402.1 .3 \\
\text { and the total UA alternative in Section } \\
\text { 402.1.4. }\end{array}$ & $\begin{array}{l}\text { Prescriptive Path: Insulation levels of a home must } \\
\text { meet or exceed Sections N1102.1 and N1102.2 of the } \\
2004 \text { IRC. }\end{array}$ & \\
\hline Prescriptive & $\begin{array}{l}402.2 \text { Specific } \\
\text { insulation } \\
\text { requirements. } \\
402.2 .2 \text { Ceilings } \\
\text { without attic } \\
\text { spaces. }\end{array}$ & $\begin{array}{l}\text { Where Section } 402.1 .1 \text { would require } \\
\text { insulation levels above R- } 30 \text { and the } \\
\text { design often roof/ceiling assemble does } \\
\text { not allow sufficient space for the required } \\
\text { insulation, the minimum required } \\
\text { insulation for such roof/ceiling assemblies } \\
\text { shall be R-30. This reduction of insulation } \\
\text { from the requirements of Section } 402.1 .1 \\
\text { shall be limited to } 500 \text { square feet of } 20 \\
\text { percent of the total insulated ceiling area, } \\
\text { whichever is less. This reduction shall not } \\
\text { apply to the U-factor alternative approach } \\
\text { in Section } 402.1 .3 \text { and the total UA } \\
\text { alternative in Section } 4-2.1 .4 \text {. }\end{array}$ & $\begin{array}{l}\text { Prescriptive Path: The building thermal envelope must } \\
\text { meet the following requirements. Infiltration (ACH50): } \\
7 \text { in CZ's 1-2, } 6 \text { in CZ's 3-4, } 5 \text { in CZ's 5-7, and } 4 \text { in CZ } \\
\text { 8. And insulation levels must meet or exceed the } 2004 \\
\text { IRC, and a completed Thermal Bypass Inspection } \\
\text { checklist must be performed. Envelope leakage must be } \\
\text { determined by a RESNET- certified rater using a } \\
\text { RESNET- approved testing protocol. Insulation levels } \\
\text { of a home must meet or exceed Sections N1102.1 and } \\
\text { N1102.2 of the } 2004 \text { IRC. These sections allow for } \\
\text { compliance to be determined by meeting prescriptive } \\
\text { insulation requirements, by using U-factor alternatives, } \\
\text { or by using a total UA alternative. These sections also } \\
\text { provide guidance and exceptions that may be used. } \\
\text { However, note that the U-factor for steel-frame } \\
\text { envelope assemblies addressed in Section N1102.2.4 } \\
\text { shall be calculated using the ASHRAE zone method, or } \\
\text { a method providing equivalent results, and not a series- } \\
\text { parallel path calculation method as is stated in the code. } \\
\text { Additionally, Section N1102.2.2, which allows for the } \\
\text { reduction of ceiling insulation in space constrained } \\
\text { roof/ceiling assemblies, shall be limited to } 500 \text { sq. ft. or } \\
20 \% \text { of ceiling area, whichever is less. In all cases, } \\
\text { insulation shall be inspected to Grade } 1 \text { installation as } \\
\text { defined in the RESNET Standards by a RESNET- } \\
\text { certified rater. }\end{array}$ & $\begin{array}{l}\text { Prescriptive - ENERGY STAR V2 requirement } \\
\text { meets the } 2009 \text { IECC requirement. }\end{array}$ \\
\hline Prescriptive & $\begin{array}{l}\text { 402.2 Specific } \\
\text { insulation } \\
\text { requirements. } \\
\text { 402.2.3 Access } \\
\text { hatches and } \\
\text { doors. }\end{array}$ & $\begin{array}{l}\text { Access doors from conditioned spaces to } \\
\text { unconditioned spaces (e.g., attics and } \\
\text { crawl spaces) shall be weatherstripped and } \\
\text { insulated to a level equivalent to the } \\
\text { insulation on the surrounding surfaces. } \\
\text { Access shall be provided to all equipment } \\
\text { that prevents damaging or compressing the } \\
\text { insulation. A wood framed or equivalent } \\
\text { baffle or retainer is required to be provided } \\
\text { when loose fill insulation is installed, the } \\
\text { purpose of which is to prevent the loose } \\
\text { fill insulation from spilling into the living }\end{array}$ & $\begin{array}{l}\text { (Mandatory) Thermal Bypass Inspection Checklist } \\
\text { 1.0 Overall Air Barrier and Thermal Barrier Alignment. } \\
\text { Insulation shall be installed in full contact with sealed } \\
\text { interior and exterior air barrier except for alternate to } \\
\text { interior air barrier under item no. } 2 \text { (Walls Adjoining } \\
\text { Exterior Walls or Unconditioned Spaced). } \\
\text { 5.0 Attic/ Ceiling Interface. All attic penetrations and } \\
\text { dropped ceilings include a full interior air barrier } \\
\text { aligned with insulation with any gaps fully sealed with } \\
\text { caulk, foam or tape. Movable insulation fits snugly in } \\
\text { opening and air barrier is fully gasketed. }\end{array}$ & $\begin{array}{l}\text { Mandatory- ENERGY STAR V2 requirement meets } \\
\text { the } 2009 \text { IECC requirement. }\end{array}$ \\
\hline
\end{tabular}




\begin{tabular}{|c|c|c|c|c|}
\hline $\begin{array}{l}\text { Requirement } \\
\text { Category }\end{array}$ & $\begin{array}{c}\text { IECC } \\
\text { Requirement } \\
\text { Reference }\end{array}$ & IECC & ES2 & Comments \\
\hline & & $\begin{array}{l}\text { space when the attic access is opened, and } \\
\text { to provide a permanent means of } \\
\text { maintaining the installed R-value of the } \\
\text { loose fill insulation. }\end{array}$ & & \\
\hline Prescriptive & $\begin{array}{l}402.2 \text { Specific } \\
\text { insulation } \\
\text { requirements. } \\
\text { 402.2.4 Mass } \\
\text { walls. }\end{array}$ & $\begin{array}{l}\text { Mass walls for the purposes of this chapter } \\
\text { shall be considered above-grade walls of } \\
\text { concrete block, concrete, insulated } \\
\text { concrete form (ICF), masonry cavity, brick } \\
\text { (other than brick veneer), earth (adobe, } \\
\text { compressed earth block, rammed earth) } \\
\text { and solid timber/logs. }\end{array}$ & $\begin{array}{l}\text { (Mandatory) Thermal Bypass Inspection Checklist } \\
\text { Prescriptive Path: The building thermal envelope must } \\
\text { meet the following requirements. Infiltration (ACH50): } \\
7 \text { in CZ's 1-2, } 6 \text { in CZ's 3-4, } 5 \text { in CZ's 5-7, and } 4 \text { in CZ } \\
\text { 8. And insulation levels must meet or exceed the } 2004 \\
\text { IRC, and a completed Thermal Bypass Inspection } \\
\text { checklist must be performed. Envelope leakage must be } \\
\text { determined by a RESNET- certified rater using a } \\
\text { RESNET- approved testing protocol. Insulation levels } \\
\text { of a home must meet or exceed Sections N1102.1 and } \\
\text { N1102.2 of the } 2004 \text { IRC. These sections allow for } \\
\text { compliance to be determined by meeting prescriptive } \\
\text { insulation requirements, by using U-factor alternatives, } \\
\text { or by using a total UA alternative. These sections also } \\
\text { provide guidance and exceptions that may be used. } \\
\text { However, note that the U-factor for steel-frame } \\
\text { envelope assemblies addressed in Section N1102.2.4 } \\
\text { shall be calculated using the ASHRAE zone method, or } \\
\text { a method providing equivalent results, and not a series- } \\
\text { parallel path calculation method as is stated in the code. } \\
\text { Additionally, Section N1102.2.2, which allows for the } \\
\text { reduction of ceiling insulation in space constrained } \\
\text { roof/ceiling assemblies, shall be limited to } 500 \text { sq. ft. or } \\
\text { 20\% of ceiling area, whichever is less. In all cases, } \\
\text { insulation shall be inspected to Grade } 1 \text { installation as } \\
\text { defined in the RESNET Standards by a RESNET- } \\
\text { certified rater. }\end{array}$ & $\begin{array}{l}\text { Mandatory- ENERGY STAR V2 requirement meets } \\
\text { the } 2009 \text { IECC requirement. }\end{array}$ \\
\hline Prescriptive & $\begin{array}{l}\text { 402.2 Specific } \\
\text { insulation } \\
\text { requirements. } \\
\text { 402.2.5 Steel- } \\
\text { frame ceilings, } \\
\text { walls, and floors. }\end{array}$ & $\begin{array}{l}\text { Steel-frame ceilings, walls and floors shall } \\
\text { meet the insulation requirements of Table } \\
402.2 .5 \text { or shall meet the U-factor } \\
\text { requirements in Table } 402.1 .3 \text {. The } \\
\text { calculation of the U-factor for a steel- } \\
\text { frame envelope assembly shall use a } \\
\text { series-parallel path calculation method. } \\
\text { Exception: In Climate Zones } 1 \text { and } 2 \text {, the } \\
\text { continuous insulation requirements in } \\
\text { Table } 402.2 .5 \text { shall be permitted to be } \\
\text { reduced to R-3 for steel frame wall } \\
\text { assemblies with studs spaced at } 24 \text { inches } \\
\text { ( } 610 \text { mm) on center. }\end{array}$ & $\begin{array}{l}\text { Prescriptive Path: The building thermal envelope must } \\
\text { meet the following requirements. Infiltration (ACH50): } \\
7 \text { in CZ's 1-2, } 6 \text { in CZ's 3-4, } 5 \text { in CZ's 5-7, and } 4 \text { in CZ } \\
\text { 8. And insulation levels must meet or exceed the } 2004 \\
\text { IRC, and a completed Thermal Bypass Inspection } \\
\text { checklist must be performed. Envelope leakage must be } \\
\text { determined by a RESNET- certified rater using a } \\
\text { RESNET- approved testing protocol. Insulation levels } \\
\text { of a home must meet or exceed Sections N1102.1 and } \\
\text { N1102.2 of the } 2004 \text { IRC. These sections allow for } \\
\text { compliance to be determined by meeting prescriptive } \\
\text { insulation requirements, by using U-factor alternatives, } \\
\text { or by using a total UA alternative. These sections also } \\
\text { provide guidance and exceptions that may be used. } \\
\text { However, note that the U-factor for steel-frame }\end{array}$ & $\begin{array}{l}\text { Unclear if steel framed calculation process } \\
\text { referenced in ENERGY STAR V2 is more or less } \\
\text { stringent than what is in the } 2009 \text { IECC. Different } \\
\text { methods are used for the calculations. }\end{array}$ \\
\hline
\end{tabular}




\begin{tabular}{|c|c|c|c|c|}
\hline $\begin{array}{l}\text { Requirement } \\
\text { Category }\end{array}$ & $\begin{array}{c}\text { IECC } \\
\text { Requirement } \\
\text { Reference }\end{array}$ & IECC & ES2 & Comments \\
\hline & & & $\begin{array}{l}\text { envelope assemblies addressed in Section N1102.2.4 } \\
\text { shall be calculated using the ASHRAE zone method, or } \\
\text { a method providing equivalent results, and not a series- } \\
\text { parallel path calculation method as is stated in the code. } \\
\text { Additionally, Section N1102.2.2, which allows for the } \\
\text { reduction of ceiling insulation in space constrained } \\
\text { roof/ceiling assemblies, shall be limited to } 500 \text { sq. ft. or } \\
20 \% \text { of ceiling area, whichever is less. In all cases, } \\
\text { insulation shall be inspected to Grade } 1 \text { installation as } \\
\text { defined in the RESNET Standards by a RESNET- } \\
\text { certified rater. }\end{array}$ & \\
\hline Prescriptive & $\begin{array}{l}402.2 \text { Specific } \\
\text { insulation } \\
\text { requirements. } \\
\text { 402.2.6 Floors. }\end{array}$ & $\begin{array}{l}\text { Floor insulation shall be installed to } \\
\text { maintain permanent contact with the } \\
\text { underside of the subfloor decking. }\end{array}$ & $\begin{array}{l}\text { (Mandatory) Thermal Bypass Inspection Checklist } \\
\text { 1.0 Overall Air Barrier and Thermal Barrier Alignment. } \\
\text { Insulation shall be installed in full contact with sealed } \\
\text { interior and exterior air barrier except for alternate to } \\
\text { interior air barrier under item no. } 2 \text { (Walls Adjoining } \\
\text { Exterior Walls or Unconditioned Spaced). } \\
\text { 3.0 Floors between Conditioned and Exterior Spaces. } \\
\text { Air barrier is installed at any exposed fibrous insulation } \\
\text { edges. Insulation is installed to maintain permanent } \\
\text { contact with sub-floor above including necessary } \\
\text { supports (e.g., staves for blankets, netting for blown-in). } \\
\text { Blanket insulation is verified to have no gaps, voids or } \\
\text { compressions. Blown-in insulation is verified to have } \\
\text { proper density with firm packing. }\end{array}$ & $\begin{array}{l}\text { Mandatory- ENERGY STAR V2 requirement meets } \\
\text { the } 2009 \text { IECC requirement. }\end{array}$ \\
\hline Prescriptive & $\begin{array}{l}402.2 \text { Specific } \\
\text { insulation } \\
\text { requirements. } \\
\text { 402.2.7 Basement } \\
\text { walls. }\end{array}$ & $\begin{array}{l}\text { Walls associated with conditioned } \\
\text { basements shall be insulated from the top } \\
\text { of the basement wall down to } 10 \text { feet } \\
(3048 \mathrm{~mm}) \text { below grade or to the basement } \\
\text { floor, whichever is less. Walls associated } \\
\text { with unconditioned basements shall meet } \\
\text { this requirement unless the floor overhead } \\
\text { is insulated in accordance with Sections } \\
402.1 .1 \text { and } 402.2 .6 \text {. }\end{array}$ & $\begin{array}{l}\text { Prescriptive Path: The building thermal envelope must } \\
\text { meet the following requirements. Infiltration (ACH50): } \\
7 \text { in CZ's } 1-2,6 \text { in CZ's } 3-4,5 \text { in CZ's 5-7, and } 4 \text { in CZ } \\
\text { 8. And insulation levels must meet or exceed the } 2004 \\
\text { IRC, and a completed Thermal Bypass Inspection } \\
\text { checklist must be performed. Envelope leakage must be } \\
\text { determined by a RESNET- certified rater using a } \\
\text { RESNET- approved testing protocol. Insulation levels } \\
\text { of a home must meet or exceed Sections N1102.1 and } \\
\text { N1102.2 of the } 2004 \text { IRC. These sections allow for } \\
\text { compliance to be determined by meeting prescriptive } \\
\text { insulation requirements, by using U-factor alternatives, } \\
\text { or by using a total UA alternative. These sections also } \\
\text { provide guidance and exceptions that may be used. } \\
\text { However, note that the U-factor for steel-frame } \\
\text { envelope assemblies addressed in Section N1102.2.4 } \\
\text { shall be calculated using the ASHRAE zone method, or } \\
\text { a method providing equivalent results, and not a series- } \\
\text { parallel path calculation method as is stated in the code. } \\
\text { Additionally, Section N1102.2.2, which allows for the } \\
\text { reduction of ceiling insulation in space constrained }\end{array}$ & $\begin{array}{l}\text { Prescriptive - ENERGY STAR V2 requirement } \\
\text { meets the } 2009 \text { IECC requirement. }\end{array}$ \\
\hline
\end{tabular}




\begin{tabular}{|c|c|c|c|c|}
\hline $\begin{array}{l}\text { Requirement } \\
\text { Category }\end{array}$ & $\begin{array}{c}\text { IECC } \\
\text { Requirement } \\
\text { Reference }\end{array}$ & IECC & ES2 & Comments \\
\hline & & & $\begin{array}{l}\text { roof/ceiling assemblies, shall be limited to } 500 \text { sq. ft. or } \\
20 \% \text { of ceiling area, whichever is less. In all cases, } \\
\text { insulation shall be inspected to Grade } 1 \text { installation as } \\
\text { defined in the RESNET Standards by a RESNET- } \\
\text { certified rater. }\end{array}$ & \\
\hline Prescriptive & $\begin{array}{l}\text { 402.2 Specific } \\
\text { insulation } \\
\text { requirements. } \\
\text { 402.2.8 Slab-on- } \\
\text { grade floors. }\end{array}$ & $\begin{array}{l}\text { Slab-on-grade floors with a floor surface } \\
\text { less than } 12 \text { inches ( } 305 \text { mm) below grade } \\
\text { shall be insulated in accordance with Table } \\
402.1 .1 \text {. The insulation shall extend } \\
\text { downward from the top of the slab on the } \\
\text { outside or inside of the foundation wall. } \\
\text { Insulation located below grade shall be } \\
\text { extended the distance provided in Table } \\
402.1 .1 \text { by any combination of vertical } \\
\text { insulation, insulation extending under the } \\
\text { slab or insulation extending out from the } \\
\text { building. Insulation extending away from } \\
\text { the building shall be protected by } \\
\text { pavement or by a minimum of } 10 \text { inches } \\
\text { ( } 254 \text { mm) of soil. The top edge of the } \\
\text { insulation installed between the exterior } \\
\text { wall and the edge of the interior slab shall } \\
\text { be permitted to be cut at a } 45 \text {-degree (0.79 } \\
\text { rad) angle away from the exterior wall. } \\
\text { Slab-edge insulation is not required in } \\
\text { jurisdictions designated by the code } \\
\text { official as having a very heavy termite } \\
\text { infestation. }\end{array}$ & $\begin{array}{l}\text { (Mandatory) Thermal Bypass Inspection Checklist } \\
1.0 \text { Overall Air Barrier and Thermal Barrier Alignment. } \\
\text { Insulation shall be installed in full contact with sealed } \\
\text { interior and exterior air barrier except for alternate to } \\
\text { interior air barrier under item no. } 2 \text { (Walls Adjoining } \\
\text { Exterior Walls or Unconditioned Spaced). Only at } \\
\text { Climate Zones } 4 \text { and Higher: 1.4- Slab-edge insulation } \\
\text { (A maximum of 25\% of the slab edge may be } \\
\text { uninsulated in Climate Zones } 4 \text { and 5). } \\
\text { Prescriptive Path: The building thermal envelope must } \\
\text { meet the following requirements. Infiltration (ACH50): } \\
7 \text { in CZ's 1-2, } 6 \text { in CZ's 3-4, } 5 \text { in CZ's 5-7, and } 4 \text { in CZ } \\
\text { 8. And insulation levels must meet or exceed the 2004 } \\
\text { IRC, and a completed Thermal Bypass Inspection } \\
\text { checklist must be performed. Envelope leakage must be } \\
\text { determined by a RESNET- certified rater using a } \\
\text { RESNET- approved testing protocol. Insulation levels } \\
\text { of a home must meet or exceed Sections N1102.1 and } \\
\text { N1102.2 of the } 2004 \text { IRC. These sections allow for } \\
\text { compliance to be determined by meeting prescriptive } \\
\text { insulation requirements, by using U-factor alternatives, } \\
\text { or by using a total UA alternative. These sections also } \\
\text { provide guidance and exceptions that may be used. } \\
\text { However, note that the U-factor for steel-frame } \\
\text { envelope assemblies addressed in Section N1102.2.4 } \\
\text { shall be calculated using the ASHRAE zone method, or } \\
\text { a method providing equivalent results, and not a series- } \\
\text { parallel path calculation method as is stated in the code. } \\
\text { Additionally, Section N1102.2.2, which allows for the } \\
\text { reduction of ceiling insulation in space constrained } \\
\text { roof/ceiling assemblies, shall be limited to 500 sq. ft. or } \\
20 \% \text { of ceiling area, whichever is less. In all cases, } \\
\text { insulation shall be inspected to Grade } 1 \text { installation as } \\
\text { defined in the RESNET Standards by a RESNET- } \\
\text { certified rater. }\end{array}$ & $\begin{array}{l}\text { Mandatory and Prescriptive ENERGY STAR V2 } \\
\text { requirements meet the } 2009 \text { IECC requirement. }\end{array}$ \\
\hline Prescriptive & $\begin{array}{l}\text { 402.2 Specific } \\
\text { insulation } \\
\text { requirements. } \\
\text { 402.2.9 Crawl } \\
\text { space walls. }\end{array}$ & $\begin{array}{l}\text { As an alternative to insulating floors over } \\
\text { crawl spaces, crawl space walls shall be } \\
\text { permitted to be insulated when the crawl } \\
\text { space is not vented to the outside. Crawl } \\
\text { space wall insulation shall be permanently } \\
\text { fastened to the wall and extend downward }\end{array}$ & $\begin{array}{l}\text { Prescriptive Path: The building thermal envelope must } \\
\text { meet the following requirements. Infiltration (ACH50): } \\
7 \text { in CZ's 1-2, } 6 \text { in CZ's 3-4, } 5 \text { in CZ's 5-7, and } 4 \text { in CZ } \\
\text { 8. And insulation levels must meet or exceed the } 2004 \\
\text { IRC, and a completed Thermal Bypass Inspection } \\
\text { checklist must be performed. Envelope leakage must be }\end{array}$ & $\begin{array}{l}\text { Prescriptive Path: Energy Star V2 requirements } \\
\text { meet the } 2009 \text { IECC }\end{array}$ \\
\hline
\end{tabular}




\begin{tabular}{|c|c|c|c|c|}
\hline $\begin{array}{l}\text { Requirement } \\
\text { Category }\end{array}$ & $\begin{array}{c}\text { IECC } \\
\text { Requirement } \\
\text { Reference } \\
\end{array}$ & IECC & ES2 & Comments \\
\hline & & $\begin{array}{l}\text { from the floor to the finished grade level } \\
\text { and then vertically and/or horizontally for } \\
\text { at least an additional } 24 \text { inches ( } 610 \mathrm{~mm}) \text {. } \\
\text { Exposed earth in unvented crawl space } \\
\text { foundations shall be covered with a } \\
\text { continuous Class I vapor retarder in } \\
\text { accordance with the International Building } \\
\text { Code. All joints of the vapor retarder shall } \\
\text { overlap by } 6 \text { inches ( } 153 \mathrm{~mm} \text { ) and be } \\
\text { sealed or taped. The edges of the vapor } \\
\text { retarder shall extend at least } 6 \text { inches ( } 153 \\
\text { mm) up the stem wall and shall be } \\
\text { attached to the stem wall. }\end{array}$ & $\begin{array}{l}\text { determined by a RESNET- certified rater using a } \\
\text { RESNET- approved testing protocol. Insulation levels } \\
\text { of a home must meet or exceed Sections N1102.1 and } \\
\text { N1102.2 of the } 2004 \text { IRC. These sections allow for } \\
\text { compliance to be determined by meeting prescriptive } \\
\text { insulation requirements, by using U-factor alternatives, } \\
\text { or by using a total UA alternative. These sections also } \\
\text { provide guidance and exceptions that may be used. } \\
\text { However, note that the U-factor for steel-frame } \\
\text { envelope assemblies addressed in Section N1102.2.4 } \\
\text { shall be calculated using the ASHRAE zone method, or } \\
\text { a method providing equivalent results, and not a series- } \\
\text { parallel path calculation method as is stated in the code. } \\
\text { Additionally, Section N1102.2.2, which allows for the } \\
\text { reduction of ceiling insulation in space constrained } \\
\text { roof/ceiling assemblies, shall be limited to } 500 \text { sq. ft. or } \\
20 \% \text { of ceiling area, whichever is less. In all cases, } \\
\text { insulation shall be inspected to Grade } 1 \text { installation as } \\
\text { defined in the RESNET Standards by a RESNET- } \\
\text { certified rater. }\end{array}$ & \\
\hline Prescriptive & $\begin{array}{l}\text { 402.2 Specific } \\
\text { insulation } \\
\text { requirements. } \\
402.2 .10 \\
\text { Masonry veneer. }\end{array}$ & $\begin{array}{l}\text { Insulation shall not be required on the } \\
\text { horizontal portion of the foundation that } \\
\text { supports a masonry veneer. }\end{array}$ & $\begin{array}{l}\text { Prescriptive Path: The building thermal envelope must } \\
\text { meet the following requirements. Infiltration (ACH50): } \\
7 \text { in CZ's 1-2, } 6 \text { in CZ's 3-4, } 5 \text { in CZ's 5-7, and } 4 \text { in CZ } \\
\text { 8. And insulation levels must meet or exceed the } 2004 \\
\text { IRC, and a completed Thermal Bypass Inspection } \\
\text { checklist must be performed. Envelope leakage must be } \\
\text { determined by a RESNET- certified rater using a } \\
\text { RESNET- approved testing protocol. Insulation levels } \\
\text { of a home must meet or exceed Sections N1102.1 and } \\
\text { N1102.2 of the } 2004 \text { IRC. These sections allow for } \\
\text { compliance to be determined by meeting prescriptive } \\
\text { insulation requirements, by using U-factor alternatives, } \\
\text { or by using a total UA alternative. These sections also } \\
\text { provide guidance and exceptions that may be used. } \\
\text { However, note that the U-factor for steel-frame } \\
\text { envelope assemblies addressed in Section N1102.2.4 } \\
\text { shall be calculated using the ASHRAE zone method, or } \\
\text { a method providing equivalent results, and not a series- } \\
\text { parallel path calculation method as is stated in the code. } \\
\text { Additionally, Section N1102.2.2, which allows for the } \\
\text { reduction of ceiling insulation in space constrained } \\
\text { roof/ceiling assemblies, shall be limited to } 500 \text { sq. ft. or } \\
\text { 20\% of ceiling area, whichever is less. In all cases, } \\
\text { insulation shall be inspected to Grade } 1 \text { installation as } \\
\text { defined in the RESNET Standards by a RESNET- } \\
\text { certified rater. }\end{array}$ & $\begin{array}{l}\text { Prescriptive - ENERGY STAR V2 requirement } \\
\text { meets the } 2009 \text { IECC requirement. }\end{array}$ \\
\hline
\end{tabular}




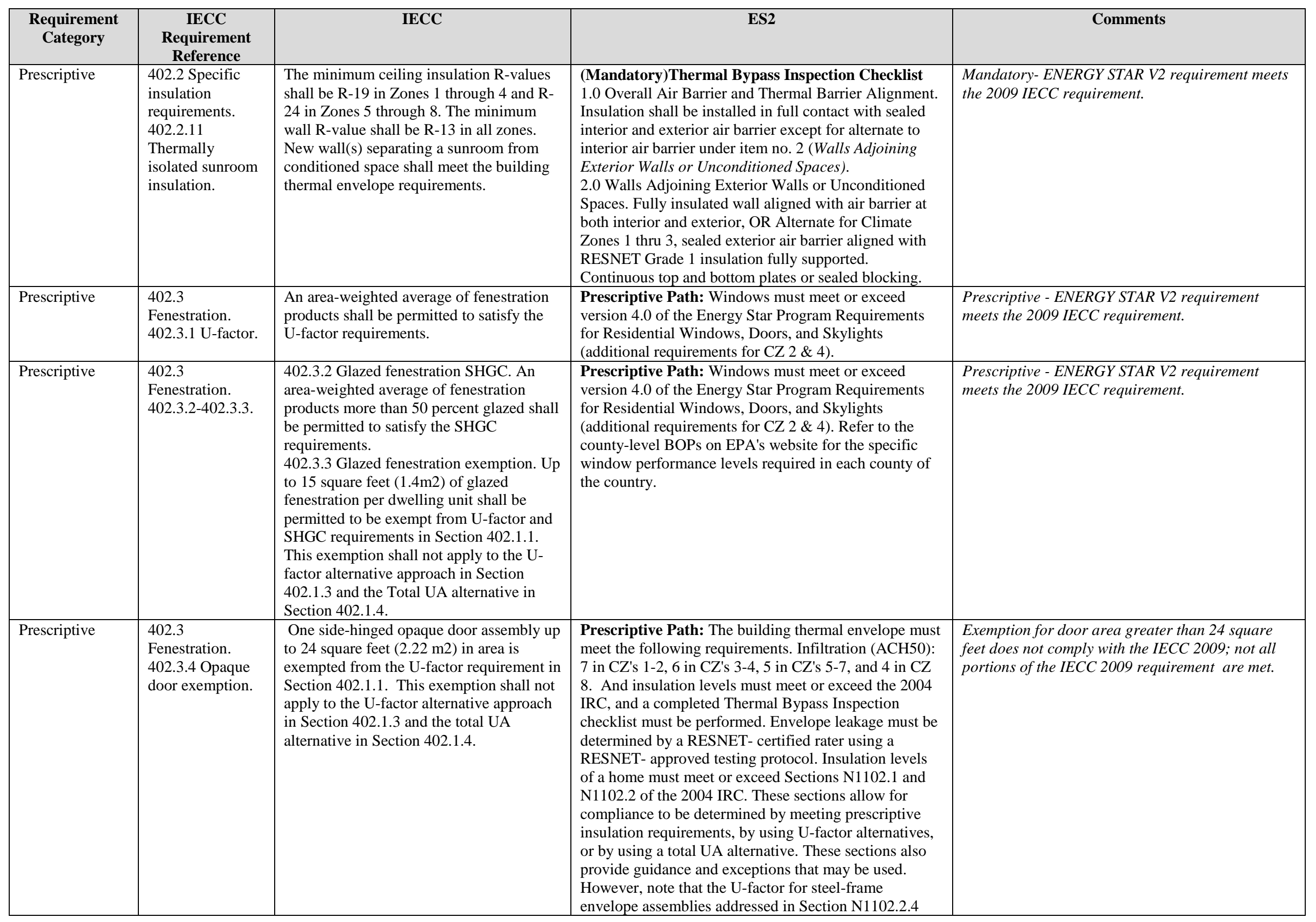




\begin{tabular}{|c|c|c|c|c|}
\hline $\begin{array}{c}\text { Requirement } \\
\text { Category }\end{array}$ & $\begin{array}{c}\text { IECC } \\
\text { Requirement } \\
\text { Reference }\end{array}$ & IECC & ES2 & Comments \\
\hline & & & $\begin{array}{l}\text { shall be calculated using the ASHRAE zone method, or } \\
\text { a method providing equivalent results, and not a series- } \\
\text { parallel path calculation method as is stated in the code. } \\
\text { Additionally, Section N1102.2.2, which allows for the } \\
\text { reduction of ceiling insulation in space constrained } \\
\text { roof/ceiling assemblies, shall be limited to } 500 \text { sq. ft. or } \\
20 \% \text { of ceiling area, whichever is less. In all cases, } \\
\text { insulation shall be inspected to Grade } 1 \text { installation as } \\
\text { defined in the RESNET Standards by a RESNET- } \\
\text { certified rater. }\end{array}$ & \\
\hline & $\begin{array}{l}402.3 \\
\text { Fenestration. } \\
402.3 .5 \\
\text { Thermally } \\
\text { isolated sunroom } \\
\text { U-factor. }\end{array}$ & $\begin{array}{l}\text { For Zones } 4 \text { through } 8 \text {, the maximum } \\
\text { fenestration U-factor shall be } 0.50 \text { and the } \\
\text { maximum skylight U-factor shall be } 0.75 \text {. } \\
\text { New windows and doors separating the } \\
\text { sunroom from conditioned space shall } \\
\text { meet the building thermal envelope } \\
\text { requirements. }\end{array}$ & - & Not explicitly mentioned in ENERGY STAR V2. \\
\hline & $\begin{array}{l}402.3 \\
\text { Fenestration. } \\
402.3 .6 \\
\text { Replacement } \\
\text { fenestration. }\end{array}$ & $\begin{array}{l}\text { Where some or all of an existing } \\
\text { fenestration unit is replaced with a new } \\
\text { fenestration product, including sash and } \\
\text { glazing, the replacement fenestration unit } \\
\text { shall meet the applicable requirements for } \\
\text { U-factor and SHGC in Table 402.1.1. }\end{array}$ & - & Not explicitly mentioned in ENERGY STAR V2. \\
\hline Mandatory & $\begin{array}{l}\text { 402.4 Air } \\
\text { leakage. } \\
\text { 402.4.1 Building } \\
\text { thermal envelope. }\end{array}$ & $\begin{array}{l}\text { The building thermal envelope shall be } \\
\text { durably sealed to limit infiltration. The } \\
\text { sealing methods between dissimilar } \\
\text { materials shall allow for differential } \\
\text { expansion and contraction. The following } \\
\text { shall be caulked, gasketed, } \\
\text { weatherstripped or otherwise sealed with } \\
\text { an air barrier material, suitable film or } \\
\text { solid material: }\end{array}$ & 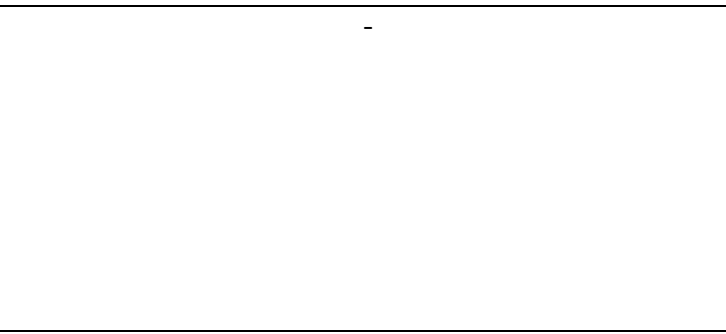 & General guidance - not a unique requirement. \\
\hline Mandatory & $\begin{array}{l}\text { 402.4 Air } \\
\text { leakage. } \\
\text { 402.4.1 Building } \\
\text { thermal envelope. } \\
\text { (1) }\end{array}$ & $\begin{array}{l}\text { The following shall be caulked, gasketed, } \\
\text { weatherstripped or otherwise sealed with } \\
\text { an air barrier material, suitable film or } \\
\text { solid material: } \\
\text { 1. All joints, seams and penetrations. }\end{array}$ & $\begin{array}{l}\text { (Mandatory) Thermal Bypass Inspection Checklist } \\
1.0 \text { Overall Air Barrier And Thermal Barrier Alignment. } \\
\text { Insulation shall be installed in full contact with sealed } \\
\text { interior and exterior air barrier except for alternate to } \\
\text { interior air barrier under item no. } 2 \text { (Walls Adjoining } \\
\text { Exterior Walls or Unconditioned Spaces). } \\
\text { 2.0 Walls Adjoining Exterior Walls or Unconditioned } \\
\text { Spaces. Fully insulated wall aligned with air barrier at } \\
\text { both interior and exterior, OR, alternate for climate } \\
\text { zones } 1 \text { thru 3, sealed exterior air barrier aligned with } \\
\text { RESNET Grade } 1 \text { Insulation fully supported. } \\
\text { Continuous top and bottom plates or sealed blocking. } \\
\text { 3.0 Floors between Conditioned and Exterior Spaces. } \\
\text { Air barrier is installed at any exposed fibrous insulation }\end{array}$ & $\begin{array}{l}\text { Mandatory- ENERGY STAR V2 requirement } \\
\text { exceeds the } 2009 \text { IECC requirement. }\end{array}$ \\
\hline
\end{tabular}




\begin{tabular}{|c|c|c|c|c|}
\hline $\begin{array}{l}\text { Requirement } \\
\text { Category }\end{array}$ & $\begin{array}{c}\text { IECC } \\
\text { Requirement } \\
\text { Reference }\end{array}$ & IECC & ES2 & Comments \\
\hline & & & $\begin{array}{l}\text { edges. Insulation is installed to maintain permanent } \\
\text { contact with sub-floor above including necessary } \\
\text { supports (e.g., staves for blankets, netting for blown-in). } \\
\text { Blanket insulation is verified to have no gaps, voids or } \\
\text { compression. Blown-in insulation is verified to have } \\
\text { proper density with firm packing. } \\
\text { 4.0 Shafts. Openings to unconditioned space are fully } \\
\text { sealed with solid blocking or flashing and any } \\
\text { remaining gaps are sealed with caulk or foam (provide } \\
\text { fire-rated collars and caulking where required). } \\
5.0 \text { Attic/Ceiling Interface. All attic penetrations and } \\
\text { dropped ceilings include a fully interior air barrier } \\
\text { aligned with insulation with any gaps fully sealed with } \\
\text { caulk, foam or tape. Movable insulation fits snugly in } \\
\text { opening and air barrier is fully gasketed. }\end{array}$ & \\
\hline Mandatory & $\begin{array}{l}\text { 402.4 Air } \\
\text { leakage. } \\
\text { 402.4.1 Building } \\
\text { thermal envelope. } \\
\text { (2) }\end{array}$ & $\begin{array}{l}\text { The following shall be caulked, gasketed, } \\
\text { weatherstripped or otherwise sealed with } \\
\text { an air barrier material, suitable film or } \\
\text { solid material: } \\
\text { 2. Site-built windows, doors and skylights. }\end{array}$ & $\begin{array}{l}\text { (Mandatory) Thermal Bypass Inspection Checklist } \\
\text { 1.0 Overall Air Barrier And Thermal Barrier Alignment. } \\
\text { Insulation shall be installed in full contact with sealed } \\
\text { interior and exterior air barrier except for alternate to } \\
\text { interior air barrier under item no. } 2 \text { (Walls Adjoining } \\
\text { Exterior Walls or Unconditioned Spaces). }\end{array}$ & $\begin{array}{l}\text { Mandatory- ENERGY STAR V2 requirement } \\
\text { exceeds the } 2009 \text { IECC requirement. }\end{array}$ \\
\hline Mandatory & $\begin{array}{l}\text { 402.4 Air } \\
\text { leakage. } \\
\text { 402.4.1 Building } \\
\text { thermal envelope. } \\
\text { (3) }\end{array}$ & $\begin{array}{l}\text { The following shall be caulked, gasketed, } \\
\text { weatherstripped or otherwise sealed with } \\
\text { an air barrier material, suitable film or } \\
\text { solid material: } \\
\text { 3. Openings between window and door } \\
\text { assemblies and their respective jambs and } \\
\text { framing. }\end{array}$ & $\begin{array}{l}\text { (Mandatory) Thermal Bypass Inspection Checklist } \\
\text { 1.0 Overall Air Barrier And Thermal Barrier Alignment. } \\
\text { Insulation shall be installed in full contact with sealed } \\
\text { interior and exterior air barrier except for alternate to } \\
\text { interior air barrier under item no. } 2 \text { (Walls Adjoining } \\
\text { Exterior Walls or Unconditioned Spaces). } \\
\text { 2.0 Walls Adjoining Exterior Walls or Unconditioned } \\
\text { Spaces. Fully insulated wall aligned with air barrier at } \\
\text { both interior and exterior, OR, alternate for climate } \\
\text { zones } 1 \text { thru 3, sealed exterior air barrier aligned with } \\
\text { RESNET Grade } 1 \text { Insulation fully supported. } \\
\text { Continuous top and bottom plates or sealed blocking. } \\
\text { 3.0 Floors between Conditioned and Exterior Spaces. } \\
\text { Air barrier is installed at any exposed fibrous insulation } \\
\text { edges. Insulation is installed to maintain permanent } \\
\text { contact with sub-floor above including necessary } \\
\text { supports (e.g., staves for blankets, netting for blown-in). } \\
\text { Blanket insulation is verified to have no gaps, voids or } \\
\text { compression. Blown-in insulation is verified to have } \\
\text { proper density with firm packing. } \\
\text { 4.0 Shafts. Openings to unconditioned space are fully } \\
\text { sealed with solid blocking or flashing and any } \\
\text { remaining gaps are sealed with caulk or foam (provide } \\
\text { fire-rated collars and caulking where required). } \\
5.0 \text { Attic/Ceiling Interface. All attic penetrations and }\end{array}$ & $\begin{array}{l}\text { Mandatory- ENERGY STAR V2 requirement } \\
\text { exceeds the } 2009 \text { IECC requirement. }\end{array}$ \\
\hline
\end{tabular}




\begin{tabular}{|c|c|c|c|c|}
\hline $\begin{array}{l}\text { Requirement } \\
\text { Category }\end{array}$ & $\begin{array}{c}\text { IECC } \\
\text { Requirement } \\
\text { Reference }\end{array}$ & IECC & ES2 & Comments \\
\hline & & & $\begin{array}{l}\text { dropped ceilings include a fully interior air barrier } \\
\text { aligned with insulation with any gaps fully sealed with } \\
\text { caulk, foam or tape. Movable insulation fits snugly in } \\
\text { opening and air barrier is fully gasketed. }\end{array}$ & \\
\hline Mandatory & $\begin{array}{l}\text { 402.4 Air } \\
\text { leakage. } \\
\text { 402.4.1 Building } \\
\text { thermal envelope. } \\
\text { (4) }\end{array}$ & $\begin{array}{l}\text { The following shall be caulked, gasketed, } \\
\text { weatherstripped or otherwise sealed with } \\
\text { an air barrier material, suitable film or } \\
\text { solid material: } \\
\text { 4. Utility penetrations. }\end{array}$ & $\begin{array}{l}\text { (Mandatory) Thermal Bypass Inspection Checklist } \\
\text { 1.0 Overall Air Barrier And Thermal Barrier Alignment. } \\
\text { Insulation shall be installed in full contact with sealed } \\
\text { interior and exterior air barrier except for alternate to } \\
\text { interior air barrier under item no. } 2 \text { (Walls Adjoining } \\
\text { Exterior Walls or Unconditioned Spaces). } \\
\text { 2.0 Walls Adjoining Exterior Walls or Unconditioned } \\
\text { Spaces. Fully insulated wall aligned with air barrier at } \\
\text { both interior and exterior, OR, alternate for climate } \\
\text { zones } 1 \text { thru 3, sealed exterior air barrier aligned with } \\
\text { RESNET Grade } 1 \text { Insulation fully supported. } \\
\text { Continuous top and bottom plates or sealed blocking. } \\
\text { 3.0 Floors between Conditioned and Exterior Spaces. } \\
\text { Air barrier is installed at any exposed fibrous insulation } \\
\text { edges. Insulation is installed to maintain permanent } \\
\text { contact with sub-floor above including necessary } \\
\text { supports (e.g., staves for blankets, netting for blown-in). } \\
\text { Blanket insulation is verified to have no gaps, voids or } \\
\text { compression. Blown-in insulation is verified to have } \\
\text { proper density with firm packing. } \\
4.0 \text { Shafts. Openings to unconditioned space are fully } \\
\text { sealed with solid blocking or flashing and any } \\
\text { remaining gaps are sealed with caulk or foam (provide } \\
\text { fire-rated collars and caulking where required). } \\
\text { 5.0 Attic/Ceiling Interface. All attic penetrations and } \\
\text { dropped ceilings include a fully interior air barrier } \\
\text { aligned with insulation with any gaps fully sealed with } \\
\text { caulk, foam or tape. Movable insulation fits snugly in } \\
\text { opening and air barrier is fully gasketed. }\end{array}$ & $\begin{array}{l}\text { Mandatory- ENERGY STAR V2 requirement } \\
\text { exceeds the } 2009 \text { IECC requirement. }\end{array}$ \\
\hline \multirow[t]{2}{*}{ Mandatory } & $\begin{array}{l}\text { 402.4 Air } \\
\text { leakage. } \\
\text { 402.4.1 Building } \\
\text { thermal envelope. } \\
\text { (5) }\end{array}$ & $\begin{array}{l}\text { The following shall be caulked, gasketed, } \\
\text { weatherstripped or otherwise sealed with } \\
\text { an air barrier material, suitable film or } \\
\text { solid material: } \\
\text { 5. Dropped ceilings or chases adjacent to } \\
\text { the thermal envelope. }\end{array}$ & $\begin{array}{l}\text { (Mandatory) Thermal Bypass Inspection Checklist } \\
\text { 5.0 Attic/ Ceiling Interface. All attic penetrations and } \\
\text { dropped ceilings include a full interior air barrier } \\
\text { aligned with insulation with any gaps fully sealed with } \\
\text { caulk, foam or tape. Movable insulation fits snugly in } \\
\text { opening and air barrier is fully gasketed. }\end{array}$ & $\begin{array}{l}\text { Mandatory- ENERGY STAR V2 requirement } \\
\text { exceeds the } 2009 \text { IECC requirement. }\end{array}$ \\
\hline & $\begin{array}{l}\text { 402.4 Air } \\
\text { leakage. } \\
\text { 402.4.1 Building } \\
\text { thermal envelope. } \\
\text { (6) }\end{array}$ & $\begin{array}{l}\text { The following shall be caulked, gasketed, } \\
\text { weatherstripped or otherwise sealed with } \\
\text { an air barrier material, suitable film or } \\
\text { solid material: } \\
\text { 6. Knee walls. }\end{array}$ & $\begin{array}{l}\text { (Mandatory) Thermal Bypass Inspection Checklist } \\
2.0 \text { Walls Adjoining Exterior Walls or Unconditioned } \\
\text { Spaces. Fully insulated wall aligned with air barrier at } \\
\text { both interior and exterior, OR, alternate for climate } \\
\text { zones } 1 \text { thru 3, sealed exterior air barrier aligned with } \\
\text { RESNET Grade } 1 \text { insulation fully supported. } \\
\text { Continuous top and bottom plates or sealed blocking. }\end{array}$ & $\begin{array}{l}\text { Mandatory- ENERGY STAR V2 requirement } \\
\text { exceeds the } 2009 \text { IECC requirement. }\end{array}$ \\
\hline
\end{tabular}

D.12 


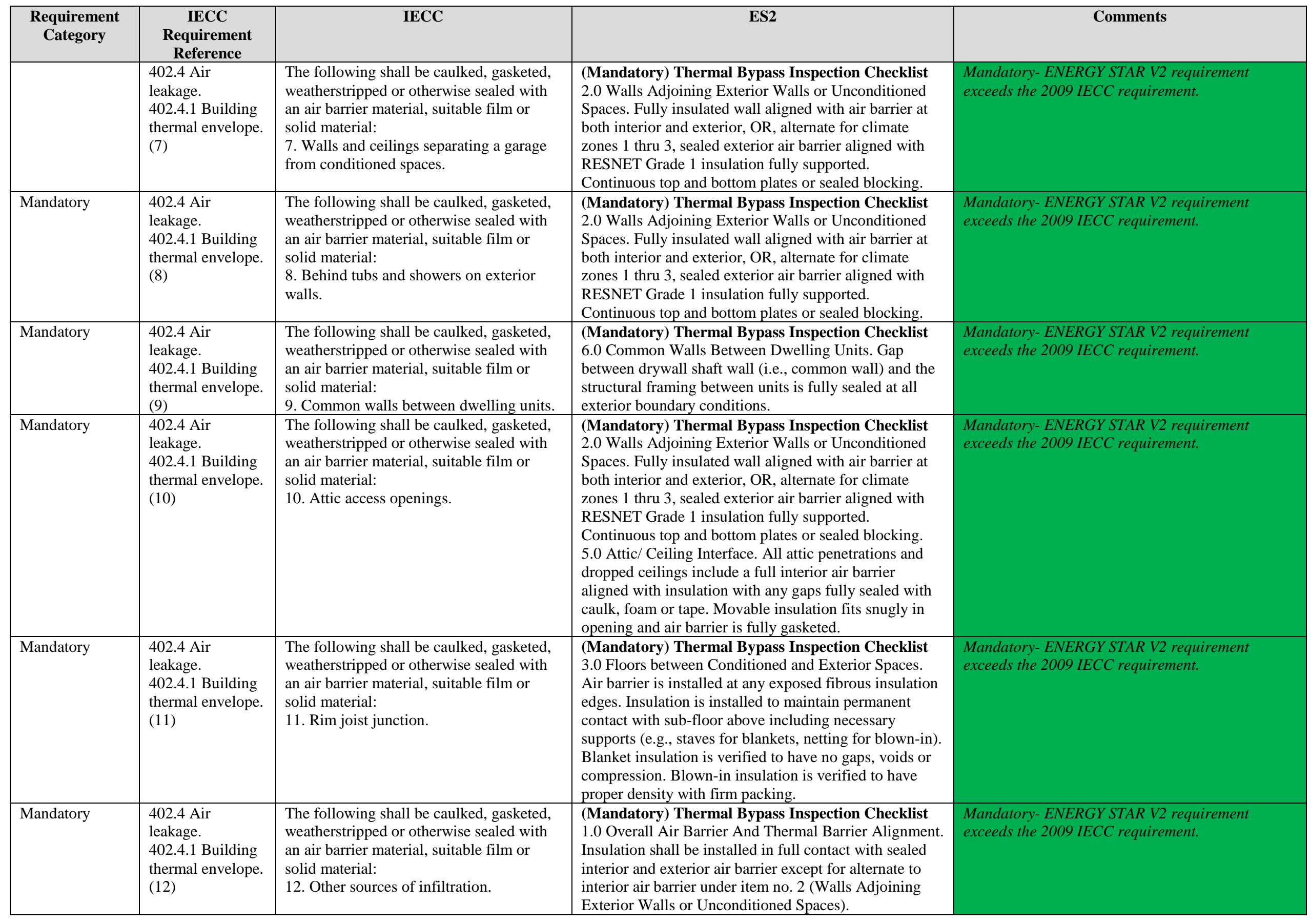




\begin{tabular}{|c|c|c|c|c|}
\hline $\begin{array}{l}\text { Requirement } \\
\text { Category }\end{array}$ & $\begin{array}{c}\text { IECC } \\
\text { Requirement } \\
\text { Reference } \\
\end{array}$ & IECC & ES2 & Comments \\
\hline & & & $\begin{array}{l}\text { 2.0 Walls Adjoining Exterior Walls or Unconditioned } \\
\text { Spaces. Fully insulated wall aligned with air barrier at } \\
\text { both interior and exterior, OR, alternate for climate } \\
\text { zones } 1 \text { thru 3, sealed exterior air barrier aligned with } \\
\text { RESNET Grade } 1 \text { Insulation fully supported. } \\
\text { Continuous top and bottom plates or sealed blocking. } \\
\text { 3.0 Floors between Conditioned and Exterior Spaces. } \\
\text { Air barrier is installed at any exposed fibrous insulation } \\
\text { edges. Insulation is installed to maintain permanent } \\
\text { contact with sub-floor above including necessary } \\
\text { supports (e.g., staves for blankets, netting for blown-in). } \\
\text { Blanket insulation is verified to have no gaps, voids or } \\
\text { compression. Blown-in insulation is verified to have } \\
\text { proper density with firm packing. } \\
\text { 4.0 Shafts. Openings to unconditioned space are fully } \\
\text { sealed with solid blocking or flashing and any } \\
\text { remaining gaps are sealed with caulk or foam (provide } \\
\text { fire-rated collars and caulking where required). } \\
\text { 5.0 Attic/Ceiling Interface. All attic penetrations and } \\
\text { dropped ceilings include a fully interior air barrier } \\
\text { aligned with insulation with any gaps fully sealed with } \\
\text { caulk, foam or tape. Movable insulation fits snugly in } \\
\text { opening and air barrier is fully gasketed. }\end{array}$ & \\
\hline Mandatory & $\begin{array}{l}\text { 402.4 Air } \\
\text { leakage. } 402.4 .2 \\
\text { Air sealing and } \\
\text { insulation. } \\
\text { 402.4.2.1 Testing } \\
\text { option. }\end{array}$ & $\begin{array}{l}\text { Building envelope air tightness and } \\
\text { insulation installation shall be } \\
\text { demonstrated to comply with one of the } \\
\text { following options given by Section } \\
\text { 402.4.2.1 or 402.4.2.2: } \\
\text { 402.4.2.1 Testing option. Building } \\
\text { envelope tightness and insulation } \\
\text { installation shall be considered acceptable } \\
\text { when tested air leakage is less than seven } \\
\text { air changes per hour (ACH) when tested } \\
\text { with a blower door at a pressure of } 50 \\
\text { pascals (1 psf). Testing shall occur after } \\
\text { rough in and after installation of } \\
\text { penetrations of the building envelope, } \\
\text { including penetrations for utilities, } \\
\text { plumbing, electrical, ventilation and } \\
\text { combustion appliances. } \\
\text { During testing: } \\
\text { 1. Exterior windows and doors, fireplace } \\
\text { and stove doors shall be closed, but not } \\
\text { sealed; } \\
\text { 2. Dampers shall be closed, but not sealed, } \\
\text { including exhaust, intake, makeup air, }\end{array}$ & $\begin{array}{l}\text { (Mandatory) Thermal Bypass Inspection Checklist } \\
\text { 1.0 Overall Air Barrier And Thermal Barrier Alignment. } \\
\text { Insulation shall be installed in full contact with sealed } \\
\text { interior and exterior air barrier except for alternate to } \\
\text { interior air barrier under item no. } 2 \text { (Walls Adjoining } \\
\text { Exterior Walls or Unconditioned Spaces). } \\
\text { 2.0 Walls Adjoining Exterior Walls or Unconditioned } \\
\text { Spaces. Fully insulated wall aligned with air barrier at } \\
\text { both interior and exterior, OR, alternate for climate } \\
\text { zones } 1 \text { thru 3, sealed exterior air barrier aligned with } \\
\text { RESNET Grade } 1 \text { Insulation fully supported. } \\
\text { Continuous top and bottom plates or sealed blocking. } \\
\text { 3.0 Floors between Conditioned and Exterior Spaces. } \\
\text { Air barrier is installed at any exposed fibrous insulation } \\
\text { edges. Insulation is installed to maintain permanent } \\
\text { contact with sub-floor above including necessary } \\
\text { supports (e.g., staves for blankets, netting for blown-in). } \\
\text { Blanket insulation is verified to have no gaps, voids or } \\
\text { compression. Blown-in insulation is verified to have } \\
\text { proper density with firm packing. } \\
\text { 4.0 Shafts. Openings to unconditioned space are fully } \\
\text { sealed with solid blocking or flashing and any } \\
\text { remaining gaps are sealed with caulk or foam (provide }\end{array}$ & $\begin{array}{l}\text { Mandatory - ENERGY STAR V2 requirement meets } \\
\text { the } 2009 \text { IECC requirement. }\end{array}$ \\
\hline
\end{tabular}




\begin{tabular}{|c|c|c|c|c|}
\hline $\begin{array}{l}\text { Requirement } \\
\text { Category }\end{array}$ & $\begin{array}{c}\text { IECC } \\
\text { Requirement } \\
\text { Reference }\end{array}$ & IECC & ES2 & Comments \\
\hline & & $\begin{array}{l}\text { backdraft and flue dampers; } \\
\text { 3. Interior doors shall be open; } \\
\text { 4. Exterior openings for continuous } \\
\text { ventilation systems and heat recovery } \\
\text { ventilators shall be closed and sealed; } \\
5 \text {. Heating and cooling system(s) shall be } \\
\text { turned off; } \\
\text { 6. HVAC ducts shall not be sealed; and } \\
\text { 7. Supply and return registers shall not be } \\
\text { sealed. }\end{array}$ & $\begin{array}{l}\text { fire-rated collars and caulking where required). } \\
5.0 \text { Attic/Ceiling Interface. All attic penetrations and } \\
\text { dropped ceilings include a fully interior air barrier } \\
\text { aligned with insulation with any gaps fully sealed with } \\
\text { caulk, foam or tape. Movable insulation fits snugly in } \\
\text { opening and air barrier is fully gasketed. }\end{array}$ & \\
\hline Mandatory & $\begin{array}{l}\text { 402.4 Air } \\
\text { leakage. } 402.4 .2 \\
\text { Air sealing and } \\
\text { insulation. } \\
\text { 402.4.2.2 Visual } \\
\text { inspection option. }\end{array}$ & $\begin{array}{l}\text { Building envelope air tightness and } \\
\text { insulation installation shall be } \\
\text { demonstrated to comply with one of the } \\
\text { following options given by Section } \\
402.4 .2 .1 \text { or } 402.4 .2 .2 \text { : } \\
\text { 402.4.2.2 Visual inspection option. } \\
\text { Building envelope tightness and insulation } \\
\text { installation shall be considered acceptable } \\
\text { when the items listed in Table } 402.4 .2 \text {, } \\
\text { applicable to the method of construction, } \\
\text { are field verified. Where required by the } \\
\text { code official, an approved party } \\
\text { independent from the installer of the } \\
\text { insulation shall inspect the air barrier and } \\
\text { insulation. }\end{array}$ & $\begin{array}{l}\text { (Mandatory) Thermal Bypass Inspection Checklist } \\
\text { 1.0 Overall Air Barrier And Thermal Barrier Alignment. } \\
\text { Insulation shall be installed in full contact with sealed } \\
\text { interior and exterior air barrier except for alternate to } \\
\text { interior air barrier under item no. } 2 \text { (Walls Adjoining } \\
\text { Exterior Walls or Unconditioned Spaces). } \\
\text { 2.0 Walls Adjoining Exterior Walls or Unconditioned } \\
\text { Spaces. Fully insulated wall aligned with air barrier at } \\
\text { both interior and exterior, OR, alternate for climate } \\
\text { zones } 1 \text { thru 3, sealed exterior air barrier aligned with } \\
\text { RESNET Grade } 1 \text { Insulation fully supported. } \\
\text { Continuous top and bottom plates or sealed blocking. } \\
\text { 3.0 Floors between Conditioned and Exterior Spaces. } \\
\text { Air barrier is installed at any exposed fibrous insulation } \\
\text { edges. Insulation is installed to maintain permanent } \\
\text { contact with sub-floor above including necessary } \\
\text { supports (e.g., staves for blankets, netting for blown-in). } \\
\text { Blanket insulation is verified to have no gaps, voids or } \\
\text { compression. Blown-in insulation is verified to have } \\
\text { proper density with firm packing. } \\
\text { 4.0 Shafts. Openings to unconditioned space are fully } \\
\text { sealed with solid blocking or flashing and any } \\
\text { remaining gaps are sealed with caulk or foam (provide } \\
\text { fire-rated collars and caulking where required). } \\
\text { 5.0 Attic/Ceiling Interface. All attic penetrations and } \\
\text { dropped ceilings include a fully interior air barrier } \\
\text { aligned with insulation with any gaps fully sealed with } \\
\text { caulk, foam or tape. Movable insulation fits snugly in } \\
\text { opening and air barrier is fully gasketed. }\end{array}$ & $\begin{array}{l}\text { Mandatory - ENERGY STAR V2 requirement meets } \\
\text { the } 2009 \text { IECC requirement. }\end{array}$ \\
\hline Mandatory & $\begin{array}{l}\text { 402.4 Air } \\
\text { leakage. } 402.4 .3 \\
\text { Fireplaces. } \\
\end{array}$ & $\begin{array}{l}\text { New wood-burning fireplaces shall have } \\
\text { gasketed doors and outdoor combustion } \\
\text { air. }\end{array}$ & - & Not explicitly mentioned in ENERGY STAR V2. \\
\hline Mandatory & $\begin{array}{l}\text { 402.4 Air } \\
\text { leakage. } 402.4 .4 \\
\text { Fenestration air } \\
\text { leakage. }\end{array}$ & $\begin{array}{l}\text { Windows, skylights and sliding glass } \\
\text { doors shall have an air infiltration rate of } \\
\text { no more than } 0.3 \mathrm{cfm} \text { per square foot }(1.5 \\
\mathrm{L} / \mathrm{s} / \mathrm{m} 2) \text {, and swinging doors no more than }\end{array}$ & $\begin{array}{l}\text { Prescriptive Path: The building thermal envelope must } \\
\text { meet the following requirements. Infiltration (ACH50): } \\
7 \text { in CZ's } 1-2,6 \text { in CZ's 3-4, } 5 \text { in CZ's 5-7, and } 4 \text { in CZ } \\
\text { 8. And insulation levels must meet or exceed the } 2004\end{array}$ & $\begin{array}{l}\text { Prescriptive - ENERGY STAR V2 requirement } \\
\text { meets the } 2009 \text { IECC requirement. }\end{array}$ \\
\hline
\end{tabular}




\begin{tabular}{|c|c|c|c|c|}
\hline $\begin{array}{l}\text { Requirement } \\
\text { Category }\end{array}$ & $\begin{array}{c}\text { IECC } \\
\text { Requirement } \\
\text { Reference } \\
\end{array}$ & IECC & ES2 & Comments \\
\hline & & $\begin{array}{l}0.5 \mathrm{cfm} \text { per square foot }(2.6 \mathrm{~L} / \mathrm{s} / \mathrm{m} 2) \text {, when } \\
\text { tested according to NFRC } 400 \text { or } \\
\text { AAMA/WDMA/CSA 101/I.S.2/A440 by } \\
\text { an accredited, independent laboratory and } \\
\text { listed and labeled by the manufacturer. } \\
\text { Exceptions: Site-built windows, skylights } \\
\text { and doors. }\end{array}$ & $\begin{array}{l}\text { IRC, and a completed Thermal Bypass Inspection } \\
\text { checklist must be performed. Envelope leakage must be } \\
\text { determined by a RESNET- certified rater using a } \\
\text { RESNET- approved testing protocol. Insulation levels } \\
\text { of a home must meet or exceed Sections N1102.1 and } \\
\text { N1102.2 of the } 2004 \text { IRC. These sections allow for } \\
\text { compliance to be determined by meeting prescriptive } \\
\text { insulation requirements, by using U-factor alternatives, } \\
\text { or by using a total UA alternative. These sections also } \\
\text { provide guidance and exceptions that may be used. } \\
\text { However, note that the U-factor for steel-frame } \\
\text { envelope assemblies addressed in Section N1102.2.4 } \\
\text { shall be calculated using the ASHRAE zone method, or } \\
\text { a method providing equivalent results, and not a series- } \\
\text { parallel path calculation method as is stated in the code. } \\
\text { Additionally, Section N1102.2.2, which allows for the } \\
\text { reduction of ceiling insulation in space constrained } \\
\text { roof/ceiling assemblies, shall be limited to } 500 \text { sq. ft. or } \\
20 \% \text { of ceiling area, whichever is less. In all cases, } \\
\text { insulation shall be inspected to Grade } 1 \text { installation as } \\
\text { defined in the RESNET Standards by a RESNET- } \\
\text { certified rater. }\end{array}$ & \\
\hline Mandatory & $\begin{array}{l}\text { 402.4 Air } \\
\text { leakage. } 402.4 .5 \\
\text { Recessed } \\
\text { lighting. }\end{array}$ & $\begin{array}{l}\text { Recessed luminaires installed in the } \\
\text { building thermal envelope shall be sealed } \\
\text { to limit air leakage between conditioned } \\
\text { and unconditioned spaces. All recessed } \\
\text { luminaires shall be IC-rated and labeled as } \\
\text { meeting ASTM E } 283 \text { when tested at } 1.57 \\
\text { psf ( } 75 \mathrm{~Pa}) \text { pressure differential with no } \\
\text { more than } 2.0 \mathrm{cfm}(0.944 \mathrm{~L} / \mathrm{s}) \text { of air } \\
\text { movement from the conditioned space to } \\
\text { the ceiling cavity. All recessed luminaires } \\
\text { shall be sealed with a gasket or caulk } \\
\text { between the housing and the interior wall } \\
\text { or ceiling covering. }\end{array}$ & $\begin{array}{l}\text { Prescriptive Path: The building thermal envelope must } \\
\text { meet the following requirements. Infiltration (ACH50): } \\
7 \text { in CZ's 1-2, } 6 \text { in CZ's 3-4, } 5 \text { in CZ's 5-7, and } 4 \text { in CZ } \\
\text { 8. And insulation levels must meet or exceed the } 2004 \\
\text { IRC, and a completed Thermal Bypass Inspection } \\
\text { checklist must be performed. Envelope leakage must be } \\
\text { determined by a RESNET- certified rater using a } \\
\text { RESNET- approved testing protocol. Insulation levels } \\
\text { of a home must meet or exceed Sections N1102.1 and } \\
\text { N1102.2 of the } 2004 \text { IRC. These sections allow for } \\
\text { compliance to be determined by meeting prescriptive } \\
\text { insulation requirements, by using U-factor alternatives, } \\
\text { or by using a total UA alternative. These sections also } \\
\text { provide guidance and exceptions that may be used. } \\
\text { However, note that the U-factor for steel-frame } \\
\text { envelope assemblies addressed in Section N1102.2.4 } \\
\text { shall be calculated using the ASHRAE zone method, or } \\
\text { a method providing equivalent results, and not a series- } \\
\text { parallel path calculation method as is stated in the code. } \\
\text { Additionally, Section N1102.2.2, which allows for the } \\
\text { reduction of ceiling insulation in space constrained } \\
\text { roof/ceiling assemblies, shall be limited to } 500 \text { sq. ft. or } \\
\text { 20\% of ceiling area, whichever is less. In all cases, } \\
\text { insulation shall be inspected to Grade } 1 \text { installation as }\end{array}$ & $\begin{array}{l}\text { Prescriptive - ENERGY STAR V2 requirement } \\
\text { meets the } 2009 \text { IECC requirement. }\end{array}$ \\
\hline
\end{tabular}




\begin{tabular}{|c|c|c|c|c|}
\hline $\begin{array}{l}\text { Requirement } \\
\text { Category }\end{array}$ & $\begin{array}{c}\text { IECC } \\
\text { Requirement } \\
\text { Reference }\end{array}$ & IECC & ES2 & Comments \\
\hline & & & $\begin{array}{l}\text { defined in the RESNET Standards by a RESNET- } \\
\text { certified rater. }\end{array}$ & \\
\hline Mandatory & $\begin{array}{l}\text { 402.5 Maximum } \\
\text { fenestration U- } \\
\text { factor and SHGC. }\end{array}$ & $\begin{array}{l}\text { The area-weighted average maximum } \\
\text { fenestration U-factor permitted using } \\
\text { trade-offs from Section } 402.1 .4 \text { or } 404 \\
\text { shall be } 0.48 \text { in Zones } 4 \text { and } 5 \text { and } 0.40 \text { in } \\
\text { Zones } 6 \text { through } 8 \text { for vertical fenestration, } \\
\text { and } 0.75 \text { in Zones } 4 \text { through } 8 \text { for } \\
\text { skylights. The area-weighted average } \\
\text { maximum fenestration SHGC permitted } \\
\text { using trade-offs from Section } 404 \text { in Zones } \\
1 \text { through } 3 \text { shall be } 0.50 \text {. }\end{array}$ & - & Not explicitly mentioned in ENERGY STAR V2. \\
\hline Mandatory & $\begin{array}{l}\text { 403.1 Controls. } \\
403.1 .1 \\
\text { Programmable } \\
\text { thermostat. }\end{array}$ & $\begin{array}{l}\text { At least one thermostat shall be provided } \\
\text { for each separate heating and cooling } \\
\text { system. } \\
\text { 403.1.1 Programmable thermostat. Where } \\
\text { the primary heating system is a forced-air } \\
\text { furnace, at least one thermostat per } \\
\text { dwelling unit shall be capable of } \\
\text { controlling the heating and cooling system } \\
\text { on a daily schedule to maintain different } \\
\text { temperature set points at different times of } \\
\text { the day. This thermostat shall include the } \\
\text { capability to set back or temporarily } \\
\text { operate the system to maintain zone } \\
\text { temperatures down to } 55^{\circ} \mathrm{F}\left(13^{\circ} \mathrm{C}\right) \text { or up to } \\
85^{\circ} \mathrm{F}\left(29^{\circ} \mathrm{C}\right) \text {. The thermostat shall initially } \\
\text { be programmed with a heating temperature } \\
\text { set point no higher than } 70^{\circ} \mathrm{F}\left(21^{\circ} \mathrm{C}\right) \text { and a } \\
\text { cooling temperature set point no lower } \\
\text { than } 78^{\circ} \mathrm{F}\left(26^{\circ} \mathrm{C}\right) \text {. }\end{array}$ & $\begin{array}{l}\text { Prescriptive Path: Energy Star qualified thermostat } \\
\text { (except for zones with radiant heat). }\end{array}$ & $\begin{array}{l}\text { Prescriptive - ENERGY STAR V2 requirement } \\
\text { meets the } 2009 \text { IECC requirement. }\end{array}$ \\
\hline Mandatory & $\begin{array}{l}\text { 403.1 Controls. } \\
403.1 .2 \text { Heat } \\
\text { pump } \\
\text { supplementary } \\
\text { heat. }\end{array}$ & $\begin{array}{l}\text { Heat pumps having supplementary } \\
\text { electric-resistance heat shall have controls } \\
\text { that, except during defrost, prevent } \\
\text { supplemental heat operation when the heat } \\
\text { pump compressor can meet the heating } \\
\text { load. }\end{array}$ & - & Not explicitly mentioned in ENERGY STAR V2. \\
\hline
\end{tabular}




\begin{tabular}{|c|c|c|c|c|}
\hline $\begin{array}{l}\text { Requirement } \\
\text { Category }\end{array}$ & $\begin{array}{c}\text { IECC } \\
\text { Requirement } \\
\text { Reference }\end{array}$ & IECC & ES2 & Comments \\
\hline Mandatory & $\begin{array}{l}403.2 \text { Ducts. } \\
\text { 403.2.2 Sealing. }\end{array}$ & $\begin{array}{l}\text { All ducts, air handlers, filter boxes and } \\
\text { building cavities used as ducts shall be } \\
\text { sealed. Joints and seams shall comply } \\
\text { with Section M1601.4.1 of the } \\
\text { International Residential Code. }\end{array}$ & $\begin{array}{l}\text { (Mandatory) Thermal Bypass Inspection Checklist } \\
\text { 4.0 Shafts. Openings to unconditioned space are fully } \\
\text { sealed with solid blocking or flashing and any } \\
\text { remaining gaps are sealed with caulk or foam (provide } \\
\text { fire-rated collars and caulking where required). }\end{array}$ & $\begin{array}{l}\text { Mandatory - ENERGY STAR V2 requirement meets } \\
\text { the } 2009 \text { IECC requirement. }\end{array}$ \\
\hline Mandatory & $\begin{array}{l}403.2 \text { Ducts. } \\
\text { 403.2.2 Sealing. } \\
(1-2)\end{array}$ & $\begin{array}{l}\text { Duct tightness shall be verified by either } \\
\text { of the following: } \\
1 \text {. Post-construction test: Leakage to } \\
\text { outdoors shall be less than or equal to } 8 \\
\text { cfm ( } 226.5 \mathrm{~L} / \mathrm{min}) \text { per } 100 \mathrm{ft} 2 \text { ( } 9.29 \mathrm{~m} 2) \\
\text { of conditioned floor area or a total leakage } \\
\text { less than or equal to } 12 \mathrm{cfm}(12 \mathrm{~L} / \mathrm{min}) \mathrm{per} \\
100 \mathrm{ft} 2 \text { ( } 9.29 \mathrm{~m} 2) \text { of conditioned floor area } \\
\text { when tested at a pressure differential of } 0.1 \\
\text { inches w.g. ( } 25 \mathrm{~Pa}) \text { across the entire } \\
\text { system, including the manufacturer's air } \\
\text { handler enclosure. All register boots shall } \\
\text { be taped or otherwise sealed during the } \\
\text { test. } \\
2 . \text { Rough-in test: Total leakage shall be } \\
\text { less than or equal to } 6 \text { cfm ( } 169.9 \mathrm{~L} / \mathrm{min}) \\
\text { per } 100 \mathrm{ft} 2 \text { ( } 9.29 \text { m2) of conditioned floor } \\
\text { area when tested at a pressure differential } \\
\text { of } 0.1 \text { inches w.g. ( } 25 \text { Pa) across the } \\
\text { roughed in system, including the } \\
\text { manufacturer's air handler enclosure. All } \\
\text { register boots shall be taped or otherwise } \\
\text { sealed during the test. If the air handler is } \\
\text { not installed at the time of the test, total } \\
\text { leakage shall be less than or equal to } 4 \text { cfm } \\
\text { (113.3 L/min) per } 100 \mathrm{ft} 2 \text { ( } 9.29 \text { m2) of } \\
\text { conditioned floor area. } \\
\text { Exceptions: Duct tightness test is not } \\
\text { required if the air handler and all ducts are } \\
\text { located within conditioned space. }\end{array}$ & $\begin{array}{l}\text { Performance Path: Ducts must be sealed and tested to } \\
\text { be } \leq 6 \mathrm{cfm} \text { outdoors / } 100 \text { sq. } \mathrm{ft} \text { of conditioned floor } \\
\text { area, as determined and documented by a RESNET- } \\
\text { certified rater using a RESNET- approved testing } \\
\text { protocol. If total duct leakage is } \leq 6 \mathrm{cfm} \text { to outdoors / } \\
100 \text { sq. ft. of conditioned floor area, then leakage to } \\
\text { outdoors does not need to be tested. Duct leakage } \\
\text { testing can be waived if all ducts and air handling } \\
\text { equipment are located in conditioned space (i.e., within } \\
\text { the home's air and thermal barriers) AND the envelope } \\
\text { leakage has been tested to be } \leq 3 \mathrm{ACH} 50 \text { of } \leq 0.25 \text { CFM } \\
50 \text { per sq. ft. of the building envelope. Note that } \\
\text { mechanical ventilation will be required in this situation. } \\
\text { Prescriptive Path: Leakage: } \leq 4 \text { cfm to outdoors / } 100 \\
\text { sq. ft. ; and R- } 6 \text { min. insulation on ducts in } \\
\text { unconditioned spaces. }\end{array}$ & $\begin{array}{l}\text { Performance and Prescriptive ENERGY STAR V2 } \\
\text { requirements exceed the } 2009 \text { IECC requirements. }\end{array}$ \\
\hline Mandatory & $\begin{array}{l}\text { 403.2 Ducts. } \\
\text { 403.2.3 Building } \\
\text { cavities. }\end{array}$ & $\begin{array}{l}\text { Building framing cavities shall not be used } \\
\text { as supply ducts. }\end{array}$ & $\begin{array}{l}\text { EPA recommends, but does not require, locating ducts } \\
\text { within the home's conditioned space (i.e., inside the air } \\
\text { and thermal barriers), and using a minimum of R-4 } \\
\text { insulation for ducts inside the conditioned space to } \\
\text { prevent condensation. }\end{array}$ & $\begin{array}{l}\text { ENERGY STAR V2 requirement meets the } 2009 \\
\text { IECC requirement. }\end{array}$ \\
\hline Mandatory & $\begin{array}{l}\text { 403.3 Mechanical } \\
\text { system piping } \\
\text { insulation. }\end{array}$ & $\begin{array}{l}\text { Mechanical system piping capable of } \\
\text { carrying fluids above } 105^{\circ} \mathrm{F}\left(41^{\circ} \mathrm{C}\right) \text { or } \\
\text { below55 } 55^{\circ} \mathrm{F}\left(13^{\circ} \mathrm{C}\right) \text { shall be insulated to a } \\
\text { minimum of R-3. }\end{array}$ & - & Not explicitly mentioned in ENERGY STAR V2. \\
\hline Mandatory & $\begin{array}{l}\text { 403.4 Circulating } \\
\text { hot water }\end{array}$ & $\begin{array}{l}\text { All circulating service hot water piping } \\
\text { shall be insulated to at least R-2. }\end{array}$ & $\begin{array}{l}\text { (Mandatory) 1.0 Where requirements of the local } \\
\text { codes, manufacturers' installation instructions, }\end{array}$ & $\begin{array}{l}\text { If the IECC } 2009 \text { has been adopted the ENERGY } \\
\text { STAR V2 requirement meets the } 2009 \text { IECC }\end{array}$ \\
\hline
\end{tabular}

D.18 


\begin{tabular}{|c|c|c|c|c|}
\hline $\begin{array}{l}\text { Requirement } \\
\text { Category }\end{array}$ & $\begin{array}{c}\text { IECC } \\
\text { Requirement } \\
\text { Reference }\end{array}$ & IECC & ES2 & Comments \\
\hline & systems. & $\begin{array}{l}\text { Circulating hot water systems shall include } \\
\text { an automatic or readily accessible manual } \\
\text { switch that can turn off the hot water } \\
\text { circulating pump when the system is not in } \\
\text { use. }\end{array}$ & $\begin{array}{l}\text { engineering documents, or regional ENERGY STAR } \\
\text { programs overlap with the requirements of these } \\
\text { guidelines, EPA offers the following guidance: } \\
\text { a. In cases where the overlapping requirements exceed } \\
\text { the ENERGY STAR guidelines, these overlapping } \\
\text { requirements shall be met; }\end{array}$ & $\begin{array}{l}\text { requirement. If not adopted then there is only } \\
\text { partial credit. }\end{array}$ \\
\hline Mandatory & $\begin{array}{l}403.5 \text { Mechanical } \\
\text { ventilation. }\end{array}$ & $\begin{array}{l}\text { Outdoor air intakes and exhausts shall } \\
\text { have automatic or gravity dampers that } \\
\text { close when the ventilation system is not } \\
\text { operating. }\end{array}$ & $\begin{array}{l}\text { (Mandatory) } 1.0 \text { Where requirements of the local } \\
\text { codes, manufacturers' installation instructions, } \\
\text { engineering documents, or regional ENERGY STAR } \\
\text { programs overlap with the requirements of these } \\
\text { guidelines, EPA offers the following guidance: } \\
\text { a. In cases where the overlapping requirements exceed } \\
\text { the ENERGY STAR guidelines, these overlapping } \\
\text { requirements shall be met; }\end{array}$ & $\begin{array}{l}\text { If the IECC } 2009 \text { has been adopted the ENERGY } \\
\text { STAR V2 requirement meets the } 2009 \text { IECC } \\
\text { requirement. If not adopted then there is only } \\
\text { partial credit. }\end{array}$ \\
\hline Mandatory & $\begin{array}{l}\text { 403.6 Equipment } \\
\text { sizing. }\end{array}$ & $\begin{array}{l}\text { Heating and cooling equipment shall be } \\
\text { sized in accordance with Section M1401.3 } \\
\text { of the International Residential Code. }\end{array}$ & $\begin{array}{l}\text { (Mandatory) 3.0 Cooling equipment shall be sized } \\
\text { according to the latest editions of ACCA Manuals J and } \\
\text { S, ASHRAE } 2001 \text { Handbook of Fundamentals, or an } \\
\text { equivalent procedure. Maximum oversizing limit for air } \\
\text { conditioners and heat pumps is } 15 \% \text { (with the exception } \\
\text { of heat pumps in Climate Zones } 5 \text { - } 8 \text {, where the } \\
\text { maximum oversizing limit is } 25 \% \text { ). The following } \\
\text { operating conditions shall be used in the sizing } \\
\text { calculations and verified where reviewed by the rater: } \\
\text { Outdoor temperatures shall be the } 99.0 \% \text { and } 1.0 \% \\
\text { design temperatures as published in the ASHRAE } \\
\text { Handbook of Fundamentals for the home's location or } \\
\text { most representative city for which design temperature } \\
\text { data are available; Indoor temperatures shall be } 75 \mathrm{~F} \text { for } \\
\text { cooling and } 70 \text { F for heating; Infiltration rate shall be } \\
\text { selected as "tight”, or the equivalent term. } \\
\text { In specifying equipment, the next available size may be } \\
\text { used. In addition, indoor and outdoor coils shall be } \\
\text { matched in accordance with ARI standards. }\end{array}$ & $\begin{array}{l}\text { ENERGY STAR V2 requirement only pertains to } \\
\text { the cooling loads. The } 2009 \text { IECC requirement is } \\
\text { only partially met. }\end{array}$ \\
\hline Mandatory & $\begin{array}{l}\text { 403.7 Systems } \\
\text { serving multiple } \\
\text { dwelling units. }\end{array}$ & $\begin{array}{l}\text { Systems serving multiple dwelling units } \\
\text { shall comply with Sections } 503 \text { and } 504 \text { in } \\
\text { lieu of Section } 403 .\end{array}$ & - & $\begin{array}{l}\text { Commercial requirements are outside of the scope } \\
\text { of this analysis. }\end{array}$ \\
\hline Mandatory & 403.9 Pools. & Pools shall be provided with energy- & - & Not explicitly mentioned in ENERGY STAR V2. \\
\hline
\end{tabular}




\begin{tabular}{|c|c|c|c|c|}
\hline $\begin{array}{l}\text { Requirement } \\
\text { Category }\end{array}$ & $\begin{array}{c}\text { IECC } \\
\text { Requirement } \\
\text { Reference }\end{array}$ & IECC & ES2 & Comments \\
\hline & $\begin{array}{l}\text { 403.9.1 Pool } \\
\text { heaters. }\end{array}$ & $\begin{array}{l}\text { conserving measures in accordance with } \\
\text { Sections } 403.9 .1 \text { through } 403.9 .3 \text {. } \\
403.9 .1 \text { Pool heaters. All pool heaters shall } \\
\text { be equipped with a readily accessible on- } \\
\text { off switch to allow shutting off the heater } \\
\text { without adjusting the thermostat setting. } \\
\text { Pool heaters fired by natural gas or LPG } \\
\text { shall not have continuously burning pilot } \\
\text { lights. }\end{array}$ & & \\
\hline Mandatory & $\begin{array}{l}\text { 403.9 Pools. } \\
\text { 403.9.2 Time } \\
\text { switches. }\end{array}$ & $\begin{array}{l}\text { Time switches that can automatically turn } \\
\text { off and on heaters and pumps according to } \\
\text { a preset schedule shall be installed on } \\
\text { swimming pool heaters and pumps. } \\
\text { Exceptions: } \\
\text { 1. Where public health standards require } \\
\text { 24-hour pump operation. } \\
\text { 2. Where pumps are required to operate } \\
\text { solar- and waste-heat-recovery pool } \\
\text { heating systems. }\end{array}$ & - & Not explicitly mentioned in ENERGY STAR V2. \\
\hline Mandatory & $\begin{array}{l}\text { 403.9 Pools. } \\
\text { 403.9.3 Pool } \\
\text { covers. }\end{array}$ & $\begin{array}{l}\text { Heated pools shall be equipped with a } \\
\text { vapor-retardant pool cover on or at the } \\
\text { water surface. Pools heated to more than } \\
90^{\circ} \mathrm{F}\left(32^{\circ} \mathrm{C}\right) \text { shall have a pool cover with a } \\
\text { minimum insulation value of R- } 12 \text {. } \\
\text { Exception: Pools deriving over } 60 \text { percent } \\
\text { of the energy for heating from site- } \\
\text { recovered energy or solar energy source. }\end{array}$ & - & Not explicitly mentioned in ENERGY STAR V2. \\
\hline Prescriptive & $\begin{array}{l}\text { 404.1 Lighting } \\
\text { equipment. }\end{array}$ & $\begin{array}{l}\text { A minimum of } 50 \text { percent of the lamps in } \\
\text { permanently installed lighting fixtures } \\
\text { shall be high-efficacy lamps. }\end{array}$ & $\begin{array}{l}\text { Prescriptive Path: Five or more Energy Star qualified } \\
\text { appliances, light fixtures, ceiling fans equipped with } \\
\text { lighting fixtures, water heaters, and/or ventilation fans } \\
\text { must be installed. Any combination of Energy Star } \\
\text { qualified products listed may be installed to meet this } \\
\text { requirement.... Energy Star qualified lighting fixtures } \\
\text { installed in the following locations shall not be counted: } \\
\text { storage rooms (e.g., closets, pantries, sheds), or garages. }\end{array}$ & $\begin{array}{l}\text { Prescriptive- ENERGY STAR V2 requirement } \\
\text { meets the } 2009 \text { IECC requirement only if over } 50 \% \\
\text { of the light fixtures selected are high efficacy lights. }\end{array}$ \\
\hline Performance & $\begin{array}{l}405.2 \text { Mandatory } \\
\text { requirements. }\end{array}$ & $\begin{array}{l}\text { Compliance with this section requires that } \\
\text { the mandatory provisions identified in } \\
\text { Section } 401.2 \text { be met. All supply and } \\
\text { return ducts not completely inside the } \\
\text { building thermal envelope shall be } \\
\text { insulated to a minimum of R- } 6 \text {. }\end{array}$ & - & Not explicitly mentioned in ENERGY STAR V2. \\
\hline Performance & $\begin{array}{l}405.3 \\
\text { Performance- } \\
\text { based } \\
\text { compliance. }\end{array}$ & $\begin{array}{l}\text { Compliance based on simulated energy } \\
\text { performance requires that a proposed } \\
\text { residence (proposed design) be shown to } \\
\text { have an annual energy cost that is less than } \\
\text { or equal to the annual energy cost of the }\end{array}$ & $\begin{array}{l}\text { Compliance based on using a performance approach to } \\
\text { meet a HERS Index of } 80 \text { in Climate Zones } 6 \text { - } 8 \text { and an } \\
85 \text { in Climate Zones } 1 \text { - } 5 \text {. }\end{array}$ & $\begin{array}{l}\text { Performance - ENERGY STAR V2 requirement } \\
\text { does not fully meet the } 2009 \text { IECC requirement. } \\
\text { Note that the allowance for equipment efficiency } \\
\text { trade-offs contained in the Performance Path are } \\
\text { not allowed in the IECC } 2009 \text {. }\end{array}$ \\
\hline
\end{tabular}




\begin{tabular}{|c|c|c|c|c|}
\hline $\begin{array}{l}\text { Requirement } \\
\text { Category }\end{array}$ & $\begin{array}{c}\text { IECC } \\
\text { Requirement } \\
\text { Reference }\end{array}$ & IECC & ES2 & Comments \\
\hline & & $\begin{array}{l}\text { standard reference design. Energy prices } \\
\text { shall be taken from a source approved by } \\
\text { the code official, such as the Department } \\
\text { of Energy, Energy Information } \\
\text { Administration's State Energy Price and } \\
\text { Expenditure Report. Code officials shall } \\
\text { be permitted to require time-of-use pricing } \\
\text { in energy cost calculations. } \\
\text { Exception: The energy use based on } \\
\text { source energy expressed in Btu or Btu per } \\
\text { square foot of conditioned floor area shall } \\
\text { be permitted to be substituted for the } \\
\text { energy cost. The source energy multiplier } \\
\text { for electricity shall be } 3.16 \text {. The source } \\
\text { energy multiplier for fuels other than } \\
\text { electricity shall be } 1.1 \text {. }\end{array}$ & & \\
\hline Performance & $\begin{array}{l}405.4 \\
\text { Documentation. } \\
405.4 .1 \\
\text { Compliance } \\
\text { software tools. } \\
\end{array}$ & $\begin{array}{l}\text { Documentation verifying that the methods } \\
\text { and accuracy of the compliance software } \\
\text { tools conform to the provisions of this } \\
\text { section shall be provided to the code } \\
\text { official. }\end{array}$ & - & Not explicitly mentioned in ENERGY STAR V2. \\
\hline Performance & $\begin{array}{l}405.4 \\
\text { Documentation. } \\
405.4 .2 \\
\text { Compliance } \\
\text { report. }\end{array}$ & $\begin{array}{l}\text { Compliance software tools shall generate a } \\
\text { report that documents that the proposed } \\
\text { design complies with Section } 405.3 \text {. }\end{array}$ & - & Not explicitly mentioned in ENERGY STAR V2. \\
\hline Performance & $\begin{array}{l}405.4 \\
\text { Documentation. } \\
405.4 .2 \\
\text { Compliance } \\
\text { report.(1) }\end{array}$ & $\begin{array}{l}\text { The compliance documentation shall } \\
\text { include the following information: } \\
\text { 1. Address or other identification of the } \\
\text { residence; }\end{array}$ & - & Not explicitly mentioned in ENERGY STAR V2. \\
\hline Performance & $\begin{array}{l}405.4 \\
\text { Documentation. } \\
405.4 .2 \\
\text { Compliance } \\
\text { report.(2) }\end{array}$ & $\begin{array}{l}\text { The compliance documentation shall } \\
\text { include the following information: } \\
2 \text {. An inspection checklist documenting } \\
\text { the building component characteristics of } \\
\text { the proposed design as listed in Table } \\
\text { 405.5.2(1). The inspection checklist shall } \\
\text { show results for both the standard } \\
\text { reference design and the proposed design, } \\
\text { and shall document all inputs entered by } \\
\text { the user necessary to reproduce the results; }\end{array}$ & - & Not explicitly mentioned in ENERGY STAR V2. \\
\hline Performance & $\begin{array}{l}405.4 \\
\text { Documentation. } \\
405.4 .2 \\
\text { Compliance } \\
\text { report.(3) } \\
\end{array}$ & $\begin{array}{l}\text { The compliance documentation shall } \\
\text { include the following information: } \\
\text { 3. Name of individual completing the } \\
\text { compliance report; and }\end{array}$ & - & Not explicitly mentioned in ENERGY STAR V2. \\
\hline
\end{tabular}




\begin{tabular}{|c|c|c|c|c|}
\hline $\begin{array}{l}\text { Requirement } \\
\text { Category }\end{array}$ & $\begin{array}{c}\text { IECC } \\
\text { Requirement } \\
\text { Reference }\end{array}$ & IECC & ES2 & Comments \\
\hline Performance & $\begin{array}{l}405.4 \\
\text { Documentation. } \\
405.4 .2 \\
\text { Compliance } \\
\text { report.(4) }\end{array}$ & $\begin{array}{l}\text { The compliance documentation shall } \\
\text { include the following information: } \\
\text { 4. Name and version of the compliance } \\
\text { software tool. } \\
\text { Exception: Multiple orientations. When an } \\
\text { otherwise identical building model is } \\
\text { offered in multiple orientations, } \\
\text { compliance for any orientation shall be } \\
\text { permitted by documenting that the } \\
\text { building meets the performance } \\
\text { requirements in each of the four cardinal } \\
\text { (north, east, south and west) orientations. }\end{array}$ & - & Not explicitly mentioned in ENERGY STAR V2. \\
\hline Performance & $\begin{array}{l}405.4 \\
\text { Documentation. } \\
405.4 .3 \\
\text { Additional } \\
\text { documentation. }\end{array}$ & $\begin{array}{l}\text { The code official shall be permitted to } \\
\text { require the following documents: } \\
\text { 1. Documentation of the building } \\
\text { component characteristics of the standard } \\
\text { reference design. } \\
\text { 2. A certification signed by the builder } \\
\text { providing the building component } \\
\text { characteristics of the proposed design as } \\
\text { given in Table } 405.5 .2(1) \text {. } \\
\text { 3. Documentation of the actual values used } \\
\text { in the software calculations for the } \\
\text { proposed design. }\end{array}$ & - & Not explicitly mentioned in ENERGY STAR V2. \\
\hline Performance & $\begin{array}{l}405.5 \text { Calculation } \\
\text { procedure. }\end{array}$ & $\begin{array}{l}\text { 405.5.1 General. Except as specified by } \\
\text { this section, the standard reference design } \\
\text { and proposed design shall be configured } \\
\text { and analyzed using identical methods and } \\
\text { techniques. } \\
\text { 405.5.2 Residence specifications. The } \\
\text { standard reference design and proposed } \\
\text { design shall be configured and analyzed as } \\
\text { specified by Table } 405.5 .2(1) \text {. Table } \\
\text { 405.5.2(1) shall include by reference all } \\
\text { notes contained in Table 402.1.1. }\end{array}$ & - & Not explicitly mentioned in ENERGY STAR V2. \\
\hline Performance & $\begin{array}{l}\text { 405.6 Calculation } \\
\text { software tools. } \\
\text { 405.6.1 Minimum } \\
\text { capabilities. }\end{array}$ & $\begin{array}{l}\text { Calculation procedures used to comply } \\
\text { with this section shall be software tools } \\
\text { capable of calculating the annual energy } \\
\text { consumption of all building elements that } \\
\text { differ between the standard reference } \\
\text { design and the proposed design and shall } \\
\text { include the following capabilities: }\end{array}$ & - & Not explicitly mentioned in ENERGY STAR V2. \\
\hline Performance & $\begin{array}{l}\text { 405.6 Calculation } \\
\text { software tools. } \\
\text { 405.6.1 Minimum } \\
\text { capabilities.(1) }\end{array}$ & $\begin{array}{l}\text { Calculation procedures ... and shall include } \\
\text { the following capabilities: } \\
\text { 1. Computer generation of the standard } \\
\text { reference design using only the input for }\end{array}$ & - & Not explicitly mentioned in ENERGY STAR V2. \\
\hline
\end{tabular}




\begin{tabular}{|c|c|c|c|c|}
\hline $\begin{array}{l}\text { Requirement } \\
\text { Category }\end{array}$ & $\begin{array}{c}\text { IECC } \\
\text { Requirement } \\
\text { Reference } \\
\end{array}$ & IECC & ES2 & Comments \\
\hline & & $\begin{array}{l}\text { the proposed design. The calculation } \\
\text { procedure shall not allow the user to } \\
\text { directly modify the building component } \\
\text { characteristics of the standard reference } \\
\text { design. }\end{array}$ & & \\
\hline Performance & $\begin{array}{l}\text { 405.6 Calculation } \\
\text { software tools. } \\
\text { 405.6.1 Minimum } \\
\text { capabilities.(2) }\end{array}$ & $\begin{array}{l}\text { Calculation procedures ... and shall include } \\
\text { the following capabilities: } \\
\text { 2. Calculation of whole-building (as a } \\
\text { single zone) sizing for the heating and } \\
\text { cooling equipment in the standard } \\
\text { reference design residence in accordance } \\
\text { with Section M1401.3 of the International } \\
\text { Residential Code. }\end{array}$ & - & Not explicitly mentioned in ENERGY STAR V2. \\
\hline Performance & $\begin{array}{l}\text { 405.6 Calculation } \\
\text { software tools. } \\
\text { 405.6.1 Minimum } \\
\text { capabilities.(3) }\end{array}$ & $\begin{array}{l}\text { Calculation procedures ... and shall include } \\
\text { the following capabilities: } \\
\text { 3. Calculations that account for the effects } \\
\text { of indoor and outdoor temperatures and } \\
\text { part-load ratios on the performance of } \\
\text { heating, ventilating and air-conditioning } \\
\text { equipment based on climate and } \\
\text { equipment sizing. }\end{array}$ & - & Not explicitly mentioned in ENERGY STAR V2. \\
\hline Performance & $\begin{array}{l}\text { 405.6 Calculation } \\
\text { software tools. } \\
\text { 405.6.1 Minimum } \\
\text { capabilities.(4) }\end{array}$ & $\begin{array}{l}\text { Calculation procedures ... and shall include } \\
\text { the following capabilities: } \\
\text { 4. Printed code official inspection } \\
\text { checklist listing each of the proposed } \\
\text { design component characteristics from } \\
\text { Table } 405.5 .2(1) \text { determined by the } \\
\text { analysis to provide compliance, along with } \\
\text { their respective performance ratings (e.g., } \\
\text { R-value, U-factor, SHGC, HSPF, AFUE, } \\
\text { SEER, EF, etc.). }\end{array}$ & - & Not explicitly mentioned in ENERGY STAR V2. \\
\hline Performance & $\begin{array}{l}\text { 405.6 Calculation } \\
\text { software tools. } \\
\text { 405.6.2 Specific } \\
\text { approval. }\end{array}$ & $\begin{array}{l}\text { Performance analysis tools meeting the } \\
\text { applicable sections of Section } 405 \text { shall be } \\
\text { permitted to be approved. Tools are } \\
\text { permitted to be approved based on meeting } \\
\text { a specified threshold for a jurisdiction. The } \\
\text { code official shall be permitted to approve } \\
\text { tools for a specified application or limited } \\
\text { scope. }\end{array}$ & - & Not explicitly mentioned in ENERGY STAR V2. \\
\hline Performance & $\begin{array}{l}405.6 \text { Calculation } \\
\text { software tools. } \\
405.6 .3 \text { Input } \\
\text { values. }\end{array}$ & $\begin{array}{l}\text { When calculations require input values not } \\
\text { specified by Sections } 402,403,404 \text { and } \\
405 \text {, those input values shall be taken from } \\
\text { an approved source. }\end{array}$ & - & Not explicitly mentioned in ENERGY STAR V2. \\
\hline
\end{tabular}


Appendix E

\section{ENERGY STAR Version 2.5 Mapping}




\begin{tabular}{|c|c|c|c|c|}
\hline $\begin{array}{c}\text { Requirement } \\
\text { Category }\end{array}$ & $\begin{array}{c}\text { Requirement } \\
\text { Reference }\end{array}$ & IECC 2009 & ES2.5 & Comments \\
\hline \multirow[t]{3}{*}{ Prescriptive } & $\begin{array}{l}\text { 402.1.1 Insulation } \\
\text { and fenestration } \\
\text { criteria. }\end{array}$ & $\begin{array}{l}\text { The building thermal envelope shall meet } \\
\text { the requirements of Table } 402.1 .1 \text { based } \\
\text { on the climate zone specified in Chapter } \\
3 \text {. }\end{array}$ & $\begin{array}{l}\text { (Recommended) Thermal Enclosure System } \\
\text { Rater Checklist } \\
\text { 1.0 High-Performance Fenestration } \\
\text { 1.1 Prescriptive Path: Fenestration shall meet or } \\
\text { exceed ENERGY STAR requirements. } \\
\text { 1.2 Performance Path: Fenestration shall meet or } \\
\text { exceed } 2009 \text { IECC requirements. } \\
\text { 2.0 Quality-Installed Insulation } \\
\text { 2.1 Ceiling, wall, floor, and slab insulation levels } \\
\text { shall meet or exceed 2009 IECC levels. } \\
\text { 2.2 All ceiling, wall, floor, and slab insulation shall } \\
\text { achieve RESNET- defined Grade I installation, or } \\
\text { alternatively, Grade II for surfaces with insulated } \\
\text { sheathing. } \\
\text { V2.5 Program Requirements: The Version } 2 \text { slab } \\
\text { edge insulation exemption remains only for Version } \\
\text { 2.5; therefore, up to 25\% of the slab edge may be } \\
\text { uninsulated in } 2009 \text { IECC Climate Zones } 4 \text { and } 5 \text {. }\end{array}$ & $\begin{array}{l}\text { Optional - ENERGY STAR V2.5 requirement does } \\
\text { not meet the } 2009 \text { IECC requirement unless the } \\
\text { feature is complied with. Note V2.5 Program } \\
\text { requirements: Inspection Checklist - Thermal } \\
\text { Enclosure System. All items on this inspection } \\
\text { checklist shall be completed (i.e., the rater must } \\
\text { indicate whether each item must be corrected, } \\
\text { whether the item is builder or rater approved, or } \\
\text { whether the item is not applicable to the home). } \\
\text { Homes shall pass all requirements of 'Section 3: } \\
\text { Fully-Aligned Air Barriers' and 'Section 5: Air } \\
\text { Sealing' to qualify. Noncompliance with items in } \\
\text { other sections of this checklist shall not prevent } \\
\text { homes from earning the label. } \\
\text { Also note: The allowance for } 25 \% \text { of the slab } \\
\text { edge to be uninsulated will not comply with the } \\
\text { prescriptive requirements of the code as there is } \\
\text { no allowance for the installation of partial } \\
\text { insulation. }\end{array}$ \\
\hline & $\begin{array}{l}\text { 402.1.2 R-value } \\
\text { computation. }\end{array}$ & $\begin{array}{l}\text { Insulation material used in layers, such as } \\
\text { framing cavity insulation and insulating } \\
\text { sheathing, shall be summed to compute } \\
\text { the component R-value. The } \\
\text { manufacturer's settled R-value shall be } \\
\text { used for blown insulation. Computed R- } \\
\text { values shall not include an R-value for } \\
\text { other building materials or air films. }\end{array}$ & $\begin{array}{l}\text { (Recommended) Thermal Enclosure System } \\
\text { Rater Checklist } \\
\text { 1.0 High-Performance Fenestration } \\
\text { 1.1 Prescriptive Path: Fenestration shall meet or } \\
\text { exceed ENERGY STAR* requirements. } \\
\text { 1.2 Performance Path: Fenestration shall meet or } \\
\text { exceed } 2009 \text { IECC requirements. } \\
\text { *ENERGY STAR Program Requirements for } \\
\text { Residential Windows, Doors, and Skylights - } \\
\text { Version 5.0 as outlined at } \\
\text { www.energystar.gov/windows. }\end{array}$ & $\begin{array}{l}\text { Optional - Energy Star V2.5 requirement does not } \\
\text { meet the } 2009 \text { IECC requirements unless the } \\
\text { feature is complied with. Note V2.5 Program } \\
\text { requirements: Inspection Checklist - Thermal } \\
\text { Enclosure System. All items on this inspection } \\
\text { checklist shall be completed (i.e., the rater must } \\
\text { indicate whether each item must be corrected, } \\
\text { whether the item is builder or rater approved, or } \\
\text { whether the item is not applicable to the home). } \\
\text { Homes shall pass all requirements of 'Section 3: } \\
\text { Fully-Aligned Air Barriers' and 'Section 5: Air } \\
\text { Sealing' to qualify. Noncompliance with items in } \\
\text { other sections of this checklist shall not prevent } \\
\text { homes from earning the label. }\end{array}$ \\
\hline & $\begin{array}{l}\text { 402.1.3 U-factor } \\
\text { alternative. }\end{array}$ & $\begin{array}{l}\text { An assembly with a U-factor equal to or } \\
\text { less than that specified in Table } 402.1 .3 \\
\text { shall be permitted as an alternative to the } \\
\text { R-value in Table } 402.1 .1 \text {. }\end{array}$ & $\begin{array}{l}\text { (Recommended) Program Requirements } \\
\text { 6.0 Insulation levels in a home shall meet or exceed } \\
\text { the component insulation requirements in the } 2009 \\
\text { IECC - Table 402.1.1. The following exceptions } \\
\text { apply: } \\
\text { a. Steel-frame ceilings, walls, and floors shall meet } \\
\text { the insulation requirements of the } 2009 \text { IECC - } \\
\text { Table } 402.2 .5 \text {. In CZ } 1 \text { and 2, the continuous } \\
\text { insulation requirements in this table shall be } \\
\text { permitted to be reduced to R-3 for steel-frame wall } \\
\text { assemblies with studs spaced at } 24 \text { ” on center. This } \\
\text { exception shall not apply if the alternative } \\
\text { calculations in d) are used; } \\
\text { b. For ceilings with attic spaces, R-30 shall satisfy }\end{array}$ & $\begin{array}{l}\text { Optional - ENERGY STAR V2.5 requirement does } \\
\text { not meet the } 2009 \text { IECC requirement unless the } \\
\text { feature is complied with. Note V2.5 Program } \\
\text { requirements: Inspection Checklist - Thermal } \\
\text { Enclosure System. All items on this inspection } \\
\text { checklist shall be completed (i.e., the rater must } \\
\text { indicate whether each item must be corrected, } \\
\text { whether the item is builder or rater approved, or } \\
\text { whether the item is not applicable to the home). } \\
\text { Homes shall pass all requirements of 'Section 3: } \\
\text { Fully-Aligned Air Barriers' and 'Section 5: Air } \\
\text { Sealing' to qualify. Noncompliance with items in } \\
\text { other sections of this checklist shall not prevent } \\
\text { homes from earning the label. }\end{array}$ \\
\hline
\end{tabular}




\begin{tabular}{|c|c|c|c|c|}
\hline $\begin{array}{l}\text { Requirement } \\
\text { Category }\end{array}$ & $\begin{array}{l}\text { Requirement } \\
\text { Reference }\end{array}$ & IECC 2009 & ES2.5 & Comments \\
\hline & & & $\begin{array}{l}\text { the requirement for R-38 and R-38 shall satisfy the } \\
\text { requirement for R- } 49 \text { wherever the full height of } \\
\text { uncompressed insulation at the lower R-value } \\
\text { extends over the wall top plate at the eaves. This } \\
\text { exemption shall not apply if the alternative } \\
\text { calculations in d) are used; } \\
\text { c. For ceilings without attic spaces, R-30 shall } \\
\text { satisfy the requirement for any required value above } \\
\text { R-30 if the design of the roof/ceiling assembly does } \\
\text { not provide sufficient space for the required } \\
\text { insulation value. This exemption shall be limited to } \\
500 \text { square ft. or } 20 \% \text { of the total insulated ceiling } \\
\text { area, whichever is less. This exemption shall not } \\
\text { apply if the alternative calculations in d) are used; } \\
\text { d. An alternative equivalent U-factor or total UA } \\
\text { calculation may also be used to demonstrate } \\
\text { compliance, as follows: An assembly with a U- } \\
\text { factor equal or less than specified in } 2009 \text { IECC } \\
\text { Table } 402.1 .3 \text { complies. } \\
\text { V2.5 Program Requirements: The Version } 2 \text { slab } \\
\text { edge insulation exemption remains only for Version } \\
2.5 \text {; therefore, up to } 25 \% \text { of the slab edge may be } \\
\text { uninsulated in } 2009 \text { IECC Climate Zones } 4 \text { and } 5 \text {. }\end{array}$ & $\begin{array}{l}\text { Also note: The allowance for } 25 \% \text { of the slab } \\
\text { edge to be uninsulated with not comply with the } \\
\text { prescriptive requirements of the code as there is } \\
\text { no allowance for the installation of partial } \\
\text { insulation. }\end{array}$ \\
\hline Prescriptive & $\begin{array}{l}\text { 402.1.4 Total UA } \\
\text { alternative. }\end{array}$ & $\begin{array}{l}\text { If the total building thermal envelope } \\
\text { UA... is less than or equal to the total UA } \\
\text { resulting from using the U-factors in } \\
\text { Table } 402.1 .3 . . . \text {, the building shall be } \\
\text { considered in compliance with Table } \\
\text { 402.1.1. The UA calculation shall be } \\
\text { done using a method consistent with the } \\
\text { ASHRAE Handbook of Fundamentals } \\
\text { and shall include the thermal bridging } \\
\text { effects of framing materials. The SHGC } \\
\text { requirements shall be met in addition to } \\
\text { the UA compliance. }\end{array}$ & $\begin{array}{l}\text { (Recommended) Program Requirements } \\
6.0 \text { Insulation levels in a home shall meet or exceed } \\
\text { the component insulation requirements in the } 2009 \\
\text { IECC - Table 402.1.1. The following exceptions } \\
\text { apply: } \\
\text { a. Steel-frame ceilings, walls, and floors shall meet } \\
\text { the insulation requirements of the } 2009 \text { IECC - } \\
\text { Table } 402.2 .5 \text {. In CZ } 1 \text { and 2, the continuous } \\
\text { insulation requirements in this table shall be } \\
\text { permitted to be reduced to R-3 for steel-frame wall } \\
\text { assemblies with studs spaced at } 24 \text { ” on center. This } \\
\text { exception shall not apply if the alternative } \\
\text { calculations in d) are used; } \\
\text { b. For ceilings with attic spaces, R-30 shall satisfy } \\
\text { the requirement for R-38 and R-38 shall satisfy the } \\
\text { requirement for R- } 49 \text { wherever the full height of } \\
\text { uncompressed insulation at the lower R-value } \\
\text { extends over the wall top plate at the eaves. This } \\
\text { exemption shall not apply if the alternative } \\
\text { calculations in d) are used; } \\
\text { c. For ceilings without attic spaces, R-30 shall } \\
\text { satisfy the requirement for any required value above } \\
\text { R-30 if the design of the roof/ceiling assembly does } \\
\text { not provide sufficient space for the required }\end{array}$ & $\begin{array}{l}\text { Optional - ENERGY STAR V2.5 requirement does } \\
\text { not meet the } 2009 \text { IECC requirement unless the } \\
\text { feature is complied with. Note V2.5 Program } \\
\text { requirements: Inspection Checklist - Thermal } \\
\text { Enclosure System. All items on this inspection } \\
\text { checklist shall be completed (i.e., the rater must } \\
\text { indicate whether each item must be corrected, } \\
\text { whether the item is builder or rater approved, or } \\
\text { whether the item is not applicable to the home). } \\
\text { Homes shall pass all requirements of 'Section 3: } \\
\text { Fully-Aligned Air Barriers' and 'Section 5: Air } \\
\text { Sealing' to qualify. Noncompliance with items in } \\
\text { other sections of this checklist shall not prevent } \\
\text { homes from earning the label. }\end{array}$ \\
\hline
\end{tabular}




\begin{tabular}{|c|c|c|c|c|}
\hline $\begin{array}{l}\text { Requirement } \\
\text { Category }\end{array}$ & $\begin{array}{l}\text { Requirement } \\
\text { Reference }\end{array}$ & IECC 2009 & ES2.5 & Comments \\
\hline & & & $\begin{array}{l}\text { insulation value. This exemption shall be limited to } \\
500 \text { square ft. or } 20 \% \text { of the total insulated ceiling } \\
\text { area, whichever is less. This exemption shall not } \\
\text { apply if the alternative calculations in d) are used; } \\
\text { d. An alternative equivalent U-factor or total UA } \\
\text { calculation may also be used to demonstrate } \\
\text { compliance, as follows: An assembly with a U- } \\
\text { factor equal or less than specified in } 2009 \text { IECC } \\
\text { Table } 402.1 .3 \text { complies. }\end{array}$ & \\
\hline Prescriptive & $\begin{array}{l}402.2 \text { Specific } \\
\text { insulation } \\
\text { requirements. } \\
\text { 402.2.1 Ceilings with } \\
\text { attic spaces. }\end{array}$ & $\begin{array}{l}\text { When Section } 402.1 .1 \text { would require R- } \\
38 \text { in the ceiling, R-30 shall be deemed to } \\
\text { satisfy the requirement for R-38 } \\
\text { whenever the full height of } \\
\text { uncompressed R-30 insulation extends } \\
\text { over the wall top plate at the eaves. } \\
\text { Similarly, R-38 shall be deemed to } \\
\text { satisfy the requirements for R- } 49 \text { where } \\
\text { ever the full height of uncompressed R- } \\
38 \text { insulation extends over the top plate at } \\
\text { the eaves. This reduction shall not apply } \\
\text { to the U-factor alternative approach in } \\
\text { Section } 402.1 .3 \text { and the total UA } \\
\text { alternative in Section } 402.1 .4 \text {. }\end{array}$ & $\begin{array}{l}\text { (Recommended) Thermal Enclosure System } \\
\text { Rater Checklist } \\
2.0 \text { Quality Installed Insulation. } \\
2.1 \text { Ceiling, wall, floor, and slab insulation levels } \\
\text { shall meet or exceed } 2009 \text { IECC levels. For ceilings } \\
\text { with attic spaces, R-30 shall satisfy the requirement } \\
\text { for R-38 and R-38 shall satisfy the requirement for } \\
\text { R-49 wherever the full height of uncompressed } \\
\text { insulation at the lower R-value extends over the wall } \\
\text { top plate at the eaves. This exemption shall not } \\
\text { apply if the alternative calculations in D) are used. } \\
\text { D) An alternative equivalent U-factor or total UA } \\
\text { calculation may also be used to demonstrate } \\
\text { compliance, as follows: An assembly with a U- } \\
\text { factor equal or less than specified in } 2009 \text { IECC } \\
\text { Table } 402.1 .3 \text { complies. A total building thermal } \\
\text { envelope UA that is less than or equal to the total } \\
\text { UA resulting from the U-factors in Table } 402.1 .3 \\
\text { also complies. The insulation levels of all non- } \\
\text { fenestration components (i.e., ceilings, walls, floors, } \\
\text { and slabs) can be traded off using the UA approach } \\
\text { under both the Prescriptive and the Performance } \\
\text { path. Note that fenestration products (i.e., windows, } \\
\text { skylights, doors) shall not be included in this } \\
\text { calculation. Also, not that while ceiling and slab } \\
\text { insulation can be included in trade-off calculations, } \\
\text { the R-value must meet or exceed the minimum } \\
\text { values listed in items } 4.1 \text { through } 4.3 \text { of the checklist } \\
\text { to provide an effective thermal break, regardless of } \\
\text { the UA tradeoffs calculated. The UA calculation } \\
\text { shall be done using a method consistent with the } \\
\text { ASHRAE Handbook of Fundamentals and shall } \\
\text { include the thermal bridging effects of framing } \\
\text { materials. The calculation for a steel-frame envelope } \\
\text { assembly shall use a series-parallel path calculation } \\
\text { method. } \\
\text { V2.5 Program Requirements: The Version } 2 \text { slab } \\
\text { edge insulation exemption remains only for Version }\end{array}$ & $\begin{array}{l}\text { Optional - ENERGY STAR V2.5 requirement does } \\
\text { not meet the } 2009 \text { IECC requirement unless the } \\
\text { feature is complied with. Note V2.5 Program } \\
\text { requirements: Inspection Checklist - Thermal } \\
\text { Enclosure System. All items on this inspection } \\
\text { checklist shall be completed (i.e., the rater must } \\
\text { indicate whether each item must be corrected, } \\
\text { whether the item is builder or rater approved, or } \\
\text { whether the item is not applicable to the home). } \\
\text { Homes shall pass all requirements of 'Section } 3: \\
\text { Fully-Aligned Air Barriers' and 'Section 5: Air } \\
\text { Sealing' to qualify. Noncompliance with items in } \\
\text { other sections of this checklist shall not prevent } \\
\text { homes from earning the label. } \\
\text { Also note: The allowance for } 25 \% \text { of the slab } \\
\text { edge to be uninsulated with not comply with the } \\
\text { prescriptive requirements of the code as there is } \\
\text { no allowance for the installation of partial } \\
\text { insulation. }\end{array}$ \\
\hline
\end{tabular}




\begin{tabular}{|c|c|c|c|c|}
\hline $\begin{array}{l}\text { Requirement } \\
\text { Category }\end{array}$ & $\begin{array}{l}\text { Requirement } \\
\text { Reference }\end{array}$ & IECC 2009 & ES2.5 & Comments \\
\hline & & & $\begin{array}{l}\text { 2.5; therefore, up to } 25 \% \text { of the slab edge may be } \\
\text { uninsulated in } 2009 \text { IECC Climate Zones } 4 \text { and } 5 \text {. }\end{array}$ & \\
\hline Prescriptive & $\begin{array}{l}402.2 \text { Specific } \\
\text { insulation } \\
\text { requirements. } \\
\text { 402.2.2 Ceilings } \\
\text { without attic spaces. }\end{array}$ & $\begin{array}{l}\text { Where Section } 402.1 .1 \text { would require } \\
\text { insulation levels above R-30 and the } \\
\text { design often roof/ceiling assemble does } \\
\text { not allow sufficient space for the required } \\
\text { insulation, the minimum required } \\
\text { insulation for such roof/ceiling } \\
\text { assemblies shall be R-30. This reduction } \\
\text { of insulation from the requirements of } \\
\text { Section } 402.1 .1 \text { shall be limited to } 500 \\
\text { square feet of } 20 \text { percent of the total } \\
\text { insulated ceiling area, whichever is less. } \\
\text { This reduction shall not apply to the U- } \\
\text { factor alternative approach in Section } \\
402.1 .3 \text { and the total UA alternative in } \\
\text { Section } 4-2.1 .4 \text {. }\end{array}$ & $\begin{array}{l}\text { (Recommended) Thermal Enclosure System } \\
\text { Rater Checklist } \\
\text { 2.0 Quality Installed Insulation. } \\
\text { 2.1 Ceiling, wall, floor, and slab insulation levels } \\
\text { shall meet or exceed } 2009 \text { IECC levels. For ceilings } \\
\text { without attic spaces, R-30 shall satisfy the } \\
\text { requirement for any required value above R-30 if } \\
\text { the design of the roof/ceiling assembly does not } \\
\text { provide sufficient space for the required insulation } \\
\text { value. This exception shall be limited to } 500 \text { square } \\
\text { ft. or } 20 \% \text { of the total insulated ceiling area, } \\
\text { whichever is less. This exemption shall not apply if } \\
\text { the alternative calculations in D) are used. } \\
\text { V2.5 Program Requirements: The Version } 2 \text { slab } \\
\text { edge insulation exemption remains only for Version } \\
\text { 2.5; therefore, up to } 25 \% \text { of the slab edge may be } \\
\text { uninsulated in } 2009 \text { IECC Climate Zones } 4 \text { and } 5 \text {. }\end{array}$ & $\begin{array}{l}\text { Optional - ENERGY STAR V2.5 requirement does } \\
\text { not meet the } 2009 \text { IECC requirement unless the } \\
\text { feature is complied with. Note V2.5 Program } \\
\text { requirements: Inspection Checklist - Thermal } \\
\text { Enclosure System. All items on this inspection } \\
\text { checklist shall be completed (i.e., the rater must } \\
\text { indicate whether each item must be corrected, } \\
\text { whether the item is builder or rater approved, or } \\
\text { whether the item is not applicable to the home). } \\
\text { Homes shall pass all requirements of 'Section 3: } \\
\text { Fully-Aligned Air Barriers' and 'Section 5: Air } \\
\text { Sealing' to qualify. Noncompliance with items in } \\
\text { other sections of this checklist shall not prevent } \\
\text { homes from earning the label. } \\
\text { Also note: The allowance for } 25 \% \text { of the slab } \\
\text { edge to be uninsulated with not comply with the } \\
\text { prescriptive requirements of the code as there is } \\
\text { no allowance for the installation of partial } \\
\text { insulation. }\end{array}$ \\
\hline Prescriptive & $\begin{array}{l}\text { 402.2 Specific } \\
\text { insulation } \\
\text { requirements. } \\
\text { 402.2.3 Access } \\
\text { hatches and doors. }\end{array}$ & $\begin{array}{l}\text { Access doors from conditioned spaces to } \\
\text { unconditioned spaces (e.g., attics and } \\
\text { crawl spaces) shall be weatherstripped } \\
\text { and insulated to a level equivalent to the } \\
\text { insulation on the surrounding surfaces. } \\
\text { Access shall be provided to all equipment } \\
\text { that prevents damaging or compressing } \\
\text { the insulation. A wood framed or } \\
\text { equivalent baffle or retainer is required to } \\
\text { be provided when loose fill insulation is } \\
\text { installed, the purpose of which is to } \\
\text { prevent the loose fill insulation from } \\
\text { spilling into the living space when the } \\
\text { attic access is opened, and to provide a } \\
\text { permanent means of maintaining the } \\
\text { installed R-value of the loose fill } \\
\text { insulation. }\end{array}$ & $\begin{array}{l}\text { (Recommended) Thermal Enclosure System } \\
\text { Rater Checklist } \\
\text { 2.0 Quality Installed Insulation. 2.1 Ceiling, wall, } \\
\text { floor, and slab insulation levels shall meet or exceed } \\
\text { 2009 IECC levels. 5.0 Air Sealing 5.3 Other } \\
\text { Openings 5.3.2 Attic access panels and drop-down } \\
\text { stairs equipped with a durable } \geq \text { R-10 insulated } \\
\text { cover that is gasketed (i.e., not caulked) to produce } \\
\text { continuous air seal when occupant is not accessing } \\
\text { the attic. } \\
\text { V2.5 Program Requirements: The Version } 2 \text { slab } \\
\text { edge insulation exemption remains only for Version } \\
\text { 2.5; therefore, up to 25\% of the slab edge may be } \\
\text { uninsulated in } 2009 \text { IECC Climate Zones } 4 \text { and } 5 .\end{array}$ & $\begin{array}{l}\text { Optional - ENERGY STAR V2.5 requirement does } \\
\text { not meet the } 2009 \text { IECC requirement unless the } \\
\text { feature is complied with. Note V2.5 Program } \\
\text { requirements: Inspection Checklist - Thermal } \\
\text { Enclosure System. All items on this inspection } \\
\text { checklist shall be completed (i.e., the rater must } \\
\text { indicate whether each item must be corrected, } \\
\text { whether the item is builder or rater approved, or } \\
\text { whether the item is not applicable to the home). } \\
\text { Homes shall pass all requirements of 'Section 3: } \\
\text { Fully-Aligned Air Barriers' and 'Section 5: Air } \\
\text { Sealing' to qualify. Noncompliance with items in } \\
\text { other sections of this checklist shall not prevent } \\
\text { homes from earning the label. } \\
\text { Also note: The allowance for } 25 \% \text { of the slab } \\
\text { edge to be uninsulated with not comply with the } \\
\text { prescriptive requirements of the code as there is } \\
\text { no allowance for the installation of partial } \\
\text { insulation. }\end{array}$ \\
\hline Prescriptive & $\begin{array}{l}\text { 402.2 Specific } \\
\text { insulation } \\
\text { requirements. } \\
\text { 402.2.4 Mass walls. }\end{array}$ & $\begin{array}{l}\text { Mass walls for the purposes of this } \\
\text { chapter shall be considered above-grade } \\
\text { walls of concrete block, concrete, } \\
\text { insulated concrete form (ICF), masonry } \\
\text { cavity, brick (other than brick veneer), } \\
\text { earth (adobe, compressed earth block, } \\
\text { rammed earth) and solid timber/logs. }\end{array}$ & $\begin{array}{l}\text { (Recommended) Thermal Enclosure System } \\
\text { Rater Checklist } \\
\text { 2.0 Quality Installed Insulation. } \\
\text { 2.1 Ceiling, wall, floor, and slab insulation levels } \\
\text { shall meet or exceed } 2009 \text { IECC levels. } \\
\text { V2.5 Program Requirements: The Version } 2 \text { slab } \\
\text { edge insulation exemption remains only for Version }\end{array}$ & $\begin{array}{l}\text { Optional - ENERGY STAR V2.5 requirement does } \\
\text { not meet the } 2009 \text { IECC requirement unless the } \\
\text { feature is complied with. Note V2.5 Program } \\
\text { requirements: Inspection Checklist - Thermal } \\
\text { Enclosure System. All items on this inspection } \\
\text { checklist shall be completed (i.e., the rater must } \\
\text { indicate whether each item must be corrected, }\end{array}$ \\
\hline
\end{tabular}




\begin{tabular}{|c|c|c|c|c|}
\hline $\begin{array}{l}\text { Requirement } \\
\text { Category }\end{array}$ & $\begin{array}{l}\text { Requirement } \\
\text { Reference }\end{array}$ & IECC 2009 & ES2.5 & Comments \\
\hline & & & $\begin{array}{l}2.5 \text {; therefore, up to } 25 \% \text { of the slab edge may be } \\
\text { uninsulated in } 2009 \text { IECC Climate Zones } 4 \text { and } 5 \text {. }\end{array}$ & $\begin{array}{l}\text { whether the item is builder or rater approved, or } \\
\text { whether the item is not applicable to the home). } \\
\text { Homes shall pass all requirements of 'Section } 3 \text { : } \\
\text { Fully-Aligned Air Barriers' and 'Section 5: Air } \\
\text { Sealing' to qualify. Noncompliance with items in } \\
\text { other sections of this checklist shall not prevent } \\
\text { homes from earning the label. } \\
\text { Also note: The allowance for } 25 \% \text { of the slab } \\
\text { edge to be uninsulated with not comply with the } \\
\text { prescriptive requirements of the code as there is } \\
\text { no allowance for the installation of partial } \\
\text { insulation. }\end{array}$ \\
\hline Prescriptive & $\begin{array}{l}\text { 402.2 Specific } \\
\text { insulation } \\
\text { requirements. } \\
\text { 402.2.5 Steel-frame } \\
\text { ceilings, walls, and } \\
\text { floors. }\end{array}$ & $\begin{array}{l}\text { Steel-frame ceilings, walls and floors } \\
\text { shall meet the insulation requirements of } \\
\text { Table } 402.2 .5 \text { or shall meet the U-factor } \\
\text { requirements in Table } 402.1 .3 \text {. The } \\
\text { calculation of the U-factor for a steel- } \\
\text { frame envelope assembly shall use a } \\
\text { series-parallel path calculation method. } \\
\text { Exception: In Climate Zones } 1 \text { and } 2 \text {, the } \\
\text { continuous insulation requirements in } \\
\text { Table } 402.2 .5 \text { shall be permitted to be } \\
\text { reduced to R-3 for steel frame wall } \\
\text { assemblies with studs spaced at } 24 \text { inches } \\
(610 \mathrm{~mm}) \text { on center. }\end{array}$ & $\begin{array}{l}\text { (Recommended) Thermal Enclosure System } \\
\text { Rater Checklist } \\
2.0 \text { Quality Installed Insulation. } \\
\text { 2.1 Ceiling, wall, floor, and slab insulation levels } \\
\text { shall meet or exceed 2009 IECC levels. Insulation } \\
\text { levels in a home shall meet or exceed the component } \\
\text { insulation requirements in the 2009 IECC- Table } \\
\text { 402.1.1. The following exceptions apply. A) Steel- } \\
\text { frame ceilings, walls, and floors shall meet the } \\
\text { insulation requirements of the 2009 IECC - Table } \\
\text { 402.2.5. In climate zones } 1 \text { and 2, the continuous } \\
\text { insulation requirements in this table shall be } \\
\text { permitted to be reduced to R-3 for steel-frame wall } \\
\text { assemblies with studs spaced at 24" on center. This } \\
\text { exception shall not apply if the alternative } \\
\text { calculations in D) apply. D) An alternative } \\
\text { equivalent U-factor or total UA calculation may also } \\
\text { be used to demonstrate compliance, as follows: An } \\
\text { assembly with a U-factor equal or less than } \\
\text { specified in 2009 IECC Table } 402.1 .3 \text { complies. A } \\
\text { total building thermal envelope UA that is less than } \\
\text { or equal to the total UA resulting from the U-factors } \\
\text { in Table } 402.1 .3 \text { also complies. The insulation levels } \\
\text { of all non0fenestration components (i.e., ceilings, } \\
\text { walls, floors, and slabs) can be traded off using the } \\
\text { UA approach under both the Prescriptive and the } \\
\text { Performance path. ... The UA calculation shall be } \\
\text { done using a method consistent with the ASHRAE } \\
\text { Handbook of Fundamentals and shall include the } \\
\text { thermal bridging effects of framing materials. The } \\
\text { calculation for a steel-frame envelope assembly } \\
\text { shall use a series-parallel path calculation method. } \\
\text { V2.5 Program Requirements: The Version } 2 \text { slab } \\
\text { edge insulation exemption remains only for Version } \\
\text { 2.5; therefore, up to 25\% of the slab edge may be }\end{array}$ & $\begin{array}{l}\text { Optional - ENERGY STAR V2.5 requirement does } \\
\text { not meet the 2009 IECC requirement unless the } \\
\text { feature is complied with. Note V2.5 Program } \\
\text { requirements: Inspection Checklist - Thermal } \\
\text { Enclosure System. All items on this inspection } \\
\text { checklist shall be completed (i.e., the rater must } \\
\text { indicate whether each item must be corrected, } \\
\text { whether the item is builder or rater approved, or } \\
\text { whether the item is not applicable to the home). } \\
\text { Homes shall pass all requirements of 'Section } 3 \text { : } \\
\text { Fully-Aligned Air Barriers' and 'Section 5: Air } \\
\text { Sealing' to qualify. Noncompliance with items in } \\
\text { other sections of this checklist shall not prevent } \\
\text { homes from earning the label. }\end{array}$ \\
\hline
\end{tabular}




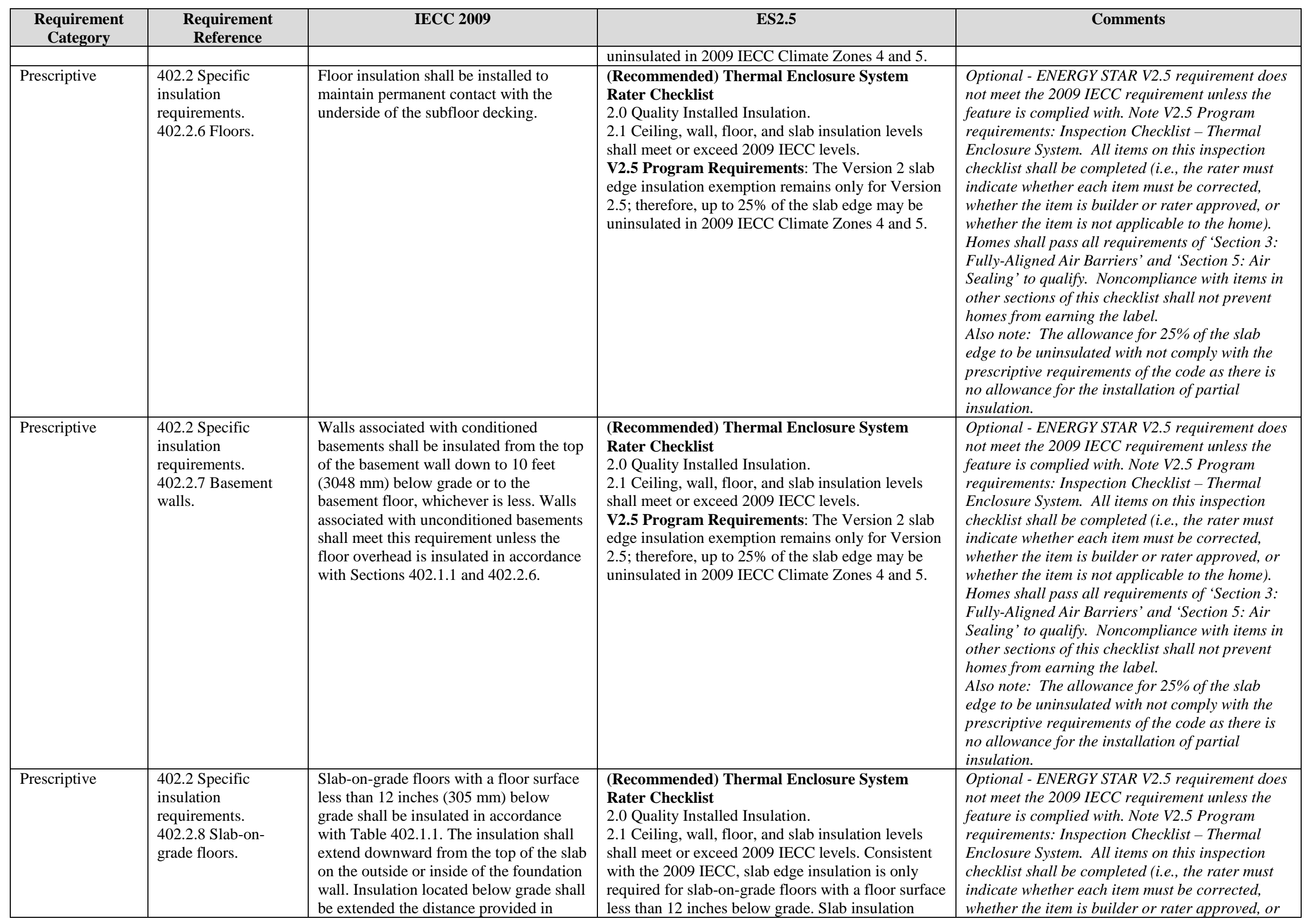




\begin{tabular}{|c|c|c|c|c|}
\hline $\begin{array}{c}\text { Requirement } \\
\text { Category }\end{array}$ & $\begin{array}{l}\text { Requirement } \\
\text { Reference }\end{array}$ & IECC 2009 & ES2.5 & Comments \\
\hline & & $\begin{array}{l}\text { Table } 402.1 .1 \text { by any combination of } \\
\text { vertical insulation, insulation extending } \\
\text { under the slab or insulation extending out } \\
\text { from the building. Insulation extending } \\
\text { away from the building shall be protected } \\
\text { by pavement or by a minimum of } 10 \\
\text { inches ( } 254 \mathrm{~mm} \text { ) of soil. The top edge of } \\
\text { the insulation installed between the } \\
\text { exterior wall and the edge of the interior } \\
\text { slab shall be permitted to be cut at a } 45- \\
\text { degree ( } 0.79 \text { rad) angle away from the } \\
\text { exterior wall. Slab-edge insulation is not } \\
\text { required in jurisdictions designated by } \\
\text { the code official as having a very heavy } \\
\text { termite infestation. }\end{array}$ & $\begin{array}{l}\text { shall extend to the top of the slab to provide a } \\
\text { complete thermal break. If the top edge of the } \\
\text { insulation is installed between the exterior wall and } \\
\text { the edge of the interior slab, it shall be permitted to } \\
\text { be cut at a 45-degree angle away from the exterior } \\
\text { wall. } \\
\text { V2.5 Program Requirements: The Version } 2 \text { slab } \\
\text { edge insulation exemption remains only for Version } \\
2.5 \text {; therefore, up to } 25 \% \text { of the slab edge may be } \\
\text { uninsulated in } 2009 \text { IECC Climate Zones } 4 \text { and } 5 \text {. }\end{array}$ & $\begin{array}{l}\text { whether the item is not applicable to the home). } \\
\text { Homes shall pass all requirements of 'Section 3: } \\
\text { Fully-Aligned Air Barriers' and 'Section 5: Air } \\
\text { Sealing' to qualify. Noncompliance with items in } \\
\text { other sections of this checklist shall not prevent } \\
\text { homes from earning the label. } \\
\text { Also note: The allowance for 25\% of the slab } \\
\text { edge to be uninsulated with not comply with the } \\
\text { prescriptive requirements of the code as there is } \\
\text { no allowance for the installation of partial } \\
\text { insulation. }\end{array}$ \\
\hline Prescriptive & $\begin{array}{l}\text { 402.2 Specific } \\
\text { insulation } \\
\text { requirements. } \\
\text { 402.2.9 Crawl space } \\
\text { walls. }\end{array}$ & $\begin{array}{l}\text { As an alternative to insulating floors over } \\
\text { crawl spaces, crawl space walls shall be } \\
\text { permitted to be insulated when the crawl } \\
\text { space is not vented to the outside. Crawl } \\
\text { space wall insulation shall be } \\
\text { permanently fastened to the wall and } \\
\text { extend downward from the floor to the } \\
\text { finished grade level and then vertically } \\
\text { and/or horizontally for at least an } \\
\text { additional } 24 \text { inches ( } 610 \text { mm). Exposed } \\
\text { earth in unvented crawl space } \\
\text { foundations shall be covered with a } \\
\text { continuous Class I vapor retarder in } \\
\text { accordance with the International } \\
\text { Building Code. All joints of the vapor } \\
\text { retarder shall overlap by } 6 \text { inches (153 } \\
\text { mm) and be sealed or taped. The edges of } \\
\text { the vapor retarder shall extend at least } 6 \\
\text { inches (153 mm) up the stem wall and } \\
\text { shall be attached to the stem wall. }\end{array}$ & $\begin{array}{l}\text { (Recommended) Thermal Enclosure System } \\
\text { Rater Checklist } \\
\text { 2.0- Quality Installed Insulation. } \\
\text { 2.1 Ceiling, wall, floor, and slab insulation levels } \\
\text { shall meet or exceed 2009 IECC levels. } \\
\text { V2.5 Program Requirements: The Version } 2 \text { slab } \\
\text { edge insulation exemption remains only for Version } \\
\text { 2.5; therefore, up to 25\% of the slab edge may be } \\
\text { uninsulated in } 2009 \text { IECC Climate Zones } 4 \text { and } 5 \text {. }\end{array}$ & $\begin{array}{l}\text { Optional - ENERGY STAR V2.5 requirement does } \\
\text { not meet the } 2009 \text { IECC requirement unless the } \\
\text { feature is complied with. Note V2.5 Program } \\
\text { requirements: Inspection Checklist - Thermal } \\
\text { Enclosure System. All items on this inspection } \\
\text { checklist shall be completed (i.e., the rater must } \\
\text { indicate whether each item must be corrected, } \\
\text { whether the item is builder or rater approved, or } \\
\text { whether the item is not applicable to the home). } \\
\text { Homes shall pass all requirements of 'Section 3: } \\
\text { Fully-Aligned Air Barriers' and 'Section 5: Air } \\
\text { Sealing' to qualify. Noncompliance with items in } \\
\text { other sections of this checklist shall not prevent } \\
\text { homes from earning the label. } \\
\text { Also note: The allowance for } 25 \% \text { of the slab } \\
\text { edge to be uninsulated with not comply with the } \\
\text { prescriptive requirements of the code as there is } \\
\text { no allowance for the installation of partial } \\
\text { insulation. }\end{array}$ \\
\hline Prescriptive & $\begin{array}{l}\text { 402.2 Specific } \\
\text { insulation } \\
\text { requirements. } \\
\text { 402.2.10 Masonry } \\
\text { veneer. }\end{array}$ & $\begin{array}{l}\text { Insulation shall not be required on the } \\
\text { horizontal portion of the foundation that } \\
\text { supports a masonry veneer. }\end{array}$ & $\begin{array}{l}\text { (Recommended) Thermal Enclosure System } \\
\text { Rater Checklist } \\
\text { 2.0 Quality Installed Insulation. } \\
\text { 2.1 Ceiling, wall, floor, and slab insulation levels } \\
\text { shall meet or exceed 2009 IECC levels. } \\
\text { V2.5 Program Requirements: The Version } 2 \text { slab } \\
\text { edge insulation exemption remains only for Version } \\
\text { 2.5; therefore, up to 25\% of the slab edge may be } \\
\text { uninsulated in } 2009 \text { IECC Climate Zones } 4 \text { and } 5 \text {. }\end{array}$ & $\begin{array}{l}\text { Optional - ENERGY STAR V2.5 requirement does } \\
\text { not meet the } 2009 \text { IECC requirement unless the } \\
\text { feature is complied with. Note V2.5 Program } \\
\text { requirements: Inspection Checklist - Thermal } \\
\text { Enclosure System } \\
\text { All items on this inspection checklist shall be } \\
\text { completed (i.e., the rater must indicate whether } \\
\text { each item must be corrected, whether the item is } \\
\text { builder or rater approved, or whether the item is } \\
\text { not applicable to the home). Homes shall pass all } \\
\text { requirements of 'Section 3: Fully-Aligned Air } \\
\text { Barriers' and 'Section 5: Air Sealing' to qualify. }\end{array}$ \\
\hline
\end{tabular}




\begin{tabular}{|c|c|c|c|c|}
\hline $\begin{array}{c}\text { Requirement } \\
\text { Category }\end{array}$ & $\begin{array}{c}\text { Requirement } \\
\text { Reference }\end{array}$ & IECC 2009 & ES2.5 & Comments \\
\hline & & & & $\begin{array}{l}\text { Noncompliance with items in other sections of this } \\
\text { checklist shall not prevent homes from earning the } \\
\text { label. } \\
\text { Also note: The allowance for } 25 \% \text { of the slab } \\
\text { edge to be uninsulated with not comply with the } \\
\text { prescriptive requirements of the code as there is } \\
\text { no allowance for the installation of partial } \\
\text { insulation. }\end{array}$ \\
\hline \multirow[t]{3}{*}{ Prescriptive } & $\begin{array}{l}\text { 402.2 Specific } \\
\text { insulation } \\
\text { requirements. } \\
\text { 402.2.11 Thermally } \\
\text { isolated sunroom } \\
\text { insulation. }\end{array}$ & $\begin{array}{l}\text { The minimum ceiling insulation R-values } \\
\text { shall be R-19 in Zones } 1 \text { through } 4 \text { and } \\
\text { R-24 in Zones } 5 \text { through } 8 \text {. The minimum } \\
\text { wall R-value shall be R-13 in all zones. } \\
\text { New wall(s) separating a sunroom from } \\
\text { conditioned space shall meet the building } \\
\text { thermal envelope requirements. }\end{array}$ & $\begin{array}{l}\text { (Recommended) Thermal Enclosure System } \\
\text { Rater Checklist } \\
\text { 2.0 Quality Installed Insulation. } \\
\text { 2.1 Ceiling, wall, floor, and slab insulation levels } \\
\text { shall meet or exceed 2009 IECC levels. } \\
\text { V2.5 Program Requirements: The Version } 2 \text { slab } \\
\text { edge insulation exemption remains only for Version } \\
\text { 2.5; therefore, up to 25\% of the slab edge may be } \\
\text { uninsulated in } 2009 \text { IECC Climate Zones } 4 \text { and } 5 .\end{array}$ & $\begin{array}{l}\text { Optional - ENERGY STAR V2.5 requirement does } \\
\text { not meet the } 2009 \text { IECC requirement unless the } \\
\text { feature is complied with. Note V2.5 Program } \\
\text { requirements: Inspection Checklist - Thermal } \\
\text { Enclosure System. All items on this inspection } \\
\text { checklist shall be completed (i.e., the rater must } \\
\text { indicate whether each item must be corrected, } \\
\text { whether the item is builder or rater approved, or } \\
\text { whether the item is not applicable to the home). } \\
\text { Homes shall pass all requirements of 'Section 3: } \\
\text { Fully-Aligned Air Barriers' and 'Section 5: Air } \\
\text { Sealing' to qualify. Noncompliance with items in } \\
\text { other sections of this checklist shall not prevent } \\
\text { homes from earning the label. } \\
\text { Also note: The allowance for } 25 \% \text { of the slab } \\
\text { edge to be uninsulated with not comply with the } \\
\text { prescriptive requirements of the code as there is } \\
\text { no allowance for the installation of partial } \\
\text { insulation. }\end{array}$ \\
\hline & $\begin{array}{l}\text { 402.3 Fenestration. } \\
\text { 402.3.1 U-factor. }\end{array}$ & $\begin{array}{l}\text { An area-weighted average of fenestration } \\
\text { products shall be permitted to satisfy the } \\
\text { U-factor requirements. }\end{array}$ & $\begin{array}{l}\text { (Recommended) Thermal Enclosure System } \\
\text { Rater Checklist } \\
\text { 1.0 High-Performance Fenestration } \\
\text { 1.1 Prescriptive Path: Fenestration shall meet or } \\
\text { exceed ENERGY STAR* requirements. } \\
\text { 1.2 Performance Path: Fenestration shall meet or } \\
\text { exceed } 2009 \text { IECC requirements. } \\
\text { *ENERGY STAR Program Requirements for } \\
\text { Residential Windows, Doors, and Skylights - } \\
\text { Version 5.0 as outlined at } \\
\text { www.energystar.gov/windows. }\end{array}$ & $\begin{array}{l}\text { Optional - Energy Star V2.5 requirement does not } \\
\text { meet the } 2009 \text { IECC requirements unless the } \\
\text { feature is complied with. Note V2.5 Program } \\
\text { requirements: Inspection Checklist - Thermal } \\
\text { Enclosure System. All items on this inspection } \\
\text { checklist shall be completed (i.e., the rater must } \\
\text { indicate whether each item must be corrected, } \\
\text { whether the item is builder or rater approved, or } \\
\text { whether the item is not applicable to the home). } \\
\text { Homes shall pass all requirements of 'Section 3: } \\
\text { Fully-Aligned Air Barriers' and 'Section 5: Air } \\
\text { Sealing' to qualify. Noncompliance with items in } \\
\text { other sections of this checklist shall not prevent } \\
\text { homes from earning the label. }\end{array}$ \\
\hline & $\begin{array}{l}\text { 402.3 Fenestration. } \\
\text { 402.3.2-402.3.3. }\end{array}$ & $\begin{array}{l}\text { 402.3.2 Glazed fenestration SHGC. An } \\
\text { area-weighted average of fenestration } \\
\text { products more than } 50 \text { percent glazed } \\
\text { shall be permitted to satisfy the SHGC } \\
\text { requirements. } \\
\text { 402.3.3 Glazed fenestration exemption. }\end{array}$ & $\begin{array}{l}\text { (Recommended) Thermal Enclosure System } \\
\text { Rater Checklist } \\
\text { 1.0 High-Performance Fenestration } \\
\text { 1.1 Prescriptive Path: Fenestration shall meet or } \\
\text { exceed ENERGY STAR* requirements. } \\
\text { 1.2 Performance Path: Fenestration shall meet or }\end{array}$ & $\begin{array}{l}\text { Optional - Energy Star V2.5 requirement does not } \\
\text { meet the } 2009 \text { IECC requirements unless the } \\
\text { feature is complied with. Note V2.5 Program } \\
\text { requirements: Inspection Checklist - Thermal } \\
\text { Enclosure System. All items on this inspection } \\
\text { checklist shall be completed (i.e., the rater must }\end{array}$ \\
\hline
\end{tabular}




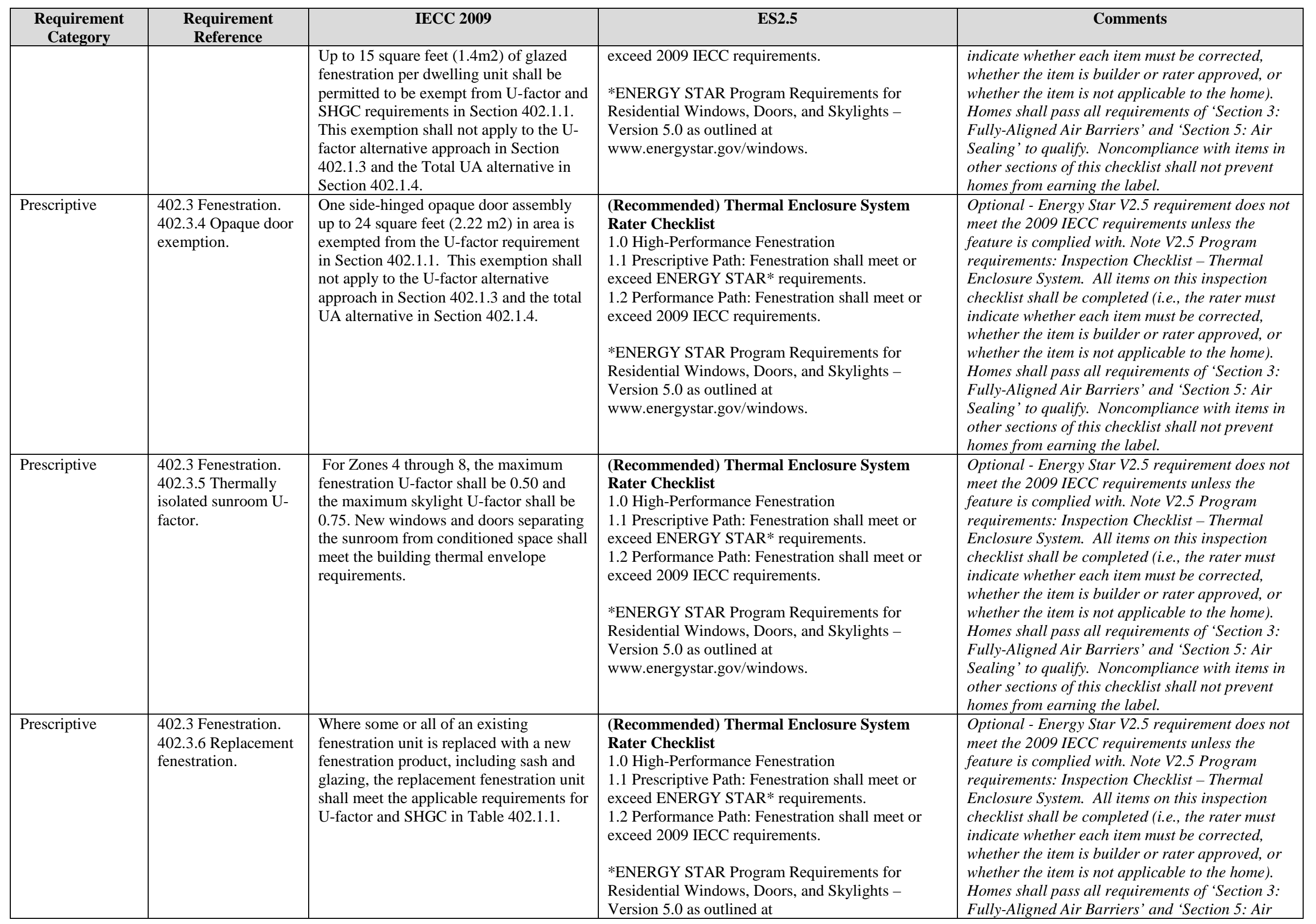




\begin{tabular}{|c|c|c|c|c|}
\hline $\begin{array}{c}\text { Requirement } \\
\text { Category }\end{array}$ & $\begin{array}{l}\text { Requirement } \\
\text { Reference }\end{array}$ & IECC 2009 & ES2.5 & Comments \\
\hline & & & www.energystar.gov/windows. & $\begin{array}{l}\text { Sealing' to qualify. Noncompliance with items in } \\
\text { other sections of this checklist shall not prevent } \\
\text { homes from earning the label. }\end{array}$ \\
\hline \multirow[t]{3}{*}{ Mandatory } & $\begin{array}{l}\text { 402.4 Air leakage. } \\
\text { 402.4.1 Building } \\
\text { thermal envelope. }\end{array}$ & $\begin{array}{l}\text { The building thermal envelope shall be } \\
\text { durably sealed to limit infiltration. The } \\
\text { sealing methods between dissimilar } \\
\text { materials shall allow for differential } \\
\text { expansion and contraction. The following } \\
\text { shall be caulked, gasketed, } \\
\text { weatherstripped or otherwise sealed with } \\
\text { an air barrier material, suitable film or } \\
\text { solid material: }\end{array}$ & - & General guidance - not a unique requirement. \\
\hline & $\begin{array}{l}\text { 402.4 Air leakage. } \\
\text { 402.4.1 Building } \\
\text { thermal envelope. (1) }\end{array}$ & $\begin{array}{l}\text { The following shall be caulked, gasketed, } \\
\text { weatherstripped or otherwise sealed with } \\
\text { an air barrier material, suitable film or } \\
\text { solid material: } \\
\text { 1. All joints, seams and penetrations. }\end{array}$ & $\begin{array}{l}\text { (Mandatory) Thermal Enclosure System Rater } \\
\text { Checklist } \\
\text { 5.0 Air Sealing } \\
\text { 5.1 Penetrations to unconditioned space fully sealed } \\
\text { with solid blocking or flashing as needed and gaps } \\
\text { sealed with caulk or foam. } \\
\text { 5.2 Cracks in the building envelope fully sealed } \\
\text { 5.3 Other openings }\end{array}$ & $\begin{array}{l}\text { Mandatory - ENERGY STAR V2.5 requirement } \\
\text { exceeds the } 2009 \text { IECC requirement. }\end{array}$ \\
\hline & $\begin{array}{l}\text { 402.4 Air leakage. } \\
\text { 402.4.1 Building } \\
\text { thermal envelope. (2) }\end{array}$ & $\begin{array}{l}\text { The following shall be caulked, gasketed, } \\
\text { weatherstripped or otherwise sealed with } \\
\text { an air barrier material, suitable film or } \\
\text { solid material: } \\
\text { 2. Site-built windows, doors and } \\
\text { skylights. }\end{array}$ & $\begin{array}{l}\text { (Mandatory) Thermal Enclosure System Rater } \\
\text { Checklist } \\
\text { 5.0 Air Sealing } \\
\text { 5.2 Cracks in the building envelope fully sealed. } \\
\text { 5.2.4 Rough Openings around windows and exterior } \\
\text { doors sealed with caulk or foam. } \\
\text { 5.3 Other Openings }\end{array}$ & $\begin{array}{l}\text { Mandatory - ENERGY STAR V2.5 requirement } \\
\text { exceeds the } 2009 \text { IECC requirement. }\end{array}$ \\
\hline Mandatory & $\begin{array}{l}\text { 402.4 Air leakage. } \\
\text { 402.4.1 Building } \\
\text { thermal envelope. (3) }\end{array}$ & $\begin{array}{l}\text { The following shall be caulked, gasketed, } \\
\text { weatherstripped or otherwise sealed with } \\
\text { an air barrier material, suitable film or } \\
\text { solid material: } \\
\text { 3. Openings between window and door } \\
\text { assemblies and their respective jambs and } \\
\text { framing. }\end{array}$ & $\begin{array}{l}\text { (Mandatory) Thermal Enclosure System Rater } \\
\text { Checklist } \\
\text { 5.0 Air Sealing } \\
\text { 5.2 Cracks in the building envelope fully sealed. } \\
\text { 5.2.4 Rough Openings around windows and exterior } \\
\text { doors sealed with caulk or foam. } \\
\text { 5.3 Other Openings }\end{array}$ & $\begin{array}{l}\text { Mandatory - ENERGY STAR V2.5 requirement } \\
\text { exceeds the } 2009 \text { IECC requirement. }\end{array}$ \\
\hline Mandatory & $\begin{array}{l}\text { 402.4 Air leakage. } \\
\text { 402.4.1 Building } \\
\text { thermal envelope. (4) }\end{array}$ & $\begin{array}{l}\text { The following shall be caulked, gasketed, } \\
\text { weatherstripped or otherwise sealed with } \\
\text { an air barrier material, suitable film or } \\
\text { solid material: } \\
\text { 4. Utility penetrations. }\end{array}$ & $\begin{array}{l}\text { (Mandatory) Thermal Enclosure System Rater } \\
\text { Checklist } \\
\text { 5.0 Air Sealing } \\
\text { 5.1 Penetrations to unconditioned space fully sealed } \\
\text { with solid blocking or flashing as needed and gaps } \\
\text { sealed with caulk or foam. }\end{array}$ & $\begin{array}{l}\text { Mandatory - ENERGY STAR V2.5 requirement } \\
\text { exceeds the } 2009 \text { IECC requirement. }\end{array}$ \\
\hline Mandatory & $\begin{array}{l}\text { 402.4 Air leakage. } \\
\text { 402.4.1 Building } \\
\text { thermal envelope. (5) }\end{array}$ & $\begin{array}{l}\text { The following shall be caulked, gasketed, } \\
\text { weatherstripped or otherwise sealed with } \\
\text { an air barrier material, suitable film or } \\
\text { solid material: } \\
\text { 5. Dropped ceilings or chases adjacent to } \\
\text { the thermal envelope. }\end{array}$ & $\begin{array}{l}\text { (Mandatory) Thermal Enclosure System Rater } \\
\text { Checklist } \\
\text { 3.0 Fully-Aligned Air Barriers } \\
\text { 3.3 Ceilings } \\
\text { 3.3.1 Dropped ceiling/soffit below unconditioned } \\
\text { attic. }\end{array}$ & $\begin{array}{l}\text { Mandatory - ENERGY STAR V2.5 requirement } \\
\text { exceeds the } 2009 \text { IECC requirement. } \\
\text { At each insulated location noted below, a } \\
\text { complete air barrier shall be provided that is fully } \\
\text { aligned with the insulation as follows: 1) At } \\
\text { interior surface of ceilings in all climate zones; }\end{array}$ \\
\hline
\end{tabular}




\begin{tabular}{|c|c|c|c|c|}
\hline $\begin{array}{c}\text { Requirement } \\
\text { Category }\end{array}$ & $\begin{array}{c}\text { Requirement } \\
\text { Reference }\end{array}$ & IECC 2009 & ES2.5 & Comments \\
\hline & & & & $\begin{array}{l}\text { also, at interior edge of attic eave in all climate } \\
\text { zones using a wind baffle that extends to the fully } \\
\text { height of the insulation. Include a baffle in every } \\
\text { bay or a tabbed baffle in each bay with a soffit } \\
\text { vent that will also prevent wind washing of } \\
\text { insulation in adjacent bays.2) At exterior surface } \\
\text { of walls in all climate zones; and also at interior } \\
\text { surface of walls for climate zones 4-8. 3) At } \\
\text { interior surface of floors in all climate zones, } \\
\text { including supports to ensure permanent contact } \\
\text { and blocking at exposed edges. }\end{array}$ \\
\hline Mandatory & $\begin{array}{l}\text { 402.4 Air leakage. } \\
\text { 402.4.1 Building } \\
\text { thermal envelope. (6) }\end{array}$ & $\begin{array}{l}\text { The following shall be caulked, gasketed, } \\
\text { weatherstripped or otherwise sealed with } \\
\text { an air barrier material, suitable film or } \\
\text { solid material: } \\
\text { 6. Knee walls. }\end{array}$ & $\begin{array}{l}\text { (Mandatory) Thermal Enclosure System Rater } \\
\text { Checklist } \\
\text { 3.0 Fully-Aligned Air Barriers } \\
\text { 3.1 Walls } \\
\text { 3.1.3 Attic knee walls / sloped attics }\end{array}$ & $\begin{array}{l}\text { Mandatory - ENERGY STAR V2.5 requirement } \\
\text { exceeds the } 2009 \text { IECC requirement. } \\
\text { At each insulated location noted below, a } \\
\text { complete air barrier shall be provided that is fully } \\
\text { aligned with the insulation as follows: 1) At } \\
\text { interior surface of ceilings in all climate zones; } \\
\text { also, at interior edge of attic eave in all climate } \\
\text { zones using a wind baffle that extends to the fully } \\
\text { height of the insulation. Include a baffle in every } \\
\text { bay or a tabbed baffle in each bay with a soffit } \\
\text { vent that will also prevent wind washing of } \\
\text { insulation in adjacent bays.2) At exterior surface } \\
\text { of walls in all climate zones; and also at interior } \\
\text { surface of walls for climate zones 4-8. 3) At } \\
\text { interior surface of floors in all climate zones, } \\
\text { including supports to ensure permanent contact } \\
\text { and blocking at exposed edges. }\end{array}$ \\
\hline Mandatory & $\begin{array}{l}\text { 402.4 Air leakage. } \\
\text { 402.4.1 Building } \\
\text { thermal envelope. (7) }\end{array}$ & $\begin{array}{l}\text { The following shall be caulked, gasketed, } \\
\text { weatherstripped or otherwise sealed with } \\
\text { an air barrier material, suitable film or } \\
\text { solid material: } \\
\text { 7. Walls and ceilings separating a garage } \\
\text { from conditioned spaces. }\end{array}$ & $\begin{array}{l}\text { (Mandatory) Thermal Enclosure System Rater } \\
\text { Checklist } \\
\text { 3.0 Fully-Aligned Air Barriers: } \\
\text { 3.1 Walls } \\
\text { 3.1.8 Garage rim / band joist adjoining conditioned } \\
\text { space. } \\
\text { 3.2 Floors } \\
\text { 3.2.1 Floor above garage } \\
\text { 3.3 Ceilings } \\
\text { 3.3.3 All other ceilings }\end{array}$ & $\begin{array}{l}\text { Mandatory - ENERGY STAR V2.5 requirement } \\
\text { exceeds the } 2009 \text { IECC requirement. } \\
\text { At each insulated location noted below, a } \\
\text { complete air barrier shall be provided that is fully } \\
\text { aligned with the insulation as follows: 1) At } \\
\text { interior surface of ceilings in all climate zones; } \\
\text { also, at interior edge of attic eave in all climate } \\
\text { zones using a wind baffle that extends to the fully } \\
\text { height of the insulation. Include a baffle in every } \\
\text { bay or a tabbed baffle in each bay with a soffit } \\
\text { vent that will also prevent wind washing of } \\
\text { insulation in adjacent bays.2) At exterior surface } \\
\text { of walls in all climate zones; and also at interior } \\
\text { surface of walls for climate zones 4-8. 3) At } \\
\text { interior surface of floors in all climate zones, } \\
\text { including supports to ensure permanent contact } \\
\text { and blocking at exposed edges. }\end{array}$ \\
\hline
\end{tabular}




\begin{tabular}{|c|c|c|c|c|}
\hline $\begin{array}{c}\text { Requirement } \\
\text { Category }\end{array}$ & $\begin{array}{c}\text { Requirement } \\
\text { Reference }\end{array}$ & IECC 2009 & ES2.5 & Comments \\
\hline Mandatory & $\begin{array}{l}\text { 402.4 Air leakage. } \\
\text { 402.4.1 Building } \\
\text { thermal envelope. (8) }\end{array}$ & $\begin{array}{l}\text { The following shall be caulked, gasketed, } \\
\text { weatherstripped or otherwise sealed with } \\
\text { an air barrier material, suitable film or } \\
\text { solid material: } \\
\text { 8. Behind tubs and showers on exterior } \\
\text { walls. }\end{array}$ & $\begin{array}{l}\text { (Mandatory) Thermal Enclosure System Rater } \\
\text { Checklist } \\
\text { 3.0 Fully-Aligned Air Barriers } \\
\text { 3.1 Walls } \\
\text { 3.1.1 Walls behind showers and tubs } \\
\text { 3.1.9 All other exterior walls }\end{array}$ & $\begin{array}{l}\text { Mandatory - ENERGY STAR V2.5 requirement } \\
\text { exceeds the } 2009 \text { IECC requirement. } \\
\text { At each insulated location noted below, a } \\
\text { complete air barrier shall be provided that is fully } \\
\text { aligned with the insulation as follows: 1) At } \\
\text { interior surface of ceilings in all climate zones; } \\
\text { also, at interior edge of attic eave in all climate } \\
\text { zones using a wind baffle that extends to the fully } \\
\text { height of the insulation. Include a baffle in every } \\
\text { bay or a tabbed baffle in each bay with a soffit } \\
\text { vent that will also prevent wind washing of } \\
\text { insulation in adjacent bays.2) At exterior surface } \\
\text { of walls in all climate zones; and also at interior } \\
\text { surface of walls for climate zones 4-8. 3) At } \\
\text { interior surface of floors in all climate zones, } \\
\text { including supports to ensure permanent contact } \\
\text { and blocking at exposed edges. }\end{array}$ \\
\hline Mandatory & $\begin{array}{l}\text { 402.4 Air leakage. } \\
\text { 402.4.1 Building } \\
\text { thermal envelope. } \\
\text { (10) }\end{array}$ & $\begin{array}{l}\text { The following shall be caulked, gasketed, } \\
\text { weatherstripped or otherwise sealed with } \\
\text { an air barrier material, suitable film or } \\
\text { solid material: } \\
\text { 10. Attic access openings. }\end{array}$ & $\begin{array}{l}\text { (Mandatory) Thermal Enclosure System Rater } \\
\text { Checklist } \\
\text { 5.0 Air Sealing } \\
\text { 5.3 Other Ceilings } \\
\text { 5.3.2 Attic access panels and drop-down stairs } \\
\text { equipped with a durable } \geq \text { R-10 insulated cover that } \\
\text { is gasketed (i.e., not caulked) to produce continuous } \\
\text { air seal when occupant is not accessing the attic. }\end{array}$ & $\begin{array}{l}\text { Mandatory - ENERGY STAR V2.5 requirement } \\
\text { exceeds the } 2009 \text { IECC requirement. }\end{array}$ \\
\hline
\end{tabular}




\begin{tabular}{|c|c|c|c|c|}
\hline $\begin{array}{c}\text { Requirement } \\
\text { Category }\end{array}$ & $\begin{array}{c}\text { Requirement } \\
\text { Reference }\end{array}$ & IECC 2009 & ES2.5 & Comments \\
\hline & & & $\begin{array}{l}\text { vent that will also prevent wind washing of } \\
\text { insulation in adjacent bays.2) At exterior surface of } \\
\text { walls in all climate zones; and also at interior } \\
\text { surface of walls for climate zones 4-8. 3) At interior } \\
\text { surface of floors in all climate zones, including } \\
\text { supports to ensure permanent contact and blocking } \\
\text { at exposed edges. } \\
\text { 3.1 Walls } \\
\text { 3.1.8 Garage rim / band joist adjoining conditioned } \\
\text { space }\end{array}$ & \\
\hline Mandatory & $\begin{array}{l}\text { 402.4 Air leakage. } \\
\text { 402.4.1 Building } \\
\text { thermal envelope. } \\
\text { (12) }\end{array}$ & $\begin{array}{l}\text { The following shall be caulked, gasketed, } \\
\text { weatherstripped or otherwise sealed with } \\
\text { an air barrier material, suitable film or } \\
\text { solid material: } \\
\text { 12. Other sources of infiltration. }\end{array}$ & $\begin{array}{l}\text { (Mandatory) Thermal Enclosure System Rater } \\
\text { Checklist } \\
\text { 5.0 Air Sealing } \\
\text { 5.1 Penetrations to unconditioned space fully sealed } \\
\text { with solid blocking or flashing as needed and gaps } \\
\text { sealed with caulk or foam. } \\
\text { 5.2 Cracks in the building envelope fully sealed } \\
\text { 5.3 Other openings }\end{array}$ & $\begin{array}{l}\text { Mandatory - ENERGY STAR V2.5 requirement } \\
\text { exceeds the } 2009 \text { IECC requirement. }\end{array}$ \\
\hline
\end{tabular}




\begin{tabular}{|c|c|c|c|c|}
\hline $\begin{array}{c}\text { Requirement } \\
\text { Category }\end{array}$ & $\begin{array}{c}\text { Requirement } \\
\text { Reference }\end{array}$ & IECC 2009 & ES2.5 & Comments \\
\hline & & $\begin{array}{l}\text { turned off; } \\
\text { 6. HVAC ducts shall not be sealed; and } \\
\text { 7. Supply and return registers shall not be } \\
\text { sealed. }\end{array}$ & & \\
\hline Mandatory & $\begin{array}{l}\text { 402.4 Air leakage. } \\
\text { 402.4.2 Air sealing } \\
\text { and insulation. } \\
\text { 402.4.2.2 Visual } \\
\text { inspection option. }\end{array}$ & $\begin{array}{l}\text { Building envelope air tightness and } \\
\text { insulation installation shall be } \\
\text { demonstrated to comply with one of the } \\
\text { following options given by Section } \\
402.4 .2 .1 \text { or } 402.4 .2 .2 \text { : } \\
\text { 402.4.2.2 Visual inspection option. } \\
\text { Building envelope tightness and } \\
\text { insulation installation shall be considered } \\
\text { acceptable when the items listed in Table } \\
402.4 .2 \text {, applicable to the method of } \\
\text { construction, are field verified. Where } \\
\text { required by the code official, an approved } \\
\text { party independent from the installer of } \\
\text { the insulation shall inspect the air barrier } \\
\text { and insulation. }\end{array}$ & $\begin{array}{l}\text { (Mandatory) HVAC System Quality Installation } \\
\text { Contractor Checklist } \\
\text { 3. Fully-Aligned Air Barriers } \\
\text { 5. Air Sealing } \\
\text { 5.3 Other Openings }\end{array}$ & $\begin{array}{l}\text { Mandatory - ENERGY STAR V2.5 requirement } \\
\text { exceeds the } 2009 \text { IECC requirement. }\end{array}$ \\
\hline Mandatory & $\begin{array}{l}\text { 402.4 Air leakage. } \\
\text { 402.4.3 Fireplaces. }\end{array}$ & $\begin{array}{l}\text { New wood-burning fireplaces shall have } \\
\text { gasketed doors and outdoor combustion } \\
\text { air. }\end{array}$ & - & Not explicitly mentioned in ENERGY STAR V2.5. \\
\hline Mandatory & $\begin{array}{l}\text { 402.4 Air leakage. } \\
\text { 402.4.4 Fenestration } \\
\text { air leakage. }\end{array}$ & $\begin{array}{l}\text { Windows, skylights and sliding glass } \\
\text { doors shall have an air infiltration rate of } \\
\text { no more than } 0.3 \mathrm{cfm} \text { per square foot ( } 1.5 \\
\mathrm{~L} / \mathrm{s} / \mathrm{m} 2) \text {, and swinging doors no more } \\
\text { than } 0.5 \mathrm{cfm} \text { per square foot }(2.6 \mathrm{~L} / \mathrm{s} / \mathrm{m} 2) \text {, } \\
\text { when tested according to NFRC } 400 \text { or } \\
\text { AAMA/WDMA/CSA } 101 / \mathrm{I} . \mathrm{S} .2 / \mathrm{A} 440 \text { by } \\
\text { an accredited, independent laboratory and } \\
\text { listed and labeled by the manufacturer. } \\
\text { Exceptions: Site-built windows, skylights } \\
\text { and doors. }\end{array}$ & $\begin{array}{l}\text { (Recommended) Thermal Enclosure System } \\
\text { Rater Checklist } \\
\text { 1.0 High-Performance Fenestration } \\
\text { 1.1 Prescriptive Path: Fenestration shall meet or } \\
\text { exceed ENERGY STAR* requirements. } \\
\text { 1.2 Performance Path: Fenestration shall meet or } \\
\text { exceed } 2009 \text { IECC requirements. } \\
\text { *ENERGY STAR Program Requirements for } \\
\text { Residential Windows, Doors, and Skylights - } \\
\text { Version 5.0 as outlined at } \\
\text { www.energystar.gov/windows. }\end{array}$ & $\begin{array}{l}\text { Optional - Energy Star V2.5 requirement does not } \\
\text { meet the } 2009 \text { IECC requirements unless the } \\
\text { feature is complied with. Note V2.5 Program } \\
\text { requirements: Inspection Checklist - Thermal } \\
\text { Enclosure System. All items on this inspection } \\
\text { checklist shall be completed (i.e., the rater must } \\
\text { indicate whether each item must be corrected, } \\
\text { whether the item is builder or rater approved, or } \\
\text { whether the item is not applicable to the home). } \\
\text { Homes shall pass all requirements of 'Section 3: } \\
\text { Fully-Aligned Air Barriers' and 'Section 5: Air } \\
\text { Sealing' to qualify. Noncompliance with items in } \\
\text { other sections of this checklist shall not prevent } \\
\text { homes from earning the label. }\end{array}$ \\
\hline Mandatory & $\begin{array}{l}\text { 402.4 Air leakage. } \\
\text { 402.4.5 Recessed } \\
\text { lighting. }\end{array}$ & $\begin{array}{l}\text { Recessed luminaires installed in the } \\
\text { building thermal envelope shall be sealed } \\
\text { to limit air leakage between conditioned } \\
\text { and unconditioned spaces. All recessed } \\
\text { luminaires shall be IC-rated and labeled } \\
\text { as meeting ASTM E } 283 \text { when tested at } \\
1.57 \mathrm{psf}(75 \mathrm{~Pa}) \mathrm{pressure} \text { differential with } \\
\text { no more than } 2.0 \mathrm{cfm}(0.944 \mathrm{~L} / \mathrm{s}) \text { of air } \\
\text { movement from the conditioned space to } \\
\text { the ceiling cavity. All recessed luminaires } \\
\text { shall be sealed with a gasket or caulk }\end{array}$ & $\begin{array}{l}\text { (Mandatory) Thermal Enclosure System Rater } \\
\text { Checklist } \\
\text { 5.0 Air Sealing } \\
\text { 5.1.5 Recessed lighting fixtures adjacent to } \\
\text { unconditioned space ICAT labeled and fully } \\
\text { gasketed. Also, if in insulated ceiling without attic } \\
\text { above, exterior surface of fixture insulated to } \geq \mathrm{R}-10 \\
\text { in climate zone } 4 \text { and higher to minimize } \\
\text { condensation potential. }\end{array}$ & $\begin{array}{l}\text { Mandatory - ENERGY STAR V2.5 requirement } \\
\text { meets the } 2009 \text { IECC requirements. }\end{array}$ \\
\hline
\end{tabular}




\begin{tabular}{|c|c|c|c|c|}
\hline $\begin{array}{c}\text { Requirement } \\
\text { Category }\end{array}$ & $\begin{array}{c}\text { Requirement } \\
\text { Reference }\end{array}$ & IECC 2009 & ES2.5 & Comments \\
\hline & & $\begin{array}{l}\text { between the housing and the interior wall } \\
\text { or ceiling covering. }\end{array}$ & & \\
\hline Mandatory & $\begin{array}{l}402.5 \text { Maximum } \\
\text { fenestration U-factor } \\
\text { and SHGC. }\end{array}$ & $\begin{array}{l}\text { The area-weighted average maximum } \\
\text { fenestration U-factor permitted using } \\
\text { trade-offs from Section } 402.1 .4 \text { or } 404 \\
\text { shall be } 0.48 \text { in Zones } 4 \text { and } 5 \text { and } 0.40 \text { in } \\
\text { Zones } 6 \text { through } 8 \text { for vertical } \\
\text { fenestration, and } 0.75 \text { in Zones } 4 \text { through } \\
8 \text { for skylights. The area-weighted } \\
\text { average maximum fenestration SHGC } \\
\text { permitted using trade-offs from Section } \\
404 \text { in Zones } 1 \text { through } 3 \text { shall be } 0.50 \text {. }\end{array}$ & $\begin{array}{l}\text { (Recommended) Thermal Enclosure System } \\
\text { Rater Checklist } \\
\text { 1.0 High-Performance Fenestration } \\
\text { 1.1 Prescriptive Path: Fenestration shall meet or } \\
\text { exceed ENERGY STAR* requirements. } \\
\text { 1.2 Performance Path: Fenestration shall meet or } \\
\text { exceed } 2009 \text { IECC requirements. } \\
\text { *ENERGY STAR Program Requirements for } \\
\text { Residential Windows, Doors, and Skylights - } \\
\text { Version 5.0 as outlined at } \\
\text { www.energystar.gov/windows. }\end{array}$ & $\begin{array}{l}\text { Optional - Energy Star V2.5 requirement does not } \\
\text { meet the } 2009 \text { IECC requirements unless the } \\
\text { feature is complied with. Note V2.5 Program } \\
\text { requirements: Inspection Checklist - Thermal } \\
\text { Enclosure System. All items on this inspection } \\
\text { checklist shall be completed (i.e., the rater must } \\
\text { indicate whether each item must be corrected, } \\
\text { whether the item is builder or rater approved, or } \\
\text { whether the item is not applicable to the home). } \\
\text { Homes shall pass all requirements of 'Section 3: } \\
\text { Fully-Aligned Air Barriers' and 'Section 5: Air } \\
\text { Sealing' to qualify. Noncompliance with items in } \\
\text { other sections of this checklist shall not prevent } \\
\text { homes from earning the label. }\end{array}$ \\
\hline Mandatory & $\begin{array}{l}\text { 403.1 Controls. } \\
403.1 .1 \\
\text { Programmable } \\
\text { thermostat. }\end{array}$ & $\begin{array}{l}\text { At least one thermostat shall be provided } \\
\text { for each separate heating and cooling } \\
\text { system. } \\
\text { 403.1.1 Programmable thermostat. Where } \\
\text { the primary heating system is a forced-air } \\
\text { furnace, at least one thermostat per } \\
\text { dwelling unit shall be capable of } \\
\text { controlling the heating and cooling } \\
\text { system on a daily schedule to maintain } \\
\text { different temperature set points at } \\
\text { different times of the day. This } \\
\text { thermostat shall include the capability to } \\
\text { set back or temporarily operate the } \\
\text { system to maintain zone temperatures } \\
\text { down to } 55^{\circ} \mathrm{F}\left(13^{\circ} \mathrm{C}\right) \text { or up to } 85^{\circ} \mathrm{F} \\
\left(29^{\circ} \mathrm{C}\right) \text {. The thermostat shall initially be } \\
\text { programmed with a heating temperature } \\
\text { set point no higher than } 70^{\circ} \mathrm{F}\left(21^{\circ} \mathrm{C} \text { ) and }\right. \\
\text { a cooling temperature set point no lower } \\
\text { than } 78^{\circ} \mathrm{F}\left(26^{\circ} \mathrm{C}\right) \text {. }\end{array}$ & $\begin{array}{l}\text { (Recommended) National Program } \\
\text { Requirements } \\
\text { Programmable thermostat shall be installed unless } \\
\text { thermostat controls a zone with electric radiant heat, } \\
\text { for which a manual thermostat is allowed }\end{array}$ & $\begin{array}{l}\text { Optional - ENERGY STAR V2.5 requirement does } \\
\text { not meet the } 2009 \text { IECC requirement unless the } \\
\text { feature is complied with. Note V2.5 Program } \\
\text { requirements: Inspection Checklist - HVAC } \\
\text { System Quality Installation for Contractors. All } \\
\text { items on this inspection checklist shall be } \\
\text { completed. However, noncompliance with items } \\
\text { will not prevent homes from earning the label. }\end{array}$ \\
\hline Mandatory & $\begin{array}{l}\text { 403.1 Controls. } \\
\text { 403.1.2 Heat pump } \\
\text { supplementary heat. }\end{array}$ & $\begin{array}{l}\text { Heat pumps having supplementary } \\
\text { electric-resistance heat shall have } \\
\text { controls that, except during defrost, } \\
\text { prevent supplemental heat operation } \\
\text { when the heat pump compressor can meet } \\
\text { the heating load. }\end{array}$ & $\begin{array}{l}\text { Recommended) HVAC System Quality } \\
\text { Installation Contractor Checklist } \\
\text { 18. For homes with heat pumps, the thermostat shall } \\
\text { have "Adaptive Recovery" technology to prevent } \\
\text { the excessive use of electric back-up heating. }\end{array}$ & $\begin{array}{l}\text { Optional - ENERGY STAR V2.5 requirement does } \\
\text { not meet the } 2009 \text { IECC requirement unless the } \\
\text { feature is complied with. Note V2.5 Program } \\
\text { requirements: Inspection Checklist - HVAC } \\
\text { System Quality Installation for Contractors. All } \\
\text { items on this inspection checklist shall be } \\
\text { completed. However, noncompliance with items } \\
\text { will not prevent homes from earning the label. }\end{array}$ \\
\hline Prescriptive & $\begin{array}{l}\text { 403.2 Ducts. } 403.2 .1 \\
\text { Insulation. }\end{array}$ & $\begin{array}{l}\text { Supply ducts in attics shall be insulated } \\
\text { to a minimum of R-8. All other ducts } \\
\text { shall be insulated to a minimum of R-6. }\end{array}$ & $\begin{array}{l}\text { (Recommended) HVAC System Quality } \\
\text { Installation Contractor Checklist } \\
\text { 3.0 Duct insulation- Applies to all heating, cooling, }\end{array}$ & $\begin{array}{l}\text { Optional - ENERGY STAR V2.5 requirement does } \\
\text { not meet the } 2009 \text { IECC requirement unless the } \\
\text { feature is complied with. Note V2.5 Program }\end{array}$ \\
\hline
\end{tabular}




\begin{tabular}{|c|c|c|c|c|}
\hline $\begin{array}{c}\text { Requirement } \\
\text { Category }\end{array}$ & $\begin{array}{l}\text { Requirement } \\
\text { Reference }\end{array}$ & IECC 2009 & ES2.5 & Comments \\
\hline & & $\begin{array}{l}\text { Exception: Ducts or portions thereof } \\
\text { located completely inside the building } \\
\text { thermal envelope. }\end{array}$ & $\begin{array}{l}\text { supply ventilation, and pressure balancing ducts. } \\
\text { 3.1 All connections to trunk ducts in unconditioned } \\
\text { space are insulated. } \\
\text { 3.2 Prescriptive Path: Supply ducts in unconditioned } \\
\text { attic have insulation } \geq \text { R-8. Performance Path: } \\
\text { Supply ducts in unconditioned space have insulation } \\
\geq \text { R- } 6 \text {. } 3.3 \text { All other supply ducts and all return } \\
\text { ducts in unconditioned space have insulation } \geq \text { R-6. }\end{array}$ & $\begin{array}{l}\text { requirements: Inspection Checklist - HVAC } \\
\text { System Quality Installation for Contractors. All } \\
\text { items on this inspection checklist shall be } \\
\text { completed. However, noncompliance with items } \\
\text { will not prevent homes from earning the label. }\end{array}$ \\
\hline Mandatory & $\begin{array}{l}403.2 \text { Ducts. } 403.2 .2 \\
\text { Sealing. }\end{array}$ & $\begin{array}{l}\text { All ducts, air handlers, filter boxes and } \\
\text { building cavities used as ducts shall be } \\
\text { sealed. Joints and seams shall comply } \\
\text { with Section M1601.4.1 of the } \\
\text { International Residential Code. }\end{array}$ & $\begin{array}{l}\text { (Mandatory) Program V2.5 Requirements: } \\
\text { Duct leakage to outdoors is maintained at the v2 } \\
\text { levels and shall not exceed the following limits: } \\
\text { o } 4 \text { CFM / } 100 \text { sq } \mathrm{ft} \text { of conditioned floor area for the } \\
\text { prescriptive path } \\
\text { o } 6 \text { CFM / } 100 \mathrm{sq} \mathrm{ft} \text { of conditioned floor area for the } \\
\text { performance path } \\
\text { No limit on total duct leakage is imposed. }\end{array}$ & $\begin{array}{l}\text { Mandatory - ENERGY STAR V2.5 requirement } \\
\text { meets the } 2009 \text { IECC requirement.. While this } \\
\text { provision does not explicitly call out the type of } \\
\text { duct sealant to use it will be almost impossible to } \\
\text { get duct work this tight w/o the use of proper } \\
\text { sealant methods. Also, this code requirement has } \\
\text { been in the states for several years so if ENERGY } \\
\text { STAR doesn't require sealing the IRC does. }\end{array}$ \\
\hline Mandatory & $\begin{array}{l}403.2 \text { Ducts. } 403.2 .2 \\
\text { Sealing. }(1-2)\end{array}$ & $\begin{array}{l}\text { Duct tightness shall be verified by either } \\
\text { of the following: } \\
1 \text {. Post-construction test: Leakage to } \\
\text { outdoors shall be less than or equal to } 8 \\
\text { cfm ( } 226.5 \mathrm{~L} / \mathrm{min} \text { ) per } 100 \mathrm{ft} 2 \text { ( } 9.29 \mathrm{~m} 2) \\
\text { of conditioned floor area or a total } \\
\text { leakage less than or equal to } 12 \mathrm{cfm} \text { ( } 12 \\
\mathrm{~L} / \mathrm{min}) \text { per } 100 \mathrm{ft} 2 \text { ( } 9.29 \mathrm{~m} 2 \text { ) of } \\
\text { conditioned floor area when tested at a } \\
\text { pressure differential of } 0.1 \text { inches w.g. } \\
\text { (25 Pa) across the entire system, } \\
\text { including the manufacturer's air handler } \\
\text { enclosure. All register boots shall be } \\
\text { taped or otherwise sealed during the test. } \\
2 \text {. Rough-in test: Total leakage shall be } \\
\text { less than or equal to } 6 \text { cfm ( } 169.9 \mathrm{~L} / \mathrm{min} \text { ) } \\
\text { per } 100 \mathrm{ft} 2 \text { ( } 9.29 \text { m2) of conditioned } \\
\text { floor area when tested at a pressure } \\
\text { differential of } 0.1 \text { inches w.g. ( } 25 \mathrm{~Pa}) \\
\text { across the roughed in system, including } \\
\text { the manufacturer's air handler enclosure. } \\
\text { All register boots shall be taped or } \\
\text { otherwise sealed during the test. If the air } \\
\text { handler is not installed at the time of the } \\
\text { test, total leakage shall be less than or } \\
\text { equal to } 4 \text { cfm ( } 113.3 \text { L/min) per } 100 \mathrm{ft} 2 \\
\text { (9.29 m2) of conditioned floor area. } \\
\text { Exceptions: Duct tightness test is not } \\
\text { required if the air handler and all ducts } \\
\text { are located within conditioned space. }\end{array}$ & $\begin{array}{l}\text { (Mandatory) Program V2.5 Requirements: } \\
\text { Duct leakage to outdoors is maintained at the v2 } \\
\text { levels and shall not exceed the following limits: } \\
\text { o } 4 \text { CFM / } 100 \text { sq ft of conditioned floor area for the } \\
\text { prescriptive path } \\
\text { o } 6 \text { CFM / } 100 \text { sq ft of conditioned floor area for the } \\
\text { performance path } \\
\text { No limit on total duct leakage is imposed. }\end{array}$ & $\begin{array}{l}\text { Mandatory - ENERGY STAR V2.5 requirement } \\
\text { meets the } 2009 \text { IECC requirement. }\end{array}$ \\
\hline Mandatory & 403.2 Ducts. 403.2 .3 & Building framing cavities shall not be & (Recommended) HVAC System Quality & Optional - ENERGY STAR V2.5 requirement does \\
\hline
\end{tabular}




\begin{tabular}{|c|c|c|c|c|}
\hline $\begin{array}{l}\text { Requirement } \\
\text { Category }\end{array}$ & $\begin{array}{c}\text { Requirement } \\
\text { Reference }\end{array}$ & IECC 2009 & ES2.5 & Comments \\
\hline & Building cavities. & used as supply ducts. & $\begin{array}{l}\text { Installation Contractor Checklist } \\
2.0 \text { Duct Quality Installation- Applies to all heating, } \\
\text { cooling, ventilation, exhaust, and pressure balancing } \\
\text { ducts. } 2.5 \text { Building cavities not used as supply or } \\
\text { return ducts unless they meet items 3.2, 3.3, 4.1, and } \\
4.2 \text { of this checklist. } \\
3.2 \text { Prescriptive Path: Supply duct in unconditioned } \\
\text { attic have insulation } \geq \text { R-8. Performance Path: } \\
\text { Supply ducts in unconditioned attic space have } \\
\text { insulation } \geq \text { R-6. } 3.3 \text { All other supply ducts and all } \\
\text { return ducts in unconditioned space have insulation } \\
\geq \text { R-6. } 4.1 \text { Total Rater- measured duct leakage } \leq 6 \\
\text { CFM25 per } 100 \text { sq. ft. of conditioned floor area. } 4.2 \\
\text { Rater-measured duct leakage to outdoors } \leq 4 \text { CFM25 } \\
\text { per } 100 \text { sq. ft. of conditioned floor area. }\end{array}$ & $\begin{array}{l}\text { not meet the } 2009 \text { IECC requirement unless the } \\
\text { feature is complied with. Note V2.5 Program } \\
\text { requirements: Inspection Checklist - HVAC } \\
\text { System Quality Installation for Contractors. All } \\
\text { items on this inspection checklist shall be } \\
\text { completed. However, noncompliance with items } \\
\text { will not prevent homes from earning the label. }\end{array}$ \\
\hline Mandatory & $\begin{array}{l}\text { 403.3 Mechanical } \\
\text { system piping } \\
\text { insulation. }\end{array}$ & $\begin{array}{l}\text { Mechanical system piping capable of } \\
\text { carrying fluids above } 105^{\circ} \mathrm{F}\left(41^{\circ} \mathrm{C}\right) \text { or } \\
\text { below } 55^{\circ} \mathrm{F}\left(13^{\circ} \mathrm{C}\right) \text { shall be insulated to a } \\
\text { minimum of } \mathrm{R}-3 \text {. }\end{array}$ & - & Not explicitly mentioned in ENERGY STAR 2.5. \\
\hline Mandatory & $\begin{array}{l}\text { 403.4 Circulating hot } \\
\text { water systems. }\end{array}$ & $\begin{array}{l}\text { All circulating service hot water piping } \\
\text { shall be insulated to at least R-2. } \\
\text { Circulating hot water systems shall } \\
\text { include an automatic or readily accessible } \\
\text { manual switch that can turn off the hot } \\
\text { water circulating pump when the system } \\
\text { is not in use. }\end{array}$ & - & Not explicitly mentioned in ENERGY STAR 2.5. \\
\hline Mandatory & $\begin{array}{l}403.5 \text { Mechanical } \\
\text { ventilation. }\end{array}$ & $\begin{array}{l}\text { Outdoor air intakes and exhausts shall } \\
\text { have automatic or gravity dampers that } \\
\text { close when the ventilation system is not } \\
\text { operating. }\end{array}$ & ( & Not explicitly mentioned in ENERGY STAR 2.5. \\
\hline Mandatory & $\begin{array}{l}\text { 403.6 Equipment } \\
\text { sizing. }\end{array}$ & $\begin{array}{l}\text { Heating and cooling equipment shall be } \\
\text { sized in accordance with Section } \\
\text { M1401.3 of the International Residential } \\
\text { Code. }\end{array}$ & $\begin{array}{l}\text { (Recommended) HVAC System Quality } \\
\text { Installation Contractor Checklist } \\
1.0 \text { Heating and cooling loads shall be calculated, } \\
\text { equipment capacity shall be selected, and duct } \\
\text { systems shall be sized according to the latest } \\
\text { editions of ACCA Manuals J, S, and D, } \\
\text { respectively, ASHRAE } 2009 \text { Handbook of } \\
\text { Fundamentals, or a substantively equivalent } \\
\text { procedure. }\end{array}$ & $\begin{array}{l}\text { Optional - ENERGY STAR V2.5 requirement does } \\
\text { not meet the } 2009 \text { IECC requirement unless the } \\
\text { feature is complied with. Note V2.5 Program } \\
\text { requirements: Inspection Checklist - HVAC } \\
\text { System Quality Installation for Contractors. All } \\
\text { items on this inspection checklist shall be } \\
\text { completed. However, noncompliance with items } \\
\text { will not prevent homes from earning the label. }\end{array}$ \\
\hline Mandatory & $\begin{array}{l}\text { 403.7 Systems } \\
\text { serving multiple } \\
\text { dwelling units. }\end{array}$ & $\begin{array}{l}\text { Systems serving multiple dwelling units } \\
\text { shall comply with Sections } 503 \text { and } 504 \\
\text { in lieu of Section } 403 \text {. }\end{array}$ & - & $\begin{array}{l}\text { Commercial requirements are outside of the scope } \\
\text { of this analysis. }\end{array}$ \\
\hline Mandatory & $\begin{array}{l}403.8 \text { Snow melt } \\
\text { system controls. }\end{array}$ & $\begin{array}{l}\text { Snow- and ice-melting systems, supplied } \\
\text { through energy service to the building, } \\
\text { shall include automatic controls capable } \\
\text { of shutting off the system when the } \\
\text { pavement temperature is above } 50^{\circ} \mathrm{F} \text {, and }\end{array}$ & - & Not explicitly mentioned in ENERGY STAR 2.5. \\
\hline
\end{tabular}




\begin{tabular}{|c|c|c|c|c|}
\hline $\begin{array}{c}\text { Requirement } \\
\text { Category }\end{array}$ & $\begin{array}{c}\text { Requirement } \\
\text { Reference }\end{array}$ & IECC 2009 & ES2.5 & Comments \\
\hline & & $\begin{array}{l}\text { no precipitation is falling and an } \\
\text { automatic or manual control that will } \\
\text { allow shutoff when the outdoor } \\
\text { temperature is above } 40^{\circ} \mathrm{F} \text {. }\end{array}$ & & \\
\hline Mandatory & $\begin{array}{l}\text { 403.9 Pools. 403.9.1 } \\
\text { Pool heaters. }\end{array}$ & $\begin{array}{l}\text { Pools shall be provided with energy- } \\
\text { conserving measures in accordance with } \\
\text { Sections } 403.9 .1 \text { through } 403.9 .3 \text {. } \\
\text { 403.9.1 Pool heaters. All pool heaters } \\
\text { shall be equipped with a readily } \\
\text { accessible on-off switch to allow shutting } \\
\text { off the heater without adjusting the } \\
\text { thermostat setting. Pool heaters fired by } \\
\text { natural gas or LPG shall not have } \\
\text { continuously burning pilot lights. }\end{array}$ & - & Not explicitly mentioned in ENERGY STAR 2.5. \\
\hline Mandatory & $\begin{array}{l}403.9 \text { Pools. } 403.9 .2 \\
\text { Time switches. }\end{array}$ & $\begin{array}{l}\text { Time switches that can automatically turn } \\
\text { off and on heaters and pumps according } \\
\text { to a preset schedule shall be installed on } \\
\text { swimming pool heaters and pumps. } \\
\text { Exceptions: } \\
\text { 1. Where public health standards require } \\
\text { 24-hour pump operation. } \\
\text { 2. Where pumps are required to operate } \\
\text { solar- and waste-heat-recovery pool } \\
\text { heating systems. }\end{array}$ & - & Not explicitly mentioned in ENERGY STAR 2.5. \\
\hline Mandatory & $\begin{array}{l}403.9 \text { Pools. } 403.9 .3 \\
\text { Pool covers. }\end{array}$ & $\begin{array}{l}\text { Heated pools shall be equipped with a } \\
\text { vapor-retardant pool cover on or at the } \\
\text { water surface. Pools heated to more than } \\
90^{\circ} \mathrm{F}\left(32^{\circ} \mathrm{C}\right) \text { shall have a pool cover with } \\
\text { a minimum insulation value of R-12. } \\
\text { Exception: Pools deriving over } 60 \\
\text { percent of the energy for heating from } \\
\text { site-recovered energy or solar energy } \\
\text { source. }\end{array}$ & - & Not explicitly mentioned in ENERGY STAR 2.5. \\
\hline Prescriptive & $\begin{array}{l}\text { 404.1 Lighting } \\
\text { equipment. }\end{array}$ & $\begin{array}{l}\text { A minimum of } 50 \text { percent of the lamps in } \\
\text { permanently installed lighting fixtures } \\
\text { shall be high-efficacy lamps. }\end{array}$ & $\begin{array}{l}\text { Prescriptive Path: Energy Star qualified CFLs or } \\
\text { pin-based lighting in } 80 \% \text { of fixtures in RESNET- } \\
\text { defined Qualifying Light Fixture Locations shall be } \\
\text { installed. (Alternate: Energy Star Advanced } \\
\text { Lighting Package). }\end{array}$ & $\begin{array}{l}\text { Optional - ENERGY STAR V2.5 requirement does } \\
\text { not meet the } 2009 \text { IECC requirement unless the } \\
\text { feature is complied with. Note V2.5 Program } \\
\text { requirements: Inspection Checklist - HVAC } \\
\text { System Quality Installation for Contractors. All } \\
\text { items on this inspection checklist shall be } \\
\text { completed. However, noncompliance with items } \\
\text { will not prevent homes from earning the label. }\end{array}$ \\
\hline Performance & $\begin{array}{l}405.2 \text { Mandatory } \\
\text { requirements. }\end{array}$ & $\begin{array}{l}\text { Compliance with this section requires } \\
\text { that the mandatory provisions identified } \\
\text { in Section } 401.2 \text { be met. All supply and } \\
\text { return ducts not completely inside the } \\
\text { building thermal envelope shall be } \\
\text { insulated to a minimum of R-6. }\end{array}$ & $\begin{array}{l}\text { (Recommended) HVAC System Quality } \\
\text { Installation Contractor Checklist } \\
\text { 3.0 Duct insulation } 3.1 \text { All connections to trunk } \\
\text { ducts in unconditioned space are insulated. } 3.3 \text { All } \\
\text { other supply ducts and all return ducts in } \\
\text { unconditioned space have insulation } \geq \text { R-6 }\end{array}$ & $\begin{array}{l}\text { Optional - ENERGY STAR V2.5 requirement does } \\
\text { not meet the } 2009 \text { IECC requirement unless the } \\
\text { feature is complied with. Note V2.5 Program } \\
\text { requirements: Inspection Checklist - HVAC } \\
\text { System Quality Installation for Contractors. All } \\
\text { items on this inspection checklist shall be }\end{array}$ \\
\hline
\end{tabular}

E.19 


\begin{tabular}{|c|c|c|c|c|}
\hline $\begin{array}{c}\text { Requirement } \\
\text { Category }\end{array}$ & $\begin{array}{c}\text { Requirement } \\
\text { Reference }\end{array}$ & IECC 2009 & ES2.5 & Comments \\
\hline & & & & $\begin{array}{l}\text { completed. However, noncompliance with items } \\
\text { will not prevent homes from earning the label. }\end{array}$ \\
\hline Performance & $\begin{array}{l}405.3 \text { Performance- } \\
\text { based compliance. }\end{array}$ & $\begin{array}{l}\text { Compliance based on simulated energy } \\
\text { performance requires that a proposed } \\
\text { residence (proposed design) be shown to } \\
\text { have an annual energy cost that is less } \\
\text { than or equal to the annual energy cost of } \\
\text { the standard reference design. Energy } \\
\text { prices shall be taken from a source } \\
\text { approved by the code official, such as the } \\
\text { Department of Energy, Energy } \\
\text { Information Administration's State } \\
\text { Energy Price and Expenditure Report. } \\
\text { Code officials shall be permitted to } \\
\text { require time-of-use pricing in energy cost } \\
\text { calculations. } \\
\text { Exception: The energy use based on } \\
\text { source energy expressed in Btu or Btu } \\
\text { per square foot of conditioned floor area } \\
\text { shall be permitted to be substituted for } \\
\text { the energy cost. The source energy } \\
\text { multiplier for electricity shall be } 3.16 \text {. } \\
\text { The source energy multiplier for fuels } \\
\text { other than electricity shall be } 1.1 \text {. }\end{array}$ & $\begin{array}{l}\text { National Program Requirements. Performance } \\
\text { Path: } \\
\text { 1.0 Determine the ENERGY STAR HERS Index } \\
\text { Target, which is the highest numerical HERS index } \\
\text { value that each rated home may achieve to earn the } \\
\text { ENERGY STAR. This target shall be specifically } \\
\text { determined for each rated home by following the } \\
\text { steps outlined in the document titled, "ENERGY } \\
\text { STAR HERS Index Target Procedure, Version } 3 \\
\text { (Rev. 02)”, available on EPA "s Web site. This } \\
\text { procedure defines how to configure the ENERGY } \\
\text { STAR Reference Design Home and calculate its } \\
\text { associated HERS index value and then how to apply } \\
\text { the appropriate Size Adjustment Factor to determine } \\
\text { the ENERGY STAR HERS Index Target. Note that } \\
\text { EPA will provide modified Mandatory } \\
\text { Requirements and ENERGY STAR Reference } \\
\text { Design specifications for states with energy codes } \\
\text { significantly more rigorous than the 2009 IECC. } \\
\text { Once published, these modified specifications shall } \\
\text { be used after a specified transition period, typically } \\
60 \text { days, to determine the ENERGY STAR HERS } \\
\text { Index Target in these states. Note that this process } \\
\text { shall be completed manually by a Rater until a } \\
\text { version of the RESNET-accredited software } \\
\text { program used by the Rater becomes available that } \\
\text { automatically configures the ENERGY STAR } \\
\text { Reference Design, calculates its associated HERS } \\
\text { index value, and then applies the appropriate Size } \\
\text { Adjustment Factor to determine the ENERGY } \\
\text { STAR HERS Index Target. Upon release of such a } \\
\text { version, Raters using that software program shall } \\
\text { have } 60 \text { days to begin all new ratings with this } \\
\text { updated version. 2. Using the same RESNET- } \\
\text { accredited Home Energy Rating software program, } \\
\text { configure the preferred set of energy measures for } \\
\text { the rated home and verify that the resulting HERS } \\
\text { Index meets or exceeds the ENERGY STAR HERS } \\
\text { Index Target, as determined in Step } 1 . \text { Note that, } \\
\text { regardless of the measures selected, Mandatory } \\
\text { Requirements for All Qualified Homes in Exhibit } 2 \\
\text { are also required. Also note that items } 1.2 \text { and } 2.1 \text { of } \\
\text { the Thermal Enclosure System Rater checklist } \\
\text { require that all insulation, windows, doors, and } \\
\text { skylights meet or exceed 2009 IECC requirements. }\end{array}$ & $\begin{array}{l}\text { Performance Path: ENERGY STAR V2.5 } \\
\text { requirement does not fully comply with the } 2009 \\
\text { IECC requirement. Note that the allowance for } \\
\text { equipment efficiency trade-offs contained in the } \\
\text { Performance Path are not allowed in the IECC } \\
2009 \text {. }\end{array}$ \\
\hline
\end{tabular}




\begin{tabular}{|c|c|c|c|c|}
\hline $\begin{array}{c}\text { Requirement } \\
\text { Category }\end{array}$ & $\begin{array}{l}\text { Requirement } \\
\text { Reference }\end{array}$ & IECC 2009 & ES2.5 & Comments \\
\hline Performance & $\begin{array}{l}\text { 405.4 } \\
\text { Documentation. } \\
\text { 405.4.1 Compliance } \\
\text { software tools. }\end{array}$ & $\begin{array}{l}\text { Documentation verifying that the } \\
\text { methods and accuracy of the compliance } \\
\text { software tools conform to the provisions } \\
\text { of this section shall be provided to the } \\
\text { code official. }\end{array}$ & - & Not explicitly mentioned in ENERGY STAR 2.5. \\
\hline Performance & $\begin{array}{l}405.4 \\
\text { Documentation. } \\
\text { 405.4.2 Compliance } \\
\text { report. }\end{array}$ & $\begin{array}{l}\text { Compliance software tools shall generate } \\
\text { a report that documents that the proposed } \\
\text { design complies with Section } 405.3 \text {. }\end{array}$ & - & Not explicitly mentioned in ENERGY STAR 2.5. \\
\hline Performance & $\begin{array}{l}405.4 \\
\text { Documentation. } \\
\text { 405.4.2 Compliance } \\
\text { report.(1) }\end{array}$ & $\begin{array}{l}\text { The compliance documentation shall } \\
\text { include the following information: } \\
\text { 1. Address or other identification of the } \\
\text { residence; }\end{array}$ & - & Not explicitly mentioned in ENERGY STAR 2.5. \\
\hline Performance & $\begin{array}{l}405.4 \\
\text { Documentation. } \\
\text { 405.4.2 Compliance } \\
\text { report.(2) }\end{array}$ & $\begin{array}{l}\text { The compliance documentation shall } \\
\text { include the following information: } \\
2 \text {. An inspection checklist documenting } \\
\text { the building component characteristics of } \\
\text { the proposed design as listed in Table } \\
405.5 .2(1) \text {. The inspection checklist shall } \\
\text { show results for both the standard } \\
\text { reference design and the proposed design, } \\
\text { and shall document all inputs entered by } \\
\text { the user necessary to reproduce the } \\
\text { results; }\end{array}$ & - & Not explicitly mentioned in ENERGY STAR 2.5. \\
\hline Performance & $\begin{array}{l}405.4 \\
\text { Documentation. } \\
\text { 405.4.2 Compliance } \\
\text { report.(3) }\end{array}$ & $\begin{array}{l}\text { The compliance documentation shall } \\
\text { include the following information: } \\
\text { 3. Name of individual completing the } \\
\text { compliance report; and }\end{array}$ & - & Not explicitly mentioned in ENERGY STAR 2.5. \\
\hline Performance & $\begin{array}{l}405.4 \\
\text { Documentation. } \\
\text { 405.4.2 Compliance } \\
\text { report.(4) }\end{array}$ & $\begin{array}{l}\text { The compliance documentation shall } \\
\text { include the following information: } \\
\text { 4. Name and version of the compliance } \\
\text { software tool. } \\
\text { Exception: Multiple orientations. When } \\
\text { an otherwise identical building model is } \\
\text { offered in multiple orientations, } \\
\text { compliance for any orientation shall be } \\
\text { permitted by documenting that the } \\
\text { building meets the performance } \\
\text { requirements in each of the four cardinal } \\
\text { (north, east, south and west) orientations. }\end{array}$ & - & Not explicitly mentioned in ENERGY STAR 2.5. \\
\hline Performance & $\begin{array}{l}405.4 \\
\text { Documentation. } \\
\text { 405.4.3 Additional } \\
\text { documentation. }\end{array}$ & $\begin{array}{l}\text { The code official shall be permitted to } \\
\text { require the following documents: } \\
\text { 1. Documentation of the building } \\
\text { component characteristics of the standard } \\
\text { reference design. } \\
\text { 2. A certification signed by the builder } \\
\text { providing the building component }\end{array}$ & - & Not explicitly mentioned in ENERGY STAR 2.5. \\
\hline
\end{tabular}




\begin{tabular}{|c|c|c|c|c|}
\hline $\begin{array}{c}\text { Requirement } \\
\text { Category }\end{array}$ & $\begin{array}{c}\text { Requirement } \\
\text { Reference }\end{array}$ & IECC 2009 & ES2.5 & Comments \\
\hline & & $\begin{array}{l}\text { characteristics of the proposed design as } \\
\text { given in Table 405.5.2(1). } \\
\text { 3. Documentation of the actual values } \\
\text { used in the software calculations for the } \\
\text { proposed design. }\end{array}$ & & \\
\hline Performance & $\begin{array}{l}405.5 \text { Calculation } \\
\text { procedure. }\end{array}$ & $\begin{array}{l}\text { 405.5.1 General. Except as specified by } \\
\text { this section, the standard reference design } \\
\text { and proposed design shall be configured } \\
\text { and analyzed using identical methods and } \\
\text { techniques. } \\
\text { 405.5.2 Residence specifications. The } \\
\text { standard reference design and proposed } \\
\text { design shall be configured and analyzed } \\
\text { as specified by Table } 405.5 .2(1) \text {. Table } \\
\text { 405.5.2(1) shall include by reference all } \\
\text { notes contained in Table 402.1.1. }\end{array}$ & - & Not explicitly mentioned in ENERGY STAR 2.5. \\
\hline Performance & $\begin{array}{l}\text { 405.6 Calculation } \\
\text { software tools. } \\
\text { 405.6.1 Minimum } \\
\text { capabilities. }\end{array}$ & $\begin{array}{l}\text { Calculation procedures used to comply } \\
\text { with this section shall be software tools } \\
\text { capable of calculating the annual energy } \\
\text { consumption of all building elements that } \\
\text { differ between the standard reference } \\
\text { design and the proposed design and shall } \\
\text { include the following capabilities: }\end{array}$ & - & Not explicitly mentioned in ENERGY STAR 2.5. \\
\hline Performance & $\begin{array}{l}\text { 405.6 Calculation } \\
\text { software tools. } \\
\text { 405.6.1 Minimum } \\
\text { capabilities.(1) }\end{array}$ & $\begin{array}{l}\text { Calculation procedures ... and shall } \\
\text { include the following capabilities: } \\
\text { 1. Computer generation of the standard } \\
\text { reference design using only the input for } \\
\text { the proposed design. The calculation } \\
\text { procedure shall not allow the user to } \\
\text { directly modify the building component } \\
\text { characteristics of the standard reference } \\
\text { design. }\end{array}$ & - & Not explicitly mentioned in ENERGY STAR 2.5. \\
\hline Performance & $\begin{array}{l}\text { 405.6 Calculation } \\
\text { software tools. } \\
\text { 405.6.1 Minimum } \\
\text { capabilities.(2) }\end{array}$ & $\begin{array}{l}\text { Calculation procedures ... and shall } \\
\text { include the following capabilities: } \\
\text { 2. Calculation of whole-building (as a } \\
\text { single zone) sizing for the heating and } \\
\text { cooling equipment in the standard } \\
\text { reference design residence in accordance } \\
\text { with Section M1401.3 of the } \\
\text { International Residential Code. }\end{array}$ & - & Not explicitly mentioned in ENERGY STAR 2.5. \\
\hline Performance & $\begin{array}{l}\text { 405.6 Calculation } \\
\text { software tools. } \\
\text { 405.6.1 Minimum } \\
\text { capabilities.(3) }\end{array}$ & $\begin{array}{l}\text { Calculation procedures ... and shall } \\
\text { include the following capabilities: } \\
\text { 3. Calculations that account for the } \\
\text { effects of indoor and outdoor } \\
\text { temperatures and part-load ratios on the } \\
\text { performance of heating, ventilating and } \\
\text { air-conditioning equipment based on }\end{array}$ & - & Not explicitly mentioned in ENERGY STAR 2.5. \\
\hline
\end{tabular}




\begin{tabular}{|c|c|c|c|c|}
\hline $\begin{array}{c}\text { Requirement } \\
\text { Category }\end{array}$ & $\begin{array}{c}\text { Requirement } \\
\text { Reference }\end{array}$ & IECC 2009 & ES2.5 & Comments \\
\hline & & climate and equipment sizing. & & \\
\hline Performance & $\begin{array}{l}\text { 405.6 Calculation } \\
\text { software tools. } \\
\text { 405.6.1 Minimum } \\
\text { capabilities.(4) }\end{array}$ & $\begin{array}{l}\text { Calculation procedures ... and shall } \\
\text { include the following capabilities: } \\
\text { 4. Printed code official inspection } \\
\text { checklist listing each of the proposed } \\
\text { design component characteristics from } \\
\text { Table 405.5.2(1) determined by the } \\
\text { analysis to provide compliance, along } \\
\text { with their respective performance ratings } \\
\text { (e.g., R-value, U-factor, SHGC, HSPF, } \\
\text { AFUE, SEER, EF, etc.). }\end{array}$ & - & Not explicitly mentioned in ENERGY STAR 2.5. \\
\hline Performance & $\begin{array}{l}\text { 405.6 Calculation } \\
\text { software tools. } \\
\text { 405.6.2 Specific } \\
\text { approval. }\end{array}$ & $\begin{array}{l}\text { Performance analysis tools meeting the } \\
\text { applicable sections of Section } 405 \text { shall } \\
\text { be permitted to be approved. Tools are } \\
\text { permitted to be approved based on } \\
\text { meeting a specified threshold for a } \\
\text { jurisdiction. The code official shall be } \\
\text { permitted to approve tools for a specified } \\
\text { application or limited scope. }\end{array}$ & - & Not explicitly mentioned in ENERGY STAR 2.5. \\
\hline Performance & $\begin{array}{l}405.6 \text { Calculation } \\
\text { software tools. } \\
405.6 .3 \text { Input values. }\end{array}$ & $\begin{array}{l}\text { When calculations require input values } \\
\text { not specified by Sections } 402,403,404 \\
\text { and } 405 \text {, those input values shall be taken } \\
\text { from an approved source. }\end{array}$ & - & Not explicitly mentioned in ENERGY STAR 2.5. \\
\hline
\end{tabular}


Appendix F

\section{ENERGY STAR Version 3.0 Mapping}




\begin{tabular}{|c|c|c|c|c|}
\hline $\begin{array}{l}\text { Requirement } \\
\text { Category }\end{array}$ & $\begin{array}{l}\text { IECC Requirement } \\
\text { Reference }\end{array}$ & IECC 2009 & ES3 & Comments \\
\hline Prescriptive & $\begin{array}{l}\text { 402.1.1 Insulation and } \\
\text { fenestration criteria. }\end{array}$ & $\begin{array}{l}\text { The building thermal envelope shall meet the } \\
\text { requirements of Table } 402.1 .1 \text { based on the } \\
\text { climate zone specified in Chapter } 3 \text {. }\end{array}$ & $\begin{array}{l}\text { (Mandatory) Thermal Enclosure System Rater } \\
\text { Checklist } \\
\text { 1.0 High-Performance Fenestration } \\
\text { 1.1 Prescriptive Path: Fenestration shall meet or } \\
\text { exceed ENERGY STAR* requirements. } \\
\text { 1.2 Performance Path: Fenestration shall meet or } \\
\text { exceed 2009 IECC requirements. } \\
\text { 2.0 Quality-Installed Insulation } \\
\text { 2.1 Ceiling, wall, floor, and slab insulation levels } \\
\text { shall meet or exceed 2009 IECC levels. } \\
\text { 2.2 All ceiling, wall, floor, and slab insulation } \\
\text { shall achieve RESNET- defined Grade I } \\
\text { installation, or alternatively, Grade II for surfaces } \\
\text { with insulated sheathing. } \\
\text { *ENERGY STAR Program Requirements for } \\
\text { Residential Windows, Doors, and Skylights - } \\
\text { Version } 5.0 \text { as outlined at } \\
\text { www.energystar.gov/windows. }\end{array}$ & $\begin{array}{l}\text { Mandatory - ENERGY STAR V3 requirement } \\
\text { meets the } 2009 \text { IECC requirement. }\end{array}$ \\
\hline Prescriptive & $\begin{array}{l}\text { 402.1.2 R-value } \\
\text { computation. }\end{array}$ & $\begin{array}{l}\text { Insulation material used in layers, such as } \\
\text { framing cavity insulation and insulating } \\
\text { sheathing, shall be summed to compute the } \\
\text { component R-value. The manufacturer's } \\
\text { settled R-value shall be used for blown } \\
\text { insulation. Computed R-values shall not } \\
\text { include an R-value for other building } \\
\text { materials or air films. }\end{array}$ & $\begin{array}{l}\text { (Mandatory) Thermal Enclosure System Rater } \\
\text { Checklist } \\
\text { 1.0 High-Performance Fenestration } \\
\text { 1.1 Prescriptive Path: Fenestration shall meet or } \\
\text { exceed ENERGY STAR* requirements. } \\
\text { 1.2 Performance Path: Fenestration shall meet or } \\
\text { exceed } 2009 \text { IECC requirements. } \\
\text { *ENERGY STAR Program Requirements for } \\
\text { Residential Windows, Doors, and Skylights - } \\
\text { Version 5.0 as outlined at } \\
\text { www.energystar.gov/windows. }\end{array}$ & $\begin{array}{l}\text { Prescriptive and Performance ENERGY STAR V3 } \\
\text { requirements meet or exceed the } 2009 \text { IECC } \\
\text { requirement. }\end{array}$ \\
\hline Prescriptive & $\begin{array}{l}\text { 402.1.3 U-factor } \\
\text { alternative. }\end{array}$ & $\begin{array}{l}\text { An assembly with a U-factor equal to or less } \\
\text { than that specified in Table } 402.1 .3 \text { shall be } \\
\text { permitted as an alternative to the R-value in } \\
\text { Table } 402.1 .1 \text {. }\end{array}$ & $\begin{array}{l}\text { (Mandatory) Program Requirements } \\
\text { 6.0 Insulation levels in a home shall meet or } \\
\text { exceed the component insulation requirements in } \\
\text { the } 2009 \text { IECC - Table } 402.1 .1 \text {. The } \\
\text { following exceptions apply: } \\
\text { a. Steel-frame ceilings, walls, and floors shall } \\
\text { meet the insulation requirements of the } 2009 \\
\text { IECC - Table } 402.2 .5 \text {. In CZ } 1 \text { and } 2 \text {, the } \\
\text { continuous insulation requirements in this table } \\
\text { shall be permitted to be reduced to R-3 for steel- } \\
\text { frame wall assemblies with studs spaced at } 24 \text { " on } \\
\text { center. This exception shall not apply if the } \\
\text { alternative calculations in d) are used; } \\
\text { b. For ceilings with attic spaces, R-30 shall satisfy }\end{array}$ & $\begin{array}{l}\text { Mandatory - ENERGY STAR V3 requirement } \\
\text { meets the } 2009 \text { IECC requirement. }\end{array}$ \\
\hline
\end{tabular}




\begin{tabular}{|c|c|c|c|c|}
\hline $\begin{array}{l}\text { Requirement } \\
\text { Category }\end{array}$ & $\begin{array}{l}\text { IECC Requirement } \\
\text { Reference }\end{array}$ & IECC 2009 & ES3 & Comments \\
\hline & & & $\begin{array}{l}\text { the requirement for R-38 and R-38 shall satisfy } \\
\text { the requirement for R- } 49 \text { wherever the full height } \\
\text { of uncompressed insulation at the lower R-value } \\
\text { extends over the wall top plate at the eaves. This } \\
\text { exemption shall not apply if the alternative } \\
\text { calculations in d) are used; } \\
\text { c. For ceilings without attic spaces, R-30 shall } \\
\text { satisfy the requirement for any required value } \\
\text { above R-30 if the design of the roof/ceiling } \\
\text { assembly does not provide sufficient space for the } \\
\text { required insulation value. This exemption shall be } \\
\text { limited to } 500 \text { square ft. or } 20 \% \text { of the total } \\
\text { insulated ceiling area, whichever is less. This } \\
\text { exemption shall not apply if the alternative } \\
\text { calculations in d) are used; } \\
\text { d. An alternative equivalent U-factor or total UA } \\
\text { calculation may also be used to demonstrate } \\
\text { compliance, as follows: } \\
\text { An assembly with a U-factor equal or less than } \\
\text { specified in } 2009 \text { IECC Table } 402.1 .3 \text { complies. }\end{array}$ & \\
\hline Prescriptive & $\begin{array}{l}\text { 402.1.4 Total UA } \\
\text { alternative. }\end{array}$ & $\begin{array}{l}\text { If the total building thermal envelope UA... is } \\
\text { less than of equal to the total UA resulting } \\
\text { from using the U-factors in Table } 402.1 .3 . . . . \text {, } \\
\text { the building shall be considered in } \\
\text { compliance with Table } 402.1 .1 \text {. The UA } \\
\text { calculation shall be done using a method } \\
\text { consistent with the ASHRAE Handbook of } \\
\text { Fundamentals and shall include the thermal } \\
\text { bridging effects of framing materials. The } \\
\text { SHGC requirements shall be met in addition } \\
\text { to the UA compliance. }\end{array}$ & $\begin{array}{l}\text { (Mandatory) Program Requirements } \\
\text { 6.0 Insulation levels in a home shall meet or } \\
\text { exceed the component insulation requirements in } \\
\text { the } 2009 \text { IECC - Table } 402.1 .1 \text {. The following } \\
\text { exceptions apply: } \\
\text { a. Steel-frame ceilings, walls, and floors shall } \\
\text { meet the insulation requirements of the } 2009 \\
\text { IECC - Table } 402.2 .5 \text {. In CZ } 1 \text { and 2, the } \\
\text { continuous insulation requirements in this table } \\
\text { shall be permitted to be reduced to R-3 for steel- } \\
\text { frame wall assemblies with studs spaced at } 24 \text { ” on } \\
\text { center. This exception shall not apply if the } \\
\text { alternative calculations in d) are used; } \\
\text { b. For ceilings with attic spaces, R-30 shall satisfy } \\
\text { the requirement for R-38 and R-38 shall satisfy } \\
\text { the requirement for R- } 49 \text { wherever the full height } \\
\text { of uncompressed insulation at the lower R-value } \\
\text { extends over the wall top plate at the eaves. This } \\
\text { exemption shall not apply if the alternative } \\
\text { calculations in d) are used; } \\
\text { c. For ceilings without attic spaces, R-30 shall } \\
\text { satisfy the requirement for any required value } \\
\text { above R-30 if the design of the roof/ceiling } \\
\text { assembly does not provide sufficient space for the } \\
\text { required insulation value. This exemption shall be } \\
\text { limited to } 500 \text { square ft. or } 20 \% \text { of the total } \\
\text { insulated ceiling area, whichever is less. This }\end{array}$ & $\begin{array}{l}\text { Mandatory ENERGY STAR V3 requirement meets } \\
\text { the } 2009 \text { IECC requirement. }\end{array}$ \\
\hline
\end{tabular}




\begin{tabular}{|c|c|c|c|c|}
\hline $\begin{array}{c}\text { Requirement } \\
\text { Category }\end{array}$ & $\begin{array}{c}\text { IECC Requirement } \\
\text { Reference }\end{array}$ & IECC 2009 & ES3 & Comments \\
\hline & & & $\begin{array}{l}\text { exemption shall not apply if the alternative } \\
\text { calculations in d) are used; } \\
\text { d. An alternative equivalent U-factor or total UA } \\
\text { calculation may also be used to demonstrate } \\
\text { compliance, as follows: An assembly with a U- } \\
\text { factor equal or less than specified in } 2009 \text { IECC } \\
\text { Table } 402.1 .3 \text { complies. }\end{array}$ & \\
\hline Prescriptive & $\begin{array}{l}\text { 402.2 Specific } \\
\text { insulation requirements. } \\
\text { 402.2.1 Ceilings with } \\
\text { attic spaces. }\end{array}$ & $\begin{array}{l}\text { When Section } 402.1 .1 \text { would require R-38 in } \\
\text { the ceiling, R-30 shall be deemed to satisfy } \\
\text { the requirement for R-38 whenever the full } \\
\text { height of uncompressed R- } 30 \text { insulation } \\
\text { extends over the wall top plate at the eaves. } \\
\text { Similarly, R-38 shall be deemed to satisfy the } \\
\text { requirements for R- } 49 \text { where ever the full } \\
\text { height of uncompressed R-38 insulation } \\
\text { extends over the top plate at the eaves. This } \\
\text { reduction shall not apply to the U-factor } \\
\text { alternative approach in Section } 402.1 .3 \text { and } \\
\text { the total UA alternative in Section } 402.1 .4 \text {. }\end{array}$ & $\begin{array}{l}\text { (Mandatory) Thermal Enclosure System Rater } \\
\text { Checklist } \\
2.0 \text { Quality Installed Insulation. } \\
2.1 \text { Ceiling, wall, floor, and slab insulation levels } \\
\text { shall meet or exceed } 2009 \text { IECC levels. For } \\
\text { ceilings with attic spaces, R-30 shall satisfy the } \\
\text { requirement for R-38 and R-38 shall satisfy the } \\
\text { requirement for R-49 wherever the full height of } \\
\text { uncompressed insulation at the lower R-value } \\
\text { extends over the wall top plate at the eaves. This } \\
\text { exemption shall not apply if the alternative } \\
\text { calculations in D) are used. D) An alternative } \\
\text { equivalent U-factor or total UA calculation may } \\
\text { also be used to demonstrate compliance, as } \\
\text { follows: An assembly with a U-factor equal or } \\
\text { less than specified in } 2009 \text { IECC Table } 402.1 .3 \\
\text { complies. A total building thermal envelope UA } \\
\text { that is less than or equal to the total UA resulting } \\
\text { from the U-factors in Table } 402.1 .3 \text { also complies. } \\
\text { The insulation levels of all non-fenestration } \\
\text { components (i.e., ceilings, walls, floors, and slabs) } \\
\text { can be traded off using the UA approach under } \\
\text { both the Prescriptive and the Performance path. } \\
\text { Note that fenestration products (i.e., windows, } \\
\text { skylights, doors) shall not be included in this } \\
\text { calculation. Also, not that while ceiling and slab } \\
\text { insulation can be included in trade-off } \\
\text { calculations, the R-value must meet or exceed the } \\
\text { minimum values listed in items } 4.1 \text { through } 4.3 \text { of } \\
\text { the checklist to provide an effective thermal } \\
\text { break, regardless of the UA tradeoffs calculated. } \\
\text { The UA calculation shall be done using a method } \\
\text { consistent with the ASHRAE Handbook of } \\
\text { Fundamentals and shall include the thermal } \\
\text { bridging effects of framing materials. The } \\
\text { calculation for a steel-frame envelope assembly } \\
\text { shall use a series-parallel path calculation method. }\end{array}$ & $\begin{array}{l}\text { Mandatory - ENERGY STAR V3 requirement } \\
\text { meets the } 2009 \text { IECC requirement. }\end{array}$ \\
\hline Prescriptive & $\begin{array}{l}\text { 402.2 Specific } \\
\text { insulation requirements. } \\
\text { 402.2.2 Ceilings }\end{array}$ & $\begin{array}{l}\text { Where Section } 402.1 .1 \text { would require } \\
\text { insulation levels above R-30 and the design } \\
\text { often roof/ceiling assemble does not allow }\end{array}$ & $\begin{array}{l}\text { (Mandatory) Thermal Enclosure System Rater } \\
\text { Checklist } \\
\text { 2.0 Quality Installed Insulation. }\end{array}$ & $\begin{array}{l}\text { Mandatory - ENERGY STAR V3 requirement } \\
\text { meets the } 2009 \text { IECC requirement. }\end{array}$ \\
\hline
\end{tabular}




\begin{tabular}{|c|c|c|c|c|}
\hline $\begin{array}{l}\text { Requirement } \\
\text { Category }\end{array}$ & $\begin{array}{c}\text { IECC Requirement } \\
\text { Reference }\end{array}$ & IECC 2009 & ES3 & Comments \\
\hline & without attic spaces. & $\begin{array}{l}\text { sufficient space for the required insulation, } \\
\text { the minimum required insulation for such } \\
\text { roof/ceiling assemblies shall be R-30. This } \\
\text { reduction of insulation from the requirements } \\
\text { of Section } 402.1 .1 \text { shall be limited to } 500 \\
\text { square feet of } 20 \text { percent of the total } \\
\text { insulated ceiling area, whichever is less. } \\
\text { This reduction shall not apply to the U-factor } \\
\text { alternative approach in Section } 402.1 .3 \text { and } \\
\text { the total UA alternative in Section } 4-2.1 .4 \text {. }\end{array}$ & $\begin{array}{l}\text { 2.1 Ceiling, wall, floor, and slab insulation levels } \\
\text { shall meet or exceed } 2009 \text { IECC levels. For } \\
\text { ceilings without attic spaces,R-30 shall satisfy the } \\
\text { requirement for any required value above R-30 if } \\
\text { the design of the roof/ceiling assembly does not } \\
\text { provide sufficient space for the required insulation } \\
\text { value. This exception shall be limited to } 500 \\
\text { square ft. or } 20 \% \text { of the total insulated ceiling } \\
\text { area, whichever is less. This exemption shall not } \\
\text { apply if the alternative calculations in D) are used. }\end{array}$ & \\
\hline Prescriptive & $\begin{array}{l}\text { 402.2 Specific } \\
\text { insulation requirements. } \\
\text { 402.2.3 Access hatches } \\
\text { and doors. }\end{array}$ & $\begin{array}{l}\text { Access doors from conditioned spaces to } \\
\text { unconditioned spaces (e.g., attics and crawl } \\
\text { spaces) shall be weatherstripped and } \\
\text { insulated to a level equivalent to the } \\
\text { insulation on the surrounding surfaces. } \\
\text { Access shall be provided to all equipment } \\
\text { that prevents damaging or compressing the } \\
\text { insulation. A wood framed or equivalent } \\
\text { baffle or retainer is required to be provided } \\
\text { when loose fill insulation is installed, the } \\
\text { purpose of which is to prevent the loose fill } \\
\text { insulation from spilling into the living space } \\
\text { when the attic access is opened, and to } \\
\text { provide a permanent means of maintaining } \\
\text { the installed R-value of the loose fill } \\
\text { insulation. }\end{array}$ & $\begin{array}{l}\text { (Mandatory) Thermal Enclosure System Rater } \\
\text { Checklist } \\
\text { 2.0 Quality Installed Insulation. } \\
\text { 2.1 Ceiling, wall, floor, and slab insulation levels } \\
\text { shall meet or exceed 2009 IECC levels. 5.0 Air } \\
\text { Sealing } \\
\text { 5.3 Other Openings } \\
\text { 5.3.2 Attic access panels and drop-down stairs } \\
\text { equipped with a durable } \geq \text { R-10 insulated cover } \\
\text { that is gasketed (i.e., not caulked) to produce } \\
\text { continuous air seal when occupant is not accessing } \\
\text { the attic. }\end{array}$ & $\begin{array}{l}\text { Mandatory - ENERGY STAR V3 requirement } \\
\text { meets the } 2009 \text { IECC requirement. }\end{array}$ \\
\hline Prescriptive & $\begin{array}{l}\text { 402.2 Specific } \\
\text { insulation requirements. } \\
\text { 402.2.4 Mass walls. }\end{array}$ & $\begin{array}{l}\text { Mass walls for the purposes of this chapter } \\
\text { shall be considered above-grade walls of } \\
\text { concrete block, concrete, insulated concrete } \\
\text { form (ICF), masonry cavity, brick (other than } \\
\text { brick veneer), earth (adobe, compressed earth } \\
\text { block, rammed earth) and solid timber/logs. }\end{array}$ & $\begin{array}{l}\text { (Mandatory) Thermal Enclosure System Rater } \\
\text { Checklist } \\
\text { 2.0 Quality Installed Insulation. } \\
\text { 2.1 Ceiling, wall, floor, and slab insulation levels } \\
\text { shall meet or exceed 2009 IECC levels. }\end{array}$ & $\begin{array}{l}\text { Mandatory - ENERGY STAR V3 requirement } \\
\text { meets the } 2009 \text { IECC requirement. }\end{array}$ \\
\hline Prescriptive & $\begin{array}{l}\text { 402.2 Specific } \\
\text { insulation requirements. } \\
402.2 .5 \text { Steel-frame } \\
\text { ceilings, walls, and } \\
\text { floors. }\end{array}$ & $\begin{array}{l}\text { Steel-frame ceilings, walls and floors shall } \\
\text { meet the insulation requirements of Table } \\
402.2 .5 \text { or shall meet the U-factor } \\
\text { requirements in Table } 402.1 .3 \text {. The } \\
\text { calculation of the U-factor for a steel-frame } \\
\text { envelope assembly shall use a series-parallel } \\
\text { path calculation method. } \\
\text { Exception: In Climate Zones } 1 \text { and } 2 \text {, the } \\
\text { continuous insulation requirements in Table } \\
402.2 .5 \text { shall be permitted to be reduced to } \\
\text { R-3 for steel frame wall assemblies with } \\
\text { studs spaced at } 24 \text { inches ( } 610 \text { mm) on } \\
\text { center. }\end{array}$ & $\begin{array}{l}\text { (Mandatory) Thermal Enclosure System Rater } \\
\text { Checklist } \\
\text { 2.0 Quality Installed Insulation. } \\
\text { 2.1 Ceiling, wall, floor, and slab insulation levels } \\
\text { shall meet or exceed } 2009 \text { IECC levels. Insulation } \\
\text { levels in a home shall meet or exceed the } \\
\text { component insulation requirements in the } 2009 \\
\text { IECC- Table } 402.1 .1 \text {. The following exceptions } \\
\text { apply. A) Steel-frame ceilings, walls, and floors } \\
\text { shall meet the insulation requirements of the } 2009 \\
\text { IECC - Table } 402.2 .5 \text {. In climate zones } 1 \text { and } 2 \text {, } \\
\text { the continuous insulation requirements in this } \\
\text { table shall be permitted to be reduced to R-3 for } \\
\text { steel-frame wall assemblies with studs spaced at } \\
24 " \text { on center. This exception shall not apply if the }\end{array}$ & $\begin{array}{l}\text { Mandatory - ENERGY STAR V3 requirement } \\
\text { meets the } 2009 \text { IECC requirement. }\end{array}$ \\
\hline
\end{tabular}




\begin{tabular}{|c|c|c|c|c|}
\hline $\begin{array}{c}\text { Requirement } \\
\text { Category }\end{array}$ & $\begin{array}{c}\text { IECC Requirement } \\
\text { Reference }\end{array}$ & IECC 2009 & ES3 & Comments \\
\hline & & & $\begin{array}{l}\text { alternative calculations in D) apply. D) An } \\
\text { alternative equivalent U-factor or total UA } \\
\text { calculation may also be used to demonstrate } \\
\text { compliance, as follows: An assembly with a U- } \\
\text { factor equal or less than specified in } 2009 \text { IECC } \\
\text { Table } 402.1 .3 \text { complies. A total building thermal } \\
\text { envelope UA that is less than or equal to the total } \\
\text { UA resulting from the U-factors in Table } 402.1 .3 \\
\text { also complies. The insulation levels of all } \\
\text { nonfenestration components (i.e., ceilings, walls, } \\
\text { floors, and slabs) can be traded off using the UA } \\
\text { approach under both the Prescriptive and the } \\
\text { Performance path. ... The UA calculation shall be } \\
\text { done using a method consistent with the } \\
\text { ASHRAE Handbook of Fundamentals and shall } \\
\text { include the thermal bridging effects of framing } \\
\text { materials. The calculation for a steel-frame } \\
\text { envelope assembly shall use a series-parallel path } \\
\text { calculation method. }\end{array}$ & \\
\hline Prescriptive & $\begin{array}{l}\text { 402.2 Specific } \\
\text { insulation requirements. } \\
\text { 402.2.6 Floors. }\end{array}$ & $\begin{array}{l}\text { Floor insulation shall be installed to maintain } \\
\text { permanent contact with the underside of the } \\
\text { subfloor decking. }\end{array}$ & $\begin{array}{l}\text { (Mandatory) Thermal Enclosure System Rater } \\
\text { Checklist } \\
\text { 2.0 Quality Installed Insulation. } \\
\text { 2.1 Ceiling, wall, floor, and slab insulation levels } \\
\text { shall meet or exceed 2009 IECC levels. }\end{array}$ & $\begin{array}{l}\text { Mandatory - ENERGY STAR V3 requirement } \\
\text { meets the } 2009 \text { IECC requirement. }\end{array}$ \\
\hline Prescriptive & $\begin{array}{l}\text { 402.2 Specific } \\
\text { insulation requirements. } \\
\text { 402.2.7 Basement walls. }\end{array}$ & $\begin{array}{l}\text { Walls associated with conditioned basements } \\
\text { shall be insulated from the top of the } \\
\text { basement wall down to } 10 \text { feet ( } 3048 \mathrm{~mm}) \\
\text { below grade or to the basement floor, } \\
\text { whichever is less. Walls associated with } \\
\text { unconditioned basements shall meet this } \\
\text { requirement unless the floor overhead is } \\
\text { insulated in accordance with Sections } \\
402.1 .1 \text { and } 402.2 .6 \text {. }\end{array}$ & $\begin{array}{l}\text { (Mandatory) Thermal Enclosure System Rater } \\
\text { Checklist } \\
\text { 2.0 Quality Installed Insulation. } \\
\text { 2.1 Ceiling, wall, floor, and slab insulation levels } \\
\text { shall meet or exceed 2009 IECC levels. }\end{array}$ & $\begin{array}{l}\text { Mandatory - ENERGY STAR V3 requirement } \\
\text { meets the } 2009 \text { IECC requirement. }\end{array}$ \\
\hline Prescriptive & $\begin{array}{l}\text { 402.2 Specific } \\
\text { insulation requirements. } \\
\text { 402.2.8 Slab-on-grade } \\
\text { floors. }\end{array}$ & $\begin{array}{l}\text { Slab-on-grade floors with a floor surface less } \\
\text { than } 12 \text { inches ( } 305 \mathrm{~mm} \text { ) below grade shall } \\
\text { be insulated in accordance with Table } \\
402.1 .1 \text {. The insulation shall extend } \\
\text { downward from the top of the slab on the } \\
\text { outside or inside of the foundation wall. } \\
\text { Insulation located below grade shall be } \\
\text { extended the distance provided in Table } \\
402.1 .1 \text { by any combination of vertical } \\
\text { insulation, insulation extending under the } \\
\text { slab or insulation extending out from the } \\
\text { building. Insulation extending away from the } \\
\text { building shall be protected by pavement or } \\
\text { by a minimum of } 10 \text { inches ( } 254 \mathrm{~mm} \text { ) of soil. }\end{array}$ & $\begin{array}{l}\text { (Mandatory) Thermal Enclosure System Rater } \\
\text { Checklist } \\
\text { 2.0 Quality Installed Insulation. } \\
\text { 2.1 Ceiling, wall, floor, and slab insulation levels } \\
\text { shall meet or exceed } 2009 \text { IECC levels. Consistent } \\
\text { with the } 2009 \text { IECC, slab edge insulation is only } \\
\text { required for slab-on-grade floors with a floor } \\
\text { surface less than } 12 \text { inches below grade. Slab } \\
\text { insulation shall extend to the top of the slab to } \\
\text { provide a complete thermal break. If the top edge } \\
\text { of the insulation is installed between the exterior } \\
\text { wall and the edge of the interior slab, it shall be } \\
\text { permitted to be cut at a 45-degree angle away } \\
\text { from the exterior wall. }\end{array}$ & $\begin{array}{l}\text { Mandatory - ENERGY STAR V3 requirement } \\
\text { meets the } 2009 \text { IECC requirement. }\end{array}$ \\
\hline
\end{tabular}




\begin{tabular}{|c|c|c|c|c|}
\hline $\begin{array}{c}\text { Requirement } \\
\text { Category }\end{array}$ & $\begin{array}{c}\text { IECC Requirement } \\
\text { Reference }\end{array}$ & IECC 2009 & ES3 & Comments \\
\hline & & $\begin{array}{l}\text { The top edge of the insulation installed } \\
\text { between the exterior wall and the edge of the } \\
\text { interior slab shall be permitted to be cut at a } \\
\text { 45-degree }(0.79 \text { rad) angle away from the } \\
\text { exterior wall. Slab-edge insulation is not } \\
\text { required in jurisdictions designated by the } \\
\text { code official as having a very heavy termite } \\
\text { infestation. }\end{array}$ & & \\
\hline Prescriptive & $\begin{array}{l}\text { 402.2 Specific } \\
\text { insulation requirements. } \\
\text { 402.2.9 Crawl space } \\
\text { walls. }\end{array}$ & $\begin{array}{l}\text { As an alternative to insulating floors over } \\
\text { crawl spaces, crawl space walls shall be } \\
\text { permitted to be insulated when the crawl } \\
\text { space is not vented to the outside. Crawl } \\
\text { space wall insulation shall be permanently } \\
\text { fastened to the wall and extend downward } \\
\text { from the floor to the finished grade level and } \\
\text { then vertically and/or horizontally for at least } \\
\text { an additional } 24 \text { inches ( } 610 \text { mm). Exposed } \\
\text { earth in unvented crawl space foundations } \\
\text { shall be covered with a continuous Class I } \\
\text { vapor retarder in accordance with the } \\
\text { International Building Code. All joints of the } \\
\text { vapor retarder shall overlap by } 6 \text { inches ( } 153 \\
\text { mm) and be sealed or taped. The edges of the } \\
\text { vapor retarder shall extend at least } 6 \text { inches } \\
\text { ( } 153 \text { mm) up the stem wall and shall be } \\
\text { attached to the stem wall. }\end{array}$ & $\begin{array}{l}\text { (Mandatory) Thermal Enclosure System Rater } \\
\text { Checklist } \\
\text { 2.0 Quality Installed Insulation. } \\
\text { 2.1 Ceiling, wall, floor, and slab insulation levels } \\
\text { shall meet or exceed } 2009 \text { IECC levels. }\end{array}$ & $\begin{array}{l}\text { Mandatory - ENERGY STAR V3 requirement } \\
\text { meets the } 2009 \text { IECC requirement. }\end{array}$ \\
\hline Prescriptive & $\begin{array}{l}\text { 402.2 Specific } \\
\text { insulation requirements. } \\
\text { 402.2.10 Masonry } \\
\text { veneer. }\end{array}$ & $\begin{array}{l}\text { Insulation shall not be required on the } \\
\text { horizontal portion of the foundation that } \\
\text { supports a masonry veneer. }\end{array}$ & $\begin{array}{l}\text { (Mandatory) Thermal Enclosure System Rater } \\
\text { Checklist } \\
\text { 2.0 Quality Installed Insulation. } \\
\text { 2.1 Ceiling, wall, floor, and slab insulation levels } \\
\text { shall meet or exceed 2009 IECC levels. }\end{array}$ & $\begin{array}{l}\text { Mandatory - ENERGY STAR V3 requirement } \\
\text { meets the } 2009 \text { IECC requirement. }\end{array}$ \\
\hline Prescriptive & $\begin{array}{l}\text { 402.2 Specific } \\
\text { insulation requirements. } \\
\text { 402.2.11 Thermally } \\
\text { isolated sunroom } \\
\text { insulation. }\end{array}$ & $\begin{array}{l}\text { The minimum ceiling insulation R-values } \\
\text { shall be R-19 in Zones } 1 \text { through } 4 \text { and R- } 24 \\
\text { in Zones } 5 \text { through } 8 \text {. The minimum wall R- } \\
\text { value shall be R-13 in all zones. New wall(s) } \\
\text { separating a sunroom from conditioned space } \\
\text { shall meet the building thermal envelope } \\
\text { requirements. }\end{array}$ & $\begin{array}{l}\text { (Mandatory) Thermal Enclosure System Rater } \\
\text { Checklist } \\
\text { 2.0 Quality Installed Insulation. } \\
\text { 2.1 Ceiling, wall, floor, and slab insulation levels } \\
\text { shall meet or exceed 2009 IECC levels. }\end{array}$ & $\begin{array}{l}\text { Mandatory - ENERGY STAR V3 requirement } \\
\text { meets the } 2009 \text { IECC requirement. }\end{array}$ \\
\hline
\end{tabular}




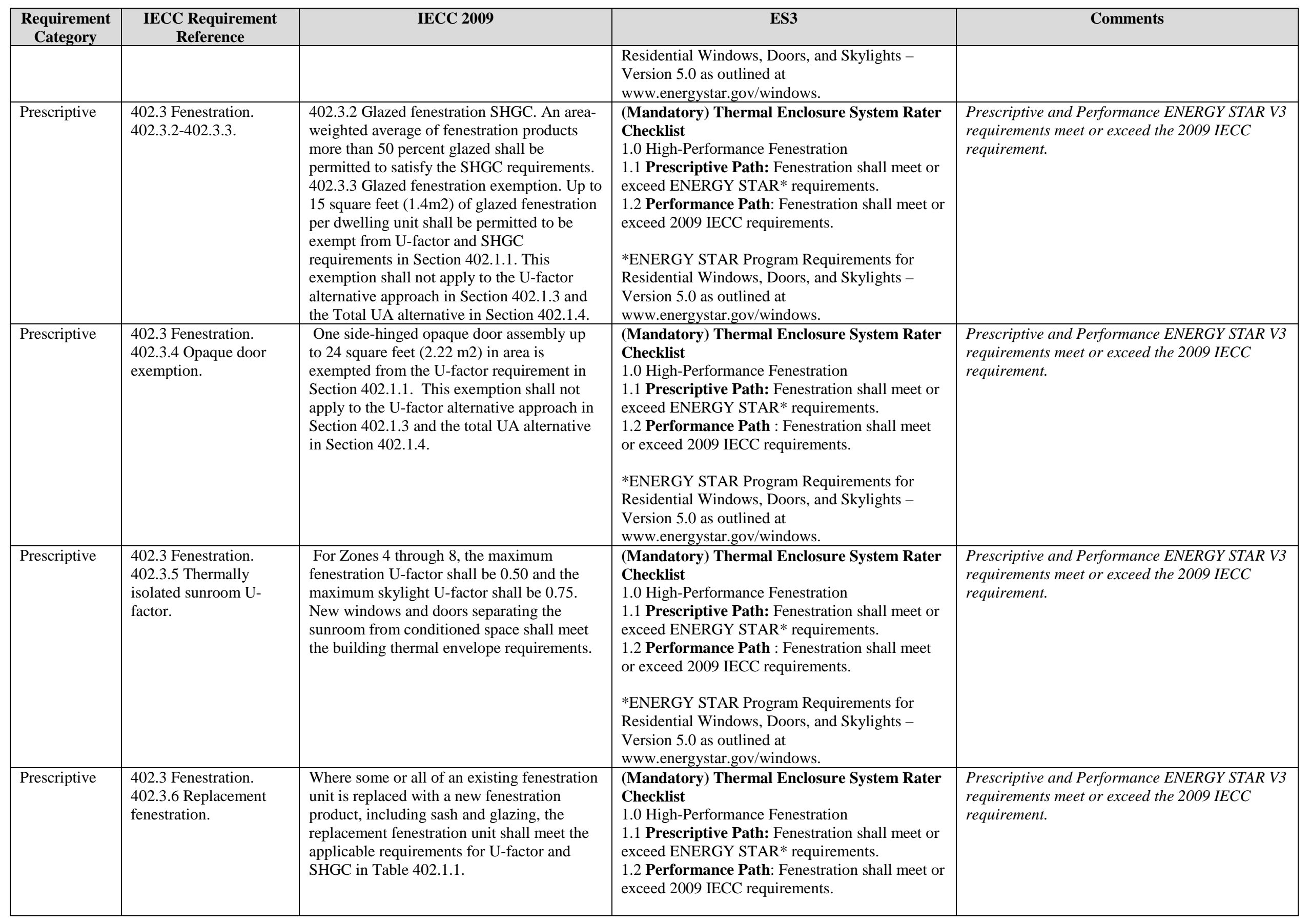




\begin{tabular}{|c|c|c|c|c|}
\hline $\begin{array}{l}\text { Requirement } \\
\text { Category }\end{array}$ & $\begin{array}{l}\text { IECC Requirement } \\
\text { Reference }\end{array}$ & IECC 2009 & ES3 & Comments \\
\hline & & & $\begin{array}{l}\text { *ENERGY STAR Program Requirements for } \\
\text { Residential Windows, Doors, and Skylights - } \\
\text { Version } 5.0 \text { as outlined at } \\
\text { www.energystar.gov/windows. }\end{array}$ & \\
\hline Mandatory & $\begin{array}{l}\text { 402.4 Air leakage. } \\
\text { 402.4.1 Building } \\
\text { thermal envelope. }\end{array}$ & $\begin{array}{l}\text { The building thermal envelope shall be } \\
\text { durably sealed to limit infiltration. The } \\
\text { sealing methods between dissimilar materials } \\
\text { shall allow for differential expansion and } \\
\text { contraction. The following shall be caulked, } \\
\text { gasketed, weatherstripped or otherwise } \\
\text { sealed with an air barrier material, suitable } \\
\text { film or solid material: }\end{array}$ & - & General guidance - not a unique requirement. \\
\hline Mandatory & $\begin{array}{l}\text { 402.4 Air leakage. } \\
\text { 402.4.1 Building } \\
\text { thermal envelope. (1) }\end{array}$ & $\begin{array}{l}\text { The following shall be caulked, gasketed, } \\
\text { weatherstripped or otherwise sealed with an } \\
\text { air barrier material, suitable film or solid } \\
\text { material: } \\
\text { 1. All joints, seams and penetrations. }\end{array}$ & $\begin{array}{l}\text { (Mandatory) Thermal Enclosure System Rater } \\
\text { Checklist } \\
\text { 5.0 Air Sealing } \\
\text { 5.1 Penetrations to unconditioned space fully } \\
\text { sealed with solid blocking or flashing as needed } \\
\text { and gaps sealed with caulk or foam. } \\
\text { 5.2 Cracks in the building envelope fully sealed } \\
\text { 5.3 Other openings }\end{array}$ & $\begin{array}{l}\text { Mandatory - ENERGY STAR V3 requirement } \\
\text { exceeds the } 2009 \text { IECC requirement. }\end{array}$ \\
\hline Mandatory & $\begin{array}{l}\text { 402.4 Air leakage. } \\
\text { 402.4.1 Building } \\
\text { thermal envelope. (2) }\end{array}$ & $\begin{array}{l}\text { The following shall be caulked, gasketed, } \\
\text { weatherstripped or otherwise sealed with an } \\
\text { air barrier material, suitable film or solid } \\
\text { material: } \\
\text { 2. Site-built windows, doors and skylights. }\end{array}$ & $\begin{array}{l}\text { (Mandatory) Thermal Enclosure System Rater } \\
\text { Checklist } \\
\text { 5.0 Air Sealing } \\
\text { 5.2 Cracks in the building envelope fully sealed. } \\
\text { 5.2.4 Rough Openings around windows and } \\
\text { exterior doors sealed with caulk or foam. } \\
\text { 5.3 Other Openings }\end{array}$ & $\begin{array}{l}\text { Mandatory - ENERGY STAR V3 requirement } \\
\text { exceeds the } 2009 \text { IECC requirement. }\end{array}$ \\
\hline Mandatory & $\begin{array}{l}\text { 402.4 Air leakage. } \\
\text { 402.4.1 Building } \\
\text { thermal envelope. (3) }\end{array}$ & $\begin{array}{l}\text { The following shall be caulked, gasketed, } \\
\text { weatherstripped or otherwise sealed with an } \\
\text { air barrier material, suitable film or solid } \\
\text { material: } \\
\text { 3. Openings between window and door } \\
\text { assemblies and their respective jambs and } \\
\text { framing. }\end{array}$ & $\begin{array}{l}\text { (Mandatory) Thermal Enclosure System Rater } \\
\text { Checklist } \\
\text { 5.0 Air Sealing } \\
\text { 5.2 Cracks in the building envelope fully sealed. } \\
\text { 5.2.4 Rough Openings around windows and } \\
\text { exterior doors sealed with caulk or foam. } \\
\text { 5.3 Other Openings }\end{array}$ & $\begin{array}{l}\text { Mandatory - ENERGY STAR V3 requirement } \\
\text { exceeds the } 2009 \text { IECC requirement. }\end{array}$ \\
\hline Mandatory & $\begin{array}{l}\text { 402.4 Air leakage. } \\
\text { 402.4.1 Building } \\
\text { thermal envelope. (4) }\end{array}$ & $\begin{array}{l}\text { The following shall be caulked, gasketed, } \\
\text { weatherstripped or otherwise sealed with an } \\
\text { air barrier material, suitable film or solid } \\
\text { material: } \\
\text { 4. Utility penetrations. }\end{array}$ & $\begin{array}{l}\text { (Mandatory) Thermal Enclosure System Rater } \\
\text { Checklist } \\
\text { 5.0 Air Sealing } \\
\text { 5.1 Penetrations to unconditioned space fully } \\
\text { sealed with solid blocking or flashing as needed } \\
\text { and gaps sealed with caulk or foam. }\end{array}$ & $\begin{array}{l}\text { Mandatory - ENERGY STAR V3 requirement } \\
\text { exceeds the } 2009 \text { IECC requirement. }\end{array}$ \\
\hline Mandatory & $\begin{array}{l}\text { 402.4 Air leakage. } \\
\text { 402.4.1 Building } \\
\text { thermal envelope. (5) }\end{array}$ & $\begin{array}{l}\text { The following shall be caulked, gasketed, } \\
\text { weatherstripped or otherwise sealed with an } \\
\text { air barrier material, suitable film or solid } \\
\text { material: } \\
\text { 5. Dropped ceilings or chases adjacent to the } \\
\text { thermal envelope. }\end{array}$ & $\begin{array}{l}\text { (Mandatory) Thermal Enclosure System Rater } \\
\text { Checklist } \\
\text { 3.0 Fully-Aligned Air Barriers } \\
\text { 3.3 Ceilings } \\
\text { 3.3.1 Dropped ceiling/soffit below unconditioned } \\
\text { attic. }\end{array}$ & $\begin{array}{l}\text { Mandatory - ENERGY STAR V3 requirement } \\
\text { exceeds the } 2009 \text { IECC requirement. } \\
\text { At each insulated location noted below, a } \\
\text { complete air barrier shall be provided that is fully } \\
\text { aligned with the insulation as follows: 1) At } \\
\text { interior surface of ceilings in all climate zones; }\end{array}$ \\
\hline
\end{tabular}




\begin{tabular}{|c|c|c|c|c|}
\hline $\begin{array}{c}\text { Requirement } \\
\text { Category }\end{array}$ & $\begin{array}{c}\text { IECC Requirement } \\
\text { Reference }\end{array}$ & IECC 2009 & ES3 & Comments \\
\hline & & & & $\begin{array}{l}\text { also, at interior edge of attic eave in all climate } \\
\text { zones using a wind baffle that extends to the fully } \\
\text { height of the insulation. Include a baffle in every } \\
\text { bay or a tabbed baffle in each bay with a soffit } \\
\text { vent that will also prevent wind washing of } \\
\text { insulation in adjacent bays.2) At exterior surface } \\
\text { of walls in all climate zones; and also at interior } \\
\text { surface of walls for climate zones 4-8. 3) At } \\
\text { interior surface of floors in all climate zones, } \\
\text { including supports to ensure permanent contact } \\
\text { and blocking at exposed edges. }\end{array}$ \\
\hline Mandatory & $\begin{array}{l}\text { 402.4 Air leakage. } \\
\text { 402.4.1 Building } \\
\text { thermal envelope. (6) }\end{array}$ & $\begin{array}{l}\text { The following shall be caulked, gasketed, } \\
\text { weatherstripped or otherwise sealed with an } \\
\text { air barrier material, suitable film or solid } \\
\text { material: } \\
\text { 6. Knee walls. }\end{array}$ & $\begin{array}{l}\text { (Mandatory) Thermal Enclosure System Rater } \\
\text { Checklist } \\
\text { 3.0 Fully-Aligned Air Barriers } \\
\text { 3.1 Walls } \\
\text { 3.1.3 Attic knee walls / sloped attics }\end{array}$ & $\begin{array}{l}\text { Mandatory - ENERGY STAR V3 requirement } \\
\text { exceeds the } 2009 \text { IECC requirement. } \\
\text { At each insulated location noted below, a } \\
\text { complete air barrier shall be provided that is fully } \\
\text { aligned with the insulation as follows: 1) At } \\
\text { interior surface of ceilings in all climate zones; } \\
\text { also, at interior edge of attic eave in all climate } \\
\text { zones using a wind baffle that extends to the fully } \\
\text { height of the insulation. Include a baffle in every } \\
\text { bay or a tabbed baffle in each bay with a soffit } \\
\text { vent that will also prevent wind washing of } \\
\text { insulation in adjacent bays.2) At exterior surface } \\
\text { of walls in all climate zones; and also at interior } \\
\text { surface of walls for climate zones 4-8. 3) At } \\
\text { interior surface of floors in all climate zones, } \\
\text { including supports to ensure permanent contact } \\
\text { and blocking at exposed edges. }\end{array}$ \\
\hline Mandatory & $\begin{array}{l}\text { 402.4 Air leakage. } \\
\text { 402.4.1 Building } \\
\text { thermal envelope. (7) }\end{array}$ & $\begin{array}{l}\text { The following shall be caulked, gasketed, } \\
\text { weatherstripped or otherwise sealed with an } \\
\text { air barrier material, suitable film or solid } \\
\text { material: } \\
\text { 7. Walls and ceilings separating a garage } \\
\text { from conditioned spaces. }\end{array}$ & $\begin{array}{l}\text { (Mandatory) Thermal Enclosure System Rater } \\
\text { Checklist } \\
\text { 3.0 Fully-Aligned Air Barriers: } \\
\text { 3.1 Walls } \\
\text { 3.1.8 Garage rim / band joist adjoining } \\
\text { conditioned space. } \\
\text { 3.2 Floors } \\
\text { 3.2.1 Floor above garage } \\
\text { 3.3 Ceilings } \\
\text { 3.3.3 All other ceilings }\end{array}$ & $\begin{array}{l}\text { Mandatory - ENERGY STAR V3 requirement } \\
\text { exceeds the } 2009 \text { IECC requirement. } \\
\text { At each insulated location noted below, a } \\
\text { complete air barrier shall be provided that is fully } \\
\text { aligned with the insulation as follows: 1) At } \\
\text { interior surface of ceilings in all climate zones; } \\
\text { also, at interior edge of attic eave in all climate } \\
\text { zones using a wind baffle that extends to the fully } \\
\text { height of the insulation. Include a baffle in every } \\
\text { bay or a tabbed baffle in each bay with a soffit } \\
\text { vent that will also prevent wind washing of } \\
\text { insulation in adjacent bays.2) At exterior surface } \\
\text { of walls in all climate zones; and also at interior } \\
\text { surface of walls for climate zones 4-8. 3) At } \\
\text { interior surface of floors in all climate zones, } \\
\text { including supports to ensure permanent contact } \\
\text { and blocking at exposed edges. }\end{array}$ \\
\hline
\end{tabular}




\begin{tabular}{|c|c|c|c|c|}
\hline $\begin{array}{l}\text { Requirement } \\
\text { Category }\end{array}$ & $\begin{array}{c}\text { IECC Requirement } \\
\text { Reference }\end{array}$ & IECC 2009 & ES3 & Comments \\
\hline Mandatory & $\begin{array}{l}\text { 402.4 Air leakage. } \\
\text { 402.4.1 Building } \\
\text { thermal envelope. (8) }\end{array}$ & $\begin{array}{l}\text { The following shall be caulked, gasketed, } \\
\text { weatherstripped or otherwise sealed with an } \\
\text { air barrier material, suitable film or solid } \\
\text { material: } \\
\text { 8. Behind tubs and showers on exterior walls. }\end{array}$ & $\begin{array}{l}\text { (Mandatory) Thermal Enclosure System Rater } \\
\text { Checklist } \\
\text { 3.0 Fully-Aligned Air Barriers } \\
\text { 3.1 Walls } \\
\text { 3.1.1 Walls behind showers and tubs } \\
\text { 3.1.9 All other exterior walls }\end{array}$ & $\begin{array}{l}\text { Mandatory - ENERGY STAR V3 requirement } \\
\text { exceed the } 2009 \text { IECC requirements. } \\
\text { At each insulated location noted below, a } \\
\text { complete air barrier shall be provided that is fully } \\
\text { aligned with the insulation as follows: 1) At } \\
\text { interior surface of ceilings in all climate zones; } \\
\text { also, at interior edge of attic eave in all climate } \\
\text { zones using a wind baffle that extends to the fully } \\
\text { height of the insulation. Include a baffle in every } \\
\text { bay or a tabbed baffle in each bay with a soffit } \\
\text { vent that will also prevent wind washing of } \\
\text { insulation in adjacent bays.2) At exterior surface } \\
\text { of walls in all climate zones; and also at interior } \\
\text { surface of walls for climate zones 4-8. 3) At } \\
\text { interior surface of floors in all climate zones, } \\
\text { including supports to ensure permanent contact } \\
\text { and blocking at exposed edges. }\end{array}$ \\
\hline Mandatory & $\begin{array}{l}\text { 402.4 Air leakage. } \\
\text { 402.4.1 Building } \\
\text { thermal envelope. (10) }\end{array}$ & $\begin{array}{l}\text { The following shall be caulked, gasketed, } \\
\text { weatherstripped or otherwise sealed with an } \\
\text { air barrier material, suitable film or solid } \\
\text { material: } \\
\text { 10. Attic access openings. }\end{array}$ & $\begin{array}{l}\text { (Mandatory) Thermal Enclosure System Rater } \\
\text { Checklist } \\
\text { 5.0 Air Sealing } \\
\text { 5.3 Other Ceilings } \\
\text { 5.3.2 Attic access panels and drop-down stairs } \\
\text { equipped with a durable } \geq \text { R-10 insulated cover } \\
\text { that is gasketed (i.e., not caulked) to produce } \\
\text { continuous air seal when occupant is not accessing } \\
\text { the attic. }\end{array}$ & $\begin{array}{l}\text { Mandatory - ENERGY STAR V3 requirement } \\
\text { exceeds the } 2009 \text { IECC requirement. }\end{array}$ \\
\hline
\end{tabular}




\begin{tabular}{|c|c|c|c|c|}
\hline $\begin{array}{c}\text { Requirement } \\
\text { Category }\end{array}$ & $\begin{array}{c}\text { IECC Requirement } \\
\text { Reference }\end{array}$ & IECC 2009 & ES3 & Comments \\
\hline & & & $\begin{array}{l}\text { insulation. Include a baffle in every bay or a } \\
\text { tabbed baffle in each bay with a soffit vent that } \\
\text { will also prevent wind washing of insulation in } \\
\text { adjacent bays.2) At exterior surface of walls in all } \\
\text { climate zones; and also at interior surface of walls } \\
\text { for climate zones 4-8. 3) At interior surface of } \\
\text { floors in all climate zones, including supports to } \\
\text { ensure permanent contact and blocking at exposed } \\
\text { edges. } \\
\text { 3.1 Walls } \\
\text { 3.1.8 Garage rim / band joist adjoining } \\
\text { conditioned space }\end{array}$ & \\
\hline Mandatory & $\begin{array}{l}\text { 402.4 Air leakage. } \\
\text { 402.4.1 Building } \\
\text { thermal envelope. (12) }\end{array}$ & $\begin{array}{l}\text { The following shall be caulked, gasketed, } \\
\text { weatherstripped or otherwise sealed with an } \\
\text { air barrier material, suitable film or solid } \\
\text { material: } \\
\text { 12. Other sources of infiltration. }\end{array}$ & $\begin{array}{l}\text { (Mandatory) Thermal Enclosure System Rater } \\
\text { Checklist } \\
\text { 5.0 Air Sealing } \\
\text { 5.1 Penetrations to unconditioned space fully } \\
\text { sealed with solid blocking or flashing as needed } \\
\text { and gaps sealed with caulk or foam. } \\
\text { 5.2 Cracks in the building envelope fully sealed } \\
\text { 5.3 Other openings }\end{array}$ & $\begin{array}{l}\text { Mandatory - ENERGY STAR V3 requirement } \\
\text { exceeds the } 2009 \text { IECC requirement. }\end{array}$ \\
\hline Mandatory & $\begin{array}{l}\text { 402.4 Air leakage. } \\
\text { 402.4.2 Air sealing and } \\
\text { insulation. 402.4.2.1 } \\
\text { Testing option. }\end{array}$ & $\begin{array}{l}\text { Building envelope air tightness and } \\
\text { insulation installation shall be demonstrated } \\
\text { to comply with one of the following options } \\
\text { given by Section } 402.4 .2 .1 \text { or } 402.4 .2 .2 \text { : } \\
402.4 .2 .1 \text { Testing option. Building envelope } \\
\text { tightness and insulation installation shall be } \\
\text { considered acceptable when tested air } \\
\text { leakage is less than seven air changes per } \\
\text { hour (ACH) when tested with a blower door } \\
\text { at a pressure of } 50 \text { pascals ( } 1 \text { psf). Testing } \\
\text { shall occur after rough in and after } \\
\text { installation of penetrations of the building } \\
\text { envelope, including penetrations for utilities, } \\
\text { plumbing, electrical, ventilation and } \\
\text { combustion appliances. } \\
\text { During testing: } \\
\text { 1. Exterior windows and doors, fireplace and } \\
\text { stove doors shall be closed, but not sealed; } \\
\text { 2. Dampers shall be closed, but not sealed, } \\
\text { including exhaust, intake, makeup air, } \\
\text { backdraft and flue dampers; } \\
\text { 3. Interior doors shall be open; } \\
\text { 4. Exterior openings for continuous } \\
\text { ventilation systems and heat recovery } \\
\text { ventilators shall be closed and sealed; } \\
\text { 5. Heating and cooling system(s) shall be } \\
\text { turned off; }\end{array}$ & $\begin{array}{l}\text { (Mandatory) HVAC System Quality } \\
\text { Installation Contractor Checklist } \\
\text { 2.10 HVAC Infiltration rates shall be less than or } \\
\text { equal to the following values: } \\
6 \text { ACH50 in CZs } 1,2 \\
5 \text { ACH50 in CZs } 3,4 \\
4 \text { ACH50 in CZs } 5,6,7 \\
3 \text { ACH50 in CZ } 8\end{array}$ & $\begin{array}{l}\text { Mandatory - ENERGY STAR V3 exceeds the } \\
\text { requirement of the } 2009 \text { IECC because the } \\
\text { recommended ACH is less than that in the IECC. } \\
\text { Note although included in the checklist for V3, } \\
\text { failure to meet the required level does not } \\
\text { prohibit the home from earning the label. }\end{array}$ \\
\hline
\end{tabular}




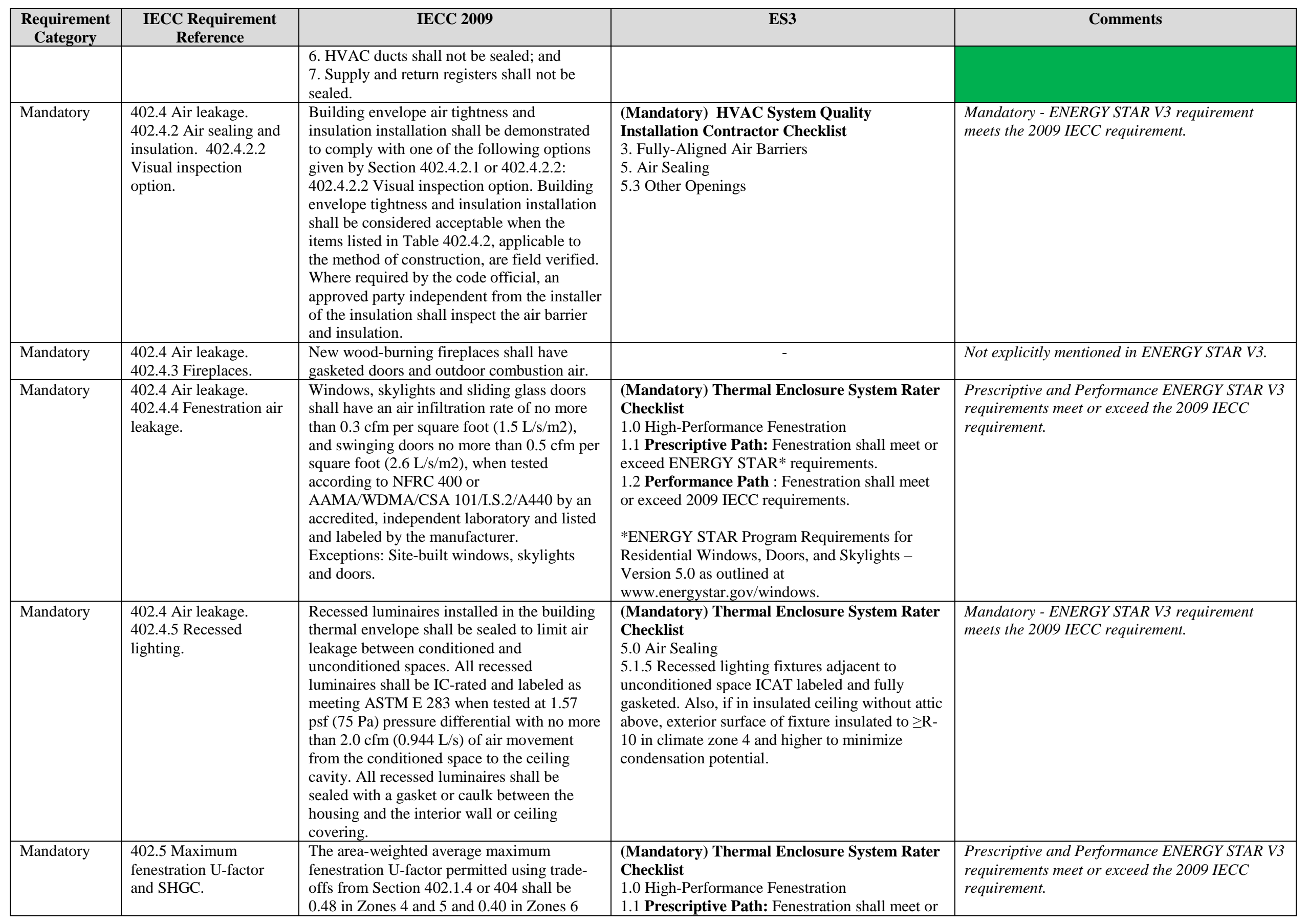




\begin{tabular}{|c|c|c|c|c|}
\hline $\begin{array}{l}\text { Requirement } \\
\text { Category }\end{array}$ & $\begin{array}{l}\text { IECC Requirement } \\
\text { Reference }\end{array}$ & IECC 2009 & ES3 & Comments \\
\hline & & $\begin{array}{l}\text { through } 8 \text { for vertical fenestration, and } 0.75 \\
\text { in Zones } 4 \text { through } 8 \text { for skylights. The area- } \\
\text { weighted average maximum fenestration } \\
\text { SHGC permitted using trade-offs from } \\
\text { Section } 404 \text { in Zones } 1 \text { through } 3 \text { shall be } \\
0.50 \text {. }\end{array}$ & $\begin{array}{l}\text { exceed ENERGY STAR* requirements. } \\
\text { 1.2 Performance Path: Fenestration shall meet or } \\
\text { exceed } 2009 \text { IECC requirements. } \\
\text { *ENERGY STAR Program Requirements for } \\
\text { Residential Windows, Doors, and Skylights - } \\
\text { Version } 5.0 \text { as outlined at } \\
\text { www.energystar.gov/windows. }\end{array}$ & \\
\hline Mandatory & $\begin{array}{l}\text { 403.1 Controls. } 403.1 .1 \\
\text { Programmable } \\
\text { thermostat. }\end{array}$ & $\begin{array}{l}\text { At least one thermostat shall be provided for } \\
\text { each separate heating and cooling system. } \\
\text { 403.1.1 Programmable thermostat. Where the } \\
\text { primary heating system is a forced-air } \\
\text { furnace, at least one thermostat per dwelling } \\
\text { unit shall be capable of controlling the } \\
\text { heating and cooling system on a daily } \\
\text { schedule to maintain different temperature } \\
\text { set points at different times of the day. This } \\
\text { thermostat shall include the capability to set } \\
\text { back or temporarily operate the system to } \\
\text { maintain zone temperatures down to } 55^{\circ} \mathrm{F} \\
\left(13^{\circ} \mathrm{C}\right) \text { or up to } 85^{\circ} \mathrm{F}\left(29^{\circ} \mathrm{C}\right) \text {. The thermostat } \\
\text { shall initially be programmed with a heating } \\
\text { temperature set point no higher than } 70^{\circ} \mathrm{F} \\
\left(21^{\circ} \mathrm{C}\right) \text { and a cooling temperature set point } \\
\text { no lower than } 78^{\circ} \mathrm{F}\left(26^{\circ} \mathrm{C}\right) \text {. }\end{array}$ & $\begin{array}{l}\text { (Mandatory) National Program Requirements } \\
\text { Programmable thermostat shall be installed unless } \\
\text { thermostat controls a zone with electric radiant } \\
\text { heat, for which a manual thermostat is allowed. }\end{array}$ & $\begin{array}{l}\text { Mandatory - ENERGY STAR V3 requirement } \\
\text { meets the } 2009 \text { IECC requirement. }\end{array}$ \\
\hline Mandatory & $\begin{array}{l}\text { 403.1 Controls. } 403.1 .2 \\
\text { Heat pump } \\
\text { supplementary heat. }\end{array}$ & $\begin{array}{l}\text { Heat pumps having supplementary electric- } \\
\text { resistance heat shall have controls that, } \\
\text { except during defrost, prevent supplemental } \\
\text { heat operation when the heat pump } \\
\text { compressor can meet the heating load. }\end{array}$ & $\begin{array}{l}\text { (Mandatory) HVAC System Quality } \\
\text { Installation Contractor Checklist } \\
\text { 18. For homes with heat pumps, the thermostat } \\
\text { shall have "Adaptive Recovery" technology to } \\
\text { prevent the excessive use of electric back-up } \\
\text { heating. }\end{array}$ & $\begin{array}{l}\text { Mandatory - ENERGY STAR V3 requirement } \\
\text { meets the } 2009 \text { IECC requirement. }\end{array}$ \\
\hline Prescriptive & $\begin{array}{l}\text { 403.2 Ducts. } 403.2 .1 \\
\text { Insulation. }\end{array}$ & $\begin{array}{l}\text { Supply ducts in attics shall be insulated to a } \\
\text { minimum of R- } 8 \text {. All other ducts shall be } \\
\text { insulated to a minimum of R-6. } \\
\text { Exception: Ducts or portions thereof located } \\
\text { completely inside the building thermal } \\
\text { envelope. }\end{array}$ & $\begin{array}{l}\text { (Mandatory) HVAC System Quality } \\
\text { Installation Contractor Checklist } \\
\text { 3.0 Duct insulation- Applies to all heating, } \\
\text { cooling, supply ventilation, and pressure } \\
\text { balancing ducts. } \\
\text { 3.1 All connections to trunk ducts in } \\
\text { unconditioned space are insulated. } \\
\text { 3.2 Prescriptive Path: Supply ducts in } \\
\text { unconditioned attic have insulation } \geq \text { R-8. } \\
\text { Performance Path: Supply ducts in unconditioned } \\
\text { space have insulation } \geq \text { R- } 6 \text {. 3.3 All other supply } \\
\text { ducts and all return ducts in unconditioned space } \\
\text { have insulation } \geq \text { R-6. }\end{array}$ & $\begin{array}{l}\text { Mandatory - ENERGY STAR V3 requirement } \\
\text { meets the } 2009 \text { IECC requirement. }\end{array}$ \\
\hline Mandatory & $\begin{array}{l}\text { 403.2 Ducts. } 403.2 .2 \\
\text { Sealing. }\end{array}$ & $\begin{array}{l}\text { All ducts, air handlers, filter boxes and } \\
\text { building cavities used as ducts shall be } \\
\text { sealed. Joints and seams shall comply with }\end{array}$ & $\begin{array}{l}\text { (Mandatory) } 14 \text {. For all homes that have less } \\
\text { than } 1,200 \text { sq ft of conditioned floor area (CFA), } \\
\text { total measured duct leakage shall be }<8 \text { CFM25 }\end{array}$ & $\begin{array}{l}\text { Mandatory - ENERGY STAR V3 requirement } \\
\text { meets the } 2009 \text { IECC requirement. }\end{array}$ \\
\hline
\end{tabular}




\begin{tabular}{|c|c|c|c|c|}
\hline $\begin{array}{l}\text { Requirement } \\
\text { Category }\end{array}$ & $\begin{array}{l}\text { IECC Requirement } \\
\text { Reference }\end{array}$ & IECC 2009 & ES3 & Comments \\
\hline & & $\begin{array}{l}\text { Section M1601.4.1 of the International } \\
\text { Residential Code. }\end{array}$ & $\begin{array}{l}\text { per } 100 \text { sq. } \mathrm{ft} \text {. of CFA and measured duct leakage } \\
\text { to outdoors shall be }<5 \text { CFM } 25 \text { per } 100 \text { sq. ft. of } \\
\text { CFA. } \\
\text { 15. If total duct leakage is }<4 \text { CFM } 25 \text { per } 100 \text { sq. } \\
\text { ft. of conditioned floor area, or }<5 \text { CFM } 25 \text { per } \\
100 \text { sq. } \mathrm{ft} \text {. of conditioned floor area for homes that } \\
\text { have less than } 1,200 \text { sq. ft. of conditioned floor } \\
\text { area, then leakage to outdoors need not be tested. }\end{array}$ & \\
\hline Mandatory & $\begin{array}{l}403.2 \text { Ducts. } 403.2 .2 \\
\text { Sealing. (1-2) }\end{array}$ & $\begin{array}{l}\text { Duct tightness shall be verified by either of } \\
\text { the following: } \\
\text { 1. Post-construction test: Leakage to } \\
\text { outdoors shall be less than or equal to } 8 \mathrm{cfm} \\
\text { ( } 226.5 \mathrm{~L} / \mathrm{min}) \text { per } 100 \mathrm{ft} 2(9.29 \mathrm{~m} 2) \text { of } \\
\text { conditioned floor area or a total leakage less } \\
\text { than or equal to } 12 \mathrm{cfm} \text { ( } 12 \mathrm{~L} / \mathrm{min}) \text { per } 100 \\
\mathrm{ft} 2 \text { ( } 9.29 \mathrm{~m} 2) \text { of conditioned floor area when } \\
\text { tested at a pressure differential of } 0.1 \text { inches } \\
\text { w.g. ( } 25 \mathrm{~Pa} \text { ) across the entire system, } \\
\text { including the manufacturer's air handler } \\
\text { enclosure. All register boots shall be taped or } \\
\text { otherwise sealed during the test. } \\
2 \text {. Rough-in test: Total leakage shall be less } \\
\text { than or equal to } 6 \text { cfm ( } 169.9 \text { L/min) per } 100 \\
\mathrm{ft} 2 \text { ( } 9.29 \mathrm{~m} 2) \text { of conditioned floor area when } \\
\text { tested at a pressure differential of } 0.1 \text { inches } \\
\text { w.g. ( } 25 \text { Pa) across the roughed in system, } \\
\text { including the manufacturer's air handler } \\
\text { enclosure. All register boots shall be taped or } \\
\text { otherwise sealed during the test. If the air } \\
\text { handler is not installed at the time of the test, } \\
\text { total leakage shall be less than or equal to } 4 \\
\text { cfm ( } 113.3 \mathrm{~L} / \text { min) per } 100 \mathrm{ft} 2 \text { ( } 9.29 \mathrm{~m} 2) \text { of } \\
\text { conditioned floor area. } \\
\text { Exceptions: Duct tightness test is not } \\
\text { required if the air handler and all ducts are } \\
\text { located within conditioned space. }\end{array}$ & $\begin{array}{l}\text { (Mandatory) } 14 \text {. For all homes that have less } \\
\text { than } 1,200 \text { sq } \mathrm{ft} \text { of conditioned floor area (CFA), } \\
\text { total measured duct leakage shall be }<8 \text { CFM } 25 \\
\text { per } 100 \text { sq. } \mathrm{ft} \text { of CFA and measured duct leakage } \\
\text { to outdoors shall be }<5 \text { CFM25 per } 100 \text { sq. ft. of } \\
\text { CFA. } \\
15 \text {. If total duct leakage is }<4 \text { CFM } 25 \text { per } 100 \text { sq. } \\
\text { ft. of conditioned floor area, or }<5 \text { CFM25 per } \\
100 \text { sq. ft. of conditioned floor area for homes that } \\
\text { have less than } 1,200 \text { sq. ft. of conditioned floor } \\
\text { area, then leakage to outdoors need not be tested. }\end{array}$ & $\begin{array}{l}\text { Mandatory - ENERGY STAR V3 requirement } \\
\text { meets the } 2009 \text { IECC requirement. }\end{array}$ \\
\hline Mandatory & $\begin{array}{l}\text { 403.2 Ducts. } 403.2 .3 \\
\text { Building cavities. }\end{array}$ & $\begin{array}{l}\text { Building framing cavities shall not be used as } \\
\text { supply ducts. }\end{array}$ & $\begin{array}{l}\text { (Mandatory) HVAC System Quality } \\
\text { Installation Contractor Checklist } \\
2.0 \text { Duct Quality Installation- Applies to all } \\
\text { heating, cooling, ventilation, exhaust, and } \\
\text { pressure balancing ducts. 2.5 Building cavities not } \\
\text { used as supply or return ducts unless they meet } \\
\text { items 3.2, 3.3, 4.1, and } 4.2 \text { of this checklist. } \\
\text { 3.2 Prescriptive Path: Supply duct in } \\
\text { unconditioned attic have insulation } \geq \text { R-8. } \\
\text { Performance Path: Supply ducts in unconditioned } \\
\text { attic space have insulation } \geq \text { R-6. } 3.3 \text { All other }\end{array}$ & $\begin{array}{l}\text { Mandatory - ENERGY STAR V3 requirement } \\
\text { meets the } 2009 \text { IECC requirement. }\end{array}$ \\
\hline
\end{tabular}




\begin{tabular}{|c|c|c|c|c|}
\hline $\begin{array}{l}\text { Requirement } \\
\text { Category }\end{array}$ & $\begin{array}{l}\text { IECC Requirement } \\
\text { Reference }\end{array}$ & IECC 2009 & ES3 & Comments \\
\hline & & & $\begin{array}{l}\text { supply ducts and all return ducts in unconditioned } \\
\text { space have insulation } \geq \text { R- } 6 \text {. } 4.1 \text { Total Rater- } \\
\text { measured duct leakage } \leq 6 \text { CFM } 25 \text { per } 100 \text { sq. ft. } \\
\text { of conditioned floor area. } 4.2 \text { Rater-measured duct } \\
\text { leakage to outdoors } \leq 4 \text { CFM } 25 \text { per } 100 \text { sq. ft. of } \\
\text { conditioned floor area. }\end{array}$ & \\
\hline Mandatory & $\begin{array}{l}\text { 403.3 Mechanical } \\
\text { system piping } \\
\text { insulation. }\end{array}$ & $\begin{array}{l}\text { Mechanical system piping capable of } \\
\text { carrying fluids above } 105^{\circ} \mathrm{F}\left(41^{\circ} \mathrm{C}\right) \text { or } \\
\text { below } 55^{\circ} \mathrm{F}\left(13^{\circ} \mathrm{C}\right) \text { shall be insulated to a } \\
\text { minimum of R-3. }\end{array}$ & - & Not explicitly mentioned in ENERGY STAR V3. \\
\hline Mandatory & $\begin{array}{l}\text { 403.4 Circulating hot } \\
\text { water systems. }\end{array}$ & $\begin{array}{l}\text { All circulating service hot water piping shall } \\
\text { be insulated to at least R-2. Circulating hot } \\
\text { water systems shall include an automatic or } \\
\text { readily accessible manual switch that can } \\
\text { turn off the hot water circulating pump when } \\
\text { the system is not in use. }\end{array}$ & - & Not explicitly mentioned in ENERGY STAR V3. \\
\hline Mandatory & $\begin{array}{l}403.5 \text { Mechanical } \\
\text { ventilation. }\end{array}$ & $\begin{array}{l}\text { Outdoor air intakes and exhausts shall have } \\
\text { automatic or gravity dampers that close when } \\
\text { the ventilation system is not operating. }\end{array}$ & - & Not explicitly mentioned in ENERGY STAR V3. \\
\hline Mandatory & 403.6 Equipment sizing. & $\begin{array}{l}\text { Heating and cooling equipment shall be sized } \\
\text { in accordance with Section M1401.3 of the } \\
\text { International Residential Code. }\end{array}$ & $\begin{array}{l}\text { (Mandatory) HVAC System Quality } \\
\text { Installation Contractor Checklist } \\
1.0 \text { Heating and cooling loads shall be calculated, } \\
\text { equipment capacity shall be selected, and duct } \\
\text { systems shall be sized according to the latest } \\
\text { editions of ACCA Manuals J, S, and D, } \\
\text { respectively, ASHRAE } 2009 \text { Handbook of } \\
\text { Fundamentals, or a substantively equivalent } \\
\text { procedure. }\end{array}$ & $\begin{array}{l}\text { Mandatory - ENERGY STAR V3 requirement } \\
\text { meets the } 2009 \text { IECC requirement. }\end{array}$ \\
\hline Mandatory & $\begin{array}{l}\text { 403.7 Systems serving } \\
\text { multiple dwelling units. }\end{array}$ & $\begin{array}{l}\text { Systems serving multiple dwelling units shall } \\
\text { comply with Sections } 503 \text { and } 504 \text { in lieu of } \\
\text { Section } 403 .\end{array}$ & - & $\begin{array}{l}\text { Commercial requirements are outside of the } \\
\text { scope of this analysis. }\end{array}$ \\
\hline Mandatory & $\begin{array}{l}\text { 403.8 Snow melt system } \\
\text { controls. }\end{array}$ & $\begin{array}{l}\text { Snow- and ice-melting systems, supplied } \\
\text { through energy service to the building, shall } \\
\text { include automatic controls capable of } \\
\text { shutting off the system when the pavement } \\
\text { temperature is above } 50^{\circ} \mathrm{F} \text {, and no } \\
\text { precipitation is falling and an automatic or } \\
\text { manual control that will allow shutoff when } \\
\text { the outdoor temperature is above } 40^{\circ} \mathrm{F} \text {. }\end{array}$ & - & Not explicitly mentioned in ENERGY STAR V3. \\
\hline Mandatory & $\begin{array}{l}\text { 403.9 Pools. } 403.9 .1 \\
\text { Pool heaters. }\end{array}$ & $\begin{array}{l}\text { Pools shall be provided with energy- } \\
\text { conserving measures in accordance with } \\
\text { Sections } 403.9 .1 \text { through } 403.9 .3 \text {. } \\
\text { 403.9.1 Pool heaters. All pool heaters shall } \\
\text { be equipped with a readily accessible on-off } \\
\text { switch to allow shutting off the heater } \\
\text { without adjusting the thermostat setting. Pool } \\
\text { heaters fired by natural gas or LPG shall not }\end{array}$ & - & Not explicitly mentioned in ENERGY STAR V3. \\
\hline
\end{tabular}




\begin{tabular}{|c|c|c|c|c|}
\hline $\begin{array}{c}\text { Requirement } \\
\text { Category }\end{array}$ & $\begin{array}{c}\text { IECC Requirement } \\
\text { Reference }\end{array}$ & IECC 2009 & ES3 & Comments \\
\hline & & have continuously burning pilot lights. & & \\
\hline Mandatory & $\begin{array}{l}\text { 403.9 Pools. } 403.9 .2 \\
\text { Time switches. }\end{array}$ & $\begin{array}{l}\text { Time switches that can automatically turn off } \\
\text { and on heaters and pumps according to a } \\
\text { preset schedule shall be installed on } \\
\text { swimming pool heaters and pumps. } \\
\text { Exceptions: } \\
\text { 1. Where public health standards require 24- } \\
\text { hour pump operation. } \\
\text { 2. Where pumps are required to operate } \\
\text { solar- and waste-heat-recovery pool heating } \\
\text { systems. }\end{array}$ & - & Not explicitly mentioned in ENERGY STAR V3. \\
\hline Mandatory & $\begin{array}{l}\text { 403.9 Pools. } 403.9 .3 \\
\text { Pool covers. }\end{array}$ & $\begin{array}{l}\text { Heated pools shall be equipped with a vapor- } \\
\text { retardant pool cover on or at the water } \\
\text { surface. Pools heated to more than } 90^{\circ} \mathrm{F} \\
\left(32^{\circ} \mathrm{C}\right) \text { shall have a pool cover with a } \\
\text { minimum insulation value of R- } 12 \text {. } \\
\text { Exception: Pools deriving over } 60 \text { percent of } \\
\text { the energy for heating from site-recovered } \\
\text { energy or solar energy source. }\end{array}$ & - & Not explicitly mentioned in ENERGY STAR V3. \\
\hline Prescriptive & $\begin{array}{l}\text { 404.1 Lighting } \\
\text { equipment. }\end{array}$ & $\begin{array}{l}\text { A minimum of } 50 \text { percent of the lamps in } \\
\text { permanently installed lighting fixtures shall } \\
\text { be high-efficacy lamps. }\end{array}$ & $\begin{array}{l}\text { Prescriptive Path: ENERGY STAR qualified } \\
\text { CFLs or pin-based lighting in 80\% of fixtures in } \\
\text { RESNET-defined Qualifying Light Fixture } \\
\text { Locations shall be installed. (Alternate: ENERGY } \\
\text { STAR Advanced Lighting Package). }\end{array}$ & $\begin{array}{l}\text { Prescriptive Path: ENERGY STAR V3 } \\
\text { requirement meets the } 2009 \text { IECC requirement. } \\
\text { Performance Path: ENERGY STAR V3 } \\
\text { requirement does not meet the } 2009 \text { IECC } \\
\text { requirement. }\end{array}$ \\
\hline Performance & $\begin{array}{l}405.2 \text { Mandatory } \\
\text { requirements. }\end{array}$ & $\begin{array}{l}\text { Compliance with this section requires that } \\
\text { the mandatory provisions identified in } \\
\text { Section } 401.2 \text { be met. All supply and return } \\
\text { ducts not completely inside the building } \\
\text { thermal envelope shall be insulated to a } \\
\text { minimum of R-6. }\end{array}$ & $\begin{array}{l}\text { (Mandatory) HVAC System Quality } \\
\text { Installation Contractor Checklist } \\
\text { 3.0 Duct insulation } \\
\text { 3.1 All connections to trunk ducts in } \\
\text { unconditioned space are insulated. } \\
\text { 3.3 All other supply ducts and all return ducts in } \\
\text { unconditioned space have insulation } \geq \text { R-6. }\end{array}$ & $\begin{array}{l}\text { Mandatory - ENERGY STAR V3 requirement } \\
\text { meets the } 2009 \text { IECC requirement. }\end{array}$ \\
\hline Performance & $\begin{array}{l}405.3 \text { Performance- } \\
\text { based compliance. }\end{array}$ & $\begin{array}{l}\text { Compliance based on simulated energy } \\
\text { performance requires that a proposed } \\
\text { residence (proposed design) be shown to } \\
\text { have an annual energy cost that is less than or } \\
\text { equal to the annual energy cost of the } \\
\text { standard reference design. Energy prices } \\
\text { shall be taken from a source approved by the } \\
\text { code official, such as the Department of } \\
\text { Energy, Energy Information } \\
\text { Administration's State Energy Price and } \\
\text { Expenditure Report. Code officials shall be } \\
\text { permitted to require time-of-use pricing in } \\
\text { energy cost calculations. } \\
\text { Exception: The energy use based on source } \\
\text { energy expressed in Btu or Btu per square } \\
\text { foot of conditioned floor area shall be }\end{array}$ & $\begin{array}{l}\text { National Program Requirements. Performance } \\
\text { Path } \\
\text { 1.0 Determine the ENERGY STAR HERS Index } \\
\text { Target, which is the highest numerical HERS } \\
\text { index value that each rated home may achieve to } \\
\text { earn the ENERGY STAR. This target shall be } \\
\text { specifically determined for each rated home by } \\
\text { following the steps outlined in the document } \\
\text { titled, "ENERGY STAR HERS Index Target } \\
\text { Procedure, Version } 3 \text { (Rev. 02)”, available on } \\
\text { EPA“s Web site. This procedure defines how to } \\
\text { configure the ENERGY STAR Reference Design } \\
\text { Home and calculate its associated HERS index } \\
\text { value and then how to apply the appropriate Size } \\
\text { Adjustment Factor to determine the ENERGY } \\
\text { STAR HERS Index Target. Note that EPA will }\end{array}$ & $\begin{array}{l}\text { Performance Path: ENERGY STAR V3 } \\
\text { requirement does not fully comply with the } 2009 \\
\text { IECC. Note that the allowance for equipment } \\
\text { efficiency trade-offs contained in the Performance } \\
\text { Path are not allowed in the IECC } 2009 .\end{array}$ \\
\hline
\end{tabular}




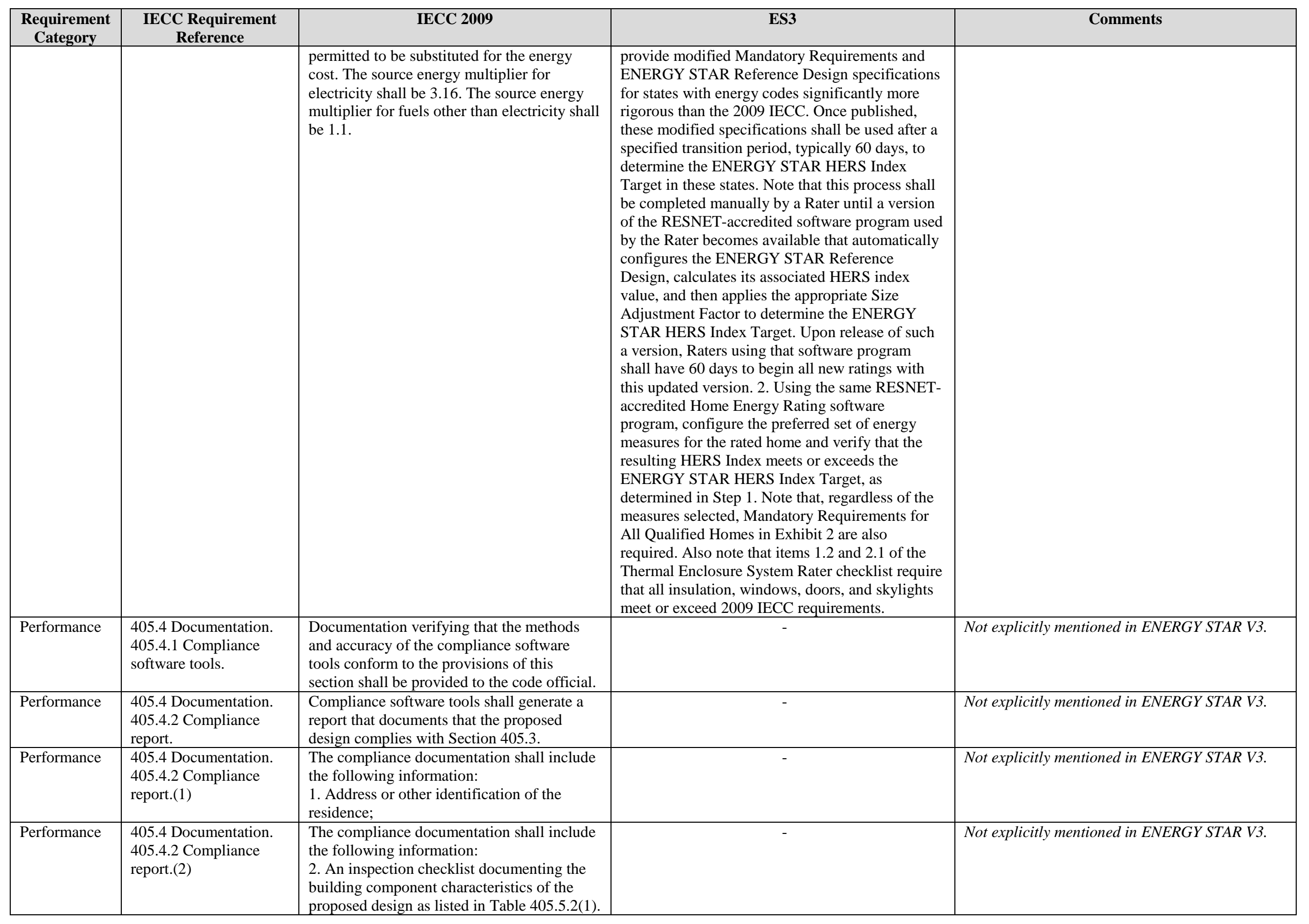




\begin{tabular}{|c|c|c|c|c|}
\hline $\begin{array}{c}\text { Requirement } \\
\text { Category }\end{array}$ & $\begin{array}{c}\text { IECC Requirement } \\
\text { Reference }\end{array}$ & IECC 2009 & ES3 & Comments \\
\hline & & $\begin{array}{l}\text { The inspection checklist shall show results } \\
\text { for both the standard reference design and the } \\
\text { proposed design, and shall document all } \\
\text { inputs entered by the user necessary to } \\
\text { reproduce the results; }\end{array}$ & & \\
\hline Performance & $\begin{array}{l}\text { 405.4 Documentation. } \\
\text { 405.4.2 Compliance } \\
\text { report.(3) }\end{array}$ & $\begin{array}{l}\text { The compliance documentation shall include } \\
\text { the following information: } \\
\text { 3. Name of individual completing the } \\
\text { compliance report; and }\end{array}$ & - & Not explicitly mentioned in ENERGY STAR V3. \\
\hline Performance & $\begin{array}{l}\text { 405.4 Documentation. } \\
\text { 405.4.2 Compliance } \\
\text { report.(4) }\end{array}$ & $\begin{array}{l}\text { The compliance documentation shall include } \\
\text { the following information: } \\
\text { 4. Name and version of the compliance } \\
\text { software tool. } \\
\text { Exception: Multiple orientations. When an } \\
\text { otherwise identical building model is offered } \\
\text { in multiple orientations, compliance for any } \\
\text { orientation shall be permitted by } \\
\text { documenting that the building meets the } \\
\text { performance requirements in each of the four } \\
\text { cardinal (north, east, south and west) } \\
\text { orientations. }\end{array}$ & - & Not explicitly mentioned in ENERGY STAR V3. \\
\hline Performance & $\begin{array}{l}\text { 405.4 Documentation. } \\
\text { 405.4.3 Additional } \\
\text { documentation. }\end{array}$ & $\begin{array}{l}\text { The code official shall be permitted to } \\
\text { require the following documents: } \\
\text { 1. Documentation of the building component } \\
\text { characteristics of the standard reference } \\
\text { design. } \\
\text { 2. A certification signed by the builder } \\
\text { providing the building component } \\
\text { characteristics of the proposed design as } \\
\text { given in Table } 405.5 .2(1) \text {. } \\
\text { 3. Documentation of the actual values used in } \\
\text { the software calculations for the proposed } \\
\text { design. }\end{array}$ & - & Not explicitly mentioned in ENERGY STAR V3. \\
\hline Performance & $\begin{array}{l}405.5 \text { Calculation } \\
\text { procedure. }\end{array}$ & $\begin{array}{l}405.5 .1 \text { General. Except as specified by this } \\
\text { section, the standard reference design and } \\
\text { proposed design shall be configured and } \\
\text { analyzed using identical methods and } \\
\text { techniques. } \\
405.5 .2 \text { Residence specifications. The } \\
\text { standard reference design and proposed } \\
\text { design shall be configured and analyzed as } \\
\text { specified by Table } 405.5 .2(1) \text {. Table } \\
\text { 405.5.2(1) shall include by reference all } \\
\text { notes contained in Table 402.1.1. }\end{array}$ & - & Not explicitly mentioned in ENERGY STAR V3. \\
\hline Performance & $\begin{array}{l}\text { 405.6 Calculation } \\
\text { software tools. } 405.6 .1 \\
\text { Minimum capabilities. } \\
\end{array}$ & $\begin{array}{l}\text { Calculation procedures used to comply with } \\
\text { this section shall be software tools capable of } \\
\text { calculating the annual energy consumption of }\end{array}$ & - & Not explicitly mentioned in ENERGY STAR V3. \\
\hline
\end{tabular}




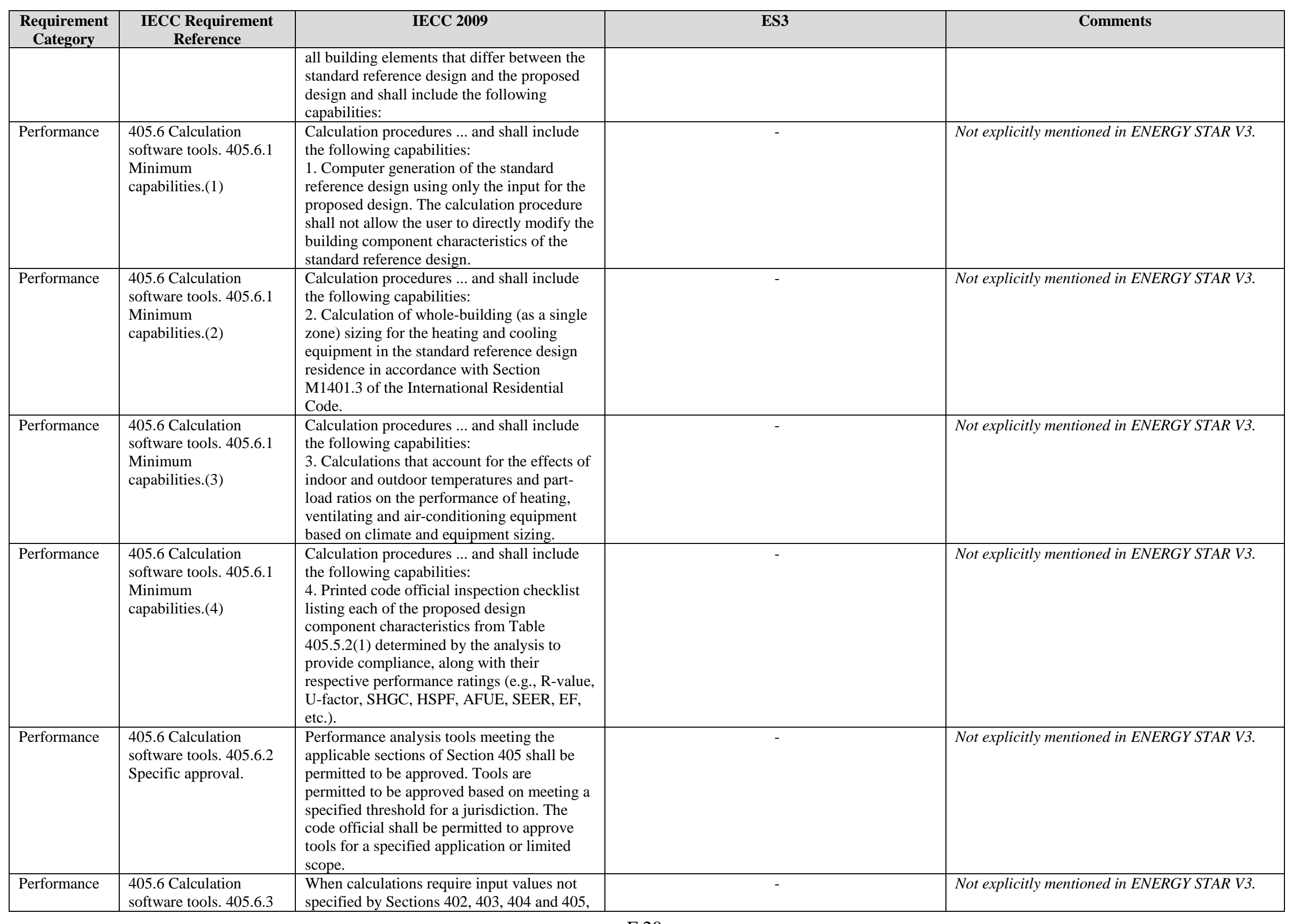




\begin{tabular}{|c|c|c|c|c|}
\hline $\begin{array}{l}\text { Requirement } \\
\text { Category }\end{array}$ & $\begin{array}{c}\text { IECC Requirement } \\
\text { Reference }\end{array}$ & IECC 2009 & ES3 & Comments \\
\hline & Input values. & $\begin{array}{l}\text { those input values shall be taken from an } \\
\text { approved source. }\end{array}$ & & \\
\hline
\end{tabular}


Appendix G

Comprehensive Comparison 


\begin{tabular}{|c|c|c|c|c|c|c|c|c|c|}
\hline Category & Topic & $\begin{array}{l}\text { Requireme } \\
\text { nt category }\end{array}$ & $\begin{array}{c}\text { IECC } \\
\text { Requirement } \\
\text { Reference } \\
\end{array}$ & IECC 2009 & ICC-700 & LEED for Homes & ES2 & ES2.5 & ES3 \\
\hline $\begin{array}{l}\text { Residential } \\
\text { Energy } \\
\text { Efficiency }\end{array}$ & $\begin{array}{l}\text { Building } \\
\text { Thermal } \\
\text { Envelope }\end{array}$ & $\begin{array}{l}\text { Prescriptive } \\
\end{array}$ & $\begin{array}{l}402.1 .1 \\
\text { Insulation and } \\
\text { fenestration } \\
\text { criteria. }\end{array}$ & $\begin{array}{l}\text { The building thermal envelope } \\
\text { shall meet the requirements of } \\
\text { Table } 402.1 .1 \text { based on the } \\
\text { climate zone specified in Chapter } \\
3 .\end{array}$ & $\begin{array}{l}\text { See alternative compliance path under } \\
2009 \text { IECC section 402.1.4. }\end{array}$ & $\begin{array}{l}\text { EA 2: Insulation - Prescriptive Path } \\
\text { Prerequisite 2.1 Basic Insulation } \\
\text { (Mandatory). Meet all the following } \\
\text { requirements: } \\
\text { a) Install insulation that meets or exceeds the } \\
\text { R-value requirements listed in Chapter } 4 \text { of } \\
\text { the 2004 International Energy Conservation } \\
\text { Code. } \\
\text { EA 4: Windows - Prescriptive Path } \\
\text { Prerequisite 4.1 Good Windows } \\
\text { (Mandatory.). Meet all of the following } \\
\text { requirements...design and install windows } \\
\text { and glass doors that have NFRC ratings that } \\
\text { meet or exceed the window requirements of } \\
\text { the ENERGY STAR for Homes national } \\
\text { Builder Otion Package (Table 1). } \\
\text { Credit } 4.2 \text { Enhanced Windows (Optional). } \\
\text { Design and install windows and glass } \\
\text { doors...that exceed...Table 1. } \\
\text { OR } \\
\text { Credit 4.3 Exceptional Windows (Optional). } \\
\text { Design and install windows and glass } \\
\text { doors...that substantially exceed...Table } 1 .\end{array}$ & 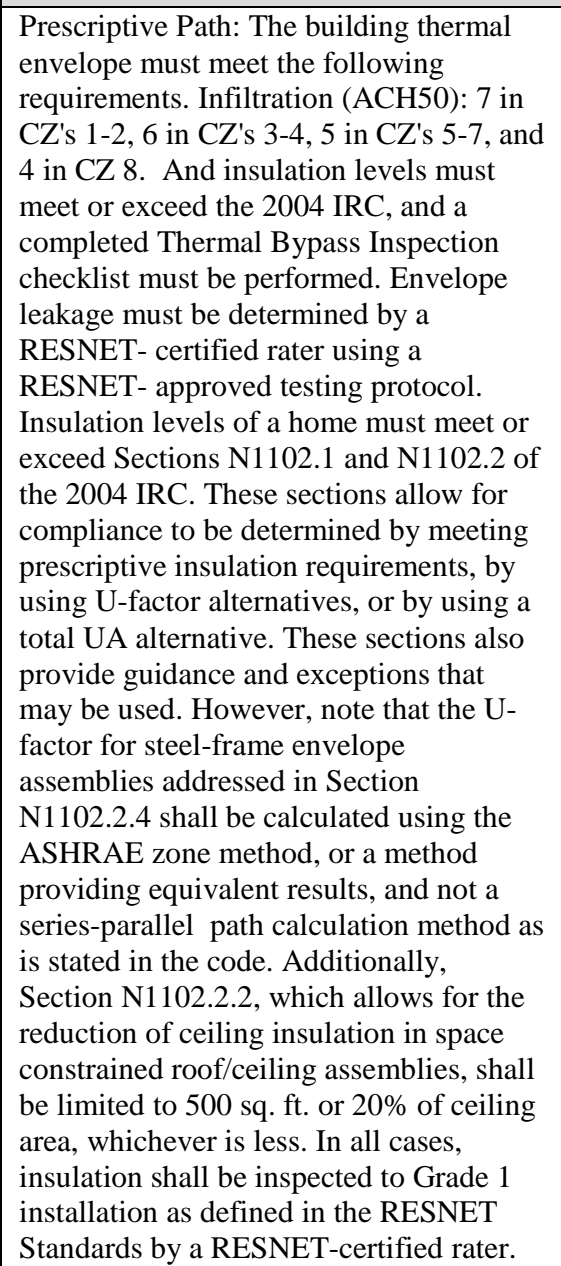 & 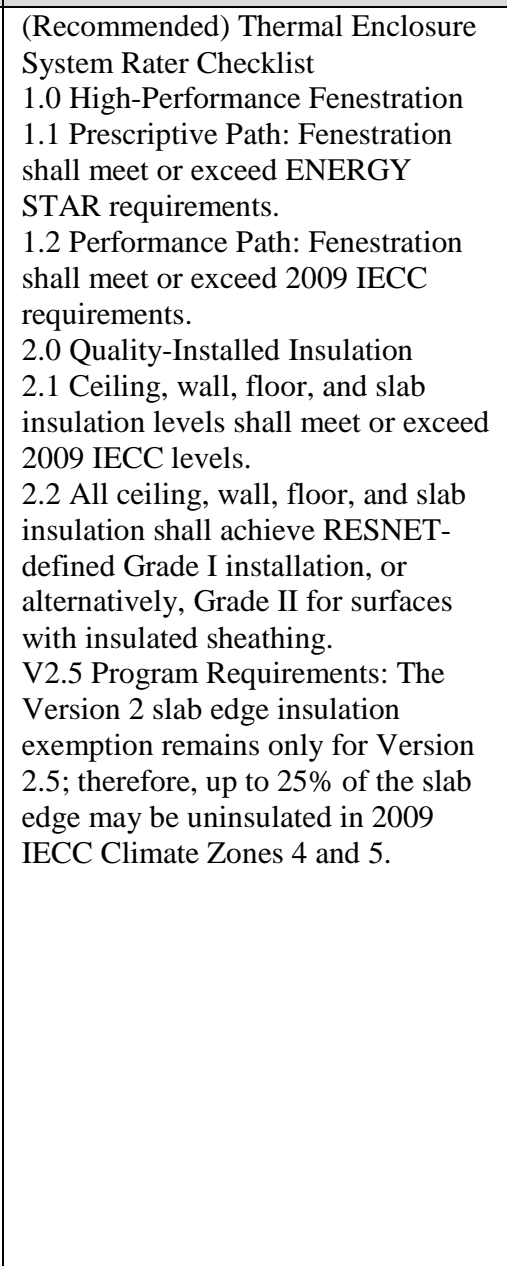 & $\begin{array}{l}\text { (Mandatory) Thermal Enclosure } \\
\text { System Rater Checklist } \\
\text { 1.0 High--erfrormance Fenestration } \\
1.1 \text { Prescriptive Path: Fenestration } \\
\text { shall meet or exceed ENERGY } \\
\text { STAR } R^{*} \text { requirements. } \\
\text { 1.2 Performance Path: Fenestration } \\
\text { shall meet or exceed } 2009 \text { IECC } \\
\text { requirements. } \\
\text { 2.0 Quality-Installed Insulation } \\
\text { 2.1 Ceiling, walll, floor, and slab } \\
\text { insulation levels shall meet or } \\
\text { exceed 2009 IECC levels. } \\
\text { 2.2 All ceiling, wall, floor, and slab } \\
\text { insulation shall achieve RESNET- } \\
\text { defined Grade I installation, or } \\
\text { alternatively, Grade II for surfaces } \\
\text { with insulated sheathing. } \\
\text { *ENERGY STAR Program } \\
\text { Requirements for Residential } \\
\text { Windows, Doors, and Skylights - } \\
\text { Version 5.0 as outlined at } \\
\text { www.energystar.gov/windows. }\end{array}$ \\
\hline $\begin{array}{l}\text { Residential } \\
\text { Energy } \\
\text { Efficiency }\end{array}$ & $\begin{array}{l}\text { Building } \\
\text { Thermal } \\
\text { Envelope }\end{array}$ & Prescriptive & $\begin{array}{l}\text { 402.1.2 R-value } \\
\text { computation. }\end{array}$ & $\begin{array}{l}\text { Insulation material used in } \\
\text { layers, such as framing cavity } \\
\text { insulation and insulating } \\
\text { sheathing, shall be summed to } \\
\text { compute the component R-value. } \\
\text { The manufacturer's settled R- } \\
\text { value shall be used for blown } \\
\text { insulation. Computed R-values } \\
\text { shall not include an R-value for } \\
\text { other building materials or air } \\
\text { films. }\end{array}$ & $\begin{array}{l}\text { See alternative compliance path under } \\
2009 \text { IECC section 402.1.4. }\end{array}$ & $\begin{array}{l}\text { EA 2: Insulation - Prescriptive Path } \\
\text { Prerequisite 2.1 Basic Insulation } \\
\text { (Mandatory.). Meet all the following } \\
\text { requirements: } \\
\text { a) Install insulation that meets or exceeds the } \\
\text { R-value requirements listed in Chapter } 4 \text { of } \\
\text { the } 2004 \text { International Energy Conservation } \\
\text { Code. }\end{array}$ & $\begin{array}{l}\text { See alternative compliance path under } \\
\text { 2009 IECC section 402.1.4. }\end{array}$ & $\begin{array}{l}\text { (Recommended) Thermal Enclosure } \\
\text { System Rater Checklist } \\
\text { 1.0 High-Performance Fenestration } \\
1.1 \text { Prescriptive Path: Fenestration } \\
\text { shall meet or exceed ENERGY } \\
\text { STAR* requirements. } \\
\text { 1.2 Performance Path : Fenestration } \\
\text { shall meet or exceed } 2009 \text { IECC } \\
\text { requirements. } \\
\text { *ENERGY STAR Program } \\
\text { Requirements for Residential } \\
\text { Windows, Doors, and Skylights - } \\
\text { Version 5.0 as outlined at } \\
\text { www.energystar.gov/windows. }\end{array}$ & \begin{tabular}{|l} 
(Mandatory) Thermal Enclosure \\
System Rater Checklist \\
1.0 High-Performance Fenestration \\
1.1 Prescriptive Path: Fenestration \\
shall meet or exceed ENERGY \\
STAR* requirements. \\
1.2 Performance Path : \\
Fenestration shall meet or exceed \\
2009 IECC requirements. \\
\\
*ENERGY STAR Program \\
Requirements for Residential \\
Windows, Doors, and Skylights - \\
Version 5.0 as outlined at \\
www.energystar.gov/windows.
\end{tabular} \\
\hline $\begin{array}{l}\text { Residential } \\
\text { Energy } \\
\text { Efficiency }\end{array}$ & $\begin{array}{l}\text { Building } \\
\text { Thermal } \\
\text { Envelope }\end{array}$ & Prescriptive & $\begin{array}{l}402.1 .3 \mathrm{U}- \\
\text { factor } \\
\text { alternative. }\end{array}$ & $\begin{array}{l}\text { An assembly with a U-factor } \\
\text { equal to or less than that } \\
\text { specified in Table } 402.1 .3 \text { shall } \\
\text { be permitted as an alternative to } \\
\text { the R-value in Table } 402.1 .1 \text {. }\end{array}$ & $\begin{array}{l}\text { See alternative compliance path under } \\
2009 \text { IECC section 402.1.4. }\end{array}$ & $\begin{array}{l}\text { EA 2: Insulation - Prescriptive Path } \\
\text { Prerequisite 2.1 Basic Insulation } \\
\text { (Mandatory. Meet all the following } \\
\text { requirements: } \\
\text { a) Install insulation that meets or exceeds the } \\
\text { R-value requirements listed in Chapter } 4 \text { of } \\
\text { the } 2004 \text { International Energy Conservation } \\
\text { Code. }\end{array}$ & $\begin{array}{l}\text { Prescriptive Path: The building thermal } \\
\text { envelope must meet the following } \\
\text { requirements. Infiltration (ACH50): } 7 \text { in } \\
\text { CZ's 1-2, 6 in CZ's 3-4, } 5 \text { in CZ's 5-7, and } \\
4 \text { in CZ 8. And insulation levels must } \\
\text { meet or exceed the 2004 IRC, and a } \\
\text { completed Thermal Bypass Inspection } \\
\text { checklist must be performed. Envelope } \\
\text { leakage must be determined by a } \\
\text { RESNET- certified rater using a } \\
\text { RESNET- approved testing protocol. } \\
\text { Insulation levels of a home must meet or } \\
\text { exceed Sections N1102.1 } 1 \text { and N1102.2 of }\end{array}$ & $\begin{array}{l}\text { (Recommended) Program } \\
\text { Requirements } \\
6.0 \text { Insulation levels in a home shall } \\
\text { meet or exceed the component } \\
\text { insulation requirements in the } 2009 \\
\text { IECC - Table 402.1.1. The following } \\
\text { exceptions apply: } \\
\text { a. Steel-frame ceilings, walls, and } \\
\text { floors shall meet the insulation } \\
\text { requirements of the 2009 IIECC - } \\
\text { Table 402.2.5. In CZ } 1 \text { and 2, the } \\
\text { continuous insulation requirements in } \\
\text { this table shall be permitted to be }\end{array}$ & $\begin{array}{l}\text { (Mandatory) Program } \\
\text { Requirements } \\
\text { 6.0 Insulation levels in a home } \\
\text { shall meet or exceed the } \\
\text { component insulation requirements } \\
\text { in the 2009 IECC - Table 402.1.1. } \\
\text { The } \\
\text { following exceptions apply: } \\
\text { a. Steel-frame ceilings, walls, and } \\
\text { floors shall meet the insulation } \\
\text { requirements of the 2009 IECC - } \\
\text { Table 402.2.5. In CZ } 1 \text { and 2, the } \\
\text { continuous insulation requirements }\end{array}$ \\
\hline
\end{tabular}




\begin{tabular}{|c|c|c|c|c|c|c|c|c|c|}
\hline Category & Topic & $\begin{array}{l}\text { Requireme } \\
\text { nt category }\end{array}$ & $\begin{array}{c}\text { IECC } \\
\text { Requirement } \\
\text { Reference } \\
\end{array}$ & IECC 2009 & ICC-700 & LEED for Homes & ES2 & ES2.5 & ES3 \\
\hline & & & & & & & $\begin{array}{l}\text { the 2004 IRC. These sections allow for } \\
\text { compliance to be determined by meeting } \\
\text { prescriptive insulation requirements, by } \\
\text { using U-factor alternatives, or by using a } \\
\text { total UA alternative. These sections also } \\
\text { provide guidance and exceptions that } \\
\text { may be used. However, note that the U- } \\
\text { factor for steel-frame envelope } \\
\text { assemblies addressed in Section } \\
\text { N11102.2.2 shall be calculated using the } \\
\text { ASHRAE zone method, or a method } \\
\text { providing equivalent results, and not a } \\
\text { series-parallel path calculation method as } \\
\text { is stated in the code. Additionally, } \\
\text { Section N1102.2.2. which allows for the } \\
\text { reduction of ceiling insulation in space } \\
\text { constrained roof/ceiling assemblies, shall } \\
\text { be limited to 500 sq. ft. or 20\% of ceiling } \\
\text { area, whichever is less. In all cases, } \\
\text { insulation shall be inspected to Grade } 1 \\
\text { installation as defined in the RESNET } \\
\text { Standards by a RESNET-certified rater. }\end{array}$ & 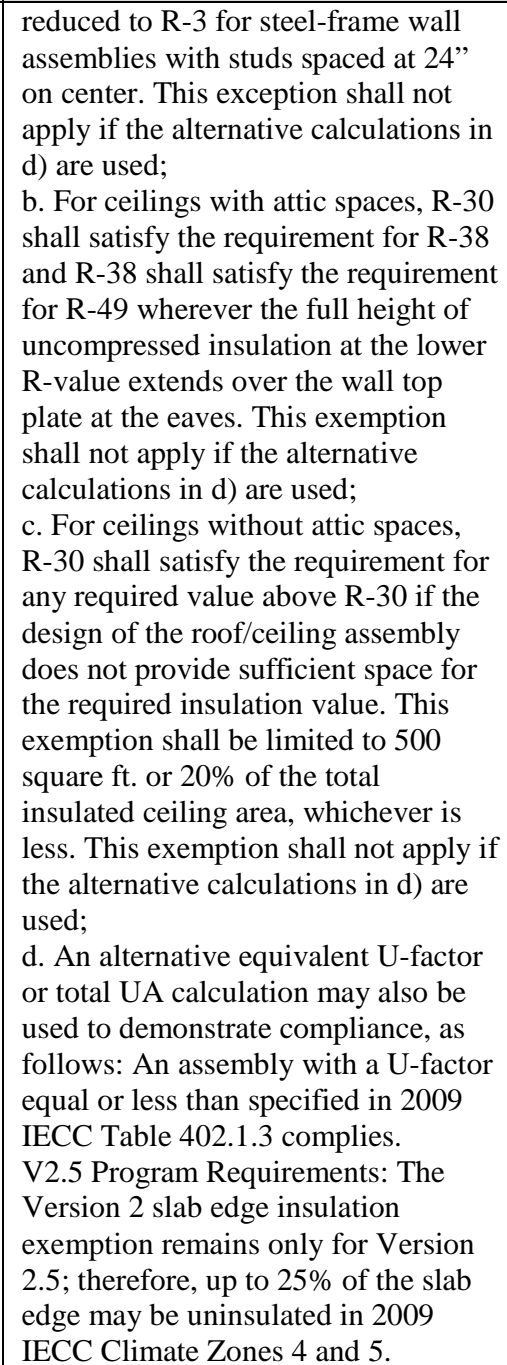 & 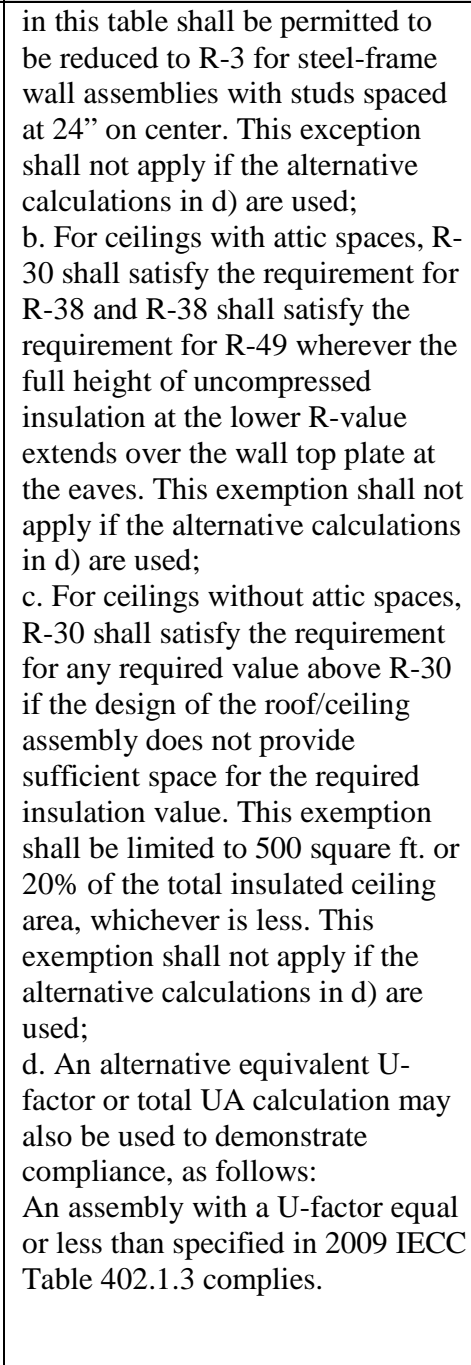 \\
\hline $\begin{array}{l}\text { Residential } \\
\text { Energy } \\
\text { Efficiency }\end{array}$ & $\begin{array}{l}\text { Building } \\
\text { Thermal } \\
\text { Envelope }\end{array}$ & $\begin{array}{l}\text { Prescriptive } \\
\end{array}$ & $\begin{array}{l}\text { 402.1.4 Total } \\
\text { UA alternative. }\end{array}$ & $\begin{array}{l}\text { If the total building thermal } \\
\text { envelope UA... is less than or } \\
\text { equal to the total UA resulting } \\
\text { from using the U-factors in } \\
\text { Table 402.1.3....., the building } \\
\text { shall be considered in } \\
\text { compliance with Table 402.1.1. } \\
\text { The UA calculation shall be } \\
\text { done using a method consistent } \\
\text { with the ASHRAE Handbook of } \\
\text { Fundamentals and shall include } \\
\text { the thermal bridging effects of } \\
\text { framing materials. The SHGC } \\
\text { requirements shall be met in } \\
\text { addition to the UA compliance. }\end{array}$ & $\begin{array}{l}703.1 \text { Building Envelope } \\
\text { 703.l.1 (Optional, Prescriptive path) } \\
\text { Where the total building thermal } \\
\text { envelope UA is less than required by the } \\
2006 \text { IECC Section 402.1.4, the total } \\
\text { building thermal envelope UA is in } \\
\text { accordance with Table 703.1.1. Where } \\
\text { insulation is used to achieve these } \\
\text { percentagese, a thirdd-party grading of the } \\
\text { installation as achieving Grade } 1 \text { is } \\
\text { required. }\end{array}$ & $\begin{array}{l}\text { EA 2: Insulation - Prescriptive Path } \\
\text { Prerequisitit 2.1 Basic Insulation } \\
\text { (Mandatory). Meet all the following } \\
\text { requirements: } \\
\text { a) Install insulation that meets or exceeds the } \\
\text { R-value requirements listed in Chapter } 4 \text { of } \\
\text { the 2004 International Energy Conservation } \\
\text { Code. }\end{array}$ & 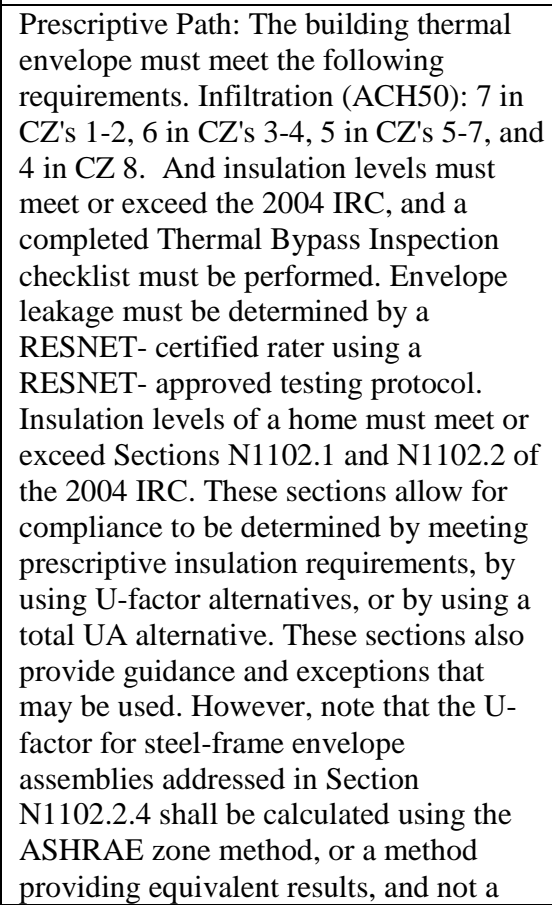 & \begin{tabular}{|l} 
(Recommended) Program \\
Requirements \\
6.0 Insulation levels in a home shall \\
meet or exceed the component \\
insulation requirements in the 2009 \\
IECC - Table 402.1.1. The following \\
exceptions apply: \\
a. Steel-frame ceilings, walls, and \\
floors shall meet the insulation \\
requirements of the 2009 IECC - \\
Table 402.2.5. In CZ 1 and 2, the \\
continuous insulation requirements in \\
this table shall be permitted to be \\
reduced to R-3 for steel-frame wall \\
assemblies with studs spaced at 24" \\
on center. This exception shall not \\
apply if the alternative calculations in \\
d) are used; \\
b. For ceilings with attic spaces, R-30 \\
shall satisfy the requirement for R-38 \\
and R-38 shall satisfy the requirement \\
for R-49 wherever the full hieght of \\
uncompressed insulation at the lower \\
R-value extends over the wall top \\
plate at the eaves. This exemption
\end{tabular} & $\begin{array}{l}\text { (Mandatory) Program } \\
\text { Requirements } \\
\text { 6.0 Insulation levels in a home } \\
\text { shall meet or exceed the } \\
\text { component insulation requirements } \\
\text { in the 2009 IECC - Table 402.1.1. } \\
\text { The following exceptions apply: } \\
\text { a. Steel-frame ceilings, walls, and } \\
\text { floors shall meet the insulation } \\
\text { requirements of the 2009 IECC - } \\
\text { Table 402.2.5. In CZ } 1 \text { and 2, the } \\
\text { continuous insulation requirements } \\
\text { in this table shall be permitted to } \\
\text { be reduced to R-3 for steel-frame } \\
\text { wall assemblies with studs spaced } \\
\text { at 24" on center. This exception } \\
\text { shall not apply if the alternative } \\
\text { calculations in d) are used; } \\
\text { b. For ceilings with attic spaces, R- } \\
\text { 30 shall satisfy the requirement for } \\
\text { R-33 and R-38 shall satisfy the } \\
\text { requirement for R-49 wherever the } \\
\text { full height of uncompressed the } \\
\text { insulation at the lower R-value } \\
\text { extends over the wall top plate at }\end{array}$ \\
\hline
\end{tabular}




\begin{tabular}{|c|c|c|c|c|c|c|c|c|c|}
\hline Category & Topic & $\begin{array}{l}\text { Requireme } \\
\text { nt category }\end{array}$ & $\begin{array}{c}\text { IECC } \\
\text { Requirement } \\
\text { Reference }\end{array}$ & IECC 2009 & ICC-700 & LEED for Homes & ES2 & ES2.5 & ES3 \\
\hline & & & & & & & $\begin{array}{l}\text { series-parallel path calculation method as } \\
\text { is stated in the code. Additionally, } \\
\text { Section N1102.2.2. which allows for the } \\
\text { reduction of ceiling insulation in space } \\
\text { constrained roof/ceiling assemblies, shall } \\
\text { be limited to } 500 \text { sq. ft. or } 20 \% \text { of ceiling } \\
\text { area, whichever is less. In all cases, } \\
\text { insulation shall be inspected to Grade } 1 \\
\text { installation as defined in the RESNET } \\
\text { Standards by a RESNET-certified rater. }\end{array}$ & $\begin{array}{l}\text { shall not apply if the alternative } \\
\text { calculations in d) are used; } \\
\text { c. For ceilings without attic spaces, } \\
\text { R-30 shall satisfy the requirement for } \\
\text { any required value above R-30 if the } \\
\text { design of the roof/ceiling assembly } \\
\text { does not provide sufficient space for } \\
\text { the required insulation value. This } \\
\text { exemption shall be limited to } 500 \\
\text { square ft. or } 20 \% \text { of the total } \\
\text { insulated ceeiling area, whichever is } \\
\text { less. This exemption shall not apply if } \\
\text { the alternative calculations in d) are } \\
\text { used; } \\
\text { d. An alternative equivalent U-factor } \\
\text { or total UA calculation may also be } \\
\text { used to demonstrate compliance, as } \\
\text { follows: An assembly with a U-factor } \\
\text { equal or less than specified in } 2009 \\
\text { IECC Table } 402.1 .3 \text { complies. }\end{array}$ & $\begin{array}{l}\text { the eaves. This exemption shall not } \\
\text { apply if the alternative calculations } \\
\text { in d) are used; } \\
\text { c. For ceilings without attic spaces, } \\
\text { R-30 shall satisfy the requirement } \\
\text { for any required value above R-30 } \\
\text { if the design of the roof/ceiling } \\
\text { assembly does not provide } \\
\text { sufficient space for the required } \\
\text { insulation value. This exemption } \\
\text { shall be limited to } 500 \text { square ft. or } \\
20 \% \text { of the total insulated ceiling } \\
\text { area, whichever is less. This } \\
\text { exemption shall not apply if the } \\
\text { alternative calculations in d) are } \\
\text { used; } \\
\text { d. An alternative equivalent U- } \\
\text { factor or total UA calculation may } \\
\text { also be used to demonstrate } \\
\text { compliance, as follows: An } \\
\text { assembly with a U-factor equal or } \\
\text { less than specified in } 2009 \text { IECC } \\
\text { Table } 402.1 .3 \text { complies. }\end{array}$ \\
\hline $\begin{array}{l}\text { Residential } \\
\text { Energy } \\
\text { Efficiency }\end{array}$ & $\begin{array}{l}\text { Building } \\
\text { Thermal } \\
\text { Envelope }\end{array}$ & Prescriptive & $\begin{array}{l}\text { 402.2 Specific } \\
\text { insulation } \\
\text { requirements. } \\
402.2 .1 \\
\text { Ceeilings with } \\
\text { attic spaces. }\end{array}$ & $\begin{array}{l}\text { When Section } 402.1 .1 \text { would } \\
\text { require R-38 in the ceiling, R-30 } \\
\text { shall be deemed to satisfy the } \\
\text { requirement for R-38 whenever } \\
\text { the full height of uncompressed } \\
\text { R-30 insulation extends over the } \\
\text { wall top plate at the eaves. } \\
\text { Similarly, R-38 shall be deemed } \\
\text { to satisfy the requirements for R- } \\
49 \text { where ever the full height of } \\
\text { uncompressed R-38 insulation } \\
\text { extends sover the top plate at the } \\
\text { eaves. This reduction shall not } \\
\text { apply to the U-factor alternative } \\
\text { approach in Section } 402.1 .3 \text { and } \\
\text { the total UA alternative in } \\
\text { Section 402.1.4. }\end{array}$ & $\begin{array}{l}\text { See alternative compliance path under } \\
2009 \text { IECC section 402.1.4. }\end{array}$ & $\begin{array}{l}\text { EA 2: Insulation - Prescriptive Path } \\
\text { Prerequisite 2.1 Basic Insulation } \\
\text { (Mandatoryy. Meet all the following } \\
\text { requirements: } \\
\text { a) Install insulation that meets or exceeds the } \\
\text { R-value requirements listed in Chapter } 4 \text { of } \\
\text { the } 2004 \text { International Energy Conservation } \\
\text { Code. }\end{array}$ & $\begin{array}{l}\text { (Mandatory) Thermal Bypass Inspection } \\
\text { Checklist } \\
\text { 5.0 Attic/ Ceiling Interface. All attic } \\
\text { penetrations and dropped ceilings include } \\
\text { a full interior air barrier aligned with } \\
\text { insulation with any gaps fully sealed with } \\
\text { caulk, foam or tape. Movable insulation } \\
\text { fits snugly in opening and air burrier is } \\
\text { fully gasketed. } \\
\text { Prescriptive Path: Insulation levels of a } \\
\text { home must meet or exceed Sections } \\
\text { N1102.1 and N1102.2 of the } 2004 \text { IRC. }\end{array}$ & 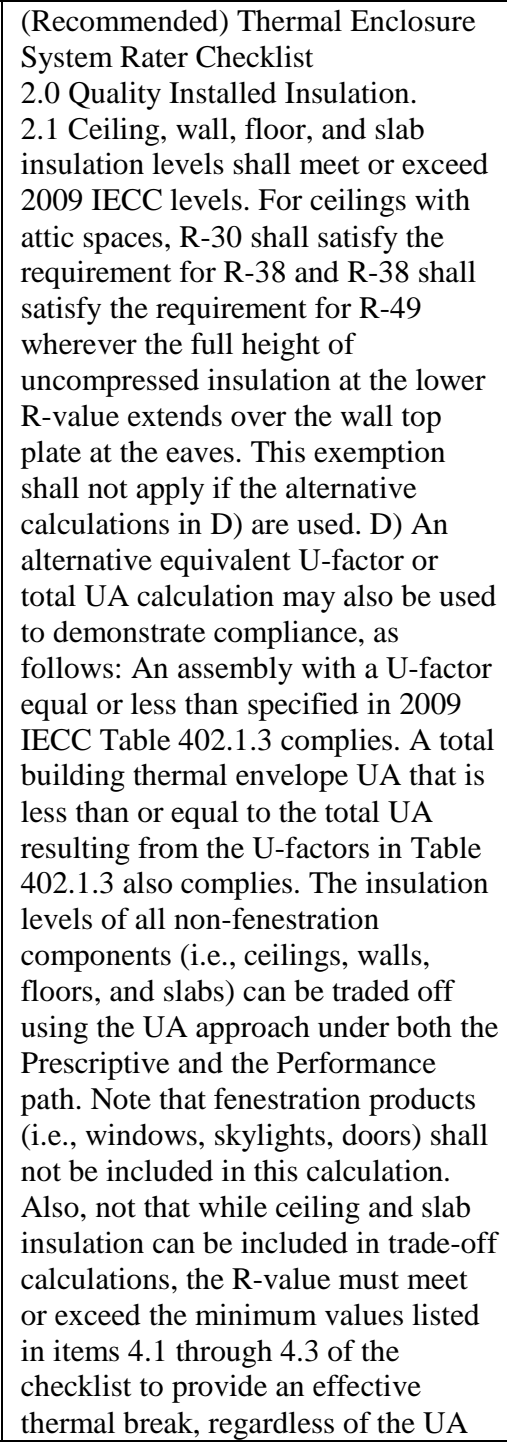 & 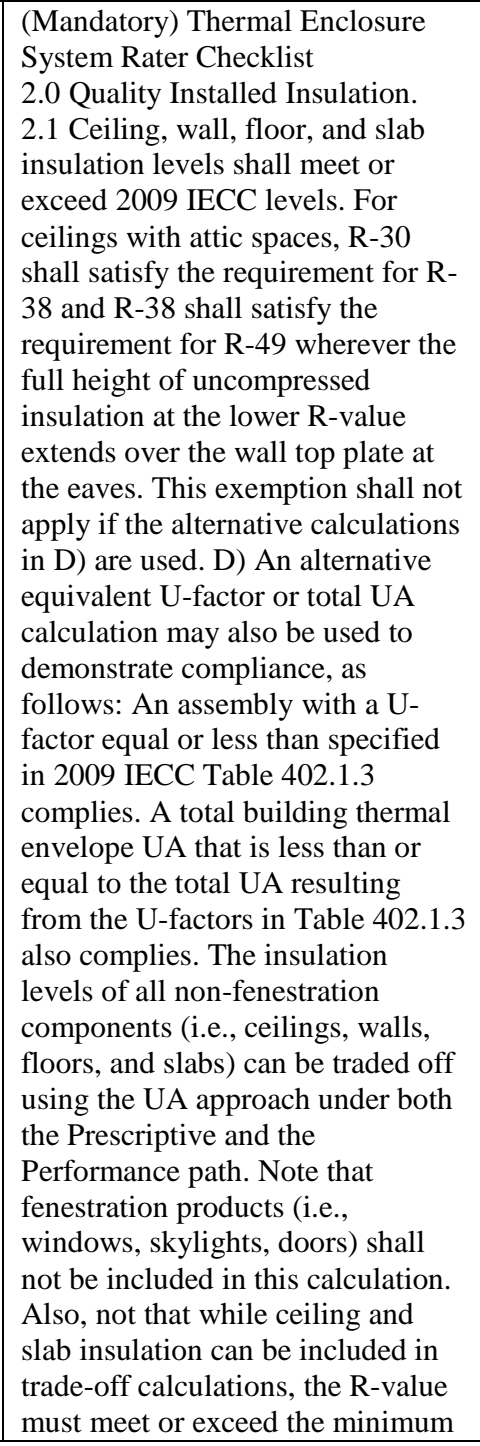 \\
\hline
\end{tabular}




\begin{tabular}{|c|c|c|c|c|c|c|c|c|c|}
\hline Category & Topic & $\begin{array}{l}\text { Requireme } \\
\text { nt category }\end{array}$ & $\begin{array}{c}\text { IECC } \\
\text { Requirement } \\
\text { Reference } \\
\end{array}$ & IECC 2009 & ICC-700 & LEED for Homes & ES2 & ES2.5 & ES3 \\
\hline & & & & & & & & $\begin{array}{l}\text { tradeoffs calculated. The UA } \\
\text { calculation shall be done using a } \\
\text { method consistent with the ASHRAE } \\
\text { Handdoook of Fundamentals and shall } \\
\text { include the thermal bridging effects } \\
\text { of framing materials. The calculation } \\
\text { for a steel-frame envelope assembly } \\
\text { shall use a series-parallel path } \\
\text { calculatation method. } \\
\text { V2.5 Program Requirements: The } \\
\text { Version } 2 \text { slab edge insulation } \\
\text { exemption remains only for Version } \\
\text { 2.5; therefore, up to to } 5 \% \text { of the slab } \\
\text { edge may be uninsulated in } 2009 \\
\text { IECC Climate Zones } 4 \text { and } 5 .\end{array}$ & $\begin{array}{l}\text { values listed in items } 4.1 \text { through } \\
4.3 \text { of the checklist to provide an } \\
\text { effective thermal break, regardless } \\
\text { of the UA tradeoffs calculated. The } \\
\text { UA calculation shall be done using } \\
\text { a method consistent with the } \\
\text { ASHRAE Handbook of } \\
\text { Fundamentals and shall include the } \\
\text { thermal bridging effects of framing } \\
\text { materials. The calculation for a } \\
\text { steel-frame envelope assembly } \\
\text { shall use a series-parallel path } \\
\text { calculation method. }\end{array}$ \\
\hline $\begin{array}{c}\text { Residential } \\
\text { Energy } \\
\text { Efficiency }\end{array}$ & $\begin{array}{l}\text { Building } \\
\text { Thermal } \\
\text { Envelope }\end{array}$ & Prescriptive & $\begin{array}{l}402.2 \text { Specific } \\
\text { insulation } \\
\text { requirements. } \\
402.2 .2 \\
\text { Ceilings } \\
\text { without attic } \\
\text { spaces. }\end{array}$ & 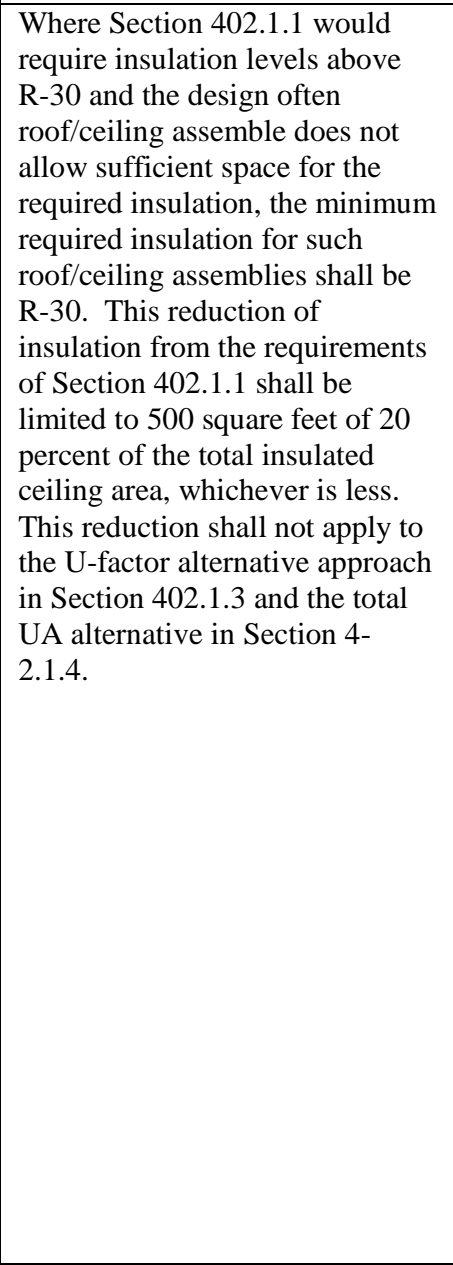 & $\begin{array}{l}\text { See alternative compliance path under } \\
2009 \text { IECC section 402.1.4. }\end{array}$ & $\begin{array}{l}\text { EA 2: Insulation - Prescriptive Path } \\
\text { Prerequisite 2.1 Basic Insulation } \\
\text { (Mandatory). Meet all the following } \\
\text { requirements: } \\
\text { a) Install insulation that meets or exceeds the } \\
\text { R-value requirements listed in Chapter } 4 \text { of } \\
\text { the } 2004 \text { International Energy Conservation } \\
\text { Code. }\end{array}$ & 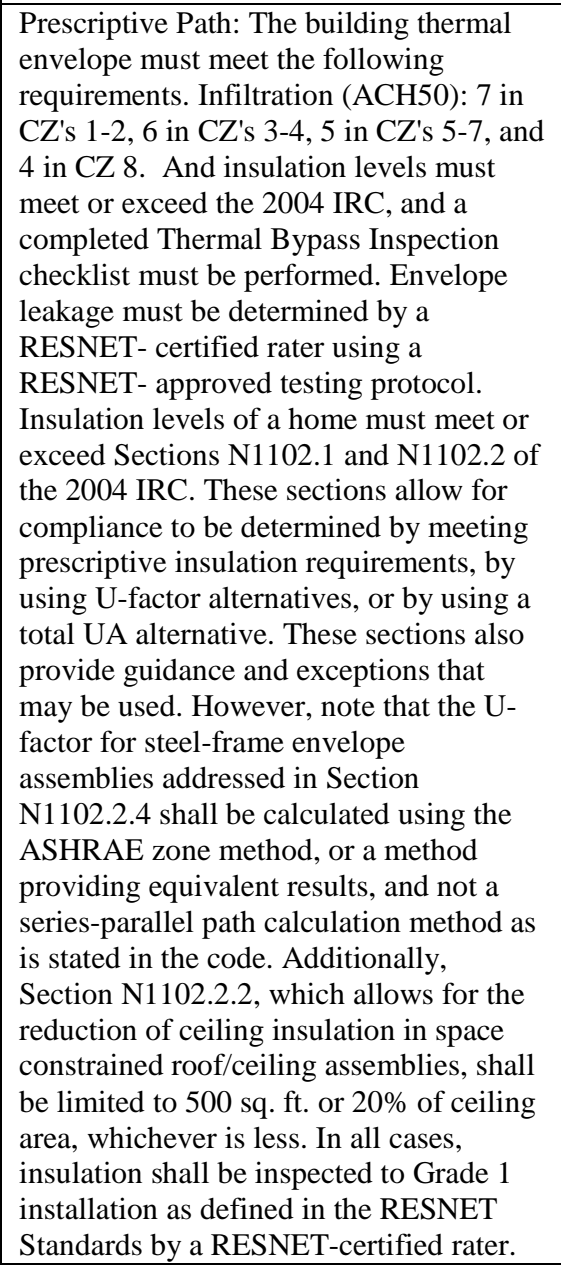 & \begin{tabular}{|l|} 
(Recommended) Thermal Enclosure \\
System Rater Checklist \\
2.0 Quality Installed Insulation. \\
2.1 Ceiling, wall, floor, and slab \\
insulation levels shall meet or exceed \\
2009 IECC levels. For ceilings \\
without attic spaces, R-30 shall satisfy \\
the requirement for any required \\
value above R-30 if the design of the \\
roof/ceiling assembly does not \\
provide sufficient space for the \\
required insulation value. This \\
exception shall be limited to 500 \\
square ft. or 20\% of the total \\
insulated ceiling area, whichever is \\
less. This exemption shall not apply if \\
the alternative calculations in D) are \\
used. \\
V2.5 Program Requirements: The \\
Version 2 slab edge insulation \\
exemption remains only for Version \\
2.5; therefore, up to $25 \%$ of the slab \\
edge may be uninsulated in 2009 \\
IECC Climate Zones 4 and 5.
\end{tabular} & $\begin{array}{l}\text { (Mandatory) Thermal Enclosure } \\
\text { System Rater Checklist } \\
\text { 2.0 Quality Installed Insulation. } \\
\text { 2.1 Celiling, wall, floor, and slab } \\
\text { insulation levels shall meet or } \\
\text { exceed 2009 IECC levels. For } \\
\text { ceilings without attic spaces,R-30 } \\
\text { shall satisfy the requirement for } \\
\text { any required value above R-30 if } \\
\text { the design of the roof/ceiling } \\
\text { assembly does not provide } \\
\text { sufficient space for the required } \\
\text { insulation value. This exception } \\
\text { shall be limited to 500 square ft. or } \\
\text { 20\% of the total insulated ceiling } \\
\text { area, whichevere is less. This } \\
\text { exemption shall not apply if the } \\
\text { alternative calculations in D) are } \\
\text { used. }\end{array}$ \\
\hline $\begin{array}{c}\text { Residential } \\
\text { Energy } \\
\text { Efficiency }\end{array}$ & $\begin{array}{l}\text { Building } \\
\text { Thermal } \\
\text { Envelope }\end{array}$ & Prescriptive & $\begin{array}{l}402.2 \text { Specific } \\
\text { insulation } \\
\text { requirements. } \\
\text { 402.2.3 Access } \\
\text { hatches and } \\
\text { doors. }\end{array}$ & $\begin{array}{l}\text { Access doors from conditioned } \\
\text { spaces to unconditioned spaces } \\
\text { (e.g., attics and crawl spacess } \\
\text { shall be weatherstripped and } \\
\text { insulated to a level equivalent to } \\
\text { the insulation on the surrounding } \\
\text { surfaces. Access shall be } \\
\text { provided to all equipment that } \\
\text { prevents damaging or } \\
\text { compressing the insulation. A } \\
\text { wood framed or equivalent baffle } \\
\text { or retainer is required to be } \\
\text { provided when loose fill }\end{array}$ & $\begin{array}{l}\text { Section 701.4.3.4 Ceilings and attics. (1) } \\
\text { Attic Access (except unvented attics). } \\
\text { (Mandatory) } \\
\text { Attic caccess, knee wall door, or drop- } \\
\text { down stair is covered with insulation and } \\
\text { gasketed. }\end{array}$ & $\begin{array}{l}\text { EA 2: Insulation - Prescriptive Path } \\
\text { Prerequisite 2.1 Basic Insulation } \\
\text { (Mandatory). Meet all the following } \\
\text { requirements: } \\
\text { a) Install insulation that meets or exceeds the } \\
\text { R-value requirements listed in Chapter } 4 \text { of } \\
\text { the } 2004 \text { International Energy Conservation } \\
\text { Code. }\end{array}$ & $\begin{array}{l}\text { (Mandatory) Thermal Bypass Inspection } \\
\text { Checklist } \\
\text { 1.0 Overall Air Barrier and Thermal } \\
\text { Barrier Alignment. Insulation shall be } \\
\text { installed in full contact with sealed } \\
\text { interior and exterior air barrier except for } \\
\text { alternate to interior air barrier under item } \\
\text { no. } 2 \text { (Walls Adjoining Exterior Walls or } \\
\text { Unconditioned Spaced). } \\
5.0 \text { Attic/ Ceiling Interface. All attic } \\
\text { penetrations and dropped ceilings include } \\
\text { a full interior air barrier aligned with } \\
\text { insulation with any gaps fully sealed with }\end{array}$ & \begin{tabular}{|l} 
(Recommended) Thermal Enclosure \\
System Rater Checklist \\
2.0 Quality Installed Insulation. 2.1 \\
Ceiling, wall, floor, and slab \\
insulation levels shall meet or exceed \\
2009 IECC levels. 5.0 Air Sealing 5.3 \\
Other Openings 5.3.2 Attic access \\
panels and drop-down stairs equipped \\
with a durable $\geq$ R-10 insulated cover \\
that is gasketed (i.e., not caulked) to \\
produce continous air seal when \\
occupant is not accessing the attic. \\
V2.5 Program Requirements: The \\
\end{tabular} & $\begin{array}{l}\text { (Mandatory) Thermal Enclosure } \\
\text { System Rater Checklist } \\
\text { 2.0 Quality Installed Insulation. } \\
\text { 2.1 Ceiling, wall, floor, and slab } \\
\text { insulation levels shall meet or } \\
\text { exceed 2009 IECC levels. 5.0 Air } \\
\text { Sealing } \\
5.3 \text { Other Openings } \\
5.3 .2 \text { Attic access panels and drop- } \\
\text { down stairs equipped with a } \\
\text { durable } \geq \text { R-10 insulated cover that } \\
\text { is gasketed (i.e., not caulked) to } \\
\text { produce continuous air seal when }\end{array}$ \\
\hline
\end{tabular}




\begin{tabular}{|c|c|c|c|c|c|c|c|c|c|}
\hline Category & Topic & $\begin{array}{l}\text { Requireme } \\
\text { nt category }\end{array}$ & $\begin{array}{c}\text { IECC } \\
\text { Requirement } \\
\text { Reference }\end{array}$ & IECC 2009 & ICC-700 & LEED for Homes & ES2 & ES2.5 & ES3 \\
\hline & & & & $\begin{array}{l}\text { insulation is installed, the } \\
\text { purpose of which is to prevent } \\
\text { the loose fill insulation from } \\
\text { spilling into the living space } \\
\text { when the attic access is opened, } \\
\text { and to provide a permanent } \\
\text { means of maintaining the } \\
\text { installed R-value of the loose fill } \\
\text { insulation. }\end{array}$ & & & $\begin{array}{l}\text { caulk, foam or tape. Movable insulation } \\
\text { fits snugly in opening and air barrier is } \\
\text { fully gasketed. }\end{array}$ & $\begin{array}{l}\text { Version } 2 \text { slab edge insulation } \\
\text { exemption remains only for Version } \\
2.5 \text {; therefore, up to } 25 \% \text { of the slab } \\
\text { edge may be uninsulated in } 2009 \\
\text { IECC Climate Zones } 4 \text { and } 5 .\end{array}$ & occupant is not accessing the attic. \\
\hline $\begin{array}{l}\text { Residential } \\
\text { Energy } \\
\text { Efficiency }\end{array}$ & $\begin{array}{l}\text { Building } \\
\text { Thermal } \\
\text { Envelope }\end{array}$ & Prescriptive & $\begin{array}{l}\text { 402.2 Specific } \\
\text { insulation } \\
\text { requirements. } \\
\text { 402.2.4 Mass } \\
\text { walls. }\end{array}$ & $\begin{array}{l}\text { Mass walls for the purposes of } \\
\text { this chapter shall be considered } \\
\text { above-grade walls of concrete } \\
\text { block, concrete, insulated } \\
\text { concrete form (ICF), masonry } \\
\text { cavity, brick (other than brick } \\
\text { veneer), earth (adobe, } \\
\text { compressed earth block, rammed } \\
\text { earth) and solid timber/logs. }\end{array}$ & $\begin{array}{l}\text { Section } 202 \text { - Definitions } \\
\text { Mass Walls. Walls constructed of } \\
\text { concrete block, concrete, insulated } \\
\text { concrete form (ICF), masonry cavity, } \\
\text { brick, earth (adobe, compressed earth } \\
\text { block, rammed earth,) and//or solid } \\
\text { timber/logs, with a minimum of } 50 \\
\text { percent of the required R-value on the } \\
\text { exterior of the wall. }\end{array}$ & $\begin{array}{l}\text { EA 2: Insulation - Prescriptive Path } \\
\text { Prerequisite 2.1 Basic Insulation } \\
\text { (Mandatory). Meet all the following } \\
\text { requirements: } \\
\text { a) Install insulation that meets or exceeds the } \\
\text { R-value requirements listed in Chapter } 4 \text { of } \\
\text { the } 2004 \text { International Energy Conservation } \\
\text { Code. }\end{array}$ & 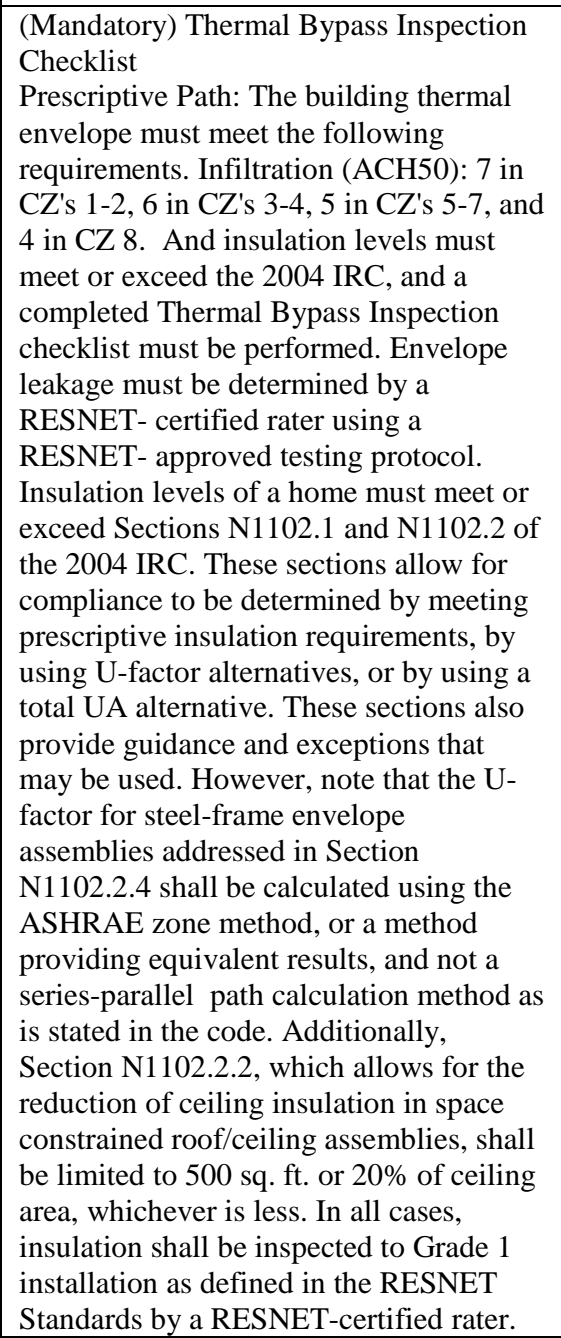 & $\begin{array}{l}\text { (Recommended) Thermal Enclosure } \\
\text { System Rater Checklist } \\
\text { 2.0 Quality Installed Insulation. } \\
2.1 \text { Ceiling, wall, floor, and slab } \\
\text { insulation levels shall meet or exceed } \\
2009 \text { IECC levels. } \\
\text { V2.5 Program Requirements: The } \\
\text { Version 2 slab edge insulation } \\
\text { exemption remains only for Version } \\
\text { 2.5; therefore, up to } 52 \% \text { of the slab } \\
\text { edge may be uninsulated in } 2009 \\
\text { IECC Climate Zones } 4 \text { and } 5 .\end{array}$ & $\begin{array}{l}\text { (Mandatory) Thermal Enclosure } \\
\text { System Rater Checklist } \\
2.0 \text { Quality Installed Insulation. } \\
2.1 \text { Ceiling, wall, floor, and slab } \\
\text { insulation levels shall meet or } \\
\text { exceed 2009 IECC levels. }\end{array}$ \\
\hline $\begin{array}{l}\text { Residential } \\
\text { Energy } \\
\text { Efficiency }\end{array}$ & $\begin{array}{l}\text { Building } \\
\text { Thermal } \\
\text { Envelope }\end{array}$ & $\begin{array}{c}\text { Prescriptive } \\
\end{array}$ & $\begin{array}{l}402.2 \text { Specific } \\
\text { insulation } \\
\text { requirements. } \\
402.2 .5 \text { Steel- } \\
\text { frame ceilings, } \\
\text { walls, and } \\
\text { floors. }\end{array}$ & $\begin{array}{l}\text { Steel-frame ceilings, walls and } \\
\text { floors shall meet the insulation } \\
\text { requirements of Table 402.2.5 or } \\
\text { shall meet the U-factor } \\
\text { requirements in Table 402.1.3. } \\
\text { The calculation of the U-factor } \\
\text { for a steel-frame envelope } \\
\text { assembly shall use a series- } \\
\text { parallel path calculation method. } \\
\text { Exception: In Climate Zones } 1 \\
\text { and 2, the continuous insulation } \\
\text { requirementst in Table 402.2.5 } \\
\text { shall be permitted to be reduced } \\
\text { to R-3 for steel frame wall } \\
\text { assemblies with studs spaced at } \\
24 \text { inches (610 mm) on center. }\end{array}$ & & $\begin{array}{l}\text { EA 2: Insulation - Prescriptive Path } \\
\text { Prerequisite 2.1 Basic Insulation } \\
\text { (Mandatory). Meet all the following } \\
\text { requirements: } \\
\text { a) Install insulation that meets or exceeds the } \\
\text { R-value requirements listed in Chapter } 4 \text { of } \\
\text { the } 2004 \text { International Energy Conservation } \\
\text { Code. }\end{array}$ & 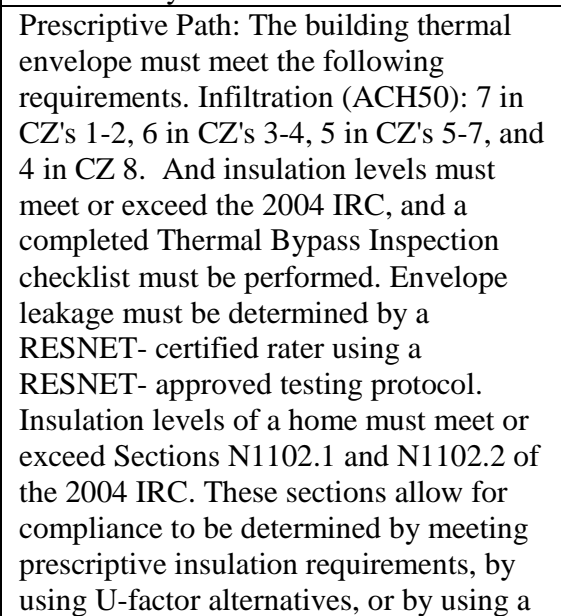 & $\begin{array}{l}\text { (Recommended) Thermal Enclosure } \\
\text { System Rater Checklist } \\
\text { 2.0 Quality Installed Insulation. } \\
\text { 2.1 Ceiling, wall, floor, and slab } \\
\text { insulation levels shall meet or exceed } \\
\text { 2009 IECC levels. Insulation levels in } \\
\text { a home shall meet or exceed the } \\
\text { component insulation requirements in } \\
\text { the 2009 IECC- Table 402.1.1. The } \\
\text { following exceptions apply. A) Steel- } \\
\text { frame ceilings, walls, and floors shall } \\
\text { meet the insulation requirements of } \\
\text { the 2009 IECC - Table 402.2.5. In } \\
\text { climate zones } 1 \text { and } 2 \text {, the continuous } \\
\text { insulation requirements in this table } \\
\text { shall be permitted to be reduced to } R- \\
3 \text { for steel-frame wall assemblies with }\end{array}$ & $\begin{array}{l}\text { (Mandatory) Thermal Enclosure } \\
\text { System Rater Checklist } \\
\text { 2.0 Quality Installed Insulation. } \\
\text { 2.1 Ceiling, wall, floor, and slab } \\
\text { insulation levels shall meet or } \\
\text { exceed 2009 IECC levels. } \\
\text { Insulation levels in a home shall } \\
\text { meet or exceed the component } \\
\text { insulation requirements in the } 2009 \\
\text { IECC- Table 402.1.1. The } \\
\text { following exceptions apply. A) } \\
\text { Steel-frame ceilings, walls, and } \\
\text { floors shall meet the insulation } \\
\text { requirements of the 2009 IECC - } \\
\text { Table 402.2.5. In climate zones } 1 \\
\text { and 2, the continuous insulation } \\
\text { requirements in this table shall be }\end{array}$ \\
\hline
\end{tabular}




\begin{tabular}{|c|c|c|c|c|c|c|c|c|c|}
\hline Category & Topic & $\begin{array}{l}\text { Requireme } \\
\text { nt category }\end{array}$ & $\begin{array}{c}\text { IECC } \\
\text { Requirement } \\
\text { Reference }\end{array}$ & IECC 2009 & ICC-700 & LEED for Homes & ES2 & ES2.5 & ES3 \\
\hline & & & & & & & $\begin{array}{l}\text { total UA alternative. These sections also } \\
\text { provide guidance and exceptions that } \\
\text { may be used. However, note that the U- } \\
\text { factor for steel-frame envelope } \\
\text { assemblies addressed in Section } \\
\text { N1102.2.4 shall be calculated using the } \\
\text { ASHRAAE zone method, or a method } \\
\text { providing gequivalent results, and not a } \\
\text { series-parallel path calculation method as } \\
\text { is stated in the code. Additionally, } \\
\text { Section N1102.2.2. which allows for the } \\
\text { reduction of ceiling insulation in space } \\
\text { constrained roof/ceiling assemblies, shall } \\
\text { be limited to } 500 \text { sq. ff. or 20\% of ceiling } \\
\text { area, whichever is less. In all cases, } \\
\text { insulation shall be inspected to Grade } 1 \\
\text { installation as defined in the RESET } \\
\text { Standards by a RESNET-certified rater. }\end{array}$ & $\begin{array}{l}\text { studs spaced at 24" on center. This } \\
\text { exception shall not apply if the } \\
\text { alternative calculations in D) apply. } \\
\text { D) An alternative equivalent U-factor } \\
\text { or total UA calculation may also be } \\
\text { used to demonstrate compliance, as } \\
\text { follows: An assembly with a U-factor } \\
\text { equal or less than specified in } 2009 \\
\text { IECC Table } 402.1 .3 \text { complies. A total } \\
\text { building thermal envelope UA that is } \\
\text { less than or equal to the total UA } \\
\text { resulting from the U-factors in Table } \\
\text { 402.1.3 also complies. The insulation } \\
\text { levels of all nonofenestration } \\
\text { components (i.e., ceilings, walls, } \\
\text { floors, and slabs) can be traded off } \\
\text { using the UA approach under both the } \\
\text { Prescriptive and the Performance } \\
\text { path. .. The UA calculation shall be } \\
\text { done using a method consistent with } \\
\text { the ASHRAE Handbook of } \\
\text { Fundamentals and shall include the } \\
\text { thermal bridging effects of framing } \\
\text { materials. The calculation for a steel- } \\
\text { frame envelope assembly shall use a } \\
\text { series-parallel pasth calculation } \\
\text { method. } \\
\text { V2.5 Program Requirements: The } \\
\text { Version } 2 \text { slab edge insulation } \\
\text { exemption remains only for Version } \\
\text { 2.5; therefore, up to } 25 \% \text { of the slab } \\
\text { edge may be uninsulated in } 2009 \\
\text { IECC Climate Zones } 4 \text { and } 5 .\end{array}$ & $\begin{array}{l}\text { permitted to be reduced to R-3 for } \\
\text { steel-frame wall assemblies with } \\
\text { studs spaced at 244 on center. This } \\
\text { exception shall not apply if the } \\
\text { alternative calculations in D) } \\
\text { apply. D) An alternative equivalent } \\
\text { U-factor or total UA calculation } \\
\text { may also be used to demonstrate } \\
\text { compliance, as follows: An } \\
\text { assembly with a U-factor equal or } \\
\text { less than specified in } 2009 \text { IECC } \\
\text { Table 402.1.3 complies. A total } \\
\text { building thermal envelope UA that } \\
\text { is less than or equal to the total UA } \\
\text { resulting from the U-factors in } \\
\text { Table 402.1.3 also complies. The } \\
\text { insultation levels of all } \\
\text { nonfenestration components (i.e., } \\
\text { ceilings, walls, floors, and slabs) } \\
\text { can be traded off using the UA } \\
\text { approach under both the } \\
\text { Prescriptive and the Performance } \\
\text { path.... The UA calculation shall } \\
\text { be done using a method consistent } \\
\text { with the ASHRAE Handbook of } \\
\text { Fundamentals and shall include the } \\
\text { thermal bridging effects of framing } \\
\text { materials. The calculation for a } \\
\text { steel-frame envelope assembly } \\
\text { shall use a series-parallel path } \\
\text { calculation method. }\end{array}$ \\
\hline $\begin{array}{l}\text { Residential } \\
\text { Energy } \\
\text { Efficiency }\end{array}$ & $\begin{array}{l}\text { Building } \\
\text { Thermal } \\
\text { Envelope }\end{array}$ & $\begin{array}{l}\text { Prescriptive } \\
\end{array}$ & $\begin{array}{l}402.2 \text { Specific } \\
\text { insulation } \\
\text { requirements. } \\
\text { 402.2.6 Floors. }\end{array}$ & $\begin{array}{l}\text { Floor insulation shall be installed } \\
\text { to maintain permanent contact } \\
\text { witt the underside of the } \\
\text { subfloor decking. }\end{array}$ & $\begin{array}{l}701.4 .3 .2 \text { Floors, foundations, and } \\
\text { crawlspaces (Mandatory) } \\
\text { (1) Floors. (including insulated floors } \\
\text { above garages and cantilevered floors) } \\
\text { (a) Insulation is installeld to maintain } \\
\text { permanent contact with the underside of } \\
\text { the subfloor decking, enveloping any } \\
\text { attached ductwork within the thermal } \\
\text { envelope without compression or air gaps } \\
\text { in the insulation. This practice deos not } \\
\text { apply to ducts or other mechanical } \\
\text { equipment that is adjacent to the } \\
\text { underside of the subfloor. } \\
\text { (b) Batt and loose-fill insulation is held in } \\
\text { place by permanent tattachments or } \\
\text { systems in accordance with the } \\
\text { manufacturer's instructions. }\end{array}$ & $\begin{array}{l}\text { EA 2: Insulation - Prescriptive Path } \\
\text { Prerequisitie 2.1 Basic Insulation } \\
\text { (Mandatory). Meet all the following } \\
\text { requirements: } \\
\text { a) Install insulation that meets or exceeds the } \\
\text { R-value requirements listed in Chapter } 4 \text { of } \\
\text { the 2004 International Energy Conservation } \\
\text { Code. }\end{array}$ & 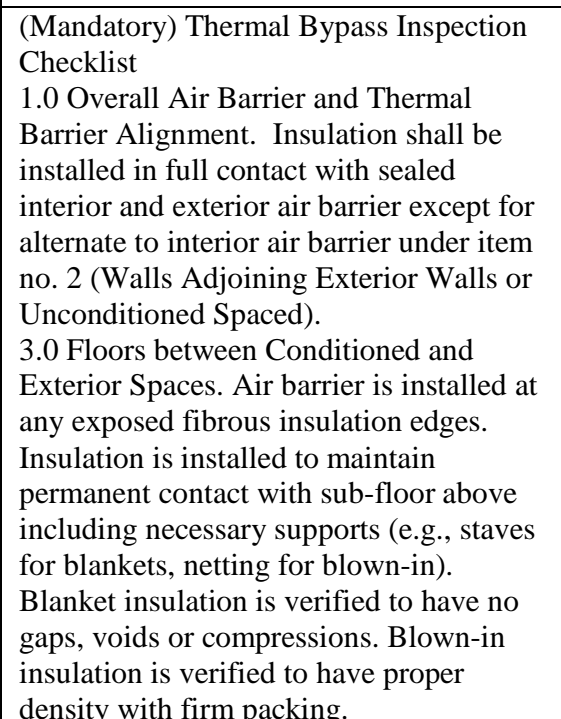 & $\begin{array}{l}\text { (Recommended) Thermal Enclosure } \\
\text { System Rater Checklist } \\
\text { 2.0 Quality Installed Insulation. } \\
\text { 2.1 Ceiling, wall, floor, and slab } \\
\text { insulation levels shall meet or exceed } \\
\text { 2009 IECC levels. } \\
\text { V2.5 Program Requirements: The } \\
\text { Version } 2 \text { slab edge insulation } \\
\text { exemption remains only for Version } \\
\text { 2.5; therefore, up to } 25 \% \text { of the slab } \\
\text { edge may be uninsulated in } 2009 \\
\text { IECC Climate Zones } 4 \text { and } 5 .\end{array}$ & $\begin{array}{l}\text { (Mandatory) Thermal Enclosure } \\
\text { System Rater Checklist } \\
2.0 \text { Quality Installed Insulation. } \\
2.1 \text { Ceiling, wall, floor, and slab } \\
\text { insulation levels shall meet or } \\
\text { exceed } 2009 \text { IECC levels. }\end{array}$ \\
\hline $\begin{array}{l}\text { Residential } \\
\text { Energy } \\
\text { Efficiency }\end{array}$ & $\begin{array}{l}\text { Building } \\
\text { Thermal } \\
\text { Envelope }\end{array}$ & Prescriptive & $\begin{array}{l}402.2 \text { Specific } \\
\text { insulation } \\
\text { requirements. } \\
402.2 .7 \\
\text { Basement } \\
\text { walls. }\end{array}$ & $\begin{array}{l}\text { Walls associated with } \\
\text { conditioned basements shall be } \\
\text { insulated from the top of the } \\
\text { basement wall down to } 10 \text { feet } \\
\text { (3048 mm) below grade or to the } \\
\text { basement floor, whichever is } \\
\text { less. Walls associated with } \\
\text { unconditioned basements shall } \\
\text { meet this requirement untess the } \\
\text { floor overhead is insulated in }\end{array}$ & $\begin{array}{l}703.1 \text { Building Envelope (Optional, } \\
\text { Prescriptive path) } \\
\text { 703.1.2 The insulation installation is } \\
\text { graded by a third party and is in } \\
\text { accordance with Sections } 703.1 .2 .1, \\
\text { 703.1.2.2. 703.1.2.3, and/or 703.1.2.4 as } \\
\text { applicable. (Points not awarded in this } \\
\text { section if already awarded under Section } \\
\text { 703.1. } \\
\text { 703.1) }\end{array}$ & $\begin{array}{l}\text { EA 2: Insulation - Prescriptive Path } \\
\text { Prerequisite 2.1 Basic Insulation } \\
\text { (Mandatory.). Meet all the following } \\
\text { requirements: } \\
\text { a) Install insulation that meets or exceeds the } \\
\text { R-value requirements listed in Chapter } 4 \text { of } \\
\text { the } 2004 \text { International Energy Conservation } \\
\text { Code. }\end{array}$ & $\begin{array}{l}\text { Prescriptive Path: The building thermal } \\
\text { envelope must meet the following } \\
\text { requirements. Infiltration (ACH50): } 7 \text { in } \\
\text { CZ's 1-2, } 6 \text { in CZ's 3-4, } 5 \text { in CZ's 5-7, and } \\
4 \text { in CZ 8. And insulation levels must } \\
\text { meet or exceed the 2004 IRC, and a } \\
\text { completed Thermal Bypass Inspection } \\
\text { checklist must be performed. Envelope } \\
\text { leakage must be determined by a } \\
\text { RESNET- certified rater using a }\end{array}$ & $\begin{array}{l}\text { (Recommended) Thermal Enclosure } \\
\text { System Rater Checklist } \\
\text { 2.0 Quality Installed Insulation. } \\
\text { 2.1 Ceeiling, wall, floor, and slab } \\
\text { insulation levels shall meet or exceed } \\
\text { 2009 IECC levels. } \\
\text { V2.5 Program Requirements: The } \\
\text { Version 2 slab edge insulation } \\
\text { exemption remains only for Version } \\
\text { 2.5; therefore, up to 25\% of the slab }\end{array}$ & $\begin{array}{l}\text { (Mandatory) Thermal Enclosure } \\
\text { System Rater Checklist } \\
\text { 2.0 Quality Installed Insulation. } \\
2.1 \text { Ceiling, wall, floor, and slab } \\
\text { insulation levels shall meet or } \\
\text { exceed } 2009 \text { IECC levels. }\end{array}$ \\
\hline
\end{tabular}




\begin{tabular}{|c|c|c|c|c|c|c|c|c|c|}
\hline Category & Topic & $\begin{array}{l}\text { Requireme } \\
\text { nt category }\end{array}$ & $\begin{array}{c}\text { IECC } \\
\text { Requirement } \\
\text { Reference }\end{array}$ & IECC 2009 & ICC-700 & LEED for Homes & ES2 & ES2.5 & ES3 \\
\hline & & & & $\begin{array}{l}\text { accordance with Sections } \\
\text { 402.1.1 and 402.2.6. }\end{array}$ & $\begin{array}{l}\text { accordance with the following: } \\
\text { (1) Insulation uniformly fills each cavity } \\
\text { side-to-side and top-to-bottom, without } \\
\text { substantial gaps or voids around } \\
\text { obstructions (such as blocking or } \\
\text { bridging). } \\
\text { (8) Grade } 1 \text { insulation meets or exceeds } \\
\text { all requirements for Grade } 2 \text { insulation. } \\
\text { 703.1.2.3 Grade } 2 \text { insulation is in } \\
\text { accordance with the following: } \\
\text { (2) In conditioned basements or } \\
\text { crawlspaces the following apply: } \\
\text { (a) insulation is installed in complete } \\
\text { contact with the subfloor surfaces. } \\
\text { (b) floor insulation over vented or } \\
\text { ambient conditions is enclosed on six } \\
\text { sides. } \\
\text { (3) Floor insulation over unconditioned } \\
\text { basements is not required to be enclosed } \\
\text { on six sides. }\end{array}$ & & 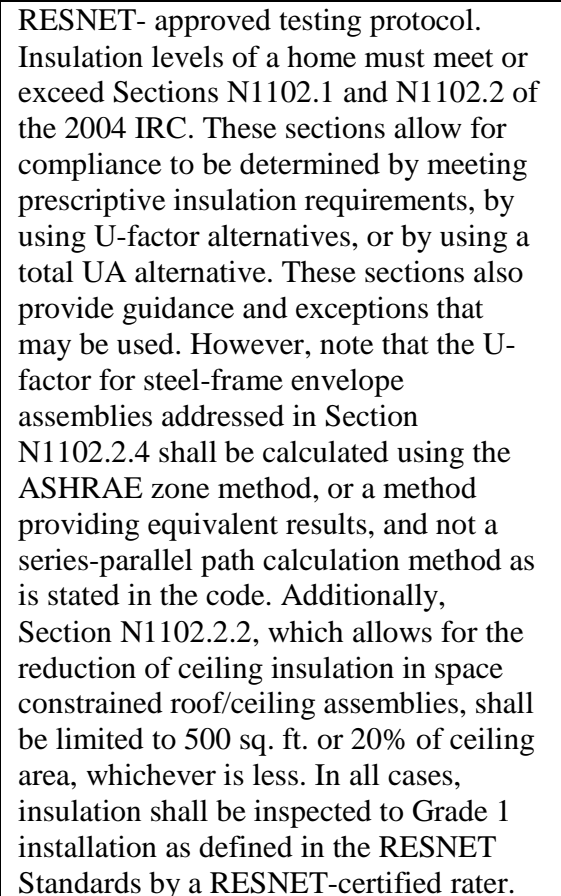 & $\begin{array}{l}\text { edge may be uninsulated in } 2009 \\
\text { IECC Climate Zones } 4 \text { and } 5 .\end{array}$ & \\
\hline $\begin{array}{l}\text { Residential } \\
\text { Energy } \\
\text { Efficiency }\end{array}$ & $\begin{array}{l}\text { Building } \\
\text { Thermal } \\
\text { Envelope }\end{array}$ & Prescriptive & $\begin{array}{l}\text { 402.2 Specific } \\
\text { insulation } \\
\text { requirements. } \\
\text { 402.2.8 Slab- } \\
\text { on-grade floors. }\end{array}$ & $\begin{array}{l}\text { Slab-on-grade floors with a floor } \\
\text { surface less than } 12 \text { inches ( } 305 \\
\text { mm) below grade shall be } \\
\text { insulated in accordance with } \\
\text { Table } 402.1 .1 \text {. The insulation } \\
\text { shall extend downward from the } \\
\text { top of the slab on the outside or } \\
\text { inside of the foundation wall. } \\
\text { Insulation located below grade } \\
\text { shall be extended the distance } \\
\text { provided in Table } 402.11 .1 \text { by any } \\
\text { combination of vertical } \\
\text { insulation, insulation extending } \\
\text { under the slab or insulation } \\
\text { extending out from the building. } \\
\text { Insulation extending away from } \\
\text { the building shall be protected by } \\
\text { pavement or by a minimum of } 10 \\
\text { inches (254 mm) of soil. The top } \\
\text { edge of the insulation installed } \\
\text { between the exterior wall and the } \\
\text { edge of the interior slab shall be } \\
\text { permitted to be cut at a } 45- \\
\text { degree (0.79 radd angle away } \\
\text { from the exterior wall. Slab-edge } \\
\text { insulation is not required in } \\
\text { jurisdictions designated by the } \\
\text { code official as having a very } \\
\text { heavy termite infestation. }\end{array}$ & - & $\begin{array}{l}\text { EA 2: Insulation - Prescriptive Path } \\
\text { Prerequisite 2.1 Basic Insulation } \\
\text { (Mandatory). Meet all the following } \\
\text { requirements: } \\
\text { a) Install insulation that meets or exceeds the } \\
\text { R-value requirements listed in Chapter } 4 \text { of } \\
\text { the } 2004 \text { International Energy Conservation } \\
\text { Code. }\end{array}$ & $\begin{array}{l}\text { (Mandatory) Thermal Bypass Inspection } \\
\text { Checklist } \\
1.0 \text { Overall Air Barrier and Thermal } \\
\text { Barrier Alignment. Insulation shall be } \\
\text { installed in full contact with sealed } \\
\text { interior and exterior air barrier except for } \\
\text { alternate to interior air barrier under item } \\
\text { no. } 2 \text { (Walls Adjoining Exterior Walls or } \\
\text { Unconditioned Spaced). Only at Climate } \\
\text { Zones } 4 \text { and Higher: } 1.4 \text { - Slab-edge } \\
\text { insulation (A maximum of } 25 \% \text { of the } \\
\text { slab edge may be uninsulated in Climate } \\
\text { Zones } 4 \text { and 5). } \\
\text { Prescriptive Path: The building thermal } \\
\text { envelope must meet the following } \\
\text { requirements. Infiltration (ACH5): } 7 \text { in } \\
\text { CZ's 1-2, 6 in CZ's } 3-4,5 \text { in CZ's 5-7, and } \\
4 \text { in CZ } 8 \text {. And insulation levels must } \\
\text { meet or exceed the 2004 IRC, and a } \\
\text { completed Thermal Bypass Inspection } \\
\text { checklist must be performed. Envelope } \\
\text { leakage must be determined by a } \\
\text { RESNET- certified rater using a } \\
\text { RESETE- approved testing protocol. } \\
\text { Insulation levels of a home must meet or } \\
\text { exceed Sections N1102.1 and N1102.2 of } \\
\text { the } 2004 \text { IRC. . These sections allow for } \\
\text { compliance to be determined by meeting } \\
\text { prescriptive insulation requirements, by } \\
\text { using U-factor alternatives, or by using a } \\
\text { total UA alternative. These sections also } \\
\text { provide guidance and exceptions that } \\
\text { may be used. However, note that the U- } \\
\text { factor for steel-frame envelope } \\
\text { assemblies addressed in Section } \\
\text { N1102.2.4 shall be calculated using the } \\
\text { ASHRAE zone method, or a method } \\
\text { providing equivalent results, and not a }\end{array}$ & $\begin{array}{l}\text { (Recommended) Thermal Enclosure } \\
\text { System Rater Checklist } \\
\text { 2.0 Quality Installed Insulation. } \\
2.1 \text { Ceiling, wall, floor, and slab } \\
\text { insultaition levels shall meet or exceed } \\
\text { 2009 IECC levels. Consistent with } \\
\text { the } 2009 \text { IECC, slab edge insulation } \\
\text { is only required for slab-on-grade } \\
\text { floors with a floor surface less than } \\
12 \text { inches below grade. Slab } \\
\text { insulation shall extend to the top of } \\
\text { the slab to provide a complete } \\
\text { thermal break. If the top edge of the } \\
\text { insulation is installed between the } \\
\text { exterior wall and the edge of the } \\
\text { interior slab, it shall be perrmitted to } \\
\text { be cut at a 45-degree angle away from } \\
\text { the exterior wall. } \\
\text { V2.5 Program Requirements: The } \\
\text { Version } 2 \text { slab edge insulation } \\
\text { exemption remains only for Version } \\
\text { 2.5; therefore, up to } 25 \% \text { of the slab } \\
\text { edge may be uninsulated in } 2009 \\
\text { IECC Climate Zones } 4 \text { and } 5 \text {. }\end{array}$ & $\begin{array}{l}\text { (Mandatory) Thermal Enclosure } \\
\text { System Rater Checklist } \\
\text { 2.0 Quality Installed Insulation. } \\
2.1 \text { Ceiling, wall, floor, and slab } \\
\text { insulation levels shall meet or } \\
\text { exceed 2009 IECC levels. } \\
\text { Consistent with the 2009 IECC, } \\
\text { slab edge insulation is only } \\
\text { required for slab-on-grade floors } \\
\text { with a floor surface less than } 12 \\
\text { inches below grade. Slab insulation } \\
\text { shall extend to the top of the slab to } \\
\text { provide a complete thermal break. } \\
\text { If the top edge of the insulation is } \\
\text { installed between the exterior wall } \\
\text { and the edge of the interior slab, it } \\
\text { shall be permitted to be cut tat a 45- } \\
\text { degree angle away from the } \\
\text { exterior wall. }\end{array}$ \\
\hline
\end{tabular}




\begin{tabular}{|c|c|c|c|c|c|c|c|c|c|}
\hline Category & Topic & $\begin{array}{l}\text { Requirem } \\
\text { nt category }\end{array}$ & $\begin{array}{c}\text { IECC } \\
\text { Requirement } \\
\text { Reference }\end{array}$ & IECC 2009 & ICC-700 & LEED for Homes & ES2 & ES2.5 & ES3 \\
\hline & & & & & & & $\begin{array}{l}\text { series-parallel path calculation method as } \\
\text { is stated in the code. Additionally, } \\
\text { Section N1102.2.2, which allows for the } \\
\text { reduction of ceiling insulation in space } \\
\text { constrained roof/ceiling assemblies, shall } \\
\text { be limited to } 500 \text { sq. ft. or } 20 \% \text { of ceiling } \\
\text { area, whichever is less. In all cases, } \\
\text { insulation shall be inspected to Grade } 1 \\
\text { installation as defined in the RESNET } \\
\text { Standards bv a RESNET-certified rater. }\end{array}$ & & \\
\hline $\begin{array}{l}\text { Residential } \\
\text { Energy } \\
\text { Efficiency }\end{array}$ & $\begin{array}{l}\text { Building } \\
\text { Thermal } \\
\text { Envelope }\end{array}$ & Prescriptive & $\begin{array}{l}402.2 \text { Specific } \\
\text { insulation } \\
\text { requirements. } \\
\text { 402.2.9 Crawl } \\
\text { space walls. }\end{array}$ & $\begin{array}{l}\text { As an alternative to insulating } \\
\text { floors over crawl spaces, crawl } \\
\text { space walls shall be permitted to } \\
\text { be insulated when the crawl } \\
\text { space is not vented to the } \\
\text { outside. Crawl space wall } \\
\text { insulation shall be permanently } \\
\text { fastened to the wall and extend } \\
\text { downward from the floor to the } \\
\text { finished grade level and then } \\
\text { vertically and/or horizontally for } \\
\text { at least an additional } 24 \text { inches } \\
\text { (610 mm). Exposed earth in } \\
\text { unvented crawl space } \\
\text { foundations shall be covered } \\
\text { with a continuous Class I vapor } \\
\text { retarder in accordance with the } \\
\text { International Building Code. All } \\
\text { joints of the vapor retarder shall } \\
\text { overlap by } 6 \text { inches ( (153 mm) } \\
\text { and be sealed or taped. The } \\
\text { edges of the vapor retarder shall } \\
\text { extend at least } 6 \text { inches ( (153 } \\
\text { mm) up the stem wall and shall } \\
\text { be attached to the stem wall. }\end{array}$ & $\begin{array}{l}\text { 701.4.3 Insulation and air sealing } \\
\text { (Mandatory) } \\
\text { (2) Crawlspace. Where insulated, } \\
\text { crawlspace wall insulation is permanently } \\
\text { attached to the walls. Exposed earth in } \\
\text { unvented crawlsplpaces is covered with } \\
\text { continuous vapor retarder with } \\
\text { overlapping joints that are taped or } \\
\text { masticed. }\end{array}$ & $\begin{array}{l}\text { EA 2: Insulation - Prescriptive Path } \\
\text { Prerequisite 2.1 Basic Insulation } \\
\text { (Mandatory). Meet all the following } \\
\text { requirements: } \\
\text { a) Install insulation that meets or exceeds the } \\
\text { R-value erequirements listed in Chapter } 4 \text { of } \\
\text { the } 2004 \text { International Energy Conservation } \\
\text { Code. }\end{array}$ & $\begin{array}{l}\text { Prescriptive Path. The building thermal } \\
\text { envelope must meet the following } \\
\text { requirements. Infiltration (ACH50): } 7 \text { in } \\
\text { CZ's 1-2, 6 in CZ's 3-4, } 5 \text { in CZ's 5-7, and } \\
4 \text { in CZ 8. And insulation levels must } \\
\text { meet or exceed the 2004 IRC, and a } \\
\text { completed Thermal Bypass Inspection } \\
\text { checklist must be performed. Envelope } \\
\text { leakage must be determined by a } \\
\text { RESNET- certified rater using a } \\
\text { RESNET- approved testing protocol. } \\
\text { Insulation levels of a home must meet or } \\
\text { exceed Sections N1102.1 and N1102.2 of } \\
\text { the 2004 IRC. Theses sections allow for } \\
\text { compliance to be determined by meeting } \\
\text { prescriptive insulation requirements, by } \\
\text { using U-factor alternatives, or by using a } \\
\text { total UA alternative. These sections also } \\
\text { provide guidance and exceptions that } \\
\text { may be used. However, note that the U- } \\
\text { factor for steel-frame envelope } \\
\text { assemblies addressed in Section } \\
\text { N1102.2.4 shall be calculated using the } \\
\text { ASHRAE zone method, or a method } \\
\text { providing equivalent results, and not a } \\
\text { series-parallel path calculation method as } \\
\text { is stated in the code. Additionallly, } \\
\text { Section N1102.2.2. which allows for the } \\
\text { reduction of ceiling insulation in space } \\
\text { constrained roof/ceiling assemblies, shall } \\
\text { be limited to } 500 \text { sq. ft. or 20\% of ceiling } \\
\text { area, whichever is less. In all cases, } \\
\text { insulation shall be inspected to Grade } 1 \\
\text { installation as defined in the RESNET } \\
\text { Standards by a RESNET-certified rater. }\end{array}$ & $\begin{array}{l}\text { (Recommended) Thermal Enclosure } \\
\text { System Rater Checklist } \\
\text { 2.0- Quality Installed Insulation. } \\
\text { 2.1 Cieiling, wall, floor, and slab } \\
\text { insulation levels shall meet or exceed } \\
2009 \text { IECC levels. } \\
\text { V2.5 Program Requirements: The } \\
\text { Version } 2 \text { slab edge insulation } \\
\text { exemption remains only for Version } \\
\text { 2.5; therefore, up to } 25 \% \text { of the slab } \\
\text { edge may be uninsulated in } 2009 \\
\text { IECC Climate Zones } 4 \text { and } 5 \text {. }\end{array}$ & $\begin{array}{l}\text { (Mandatory) Thermal Enclosure } \\
\text { System Rater Checklist } \\
2.0 \text { Quality Installed Insulation. } \\
2.1 \text { Ceiling, wall, floor, and slab } \\
\text { insulation levels shall meet or } \\
\text { exceed } 2009 \text { IECC levels. }\end{array}$ \\
\hline $\begin{array}{l}\text { Residential } \\
\text { Energy } \\
\text { Efficiency }\end{array}$ & $\begin{array}{l}\text { Building } \\
\text { Thermal } \\
\text { Envelope }\end{array}$ & Prescriptive & $\begin{array}{l}402.2 \text { Specific } \\
\text { insulation } \\
\text { requirements. } \\
402.2 .10 \\
\text { Masonry } \\
\text { veneer. }\end{array}$ & $\begin{array}{l}\text { Insulation shall not be required } \\
\text { on the horizontal portion of the } \\
\text { foundation that supports a } \\
\text { masonry veneer. }\end{array}$ & & $\begin{array}{l}\text { EA 2: Insulation - Prescriptive Path } \\
\text { Prerequisite 2.1 Basic Insulation } \\
\text { (Mandatory). Meet all the following } \\
\text { requirements: } \\
\text { a) Install insulation that meets or exceeds the } \\
\text { R-value requirements listed in Chapter } 4 \text { of } \\
\text { the } 2004 \text { International Energy Conservation } \\
\text { Code. }\end{array}$ & $\begin{array}{l}\text { Prescriptive Path: The building thermal } \\
\text { envelope must meet the following } \\
\text { requirements. Infiltration (ACH50): } 7 \text { in } \\
\text { CZ's 1-2, } 6 \text { in CZ's 3-4, } 5 \text { in CZ's } 5 \text {-7, and } \\
4 \text { in CZ 8. And insulation levels must } \\
\text { meet or exceed the 2004 IRC, and a } \\
\text { completed Thermal Bypass Inspection } \\
\text { checklist must be performed. Envelope } \\
\text { leakage must be determined by a } \\
\text { RESNET- certified rater using a } \\
\text { RESNET- approved testing protocol. } \\
\text { Insulation levels of a home must meet or } \\
\text { exceed Sections N1102.1 and N1102.2 of } \\
\text { the 2004 IRC. These sections allow for } \\
\text { compliance to be determined by meeting } \\
\text { prescriptive insulation requirements, by } \\
\text { using U-factor alternatives, or by suing a } \\
\text { total UA alternative. These sections also }\end{array}$ & $\begin{array}{l}\text { (Recommended) Thermal Enclosure } \\
\text { System Rater Checklist } \\
\text { 2.0 Quality Installed Insulation. } \\
\text { 2.1 Ceiling, wall, floor, and slab } \\
\text { insulatition levels shall meet or exceed } \\
\text { 2009 IECC levels. } \\
\text { V2.5 Program Requirements: The } \\
\text { Version } 2 \text { slab edge insulation } \\
\text { exemption remains only for Version } \\
\text { 2.5; therefore, up to to } 5 \% \text { of the slab } \\
\text { edge may be uninsulated in 2009 } \\
\text { IECC Climate Zones } 4 \text { and } 5 .\end{array}$ & $\begin{array}{l}\text { (Mandatory) Thermal Enclosure } \\
\text { System Rater Checklist } \\
2.0 \text { Quality Installed Insulation. } \\
2.1 \text { Ceiling, wall, floor, and slab } \\
\text { insulation levels shall meet or } \\
\text { exceed } 2009 \text { IECC levels. }\end{array}$ \\
\hline
\end{tabular}




\begin{tabular}{|c|c|c|c|c|c|c|c|c|c|}
\hline Category & Topic & $\begin{array}{l}\text { Requireme } \\
\text { nt category }\end{array}$ & $\begin{array}{c}\text { IECC } \\
\text { Requirement } \\
\text { Reference }\end{array}$ & IECC 2009 & ICC-700 & LEED for Homes & ES2 & ES2.5 & ES3 \\
\hline & & & & & & & $\begin{array}{l}\text { provide guidance and exceptions that } \\
\text { may be used. However, note that the U- } \\
\text { factor for steel-frame envelope } \\
\text { assemblies addressed in Section } \\
\text { N1102.2.4 shall be calculated using the } \\
\text { ASHRAE zone method, or a method } \\
\text { providing equivalent results, and not a } \\
\text { series-parallel path calculation method as } \\
\text { is stated in the code. Additionally, } \\
\text { Section N1102.2.2. which allows for the } \\
\text { reduction of ceiling insulation in space } \\
\text { constrained roof/ceiling assemblies, shall } \\
\text { be limited to } 500 \text { sq. ff. or } 20 \% \text { of ceiling } \\
\text { area, whichever is less. In all cases, } \\
\text { insulation shall be inspected to Grade } 1 \\
\text { installation as defined in the RESNET } \\
\text { Standards by a RESNET-certified rater. }\end{array}$ & & \\
\hline $\begin{array}{l}\text { Residential } \\
\text { Energy } \\
\text { Efficiency }\end{array}$ & $\begin{array}{l}\text { Building } \\
\text { Thermal } \\
\text { Envelope }\end{array}$ & Prescriptive & $\begin{array}{l}\text { 402.2 Specific } \\
\text { insulation } \\
\text { requirements. } \\
402.2 .11 \\
\text { Thermally } \\
\text { isolated } \\
\text { sunroom } \\
\text { insulation. }\end{array}$ & $\begin{array}{l}\text { The minimum ceiling insulation } \\
\text { R-values shall be R-19 in Zones } \\
1 \text { through } 4 \text { and R-24 in Zones } 5 \\
\text { through } 8 \text {. The minimum wall R- } \\
\text { value shall be R-13 in all zones. } \\
\text { New walls(s) separating a } \\
\text { sunroom from conditioned space } \\
\text { shall meet the building thermal } \\
\text { envelope requirements. }\end{array}$ & 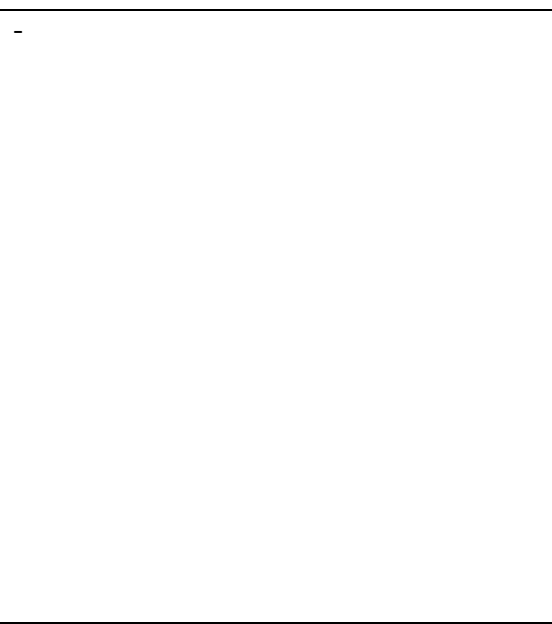 & $\begin{array}{l}\text { EA 2: Insulation - Prescriptive Path } \\
\text { Prerequisite 2.1 Basic Insulation } \\
\text { (Mandatory). Meet all the following } \\
\text { requirements: } \\
\text { a) Install insulation that meets or exceeds the } \\
\text { R-value requirements listed in Chapter } 4 \text { of } \\
\text { the } 2004 \text { International Energy Conservation } \\
\text { Code. }\end{array}$ & $\begin{array}{l}\text { (Mandatory)Thermal Bypass Inspection } \\
\text { Checklist } \\
\text { 1.0 Overall Air Barrier and Thermal } \\
\text { Barrier Alignment. Insulation shall be } \\
\text { installed in full contact with sealed } \\
\text { interior and exterior air barrier except for } \\
\text { alternate to interior air barrier under item } \\
\text { no. } 2 \text { (Walls Adjoining Exterior Walls or } \\
\text { Unconditioned Spaces). } \\
\text { 2.0 Walls Adjoining Exterior Walls or } \\
\text { Unconditioned Spaces. Fully insulated } \\
\text { wall aligned with air barrier at both } \\
\text { interior and exterior, OR Alternate for } \\
\text { Climate Zones } 1 \text { thru 3, sealed exterior } \\
\text { air barrier aligned with RESNET Grade } 1 \\
\text { insulation fully supported. Continuous } \\
\text { top and bottom plates or sealed blocking. }\end{array}$ & $\begin{array}{l}\text { (Recommended) Thermal Enclosure } \\
\text { System Rater Checklist } \\
2.0 \text { Quality Installed Insulation. } \\
\text { 2.1 Ceiling, wall, floor, and slab } \\
\text { insulation levels shall meet or exceed } \\
2009 \text { IECC levels. } \\
\text { V2.5 Program Requirements: The } \\
\text { Version } 2 \text { slab edge insulation } \\
\text { exemption remains only for Version } \\
\text { 2.5; therefore, up to } 25 \% \text { of the slab } \\
\text { edge may be uninsulated in } 2009 \\
\text { IECC Climate Zones } 4 \text { and 5. }\end{array}$ & $\begin{array}{l}\text { (Mandatory) Thermal Enclosure } \\
\text { System Rater Checklist } \\
2.0 \text { Quality Installed Insulation. } \\
\text { 2.1 Ceiling, wall, floor, and slab } \\
\text { insulation levels shall meet or } \\
\text { exceed 2009 IECC levels. }\end{array}$ \\
\hline $\begin{array}{l}\text { Residential } \\
\text { Energy } \\
\text { Efficiency }\end{array}$ & $\begin{array}{l}\text { Building } \\
\text { Thermal } \\
\text { Envelope }\end{array}$ & Prescriptive & $\begin{array}{l}402.3 \\
\text { Fenestration. } \\
\text { 402.3.1 U- } \\
\text { factor. }\end{array}$ & $\begin{array}{l}\text { An area-weighted average of } \\
\text { fenestration products shall be } \\
\text { permitted to satisfy the U-factor } \\
\text { requirements. }\end{array}$ & $\begin{array}{l}\text { 701.4.4 Fenestration (Mandatory) } \\
\text { 701.4.4.1 NFRC-certified U-factor and } \\
\text { SHGC windows, exterior doors, } \\
\text { skylights, and tubular daylighting devices } \\
\text { (TDDs) are in accordance with ENERGY } \\
\text { STAR, or equivalent, or Table 701.4.4.1. } \\
\text { Decorative fenestration elements with a } \\
\text { maximum area of } 15 \text { square feet or } 10 \\
\text { percent of the total glazing area, } \\
\text { whichever is less, are not required to } \\
\text { comply with this practice. } \\
\text { 703.3 Fenestration (Optional, } \\
\text { Prescripive path) } \\
\text { 703.3.1 The NFRC-certified (or } \\
\text { equivalent) U-factor and SHGC for } \\
\text { windows...are in accordance with Table } \\
\text { 703.3.1(a) or (b)... }\end{array}$ & & $\begin{array}{l}\text { Prescriptive Path: Windows must meet or } \\
\text { exceed version } 4.0 \text { of the Energy Star } \\
\text { Program Requirements for Residential } \\
\text { Windows, Doors, and Skylights } \\
\text { (additional requirements for CZ } 2 \text { \& 4). }\end{array}$ & $\begin{array}{l}\text { (Recommended) Thermal Enclosure } \\
\text { System Rater Checklist } \\
\text { 1.0 High-Performance Fenestration } \\
1.1 \text { Prescriptive Path: Fenestration } \\
\text { shall meet or exceed ENERGY } \\
\text { STAR* requirements. } \\
1.2 \text { Performance Path: Fenestration } \\
\text { shall meet or exceed 2009 IECC } \\
\text { requirements. } \\
\text { *ENERGY STAR Program } \\
\text { Requirements for Residential } \\
\text { Windows, Doors, and Skylights - } \\
\text { Version 5.0 as outlined at } \\
\text { www.energystar.gov/windows. }\end{array}$ & $\begin{array}{l}\text { (Mandatory) Thermal Enclosure } \\
\text { System Rater Checklist } \\
\text { 1.0 High-Performance Fenestration } \\
\text { 1.1 Prescriptive Path: Fenestration } \\
\text { shall meet or exceed ENERGY } \\
\text { STAR* requirements. } \\
\text { 1.2 Performance Path: Fenestration } \\
\text { shall meet or exceed 2009 IECC } \\
\text { requirements. } \\
\text { *ENERGY STAR Program } \\
\text { Requirements for Residential } \\
\text { Windows, Doors, and Skylights - } \\
\text { Version 5.0 as outlined at } \\
\text { www.energystar.gov/windows. }\end{array}$ \\
\hline $\begin{array}{l}\text { Residential } \\
\text { Energy } \\
\text { Efficiency }\end{array}$ & $\begin{array}{l}\text { Building } \\
\text { Thermal } \\
\text { Envelope }\end{array}$ & Prescriptive & $\begin{array}{l}402.3 \\
\text { Fenestration. } \\
\text { 402.3.2- } \\
\text { 402.3.3. }\end{array}$ & $\begin{array}{l}\text { 402.3.2. Glazed fenestration } \\
\text { SHGC. An area-weighted } \\
\text { average of fenestration products } \\
\text { more than } 50 \text { percent glazed } \\
\text { shall be permitted to satisfy the } \\
\text { SHGC requirements. } \\
\text { 402.3.3 Glazed fenestration } \\
\text { exemption. Up to } 15 \text { square feet } \\
\text { (1.4m2) of glazed fenestration } \\
\text { per dwelling unit shall be } \\
\text { permitted to be exempt from U- } \\
\text { factor and SHGC requirements }\end{array}$ & $\begin{array}{l}\text { 701.4.4.4.1 (Mandatory) } \\
\text {..Decorative fenestration elements with a } \\
\text { maximum area of } 15 \text { square feet or } 10 \\
\text { percent of the total glazing area, } \\
\text { whichever is less, are not required to } \\
\text { comply with this practice. } \\
\text { 703.3.1. (Optional)...Decorative } \\
\text { fenestration elements with a maximum } \\
\text { area of } 15 \text { square feet or } 10 \text { percent of the } \\
\text { total glazing area, whichever is less, are } \\
\text { not required to comply with this practice. }\end{array}$ & $\begin{array}{l}\text { EA 4: Windows - Prescriptive Path } \\
\text { Note: Up to } 0.75 \% \text { of the window-to-floor } \\
\text { area may be used for decorative glass or } \\
\text { skylight area that does not meet the U-factor } \\
\text { and SHGC requirements above. }\end{array}$ & $\begin{array}{l}\text { Prescriptive Path: Windows must meet or } \\
\text { exceed version } 4.0 \text { of the Energy Star } \\
\text { Program Requirements for Residential } \\
\text { Windows, Doors, and fkylights } \\
\text { (additional requirements for CZ } 2 \& 4 \text { ). } \\
\text { Refer to the county-level BOPs on EPA's } \\
\text { website for the specific window } \\
\text { performance levels required in each } \\
\text { county of the country. }\end{array}$ & $\begin{array}{l}\text { (Recommended) Thermal Enclosure } \\
\text { System Rater Checklist } \\
\text { 1.0 High-Performance Fenestration } \\
\text { 1.1 Prescriptive Path: Fenestration } \\
\text { shall meet or exceed ENERGY } \\
\text { STAR* requirements. } \\
\text { 1.2 Performance Path: Fenestration } \\
\text { shall meet or exceed 2009 IECC } \\
\text { requirements. } \\
\text { *ENERGY STAR Program } \\
\text { Requirements for Residential }\end{array}$ & $\begin{array}{l}\text { (Mandatory) Thermal Enclosure } \\
\text { System Rater Checklist } \\
1.0 \text { High-Performance Fenestration } \\
1.1 \text { Prescriptive Path: Fenestration } \\
\text { shall meet or exceed ENERGY } \\
\text { STR** requirements. } \\
\text { 1.2 Performance Path: Fenestration } \\
\text { shall meet or exceed 2009 IECC } \\
\text { requirements. } \\
\text { *ENERGY STAR Program } \\
\text { Requirements for Residential }\end{array}$ \\
\hline
\end{tabular}




\begin{tabular}{|c|c|c|c|c|c|c|c|c|c|}
\hline Category & Topic & $\begin{array}{l}\text { Requireme } \\
\text { nt category }\end{array}$ & $\begin{array}{c}\text { IECC } \\
\text { Requirement } \\
\text { Reference }\end{array}$ & IECC 2009 & ICC-700 & LEED for Homes & ES2 & ES2.5 & ES3 \\
\hline & & & & $\begin{array}{l}\text { in Section 402.1.1. This } \\
\text { exemption shall not apply to the } \\
\text { U-factor alternative approach in } \\
\text { Section 402.1.3 and the Total } \\
\text { UA alternative in Section } \\
\text { 402.1.4. }\end{array}$ & & & & $\begin{array}{l}\text { Windows, Doors, and Skylights - } \\
\text { Version } 5.0 \text { as outlined at } \\
\text { www.enengystar.gov/windows. }\end{array}$ & $\begin{array}{l}\text { Windows, Doors, and Skylights - } \\
\text { Version } 5.0 \text { as outlined at } \\
\text { www.energystar.gov/windows. }\end{array}$ \\
\hline $\begin{array}{l}\text { Residential } \\
\text { Energy } \\
\text { Efficiency }\end{array}$ & $\begin{array}{l}\text { Building } \\
\text { Thermal } \\
\text { Envelope }\end{array}$ & Prescriptive & $\begin{array}{l}402.3 \\
\text { Fenestration. } \\
\text { 402.3.4 Opaque } \\
\text { door } \\
\text { exemption. }\end{array}$ & $\begin{array}{l}\text { One side-hinged opaque door } \\
\text { assembly up to } 24 \text { square feet } \\
\text { (2.22 } \mathrm{m} 2 \text { 2) in area is exempted } \\
\text { from the U-factor requirement in } \\
\text { Section 402.1.1. This exemption } \\
\text { shall not apply to the U-factor } \\
\text { alternative approach in Section } \\
\text { 402.1.3 and the total UA } \\
\text { alternative in Section 402.1.4. }\end{array}$ & & & 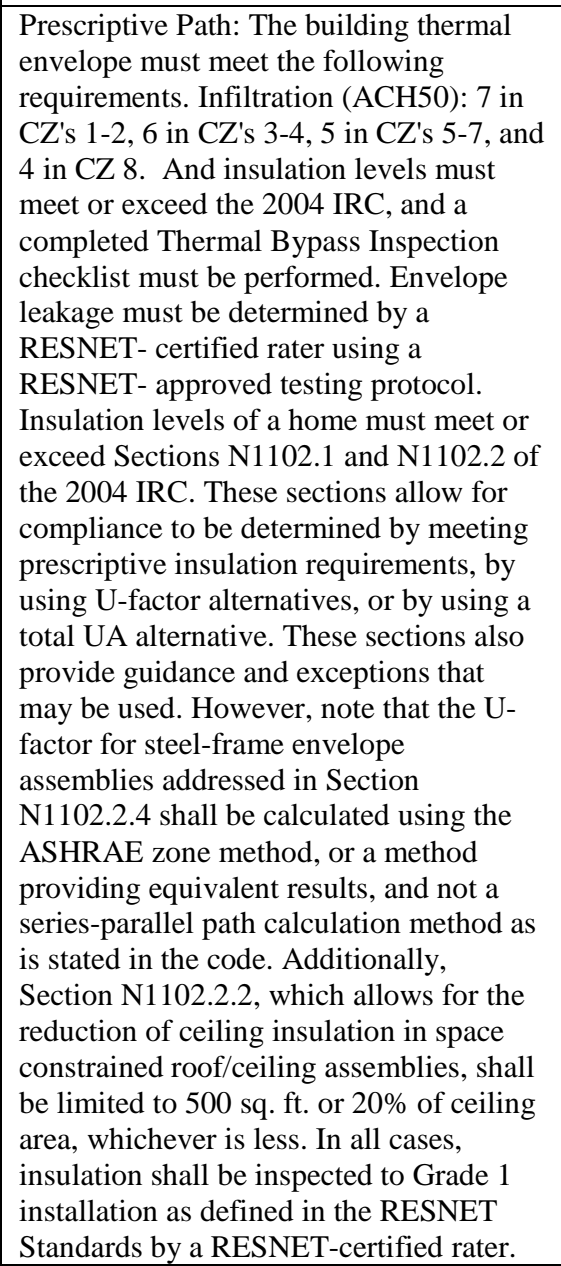 & $\begin{array}{l}\text { (Recommended) Thermal Enclosure } \\
\text { System Rater Checklist } \\
\text { 1.0 High-Performance Fenestration } \\
\text { 1.1 Prescriptive Path: Fenestration } \\
\text { hhall meet or exceed ENERGY } \\
\text { STAR* equirements. } \\
\text { 1.2 Performance Path : Fenestration } \\
\text { shall meet or exceed 2009 IECC } \\
\text { requirements. } \\
\text { *ENERGY STAR Program } \\
\text { Requirements for Residential } \\
\text { Windows, Doors, and Skylights - } \\
\text { Version 5.0 as outlined at } \\
\text { www.energystar.gov/windows. }\end{array}$ & $\begin{array}{l}\text { (Mandatory) Thermal Enclosure } \\
\text { System Rater Checklist } \\
\text { 1.0 High-Performance Fenestration } \\
\text { 1.1 Prescriptive Path: Fenestration } \\
\text { shall meet or exceed ENERGY } \\
\text { STAR* requirements. } \\
\text { 1.2 Performance Path : } \\
\text { Fenestration shall meet or exceed } \\
\text { 2009 IECC requirements. } \\
\\
\text { *ENERGY STAR Program } \\
\text { Requirements for Residential } \\
\text { Windows, Doors, and Skylights - } \\
\text { Version 5.0 as outlined at } \\
\text { www.energystar.gov/windows. }\end{array}$ \\
\hline $\begin{array}{l}\text { Residential } \\
\text { Energy } \\
\text { Efficiency }\end{array}$ & $\begin{array}{l}\text { Building } \\
\text { Thermal } \\
\text { Envelope }\end{array}$ & $\begin{array}{l}\text { Prescriptive } \\
\end{array}$ & $\begin{array}{l}402.3 \\
\text { Fenestration. } \\
402.3 .5 \\
\text { Thermally } \\
\text { isolated } \\
\text { sunroom U- } \\
\text { factor. }\end{array}$ & $\begin{array}{l}\text { For Zones } 4 \text { through } 8 \text {, the } \\
\text { maximum fenestration U-factor } \\
\text { shall be 0.50 and the maximumm } \\
\text { skylight U-factor shall be } 0.75 \text {. } \\
\text { New windows and doors } \\
\text { separating the sunroom from } \\
\text { conditioned space shall meet the } \\
\text { building thermal envelope } \\
\text { requirements. }\end{array}$ & & & \begin{tabular}{|c|}
- \\
\end{tabular} & $\begin{array}{l}\text { (Recommended) Thermal Enclosure } \\
\text { System Rater Checklist } \\
\text { 1.0 High-Performance Fenestration } \\
\text { 1.1 Prescriptive Path: Fenestration } \\
\text { shall meet or exceed ENERGY } \\
\text { STAR* requirements. } \\
\text { 1.2 Performance Path: Fenestration } \\
\text { shall meet or exceed 2009 IECC } \\
\text { requirements. } \\
\text { *ENERGY STAR Program } \\
\text { Requirements for Residential } \\
\text { Windows, Doors, and Skylights - } \\
\text { Version 5. } 0 \text { as outlined at } \\
\text { www.energystar.gov/windows. }\end{array}$ & $\begin{array}{l}\text { (Mandatory) Thermal Enclosure } \\
\text { System Rater Checklist } \\
\text { 1.0 High-Performance Fenestration } \\
\text { 1.1 Prescriptive Path: Fenestration } \\
\text { shall meet or exceed ENERGY } \\
\text { STAR* requirements. } \\
1 \text { 1.2 Performance Path: Fenestration } \\
\text { shall meet or exceed 2009 IECC } \\
\text { requirements. } \\
\text { *ENERGY STAR Program } \\
\text { Requirements for Residential } \\
\text { Windows, Doors, and Skylights - } \\
\text { Version 5.0 as outlined at } \\
\text { www.energystar.gov/windows. }\end{array}$ \\
\hline $\begin{array}{l}\text { Residential } \\
\text { Energy } \\
\text { Efficiency }\end{array}$ & $\begin{array}{l}\text { Building } \\
\text { Thermal } \\
\text { Envelope }\end{array}$ & $\begin{array}{l}\text { Prescriptive } \\
\end{array}$ & $\begin{array}{l}402.3 \\
\text { Fenestration. } \\
402.3 .6 \\
\text { Replacement } \\
\text { fenestration. }\end{array}$ & $\begin{array}{l}\text { Where some or all of an existing } \\
\text { fenestration unit is replaced with } \\
\text { a new fenestration product, } \\
\text { including sash and glazing, the } \\
\text { replacement fenestration unit } \\
\text { shall meet the epplicable } \\
\text { requirements for U-factor and }\end{array}$ & $\begin{array}{l}703.3 \text { Fenestration (Optional, } \\
\text { Prescriptive Path) } \\
\text { Renovation Note. Section } 703.3 .1 \text { applies } \\
\text { only to the replacement of existing } \\
\text { windows. Points available on the basis of } \\
\text { a ratio of new window area to total } \\
\text { window area (new window area/total }\end{array}$ & & & $\begin{array}{l}\text { (Recommended) Thermal Enclosure } \\
\text { System Rater Checklist } \\
1 \text { 1. Hight-Performance Fenestration } \\
1.1 \text { Prescriptive Path: Fenestration } \\
\text { shall meet or exceed ENERGY } \\
\text { STAR* requirements. } \\
\text { 1.2 Performance Path: Fenestration }\end{array}$ & $\begin{array}{l}\text { (Mandatory) Thermal Enclosure } \\
\text { System Rater Checklist } \\
\text { 1.0 High-Performance Fenestration } \\
\text { 1.1 Prescriptive Path: Fenestration } \\
\text { shall meet or exceed ENERGY } \\
\text { STAR* requirements. } \\
\text { 1.2 Performance Path: Fenestration }\end{array}$ \\
\hline
\end{tabular}




\begin{tabular}{|c|c|c|c|c|c|c|c|c|c|}
\hline Category & Topic & $\begin{array}{l}\text { Requireme } \\
\text { nt category }\end{array}$ & $\begin{array}{c}\text { IECC } \\
\text { Requirement } \\
\text { Reference } \\
\end{array}$ & IECC 2009 & ICC-700 & LEED for Homes & ES2 & ES2.5 & ES3 \\
\hline & & & & SHGC in Table 402.1.1. & window area). & & & $\begin{array}{l}\text { shall meet or exceed } 2009 \text { IECC } \\
\text { requirements. } \\
\text { *ENERGY STAR Program } \\
\text { *equirements for Residential } \\
\text { Rindows, Doors, and Skylights - } \\
\text { Version 5.0 as outlined at } \\
\text { www.energystar.gov/windows. } \\
\end{array}$ & $\begin{array}{l}\text { shall meet or exceed } 2009 \text { IECC } \\
\text { requirements. } \\
\text { *ENERGY STAR Program } \\
\text { Requirements for Residential } \\
\text { Windows, Doors, and Skylights - } \\
\text { Version 5.0 as outlined at } \\
\text { www.energystar.gov/windows. } \\
\end{array}$ \\
\hline $\begin{array}{l}\text { Residential } \\
\text { Energy } \\
\text { Efficiency }\end{array}$ & $\begin{array}{l}\text { Building } \\
\text { Thermal } \\
\text { Envelope }\end{array}$ & Mandatory & $\begin{array}{l}\text { 402.4 Air } \\
\text { leakage. } \\
\text { 402.4.1 } \\
\text { Building } \\
\text { thermal } \\
\text { envelope. }\end{array}$ & $\begin{array}{l}\text { The building thermal envelope } \\
\text { shall be durably sealed to limit } \\
\text { infiltration. The sealing methods } \\
\text { between dissimilar materials } \\
\text { shall allow for differential } \\
\text { expansion and contraction. The } \\
\text { following shall be caulked, } \\
\text { gasketed, weatherstripped or } \\
\text { otherwise sealed with an air } \\
\text { barrier material, wuitable film or } \\
\text { solid material: }\end{array}$ & & & & & \\
\hline $\begin{array}{c}\text { Residential } \\
\text { Energy } \\
\text { Efficiency }\end{array}$ & $\begin{array}{l}\text { Building } \\
\text { Thermal } \\
\text { Envelope }\end{array}$ & Mandatory & $\begin{array}{l}\text { 402.4 Air } \\
\text { leakage. } \\
\text { 402.4.1 } \\
\text { Building } \\
\text { thermal } \\
\text { envelope. (1) }\end{array}$ & $\begin{array}{l}\text { The following shall be caulked, } \\
\text { gasketed, weatherstripped or } \\
\text { otherwise sealed with an air } \\
\text { barrier material, suitable film or } \\
\text { solid material: } \\
\text { 1. All joints, seams and } \\
\text { penetrations. }\end{array}$ & $\begin{array}{l}\text { 701.4.3. Insulation and air sealing } \\
\text { (Mandatory.) } \\
\text { 701.4.3.1 General. Insulation and air } \\
\text { sealing is in accordance with the } \\
\text { following: } \\
\text { (1) Insulation. Insulation is installed in } \\
\text { accordance with the manufacturer's } \\
\text { instructions or local code, as applicable. } \\
\text { (2) Shafts (duct shaft, piping } \\
\text { shaft/penetrations, flue shaft). Openings } \\
\text { to unconditioned space are fully sealed } \\
\text { with solid blocking of flashing and any } \\
\text { remaining gaps are sealed with caulk or } \\
\text { foam. Fire-rated collars and caulking are } \\
\text { installed where required. } \\
\text { 703.2.1.2 Air Barriers (Optional, } \\
\text { Prescriptive path). Air barrier is installed } \\
\text { at any exterior edge of insulation at } \\
\text { floors, foundations, and crawlspaces } \\
\text { including insulated floors above garages } \\
\text { and cantilevered floors. }\end{array}$ & & 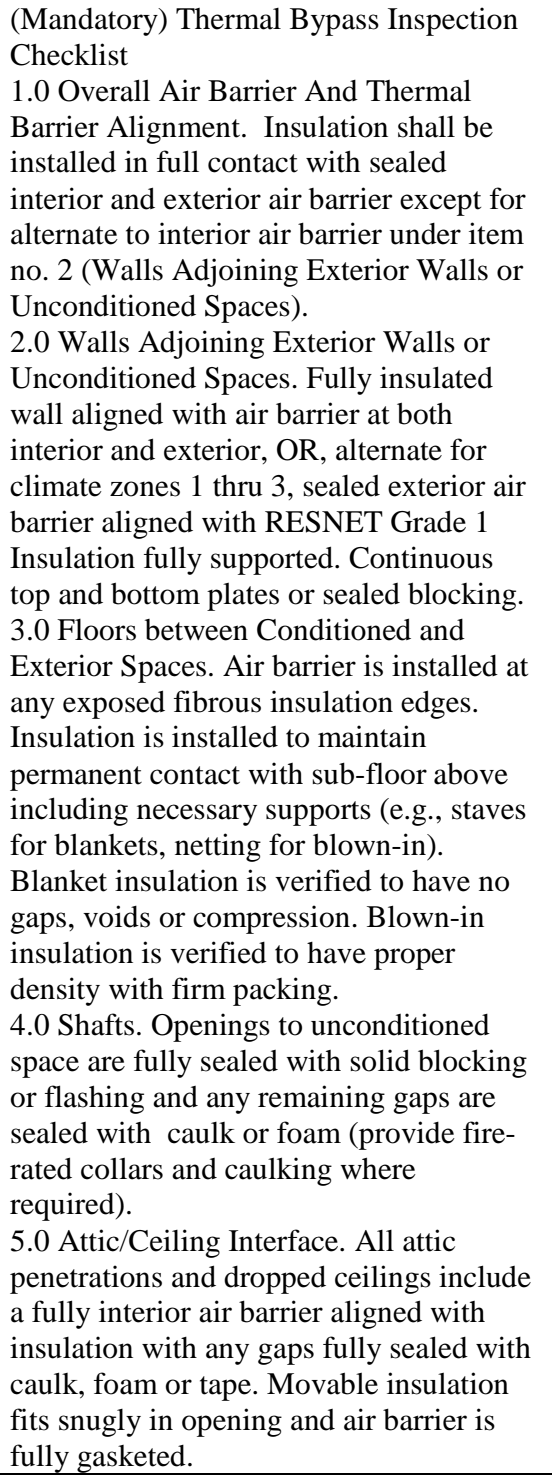 & $\begin{array}{l}\text { (Mandatory) Thermal Enclosure } \\
\text { System Rater Checklist } \\
5.0 \text { Air Sealing } \\
5.1 \text { Penetrations to unconditioned } \\
\text { space fully sealed with solid blocking } \\
\text { or flashing as needed and gaps sealed } \\
\text { with caulk or foam. } \\
5.2 \text { Cracks in the building envelope } \\
\text { fully sealed } \\
5.3 \text { Other openings }\end{array}$ & $\begin{array}{l}\text { (Mandatory) Thermal Enclosure } \\
\text { System Rater Checklist } \\
5.0 \text { Air Sealing } \\
5.1 \text { Penetrations to unconditioned } \\
\text { space fully sealed with solid } \\
\text { blocking or flashing as needed and } \\
\text { gaps sealed with caulk or foam. } \\
5.2 \text { Cracks in the building envelope } \\
\text { fully sealed } \\
5.3 \text { Other openings }\end{array}$ \\
\hline $\begin{array}{l}\text { Residential } \\
\text { Energy } \\
\text { Efficiency }\end{array}$ & $\begin{array}{l}\text { Building } \\
\text { Thermal } \\
\text { Envelope }\end{array}$ & Mandatory & $\begin{array}{l}\text { 402.4 Air } \\
\text { leakage. } \\
\text { 402.4.1 }\end{array}$ & $\begin{array}{l}\text { The following shall be caulked, } \\
\text { gasketed, weathertsirpped or } \\
\text { otherwise sealed with an air }\end{array}$ & $\begin{array}{l}\text { 701.4.3 Insulation and air sealing } \\
\text { (Mandatory). } \\
\text { 701.4.3.3 Walls }\end{array}$ & & $\begin{array}{l}\text { (Mandatory) Thermal Bypass Inspection } \\
\text { Checklist } \\
1.0 \text { Overall Air Barrier And Thermal }\end{array}$ & $\begin{array}{l}\text { (Mandatory) Thermal Enclosure } \\
\text { System Rater Checklist } \\
5.0 \text { Air Sealing }\end{array}$ & $\begin{array}{l}\text { (Mandatory) Thermal Enclosure } \\
\text { System Rater Checklist } \\
5.0 \text { Air Sealing }\end{array}$ \\
\hline
\end{tabular}




\begin{tabular}{|c|c|c|c|c|c|c|c|c|c|}
\hline Category & Topic & $\begin{array}{l}\text { Requireme } \\
\text { nt category }\end{array}$ & $\begin{array}{c}\text { IECC } \\
\text { Requirement } \\
\text { Reference } \\
\end{array}$ & IECC 2009 & ICC-700 & LEED for Homes & ES2 & ES2.5 & ES3 \\
\hline & & & $\begin{array}{l}\text { Building } \\
\text { thermal } \\
\text { envelope. (2) }\end{array}$ & $\begin{array}{l}\text { barrier material, suitable film or } \\
\text { solid material: } \\
\text { 2. Site-built windows, doors and } \\
\text { skylights. }\end{array}$ & $\begin{array}{l}\text { (1) Windows and doors. Caulking, } \\
\text { gasketing, adhesive flashing tape, foam } \\
\text { sealant, or weatherstripping is installed } \\
\text { forming a complete air barrier. } \\
\text { (4) Skylights and knee walls. Skylight } \\
\text { shafts and knee walls are insulated to the } \\
\text { same level as the exterior walls. } \\
\text { 703.2 Insulation and air sealing } \\
\text { (Optional, Prescriptive path). } \\
\text { 703.2.1.3. Walls } \\
\text { (4) Skylight shafts and knee walls are air } \\
\text { sealed. Insulation on attic knee walls and } \\
\text { skylight shafts are physically supported } \\
\text { by stapling in place, netting, or using } \\
\text { other mechanical attachment. }\end{array}$ & & $\begin{array}{l}\text { Barrier Alignment. Insulation shall be } \\
\text { installed in full contact with sealed } \\
\text { interior and exterior air barrier except for } \\
\text { alternate to interior air barrier under item } \\
\text { no. } 2 \text { (Walls Adjoining Exterior Walls or } \\
\text { Unconditioned Spaces). }\end{array}$ & $\begin{array}{l}5.2 \text { Cracks in the building envelope } \\
\text { fully sealed. } \\
5.2 .4 \text { Rough Openings around } \\
\text { windows and exterior doors sealed } \\
\text { with caulk or foam. } \\
5.3 \text { Other Openings }\end{array}$ & $\begin{array}{l}5.2 \text { Cracks in the building envelope } \\
\text { fully sealed. } \\
5.2 .4 \text { Rough Openings around } \\
\text { windows and exterior doors sealed } \\
\text { with caulk or foam. } \\
5.3 \text { Other Openings }\end{array}$ \\
\hline $\begin{array}{l}\text { Residential } \\
\text { Energy } \\
\text { Efficiency }\end{array}$ & $\begin{array}{l}\text { Building } \\
\text { Thermal } \\
\text { Envelope }\end{array}$ & Mandatory & $\begin{array}{l}\text { 402.4 Air } \\
\text { leakage. } \\
402.4 .1 \\
\text { Building } \\
\text { thermal } \\
\text { envelope. (3) }\end{array}$ & $\begin{array}{l}\text { The following shall be caulked, } \\
\text { gasketed, weatherstripped or } \\
\text { otherwise sealed with an air } \\
\text { barrier material, suitable film or } \\
\text { solid material: } \\
\text { 3. Openings between window } \\
\text { and door assemblies and their } \\
\text { respective jambs and framing. }\end{array}$ & $\begin{array}{l}\text { 701.4.3 Insulation and air sealing } \\
\text { (Mandatory). } \\
\text { 701.4.3.3 Walls } \\
\text { (1) Windows and doors. Caulking, } \\
\text { gasketing, adhesive flashing tape, foam } \\
\text { sealant, or weatherstripping is installed } \\
\text { forming a complete air barrier. }\end{array}$ & & 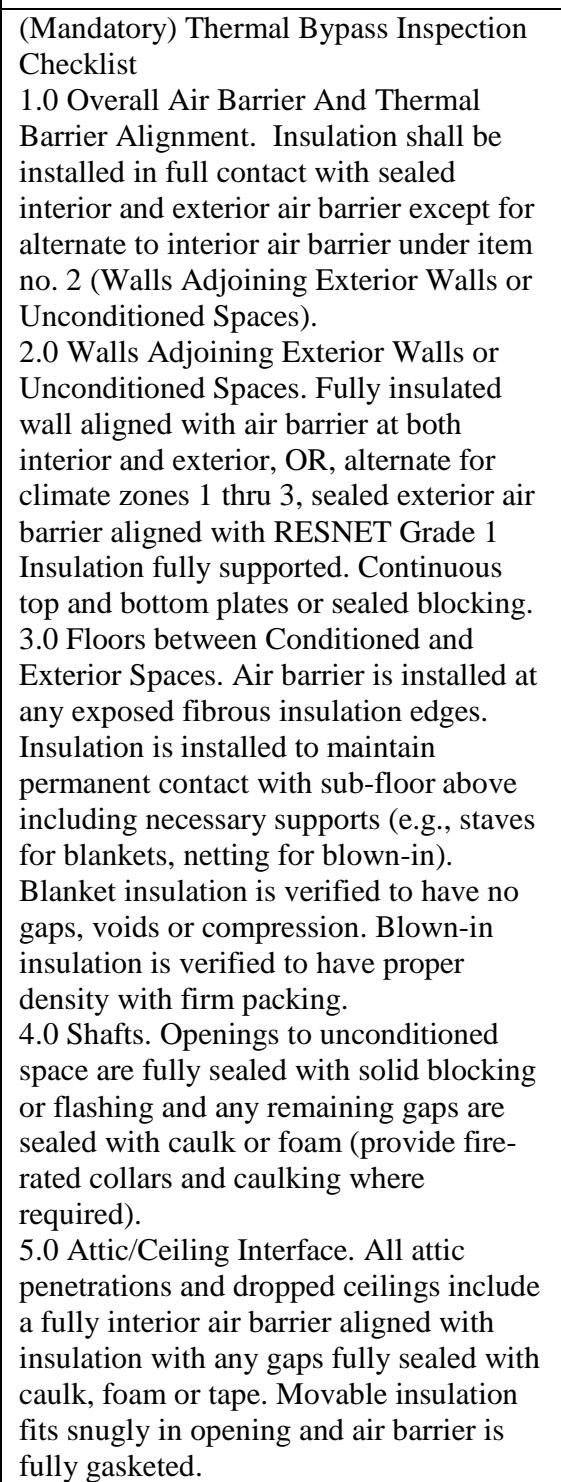 & $\begin{array}{l}\text { (Mandatory) Thermal Enclosure } \\
\text { System Rater Checklist } \\
\text { 5.0 Air Sealing } \\
5.2 \text { Cracks in the building envelope } \\
\text { fully sealed. } \\
\text { 5.2.4 Rough Openings around } \\
\text { windows and exterior doors sealed } \\
\text { with caulk or foam. } \\
5.3 \text { Other Openings }\end{array}$ & \begin{tabular}{|l} 
(Mandatory) Thermal Enclosure \\
System Rater Checklist \\
5.0 Air Sealing \\
5.2 Cracks in the building envelope \\
fully sealed. \\
5.2 .4 Rough Openings around \\
windows and exterior doors sealed \\
with caulk or foam. \\
5.3 Other Openings
\end{tabular} \\
\hline $\begin{array}{l}\text { Residential } \\
\text { Energy } \\
\text { Efficiency }\end{array}$ & $\begin{array}{l}\text { Building } \\
\text { Thermal } \\
\text { Envelope }\end{array}$ & Mandatory & $\begin{array}{l}\text { 402.4 Air } \\
\text { leakage. } \\
\text { 402.4.1 } \\
\text { Building } \\
\text { thermal } \\
\text { envelope. (4) }\end{array}$ & $\begin{array}{l}\text { The following shall be caulked, } \\
\text { gasketed, weatherstripped or } \\
\text { otherwise sealed with an air } \\
\text { barrier material, suitable film or } \\
\text { solid material: } \\
\text { 4. Utility penetrations. }\end{array}$ & $\begin{array}{l}\text { 701.4.3 Insulation and air sealing } \\
\text { (Mandatory). } \\
\text { 701.4.3.3 Walls } \\
\text { (1) Windows and doors. Caulking, } \\
\text { gasketing, adhesive flashing tape, foam } \\
\text { sealant, or weatherstripping is installed } \\
\text { forming a complete air barrier. }\end{array}$ & & $\begin{array}{l}\text { (Mandatory) Thermal Bypass Inspection } \\
\text { Checklist } \\
1.0 \text { Overall Air Barrier And Thermal } \\
\text { Barrier Alignment. Insulation shall be } \\
\text { installed in full contact with sealed } \\
\text { interior and exterior air barrier except for } \\
\text { alternate to interior air barrier under item }\end{array}$ & $\begin{array}{l}\text { (Mandatory) Thermal Enclosure } \\
\text { System Rater Checklist } \\
\text { 5.0 Air Sealing } \\
5.1 \text { Penetrations to unconditioned } \\
\text { space fully sealed with solid blocking } \\
\text { or flashing as needed and gaps sealed } \\
\text { with caulk or foam. }\end{array}$ & $\begin{array}{l}\text { (Mandatory) Thermal Enclosure } \\
\text { System Rater Checklist } \\
5.0 \text { Air Sealing } \\
5.1 \text { Penetrations to unconditioned } \\
\text { space fully sealed with solid } \\
\text { blocking or flashhing as needed and } \\
\text { gaps sealed with caulk or foam. }\end{array}$ \\
\hline
\end{tabular}




\begin{tabular}{|c|c|c|c|c|c|c|c|c|c|}
\hline Category & Topic & $\begin{array}{l}\text { Requiremem } \\
\text { nt category }\end{array}$ & $\begin{array}{c}\text { IECC } \\
\text { Requirement } \\
\text { Reference } \\
\end{array}$ & IECC 2009 & ICC-700 & LEED for Homes & ES2 & ES2.5 & ES3 \\
\hline & & & & & & & 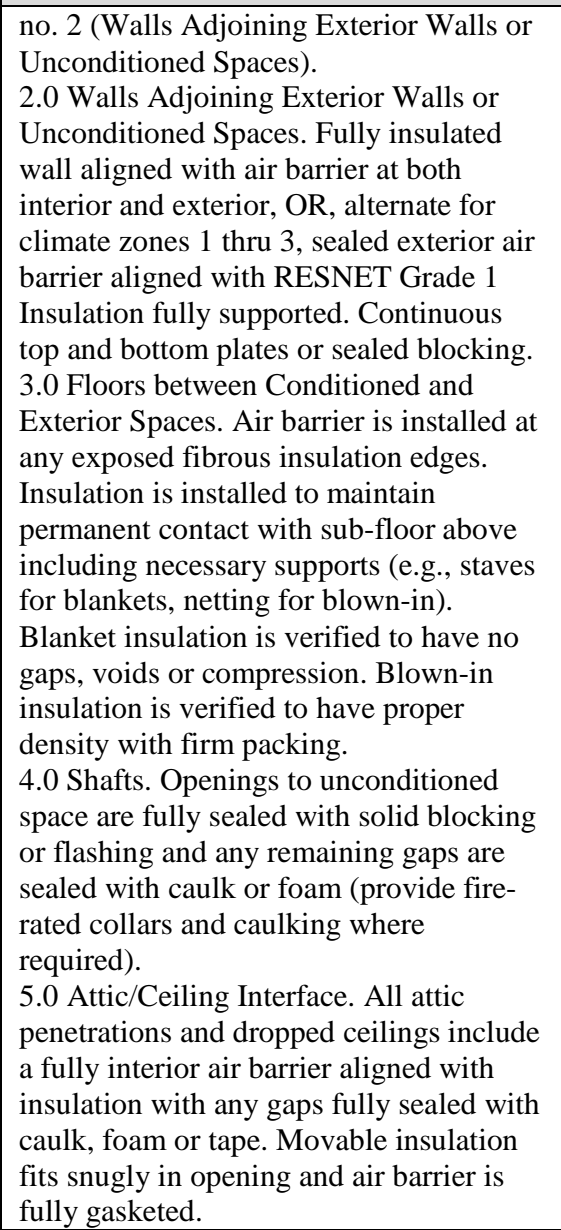 & & \\
\hline $\begin{array}{l}\text { Residential } \\
\text { Energy } \\
\text { Efficiency }\end{array}$ & $\begin{array}{l}\text { Building } \\
\text { Thermal } \\
\text { Envelope }\end{array}$ & Mandatory & $\begin{array}{l}\text { 402.4 Air } \\
\text { leakage. } \\
402.4 .1 \\
\text { Building } \\
\text { thermal } \\
\text { envelope. (5) }\end{array}$ & $\begin{array}{l}\text { The following shall be caulked, } \\
\text { gasketed, weatherstripped or } \\
\text { otherwise sealed with an air } \\
\text { barrier material, suitable film or } \\
\text { solid material: } \\
\text { 5. Dropped ceilings or chases } \\
\text { adjacent to the thermal envelope. }\end{array}$ & $\begin{array}{l}703.2 \text { Insulation and air sealing } \\
\text { (Optional, Prescriptive path). } \\
\text { 703.2.1.4 Ceilings and attics. } \\
\text { (1) At dropped ceilings and soffits, the air } \\
\text { barrier is substantially aligned with } \\
\text { insulation and any gaps are sealed with } \\
\text { caulk, foam, or tape. }\end{array}$ & & $\begin{array}{l}\text { (Mandatoryy) Thermal Bypass Inspection } \\
\text { Checklist } \\
\text { 5.0 Attic/ Ceiling Interface. All attic } \\
\text { penetrations and dropped ceilings include } \\
\text { a full interior air barrier aligned with } \\
\text { insulation with any gaps fully sealed with } \\
\text { caulk, foam or tape. Movable insulation } \\
\text { fits snugly in opening and air barrier is } \\
\text { fullly gasketed. }\end{array}$ & $\begin{array}{l}\text { (Mandatory) Thermal Enclosure } \\
\text { System Rater Checklist } \\
\text { 3.0 Fully-Aligned Air Barriers } \\
\text { 3.3 Ceilings } \\
\text { 3.3.1 Dropped ceiling/soffit below } \\
\text { unconditioned attic. }\end{array}$ & $\begin{array}{l}\text { (Mandatory) Thermal Enclosure } \\
\text { System Rater Checklist } \\
\text { 3.0 Fully-Aligned Air Barriers } \\
\text { 3.3 Ceilings } \\
\text { 3.3.1 Dropped ceiling/soffit below } \\
\text { unconditioned attic. }\end{array}$ \\
\hline $\begin{array}{l}\text { Residential } \\
\text { Energy } \\
\text { Efficiency }\end{array}$ & $\begin{array}{l}\text { Building } \\
\text { Thermal } \\
\text { Envelope }\end{array}$ & $\begin{array}{l}\text { Mandatory } \\
\end{array}$ & $\begin{array}{l}\text { 402.4 Air } \\
\text { leakage. } \\
\text { 402.4.1 } \\
\text { Building } \\
\text { thermal } \\
\text { envelope. (6) }\end{array}$ & $\begin{array}{l}\text { The following shall be caulked, } \\
\text { gasketed, weatherstripped or } \\
\text { otherwise sealed with an air } \\
\text { barrier material, suitable film or } \\
\text { solid material: } \\
\text { 6. Knee walls. }\end{array}$ & $\begin{array}{l}703.2 \text { Insulation and air sealing } \\
\text { (Optional, Prescriptive path). } \\
\text { 703.2.1.3 Walls } \\
\text { (4) Syllight shafts and knee walls are air } \\
\text { sealed. Insulation on attic knee walls and } \\
\text { skylight shatts are physically supported } \\
\text { by stapling in place, netting, or using } \\
\text { other mechanical attachment. } \\
\text { 703.2.1.1. CCilings and atticics. } \\
\text { (2) Access to vented attics, including } \\
\text { knee wall doors and/or drop down stairs, } \\
\text { is caulked gakseted, or otherwise sealed. }\end{array}$ & & $\begin{array}{l}\text { (Mandatory) Thermal Bypass Inspection } \\
\text { Checklist } \\
\text { 2.0 Walls Adjoining Exterior Walls or } \\
\text { Unconditioned Spaces. Fully insulated } \\
\text { wall aligned with air barrier at both } \\
\text { interior and exterior, OR, alternate for } \\
\text { climate zones } 1 \text { thru 3, sealed exterior air } \\
\text { barrier aligned with RESNET Grade } 1 \\
\text { insulation fully supported. Continuous } \\
\text { top and bottom plates or sealed blocking. }\end{array}$ & $\begin{array}{l}\text { (Mandatory) Thermal Enclosure } \\
\text { System Rater Checklist } \\
\text { 3.0 Fully-Aligned Air Barriers } \\
\text { 3.1 Walls } \\
\text { 3.1.3 Attic knee walls / sloped attics }\end{array}$ & $\begin{array}{l}\text { (Mandatory) Thermal Enclosure } \\
\text { System Rater Checklist } \\
\text { 3.0 Fully-Aligned Air Barriers } \\
\text { 3.1 Walls } \\
3.1 .3 \text { Attic knee walls / sloped } \\
\text { attics }\end{array}$ \\
\hline $\begin{array}{l}\text { Residential } \\
\text { Energy } \\
\text { Efficiency }\end{array}$ & $\begin{array}{l}\text { Building } \\
\text { Thermal } \\
\text { Envelope }\end{array}$ & $\begin{array}{l}\text { Mandatory } \\
\end{array}$ & $\begin{array}{l}402.4 \text { Air } \\
\text { leakage. } \\
402.4 .1 \\
\text { Building } \\
\text { thermal } \\
\text { envelope. (7) }\end{array}$ & $\begin{array}{l}\text { The following shall be caulked, } \\
\text { gasketed, weatherstripped or } \\
\text { otherwise sealed with an air } \\
\text { barrier material, suitable film or } \\
\text { solid material: } \\
\text { 7. Walls and ceilings separating } \\
\text { a garage from conditioned } \\
\text { spaces. }\end{array}$ & $\begin{array}{l}\text { 703.2 Insulation and air sealing } \\
\text { (Optional, Prescriptive path). } \\
\text { 703.2.1.2 Air barriers. } \\
\text { Air barrier is installed at any exterior } \\
\text { edge of insulation at floors, foundations, } \\
\text { and crawlspaces including insulated } \\
\text { floors above garages and cantilevered } \\
\text { floors. }\end{array}$ & & $\begin{array}{l}\text { (Mandatory) Thermal Bypass Inspection } \\
\text { Checklist } \\
\text { 2.0 Walls Adjoining Exterior Walls or } \\
\text { Unconditioned Spaces. Fully insulated } \\
\text { wall aligned with air barrier at both } \\
\text { interior and exterior, OR, alternate for } \\
\text { climate zones } 1 \text { thru 3, sealed exterior air } \\
\text { barrier aligned with RESNET Grade } 1\end{array}$ & $\begin{array}{l}\text { (Mandatory) Thermal Enclosure } \\
\text { System Rater Checklist } \\
\text { 3.0 Fully-Aligned Air Barriers: } \\
\text { 3.1 Walls } \\
\text { 3.1.8 Garage rim / band joist } \\
\text { adjoining conditioned space. } \\
\text { 3.2 Floors } \\
\text { 3.2.1 Floor above garage }\end{array}$ & $\begin{array}{l}\text { (Mandatory) Thermal Enclosure } \\
\text { System Rater Checklist } \\
\text { 3.0 Fully-Aligned Air Barriers: } \\
\text { 3.1 Walls } \\
\text { 3.1.8 Garage rim / band joist } \\
\text { adjoining conditioned space. } \\
\text { 3.2 lioors } \\
\text { 3.2.1 Floor above garage }\end{array}$ \\
\hline
\end{tabular}




\begin{tabular}{|c|c|c|c|c|c|c|c|c|c|}
\hline Category & Topic & $\begin{array}{l}\text { Requireme } \\
\text { nt category }\end{array}$ & $\begin{array}{c}\text { IECC } \\
\text { Requirement } \\
\text { Reference }\end{array}$ & IECC 2009 & ICC-700 & LEED for Homes & ES2 & ES2.5 & ES3 \\
\hline & & & & & & & $\begin{array}{l}\text { insulation fully supported. Continuous } \\
\text { top and bottom plates or sealed blocking. }\end{array}$ & $\begin{array}{l}\text { 3.3 Ceilings } \\
\text { 3.3.3 All other ceilings }\end{array}$ & \begin{tabular}{|l|} 
3.3 Ceilings \\
3.3.3 All other ceilings
\end{tabular} \\
\hline $\begin{array}{l}\text { Residential } \\
\text { Energy } \\
\text { Efficiency }\end{array}$ & $\begin{array}{l}\text { Building } \\
\text { Thermal } \\
\text { Envelope }\end{array}$ & Mandatory & $\begin{array}{l}\text { 402.4 Air } \\
\text { leakage. } \\
\text { 402.4.1 } \\
\text { Building } \\
\text { thermal } \\
\text { envelope. (8) }\end{array}$ & $\begin{array}{l}\text { The following shall be caulked, } \\
\text { gasketed, weatherstripped or } \\
\text { otherwise sealed with an air } \\
\text { barrier material, suitable film or } \\
\text { solid material: } \\
\text { 8. Behind tubs and showers on } \\
\text { exterior walls. }\end{array}$ & $\begin{array}{l}\text { 703.2 Insulation and air sealing } \\
\text { (Optional, Prescriptive path). } \\
\text { 703.2.1.3 Walls } \\
\text { (1) Exterior wall(s) behind the } \\
\text { tub/shower is insulated and includes an } \\
\text { interior and exterior air barrier. }\end{array}$ & - & $\begin{array}{l}\text { (Mandatory) Thermal Bypass Inspection } \\
\text { Checklist } \\
\text { 2.0 Walls Adjoining Exterior Walls or } \\
\text { Unconditioned Spaces. Fully insulated } \\
\text { wall aligned with air barrier at both } \\
\text { interior and exterior, OR, alternate for } \\
\text { climate zones } 1 \text { thru 3, sealed exterior air } \\
\text { barrier aligned with RESNET Grade } 1 \\
\text { insulation fully supported. Continuous } \\
\text { top and bottom plates or sealed blocking. }\end{array}$ & $\begin{array}{l}\text { (Mandatory) Thermal Enclosure } \\
\text { System Rater Checklist } \\
\text { 3.0 Fully-Aligned Air Barriers } \\
\text { 3.1 Walls } \\
\text { 3.1.1 Walls behind showers and tubs } \\
\text { 3.1.9 All other exterior walls }\end{array}$ & $\begin{array}{l}\text { (Mandatory) Thermal Enclosure } \\
\text { System Rater Checklist } \\
\text { 3.0 Fully-Aligned Air Barriers } \\
3.1 \text { Walls } \\
3.1 .1 \text { Walls behind showers and } \\
\text { tubs } \\
\text { 3.1.9 All other exterior walls }\end{array}$ \\
\hline $\begin{array}{l}\text { Residential } \\
\text { Energy } \\
\text { Efficiency }\end{array}$ & $\begin{array}{l}\text { Building } \\
\text { Thermal } \\
\text { Envelope }\end{array}$ & Mandatory & $\begin{array}{l}\text { 402.4 Air } \\
\text { leakage. } \\
\text { 402.4.1 } \\
\text { Building } \\
\text { thermal } \\
\text { envelope. (9) }\end{array}$ & $\begin{array}{l}\text { The following shall be caulked, } \\
\text { gasketed, weatherstripped or } \\
\text { otherwise sealed with an air } \\
\text { barrier material, suitable film or } \\
\text { solid material: } \\
\text { 9. Common walls between } \\
\text { dwelling units. }\end{array}$ & $\begin{array}{l}\text { 703.2 Insulation and air sealing } \\
\text { (Optional, Prescriptive path). } \\
\text { 703.2.1.3 Walls } \\
\text { (3) Duplex and townhouse construction: } \\
\text { In the common walls between dwelling } \\
\text { units (e.g.,. gypsum shaft wall), an air } \\
\text { barrier is installed to seal the gap between } \\
\text { the common wall and the structural } \\
\text { framing. }\end{array}$ & - & $\begin{array}{l}\text { (Mandatory) Thermal Bypass Inspection } \\
\text { Checklist } \\
\text { 6.0 Common Walls Between Dwelling } \\
\text { Units. Gap between drywall shaft wall } \\
\text { (i.e., common wall) and the structural } \\
\text { framing between units is fully sealed at } \\
\text { all exterior boundary conditions. }\end{array}$ & $\begin{array}{l}\text { (Mandatory) Thermal Enclosure } \\
\text { System Rater Checklist } \\
\text { 3.0 Fully-Aligned Air Barriers: } \\
\text { 3.1 Walls } \\
\text { 3.1.7 Double walls } \\
\text { 5.0 Air Sealing } \\
5.2 \text { Cracks in the building envelope } \\
\text { fully sealed } \\
\text { 5.2.7 In multi-family buildings, the } \\
\text { gap between the drywall shaft wall } \\
\text { (i.e. common wall) and the structural } \\
\text { framing between units fully sealed at } \\
\text { all exterior boundary conditions. }\end{array}$ & $\begin{array}{l}\text { (Mandatory) Thermal Enclosure } \\
\text { System Rater Checklist } \\
\text { 3.0 Fully-Aligned Air Barriers: } \\
\text { 3.1 Walls } \\
\text { 3.1.7 Double walls } \\
5.0 \text { Air Sealing } \\
\text { 5.2 Cracks in the building envelope } \\
\text { fully sealed } \\
\text { 5.2.7 In multi-family buildings, the } \\
\text { gap between the drywall shaft wall } \\
\text { (i.e. common wall) and the } \\
\text { structural framing between units } \\
\text { fully sealed at all exterior boundary } \\
\text { conditions. }\end{array}$ \\
\hline $\begin{array}{l}\text { Residential } \\
\text { Energy } \\
\text { Efficiency }\end{array}$ & $\begin{array}{l}\text { Building } \\
\text { Thermal } \\
\text { Envelope }\end{array}$ & Mandatory & $\begin{array}{l}\text { 402.4 Air } \\
\text { leakage. } \\
\text { 402.4.1 } \\
\text { Building } \\
\text { thermal } \\
\text { envelope. (10) }\end{array}$ & $\begin{array}{l}\text { The following shall be caulked, } \\
\text { gasketed, weatherstripped or } \\
\text { otherwise sealed with an air } \\
\text { barrier material, suitable film or } \\
\text { solid material: } \\
\text { 10. Attic access openings. }\end{array}$ & $\begin{array}{l}\text { 703.2 Insulation and air sealing } \\
\text { (Optional, Prescriptive path). } \\
\text { 703.2.1.4 Ceilings and attics. } \\
\text { (2) Access to vented attics, including } \\
\text { knee wall doors and/or drop down stairs, } \\
\text { is caulked, gasketed, or otherwise sealed. }\end{array}$ & & $\begin{array}{l}\text { (Mandatory) Thermal Bypass Inspection } \\
\text { Checklist } \\
\text { 2.0 Walls Adjoining Exterior Walls or } \\
\text { Unconditioned Spaces. Fully insulated } \\
\text { wall aligned with air barrier at both } \\
\text { interior and exterior, OR, alternate for } \\
\text { climate onones } 1 \text { thru 3, sealed exterior air } \\
\text { barrier aligned with RESNET Grade } 1 \\
\text { insulation fully supported. Continuous } \\
\text { top and bottom plates or sealed blocking. } \\
\text { 5.0 Attic/ Ceiling Interface. All attic } \\
\text { penetrations and dropped ceilings include } \\
\text { a full interior air barrier aligned with } \\
\text { insulation with any gaps fully sealed with } \\
\text { caulk, foam or tape. Movable insulation } \\
\text { fits snugly in opening and air burrier is } \\
\text { fully gasketed. }\end{array}$ & \begin{tabular}{l|} 
(Mandatory) Thermal Enclosure \\
System Rater Checklist \\
5.0 Air Sealing \\
5.3 Other Ceilings \\
5.3 .2 Attic access panels and drop- \\
down stairs equipped with a durable \\
$\geq \mathrm{R}-10$ insulated cover that is gasketed \\
(i.e., not caulked) to produce \\
continuous air seal when occupant is \\
not accessing the attic.
\end{tabular} & $\begin{array}{l}\text { (Mandatory) Thermal Enclosure } \\
\text { System Rater Checklist } \\
\text { 5.0 Air Sealing } \\
\text { 5.3 Other Ceilings } \\
\text { 5.3.2 Attic access panels and drop- } \\
\text { down stairs equipped with a } \\
\text { durable } \geq R-10 \text { insulated cover that } \\
\text { is gasketed (i.e., not caulked) to } \\
\text { produce continuous air seal when } \\
\text { occupant is not accessing the attic. }\end{array}$ \\
\hline $\begin{array}{l}\text { Residential } \\
\text { Energy } \\
\text { Efficiency }\end{array}$ & $\begin{array}{l}\text { Building } \\
\text { Thermal } \\
\text { Envelope }\end{array}$ & Mandatory & $\begin{array}{l}\text { 402.4 Air } \\
\text { leakage. } \\
\text { 402.4.1 } \\
\text { Building } \\
\text { thermal } \\
\text { envelope. (11) }\end{array}$ & $\begin{array}{l}\text { The following shall be caulked, } \\
\text { gasketed, weatherstripped or } \\
\text { otherwise sealed with an air } \\
\text { barrier material, suitable film or } \\
\text { solid material: } \\
\text { 11. Rim joist junction. }\end{array}$ & $\begin{array}{l}\text { 701.4.3. Insulation and air sealing } \\
\text { (Mandatory) } \\
\text { 701.4.3.3 Walls } \\
\text { (2) Band joist and rim joints. Band and } \\
\text { rim joists are insulated and air sealed. }\end{array}$ & & $\begin{array}{l}\text { (Mandatory) Thermal Bypass Inspection } \\
\text { Checklist } \\
\text { 3.0 Floors between Conditioned and } \\
\text { Exterior Spaces. Air barrier is installed at } \\
\text { any exposed fibrous insulation edges. } \\
\text { Insulation is installed to maintain } \\
\text { permanent contact with sub-floor above } \\
\text { including necessary supports (e.g., staves } \\
\text { for blankets, netting for blown-in). } \\
\text { Blanket insulation is verified to have no } \\
\text { gaps, voids or compression. Blown-in } \\
\text { insulation is verified to have proper } \\
\text { density with firm packing. }\end{array}$ & 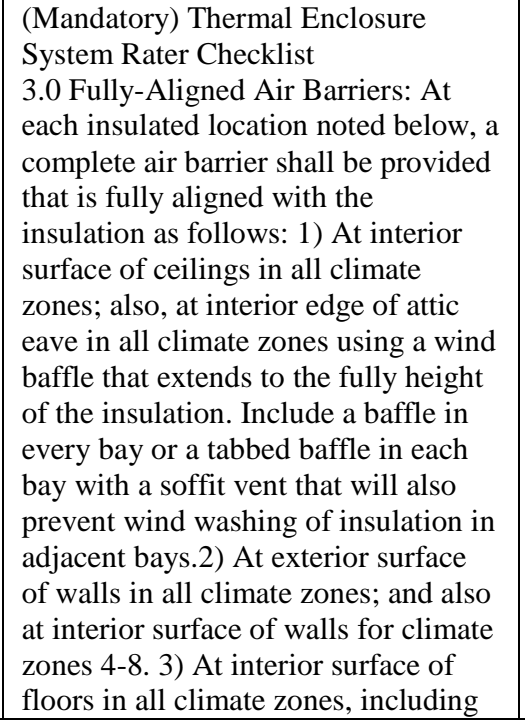 & $\begin{array}{l}\text { (Mandatory) Thermal Enclosure } \\
\text { System Rater Checklist } \\
\text { 3.0 Fullly-Aligned Air Barriers: At } \\
\text { each insulated location noted } \\
\text { belows a complete ir barrier shall } \\
\text { be provided that is fully aligned } \\
\text { with the insulation as follows: } 1 \text { ) } \\
\text { At interior surface of ceilings in all } \\
\text { climate zones; also, at interior edge } \\
\text { of attic eave in all climate zones } \\
\text { using a wind baffle that extends to } \\
\text { the fully height of the insulation. } \\
\text { Include a baffle in every bay or a } \\
\text { tabbed baffle in each bay with a } \\
\text { soffit vent that will also prevent } \\
\text { wind washing of insulation in } \\
\text { adjacent bays.2) At exterior surface } \\
\text { of walls in all climate zones; and } \\
\text { also at interior surface of walls for } \\
\text { climate zones 4-8. 3) At interior }\end{array}$ \\
\hline
\end{tabular}




\begin{tabular}{|c|c|c|c|c|c|c|c|c|c|}
\hline Category & Topic & $\begin{array}{l}\text { Requireme } \\
\text { nt category }\end{array}$ & $\begin{array}{c}\text { IECC } \\
\text { Requirement } \\
\text { Reference } \\
\end{array}$ & IECC 2009 & ICC-700 & LEED for Homes & ES2 & ES2.5 & ES3 \\
\hline & & & & & & & & $\begin{array}{l}\text { supports to ensure permanent contact } \\
\text { and blocking at exposed edges. } \\
3.1 \text { Walls } \\
3.1 .8 \text { Garage rim / band joist } \\
\text { adjoining conditioned space }\end{array}$ & $\begin{array}{l}\text { surface of floors in all climate } \\
\text { zones, including supports to ensure } \\
\text { permanent contact and blocking at } \\
\text { exposed edges. } \\
3.1 \text { Walls } \\
3.1 .8 \text { Garage rim / band joist } \\
\text { adjoining conditioned space }\end{array}$ \\
\hline $\begin{array}{l}\text { Residential } \\
\text { Energy } \\
\text { Efficiency }\end{array}$ & $\begin{array}{l}\text { Building } \\
\text { Thermal } \\
\text { Envelope }\end{array}$ & Mandatory & $\begin{array}{l}402.4 \text { Air } \\
\text { leakage. } \\
402.4 .1 \\
\text { Building } \\
\text { thermal } \\
\text { envelope. (12) }\end{array}$ & $\begin{array}{l}\text { The following shall be caulked, } \\
\text { gasketed, weatherstripped or } \\
\text { otherwise sealed with an air } \\
\text { barrier material, suitable film or } \\
\text { solid material: } \\
\text { 12. Other sources of infiltration. }\end{array}$ & $\begin{array}{l}\text { 701.4.3.3 Walls (Mandatory) } \\
\text { (3) Between foundation and sill plate } \\
\text { bottom plate... } \\
\text { (5) Exterior architectural features. Code } \\
\text { required building envelope insulation and } \\
\text { air sealing are not disrupted at exterior } \\
\text { architectural features such as stairs and } \\
\text { decks. } \\
\text { 703.2.1.1.4 HVAC register boots } \\
\text { (Optional). HVAC register boots that } \\
\text { penetrate the building enveloepe are } \\
\text { caulked or sealed to the subfloor or } \\
\text { drywall. } \\
\text { 703.2.1.4 Ceilings and attics (Optional). } \\
\text { (3) An insulated cover is gasketed or } \\
\text { sealed to the attic opening where a whole } \\
\text { building or whole dwelling unit fan } \\
\text { penetrates into the attic. }\end{array}$ & & 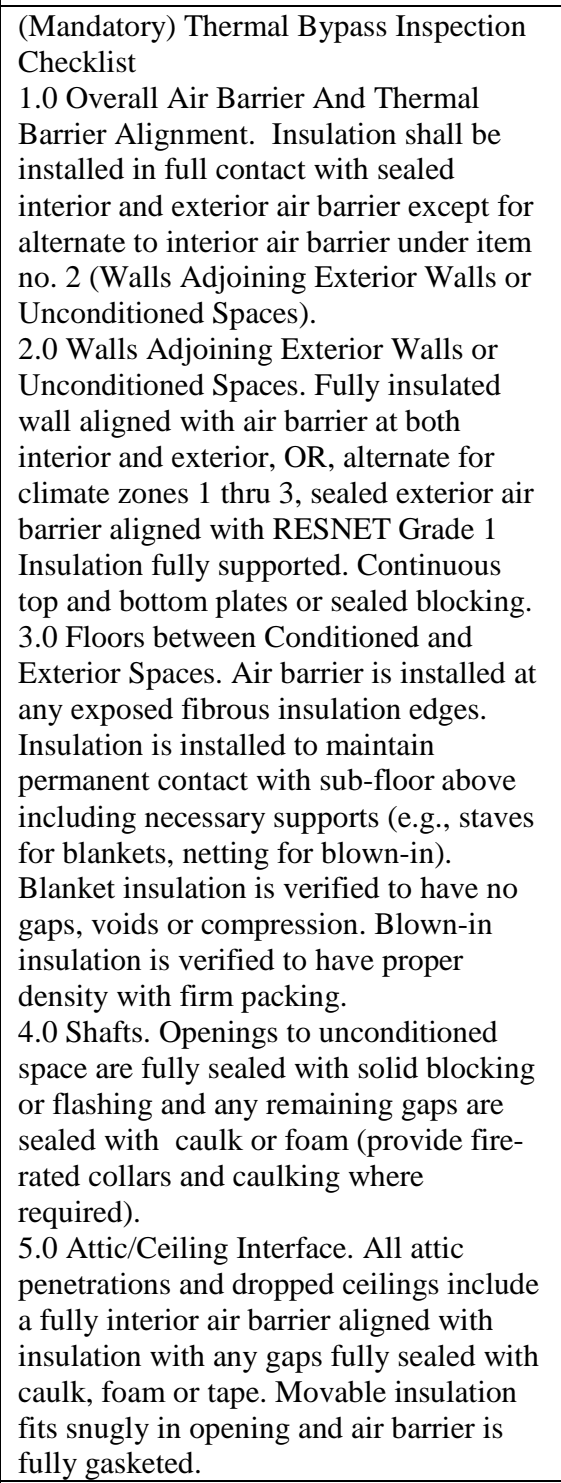 & $\begin{array}{l}\text { (Mandatory) Thermal Enclosure } \\
\text { System Rater Checklist } \\
5.0 \text { Air Sealing } \\
5.1 \text { Penetrations to unconditioned } \\
\text { space fully sealed with solid blocking } \\
\text { or flashing as needed and gaps sealed } \\
\text { with caulk or foam. } \\
5.2 \text { Cracks in the building envelope } \\
\text { fully sealed } \\
5.3 \text { Other openings }\end{array}$ & $\begin{array}{l}\text { (Mandatory) Thermal Enclosure } \\
\text { System Rater Checklist } \\
5.0 \text { Air Sealing } \\
5.1 \text { Penetrations to unconditioned } \\
\text { space fully sealed with solid } \\
\text { blocking or flashing as needed and } \\
\text { gaps sealed with caulk or foam. } \\
5.2 \text { Cracks in the building envelope } \\
\text { fully sealed } \\
5.3 \text { Other openings }\end{array}$ \\
\hline $\begin{array}{l}\text { Residential } \\
\text { Energy } \\
\text { Efficiency }\end{array}$ & $\begin{array}{l}\text { Building } \\
\text { Thermal } \\
\text { Envelope }\end{array}$ & Mandatory & $\begin{array}{l}402.4 \text { Air } \\
\text { leakage. } \\
\text { 402.4.2 Air } \\
\text { sealing and } \\
\text { insulation. } \\
\text { 402.4.2.1. } \\
\text { Testing option. }\end{array}$ & $\begin{array}{l}\text { Building envelope air tightness } \\
\text { and insulation installation shall } \\
\text { be demonstrated to comply with } \\
\text { one of the following options } \\
\text { given by Section 402.4.2.1 or } \\
\text { 402.4.2.2.2: } \\
\text { 402.4.2. Testing option. } \\
\text { Building envelope tightness and } \\
\text { insulation installation shall be } \\
\text { considered acceptable when } \\
\text { tested air leakage is less than } \\
\text { seven air changes per hour } \\
\text { (ACH) when tested with } \\
\text { blower door at a pressure of } 50 \\
\text { pascals (1 psff). Testing shall }\end{array}$ & 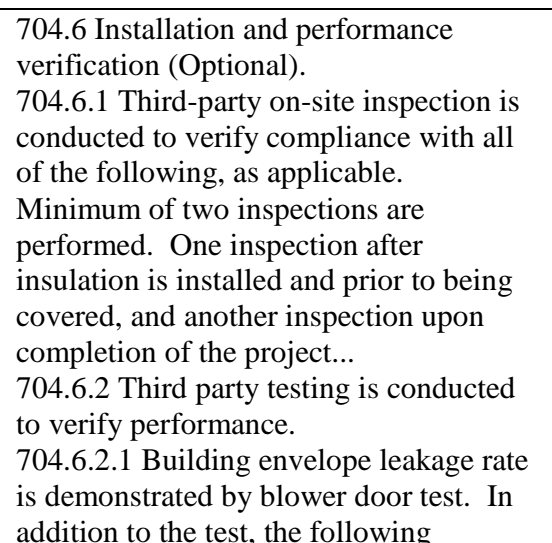 & $\begin{array}{l}\text { EA 3: Air Infiltration - Prescriptive Path } \\
\text { Pre-requisite 3.1 (Mandatory). Reduced } \\
\text { Envelope Leakage. Meet the air leakege } \\
\text { requirements shown in Table 1. The air } \\
\text { leakage rate must be tested and verified by an } \\
\text { energy rater. } \\
\text { Credit } 3.2 \text { (Optional). Greatly Reduced } \\
\text { Envelope Leakage. Meet the air leakage } \\
\text { requirements shown in Table 1. The air } \\
\text { leakage rate must be tested and verified by an } \\
\text { energy rater. } \\
\text { OR } \\
\text { Credit } 3.3 \text { (Optional) Minimal Envelope } \\
\text { Leakage. Meet the air leakage requirements } \\
\text { shown in Table 1. The air leakage rate must }\end{array}$ & $\begin{array}{l}\text { (Mandatory) Thermal Bypass Inspection } \\
\text { Checklist } \\
1.0 \text { Overall Air Barrier And Thermal } \\
\text { Barrier Alignment. Insulation shall be } \\
\text { installed in full contact with sealed } \\
\text { interior and exterior air barrier except for } \\
\text { alternate to interior air barrier under item } \\
\text { no. } 2 \text { (Walls Adjoiningn Exterior Walls or } \\
\text { Unconditioned Spaces). } \\
2.0 \text { Walls Adjoining Exterior Walls or } \\
\text { Unconditioned Spaces. Fully insulated } \\
\text { wall aligned with air barrier at both } \\
\text { interior and exterior, OR, alternate for } \\
\text { climate zones } 1 \text { thru } 3 \text {, sealed exterior air } \\
\text { barrieir alingened with RESNET Grade } 1\end{array}$ & $\begin{array}{l}\text { (Mandatory) HVAC System Quality } \\
\text { Installation Contractor Checklist } \\
\text { 2.10 HVAC Infiltration rates shall be } \\
\text { less than or equal to the following } \\
\text { values: } \\
6 \text { ACH50 in CZs 1,2 } \\
5 \text { ACH50 in CZs 3,4 } \\
4 \text { ACH50 in CZs 5,6,7 } \\
3 \text { ACH50 in CZ } 8\end{array}$ & $\begin{array}{l}\text { (Mandatory) HVAC System } \\
\text { Quality Installation Contractor } \\
\text { Checklist } \\
\text { 2.10 HVAC Infiltration rates shall } \\
\text { be less than or equal to the } \\
\text { following values: } \\
6 \text { ACH50 in CZs } 1,2 \\
5 \text { ACH50 in CZs 3,4 } \\
4 \text { ACH50 in CZs 5,6,7 } \\
3 \text { ACH50 in CZ } 8\end{array}$ \\
\hline
\end{tabular}




\begin{tabular}{|c|c|c|c|c|c|c|c|c|c|}
\hline Category & Topic & $\begin{array}{l}\text { Requireme } \\
\text { nt category }\end{array}$ & $\begin{array}{c}\text { IECC } \\
\text { Requirement } \\
\text { Reference }\end{array}$ & IECC 2009 & ICC-700 & LEED for Homes & ES2 & ES2.5 & ES3 \\
\hline & & & & $\begin{array}{l}\text { occur after rough in and after } \\
\text { installation of penetrations of the } \\
\text { building envelope, including } \\
\text { penetrations for utilities, } \\
\text { plumbing, electrical, ventilation } \\
\text { and combustion appliances. } \\
\text { During testing: } \\
\text { 1. Exterior windows and doors, } \\
\text { fireplace and stove doors shall be } \\
\text { closed, but not sealed; } \\
\text { 2. Dampers shall be closed, but } \\
\text { not sealed, including exhaust, } \\
\text { intake, makeup air, backdraft and } \\
\text { flue dampers; } \\
\text { 3. Interior doors shall be open; } \\
\text { 4. Exterior openings for } \\
\text { continuous ventilation systems } \\
\text { and heat recovery ventilators } \\
\text { shall be closed and sealed; } \\
\text { 5. Heating and cooling system(s) } \\
\text { shall be turned off; } \\
\text { 6. HVAC ducts shall not be } \\
\text { sealed; and } \\
\text { 7. Supply and return registers } \\
\text { shall not be sealed. }\end{array}$ & $\begin{array}{l}\text { practices are required... } \\
\text { (4) The maximum leakage rate is in } \\
\text { accordance with: } \\
\text { (a) } 5 \text { ACH50 ( } 3 \text { points) } \\
\text { (b) } 4 \text { ACH50 (6 points) } \\
\text { (c) } 3 \text { ACH50 }(9 \text { points) } \\
\text { (d) } 2 \text { ACH50 }(12 \text { points }) \\
\text { (e) } 1 \text { ACH50 ( } 15 \text { points) }\end{array}$ & be tested and verified by an energy rater. & $\begin{array}{l}\text { Insulation fully supported. Continuous } \\
\text { top and bottom plates or sealed blocking. } \\
3.0 \text { Floors between Conditioned and } \\
\text { Exterior Spaces. Air barrier is installed at } \\
\text { any exposed fibrous insulation edges. } \\
\text { Insulation is installed to maintain } \\
\text { permanent contact with sub-floor above } \\
\text { including necessary supports (e.g., staves } \\
\text { for blankets, netting for blowh-in). } \\
\text { Blanket insulation is verified to have no } \\
\text { gaps, voids or compression. Blown-in } \\
\text { insulation is verified to have proper } \\
\text { density with firm packing. } \\
4.0 \text { Shafts. Openings to unconditioned } \\
\text { space are fully sealed with solit blocking } \\
\text { or flashing and any remaining gaps are } \\
\text { sealed with caulk or foam (provide fire- } \\
\text { rated collars and caulking where } \\
\text { required). } \\
5.0 \text { Attic/Ceiling Interface. All attic } \\
\text { penetrations and dropped ceilings include } \\
\text { a fully interior air barrier aligned with } \\
\text { insulation with any gaps fully sealed with } \\
\text { caulk, foam or tape. Movable insulation } \\
\text { fits snugly in opening and air barrier is } \\
\text { fully gasketed. }\end{array}$ & & \\
\hline $\begin{array}{l}\text { Residential } \\
\text { Energy } \\
\text { Efficiency }\end{array}$ & $\begin{array}{l}\text { Building } \\
\text { Thermal } \\
\text { Envelope }\end{array}$ & Mandatory & $\begin{array}{l}402.4 \text { Air } \\
\text { leakage. } \\
\text { 402.4.2 Air } \\
\text { sealing and } \\
\text { insulation. } \\
\text { 402.4.2.2. } \\
\text { Visual } \\
\text { inspection } \\
\text { option. }\end{array}$ & $\begin{array}{l}\text { Building envelope air tightness } \\
\text { and insulation installation shall } \\
\text { be demonstrated to comply with } \\
\text { one of the following options } \\
\text { given by Section 402.4.2.1 or } \\
\text { 402.4.2.2.2: } \\
\text { 402.4.2.2 Visual inspection } \\
\text { option. Building envelope } \\
\text { tightness and insulation } \\
\text { installation shall be considered } \\
\text { acceptable when the items listed } \\
\text { in Table 402.4.2, applicable to } \\
\text { the method of construction, are } \\
\text { field verified. Where required by } \\
\text { the code official, an approved } \\
\text { party independent from the } \\
\text { installer of the insulation shall } \\
\text { inspect the air barrier and } \\
\text { insulation. }\end{array}$ & $\begin{array}{l}703.2 \text { Insulation and air sealing } \\
\text { (Optional, Prescriptive path). } \\
\text { 703.2.2. Insulation and air sealing is } \\
\text { installed in accordance with all of the } \\
\text { following [Sections } 703.2 .1 .1-703.2 .1 .4] \text {, } \\
\text { as applicable: } \\
\text { (1) third-party verification performed } \\
\text { 704.6 Installation and performance } \\
\text { verification (OPtional). } \\
\text { 704.6.1 Third-party on-site inspection is } \\
\text { conducted to verify compliance with all } \\
\text { of the following, as applicable. } \\
\text { Minimum of two inspections are } \\
\text { performed. One inspection after } \\
\text { insulation is installed and prior to being } \\
\text { covered, and another inspection upon } \\
\text { completion of the project... }\end{array}$ & & 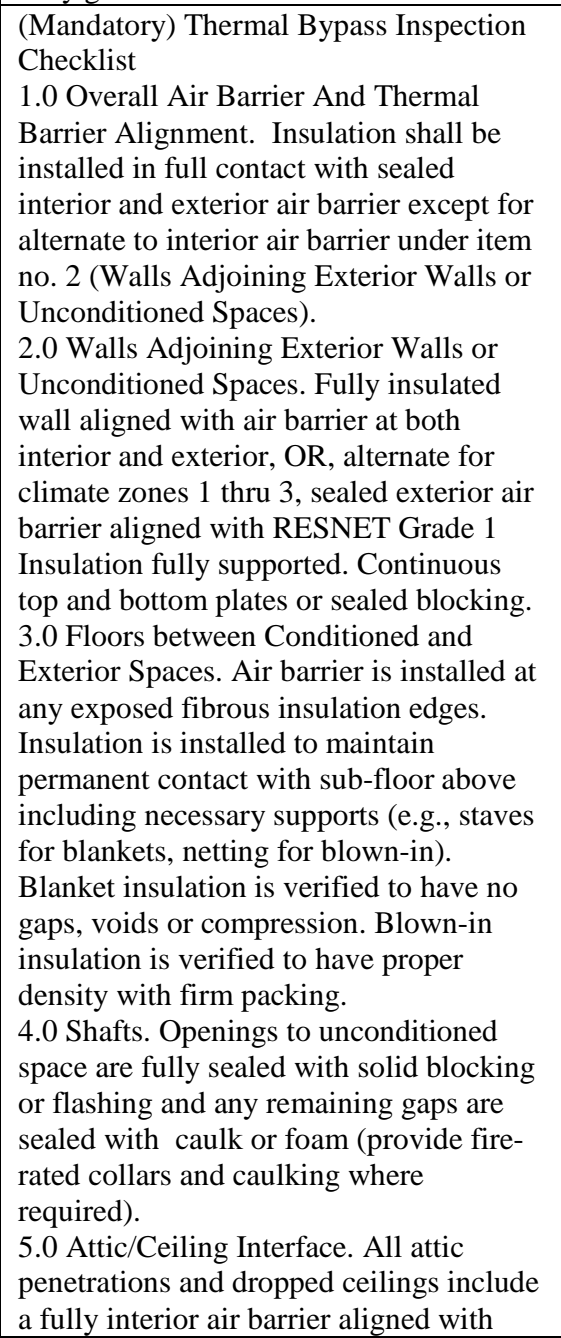 & $\begin{array}{l}\text { (Mandatory) HVAC System Quality } \\
\text { Installation Contractor Checklist } \\
\text { 3. Fully-Aligned Air Barriers } \\
\text { 5. Air Sealing } \\
\text { 5.3 Other Openings }\end{array}$ & $\begin{array}{l}\text { (Mandatory) HVAC System } \\
\text { Quality Installation Contractor } \\
\text { Checklist } \\
\text { 3. Fully-Aligned Air Barriers } \\
\text { 5. Air Sealing } \\
\text { 5.3 Other Openings }\end{array}$ \\
\hline
\end{tabular}




\begin{tabular}{|c|c|c|c|c|c|c|c|c|c|}
\hline Category & Topic & $\begin{array}{l}\text { Requireme } \\
\text { nt category }\end{array}$ & $\begin{array}{c}\text { IECC } \\
\text { Requirement } \\
\text { Reference }\end{array}$ & IECC 2009 & ICC-700 & LEED for Homes & ES2 & ES2.5 & ES3 \\
\hline & & & & & & & $\begin{array}{l}\text { insulation with any gaps fully sealed with } \\
\text { caulk, foam or tape. Movable insulation } \\
\text { fits snugly in opening and air barrier is } \\
\text { fully gasketed. }\end{array}$ & & \\
\hline $\begin{array}{l}\text { Residential } \\
\text { Energy } \\
\text { Efficiency }\end{array}$ & $\begin{array}{l}\text { Building } \\
\text { Thermal } \\
\text { Envelope }\end{array}$ & Mandatory & $\begin{array}{l}\text { 402.4 Air } \\
\text { leakage. } \\
\text { 402.4.3 } \\
\text { Fireplaces. }\end{array}$ & $\begin{array}{l}\text { New wood-burning fireplaces } \\
\text { shall have gasketedd doors and } \\
\text { outdoor combustion air. }\end{array}$ & $\begin{array}{l}\text { 703.2.1.1.5 Masonry Fireplaces } \\
\text { (Optional, Prescriptive path). Masonry } \\
\text { fireplaces are equipped with gasketed } \\
\text { doors, outside combustion air, and a } \\
\text { chimney top damper. }\end{array}$ & $\begin{array}{l}\text { EQ 2: Combustion Venting - Prescriptive } \\
\text { Path } \\
\text { Prerequisite } 2.1 \text { Basic Combustion Venting } \\
\text { Measures (Mandatory). Meet all the } \\
\text { following requirements... } \\
\text { c) All fireplaces and woodstoves must have } \\
\text { doors. } \\
\text { d) Space and water heating equipment that } \\
\text { involves combustion must meet one of the } \\
\text { following... } \\
\text { i. it must be designed and installed with } \\
\text { closed combustion (i.e., sealed supply air and } \\
\text { exhaust ducting } \\
\text { ii. it must be designed and installed with } \\
\text { power-vented exhaust; or } \\
\text { iii. it must be located in a detached utility } \\
\text { building or open-air facility. } \\
\text { Credit } 2.2 \text { Enhanced Combustion Venting } \\
\text { Measures (Optional). Install no fireplace or } \\
\text { woodstove, or design and install a fireplace } \\
\text { or woodstove according to the requirements } \\
\text { in Table } 1 .\end{array}$ & - & - & - \\
\hline $\begin{array}{l}\text { Residential } \\
\text { Energy } \\
\text { Efficiency }\end{array}$ & $\begin{array}{l}\text { Building } \\
\text { Thermal } \\
\text { Envelope }\end{array}$ & Mandatory & $\begin{array}{l}\text { 402.4 Air } \\
\text { leakage. } \\
\text { 402.4.4 } \\
\text { Fenestration air } \\
\text { leakage. }\end{array}$ & 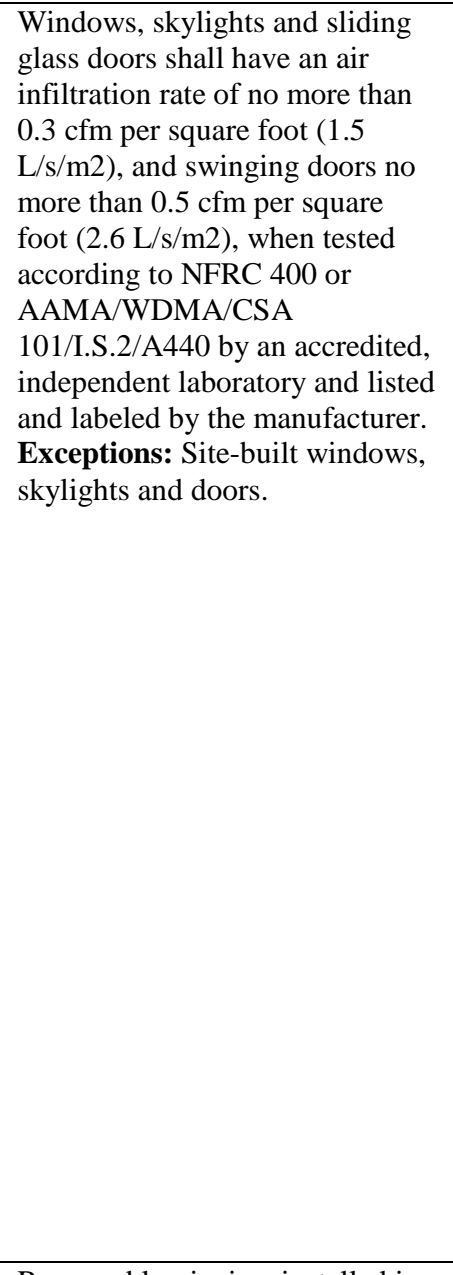 & 70M & & 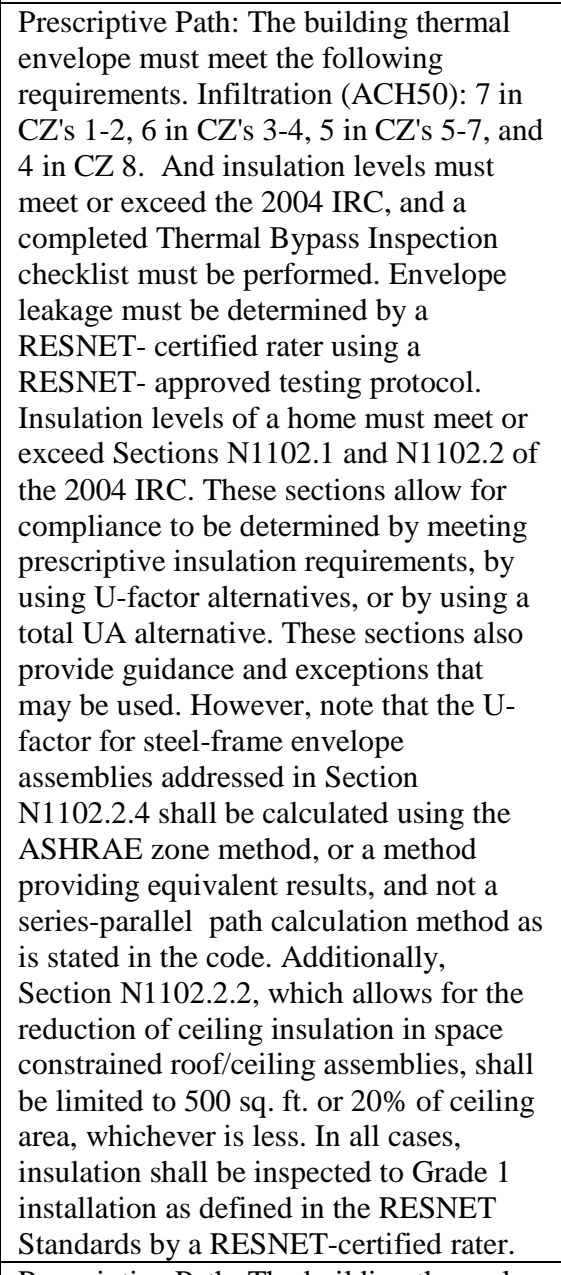 & $\begin{array}{l}\text { (Recommended) Thermal Enclosure } \\
\text { System Rater Checklist } \\
\text { 1.0 High-Performance Fenestration } \\
\text { 1.1 Prescriptive Pathl Fenestration } \\
\text { shall meet or exceed ENERGY } \\
\text { STAR* requirements. } \\
\text { 1.2 Performance Path: Fenestration } \\
\text { shall meet or exceed } 2009 \text { IECC } \\
\text { requirements. } \\
\text { *ENERGY STAR Program } \\
\text { Requirements for Residential } \\
\text { Windows, Doors, and Skylights - } \\
\text { Version 5.0 as outlined at } \\
\text { www.energystar.gov/windows. }\end{array}$ & $\begin{array}{l}\text { (Mandatory) Thermal Enclosure } \\
\text { System Rater Checklist } \\
\text { 1.0 High-Performance Fenestration } \\
\text { 1.1 Prescriptive Path: Fenestration } \\
\text { shall meet or exceed ENERGY } \\
\text { STAR* requirements. } \\
\text { 1.2 Performance Path: Fenestration } \\
\text { shall meet or exceed } 2009 \text { IECC } \\
\text { requirements. } \\
\text { *ENERGY STAR Program } \\
\text { Requirements for Residential } \\
\text { Windows, Doors, and Skylights - } \\
\text { Version 5.0 as outlined at } \\
\text { www.energystar.gov/windows. }\end{array}$ \\
\hline Residential & Building & Mandatory & 402.4 Air & Recessed luminaires installed in & 701.4.3.4 Ceilings and attics (Mandatory) & & Prescriptive Path: The building thermal & (Mandatory) Thermal Enclosure & atory) Thermal Enclos \\
\hline
\end{tabular}




\begin{tabular}{|c|c|c|c|c|c|c|c|c|c|}
\hline Category & Topic & $\begin{array}{l}\text { Requireme } \\
\text { nt category }\end{array}$ & $\begin{array}{c}\text { IECC } \\
\text { Requirement } \\
\text { Reference }\end{array}$ & IECC 2009 & ICC-700 & LEED for Homes & ES2 & ES2.5 & ES3 \\
\hline $\begin{array}{l}\text { Energy } \\
\text { Efficiency }\end{array}$ & $\begin{array}{l}\text { Thermal } \\
\text { Envelope }\end{array}$ & & $\begin{array}{l}\text { leakage. } \\
402.4 .5 \\
\text { Recessed } \\
\text { lighting. }\end{array}$ & $\begin{array}{l}\text { the building thermal envelope } \\
\text { shall be sealed to limit air } \\
\text { leakage between conditioned and } \\
\text { unconditioned spaces. All } \\
\text { recessed luminaires shall be IC- } \\
\text { rated and labeled as meeting } \\
\text { ASTM E E283 when tested at } 1.57 \\
\text { psf ( } 75 \text { Pa) pressure differential } \\
\text { with no more than } 2.0 \text { cfm } \\
\text { (0.944 L//s) of air movement } \\
\text { from the conditioned space to the } \\
\text { ceiling cavity. All recessed } \\
\text { luminaires shall be sealed with a } \\
\text { gasket or caullk between the } \\
\text { housing and the interior wall or } \\
\text { ceiling covering. }\end{array}$ & $\begin{array}{l}\text { (2) Recessed lighting. Recessed light } \\
\text { fixtures that penetrate the thermal } \\
\text { envelope are airtight, IC-rated, and sealed } \\
\text { with gasket, caulk, or foam. }\end{array}$ & & 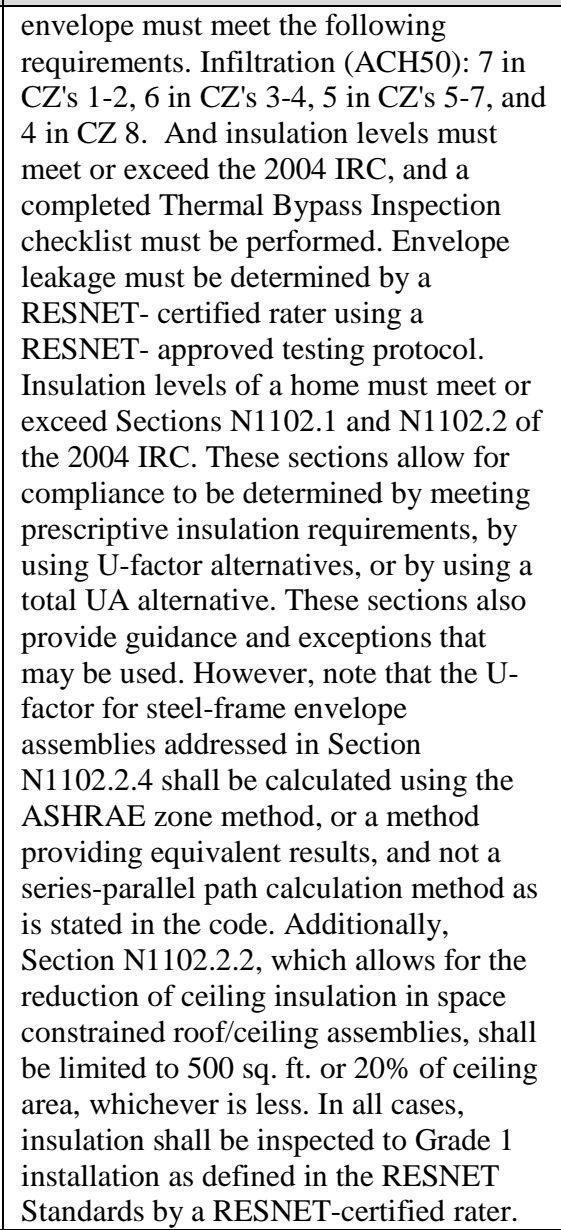 & $\begin{array}{l}\text { System Rater Checklist } \\
5.0 \text { Air Sealing } \\
5.1 .5 \text { Recessed lighting fixtures } \\
\text { adjacent to unconditioned space } \\
\text { ICAT labeled and fully gasketed. } \\
\text { Also, if in insulated ceiling without } \\
\text { attic above, exterior surface of fixture } \\
\text { insulated to } \geq R-10 \text { in climate zone } 4 \\
\text { and higher to minimize condensation } \\
\text { potential. }\end{array}$ & $\begin{array}{l}\text { System Rater Checklist } \\
5.0 \text { Air sealing } \\
\text { 5.1.5 Recessed lighting fixtures } \\
\text { adjacent to unconditioned space } \\
\text { ICAT labeled and fully gasketed. } \\
\text { Also, if in insulated ceiling without } \\
\text { attic above, exterior surface of } \\
\text { fixture insulated to } \geq R-10 \text { in } \\
\text { climate zone } 4 \text { and higher to } \\
\text { minimize condensation potential. }\end{array}$ \\
\hline $\begin{array}{c}\text { Residential } \\
\text { Energy } \\
\text { Efficiency }\end{array}$ & $\begin{array}{l}\text { Building } \\
\text { Thermal } \\
\text { Envelope }\end{array}$ & Mandatory & $\begin{array}{l}402.5 \\
\text { Maximum } \\
\text { fenestration U- } \\
\text { factor and } \\
\text { SHGC. }\end{array}$ & $\begin{array}{l}\text { The area-weighted average } \\
\text { maximum fenestration U-factor } \\
\text { permitted using trade-offs from } \\
\text { Section } 402.1 .4 \text { or } 404 \text { shall be } \\
0.48 \text { in Zones } 4 \text { and } 5 \text { and } 0.40 \text { in } \\
\text { Zones } 6 \text { through } 8 \text { for vertical } \\
\text { fenestration, and } 0.75 \text { in Zones } 4 \\
\text { through } 8 \text { for skylights. The } \\
\text { area-weighted average maximum } \\
\text { fenestration } 5 \text { SHCC permitted } \\
\text { using trade-offs from Section } \\
404 \text { in Zones } 1 \text { through } 3 \text { shall } \\
\text { be } 0.50 \text {. }\end{array}$ & & & & $\begin{array}{l}\text { (Recommended) Thermal Enclosure } \\
\text { System Rater Checklist } \\
1.0 \text { High-Performance Fenestration } \\
1.1 \text { Prescriptive Path: Fenestration } \\
\text { shall meet or exceed ENERGY } \\
\text { STAR* requirements. } \\
1.2 \text { Performance Path: Fenestration } \\
\text { shall meet or exceed 2009 IECC } \\
\text { requirements. } \\
\text { *ENERGY STAR Program } \\
\text { Requirements for Residential } \\
\text { Windows, Doors, and Skylights - } \\
\text { Version 5.0 as outlined at } \\
\text { www.energystar. gove/windows. }\end{array}$ & 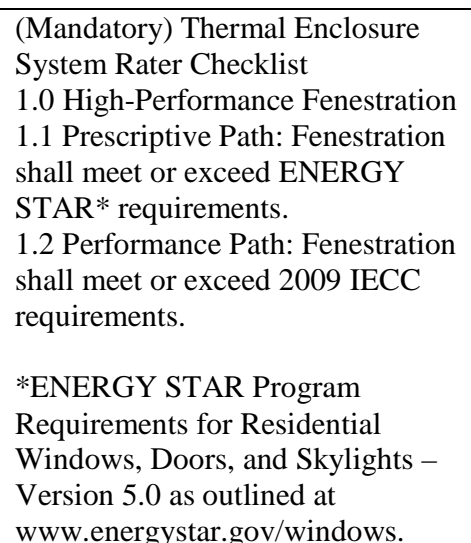 \\
\hline $\begin{array}{l}\text { Residential } \\
\text { Energy } \\
\text { Efficiency }\end{array}$ & Systems & Mandatory & $\begin{array}{l}403.1 \text { Controls. } \\
\text { 403.1.1 } \\
\text { Programmable } \\
\text { thermostat. }\end{array}$ & $\begin{array}{l}\text { At least one thermostat shall be } \\
\text { provided for each separate } \\
\text { heating and cooling system. } \\
\text { 403.1.1. Programmable } \\
\text { thermostat. Where the primary } \\
\text { heating system is a forced-air } \\
\text { furnace, at least one thermostat } \\
\text { per dwelling unit shall be } \\
\text { capable of controlling the } \\
\text { heating and cooling system on a } \\
\text { daily schedule to maintain } \\
\text { different temperature set points } \\
\text { at different times of the day. This } \\
\text { thermostat shall include the }\end{array}$ & $\begin{array}{l}703.4 \text { HVAC equipment efficiency } \\
\text { (Optional, Prescriptive path) } \\
\text { 703.4.10 An ENERGY STAR, or } \\
\text { equivalent, programmable thermostat is } \\
\text { installed to control each heating and } \\
\text { cooling zone. } \\
\text { 705.1 Energy consumption control. } \\
\text { (Optional) } \\
\text { A while building or whole dwelling unit } \\
\text { device is installed that controls or } \\
\text { monitors energy consumption. } \\
\text { (1) programmable communicating } \\
\text { thermostat } \\
\text { (2) Energy-monitoring device }\end{array}$ & $\begin{array}{l}\text { EA 6: Space Heating and Cooling Equipment } \\
\text { - Prescriptive Path } \\
\text { Prerequisite 6.1 (Mandatory). Good HVAC } \\
\text { Design and Installation. Meet each of the } \\
\text { following requirements... } \\
\text { c) Install ENERGY STAR labeled } \\
\text { programmable thermostat (except heat } \\
\text { pumps and hydronic systems). } \\
\\
\text { Update (1/1/10): To meet EA 6.1(c), } \\
\text { programmable thermostats are no longer } \\
\text { required to be ENERGY STAR labeled. }\end{array}$ & $\begin{array}{l}\text { Prescriptive Path: Energy Star qualified } \\
\text { thermostat (except for zones with radiant } \\
\text { heat). }\end{array}$ & $\begin{array}{l}\text { (Recommended) National Program } \\
\text { Requirements } \\
\text { Programmable thermostat shall be } \\
\text { installed unless thermostat controls a } \\
\text { zone with electric radiant heat, for } \\
\text { which a manual thermostat is allowed }\end{array}$ & $\begin{array}{l}\text { (Mandatory) National Program } \\
\text { Requirements } \\
\text { Programmable thermostat shall be } \\
\text { installed unless thermostat controls } \\
\text { a zone with electric radiant heat, } \\
\text { for which a manual thermostat is } \\
\text { allowed. }\end{array}$ \\
\hline
\end{tabular}




\begin{tabular}{|c|c|c|c|c|c|c|c|c|c|}
\hline Category & Topic & $\begin{array}{l}\text { Requireme } \\
\text { nt category }\end{array}$ & $\begin{array}{c}\text { IECC } \\
\text { Requirement } \\
\text { Reference }\end{array}$ & IECC 2009 & ICC-700 & LEED for Homes & ES2 & ES2.5 & ES3 \\
\hline & & & & $\begin{array}{l}\text { capability to set back or } \\
\text { temporarily operate the system to } \\
\text { maintain zone temperatures } \\
\text { down to } 55^{\circ}\left(13^{\circ} \mathrm{C}\right) \text { or up to } \\
85^{\circ} \mathrm{F}\left(25^{\circ} \mathrm{C}\right) \text {. The thermostat } \\
\text { shall initially be programmed } \\
\text { with a heating temperature set } \\
\text { point no higher than } 70^{\circ} \mathrm{F}\left(21^{\circ} \mathrm{C}\right) \\
\text { and a cooling temperature set } \\
\text { point no lower than } 78^{\circ} \mathrm{F}\left(26^{\circ} \mathrm{C}\right) \text {. }\end{array}$ & (3) energy management control system & & & & \\
\hline $\begin{array}{l}\text { Residential } \\
\text { Energy } \\
\text { Efficiency }\end{array}$ & Systems & Mandatory & $\begin{array}{l}\text { 403.1 Controls. } \\
\text { 403.1.2 Heat } \\
\text { pump } \\
\text { supplementary } \\
\text { heat. }\end{array}$ & $\begin{array}{l}\text { Heat pumps having } \\
\text { supplementary electric-resistance } \\
\text { heat shall have controls that, } \\
\text { except during defrost, prevent } \\
\text { supplemental heat operation } \\
\text { when the heat pump compressor } \\
\text { can meet the heating load. }\end{array}$ & $\begin{array}{l}\text { 703.4 HVAC equipment efficiency } \\
\text { (Optional, Prescriptive path) } \\
\text { 703.4.4 Heat pumm heating efficiency is } \\
\text { in accordance with Table 703.4.4. } \\
\text { Refrigerant charge is verified for } \\
\text { compliance with manufacturer's } \\
\text { instructions. } \\
\text { Zones } 5-9 \text { require consideration for use } \\
\text { of resistance heat in cold climates when } \\
\text { installing a heat pump. }\end{array}$ & $\begin{array}{l}\text { EA 6: Space Heating and Cooling Equipment } \\
\text { - Prescriptive Path } \\
\text { If a heat pump is installed with a } \\
\text { programmable thermostat, the thermostat } \\
\text { must be equipped with adaptive recovery. } \\
\text { This technology enables the heating } \\
\text { equipment to gradually adjust when the } \\
\text { thermostat setting changes, preventing } \\
\text { overdependence on the less efficient backup } \\
\text { heating system. }\end{array}$ & & $\begin{array}{l}\text { (Recommended) HVAC System } \\
\text { Quality Installation Contractor } \\
\text { Checklist } \\
\text { 18. For homes with heat pumps, the } \\
\text { thermostat shall have "Adaptive } \\
\text { Recovery" technology to prevent the } \\
\text { excessive use of electric back-up } \\
\text { heating. }\end{array}$ & $\begin{array}{l}\text { (Mandatory) HVAC System } \\
\text { Quality Installation Contractor } \\
\text { Checklist } \\
\text { 18. For homes with heat pumps, } \\
\text { the thermostat shall have "Adaptive } \\
\text { Recovery" technology to prevent } \\
\text { the excessive use of electric back- } \\
\text { up heating. }\end{array}$ \\
\hline $\begin{array}{c}\text { Residential } \\
\text { Energy } \\
\text { Efficiency }\end{array}$ & Systems & Prescriptive & $\begin{array}{l}\text { 403.2 Ducts. } \\
\text { 403.2.1.1 } \\
\text { Insulation. }\end{array}$ & $\begin{array}{l}\text { Supply ducts in attics shall be } \\
\text { insulated to a minimum of R-8. } \\
\text { All other ducts shall be insulated } \\
\text { to a minimum of R-6. } \\
\text { Exception: Ducts or portions } \\
\text { thereof located completely inside } \\
\text { the building thermal envelope. }\end{array}$ & $\begin{array}{l}\text { 704.4 Ducts (Optional). } \\
\text { 704.4.2 Space heating is provided by a } \\
\text { system that does not include air ducts. } \\
\text { 704.4.3 Space cooling is provided by a } \\
\text { system that does not include air ducts. }\end{array}$ & $\begin{array}{l}\text { EA 5: Heating and Cooling Distribution } \\
\text { System - Prescriptive Path } \\
\text { A. Forced-Air Systems } \\
\text { Prerequisite } 5.1 \text { Reduced Distribution Losses } \\
\text { (Mandatory). Meet the following } \\
\text { requirements...c) use at least R-6 insulation } \\
\text { around ducts in unconditioned spaces. }\end{array}$ & $\begin{array}{l}\text { (Mandatory) Thermal Bypass Inspection } \\
\text { Checklist } \\
\text { 4.0 Shafts. Openings to unconditioned } \\
\text { space are fully sealed with solid blocking } \\
\text { or flashing and any remaining gaps are } \\
\text { sealed with caulk or foam (provide fire- } \\
\text { rated collars and caulking where } \\
\text { required). } \\
\text { Performance Path: Leakage must be } \leq 6 \\
\text { cfm outdoors / } 100 \text { sq. ft. Prescriptive } \\
\text { Path Leakage: } \leq 4 \text { cfm to outdoors / } 100 \\
\text { sq. ft. ; and R- } 6 \text { min. insulation on ducts } \\
\text { in unconditioned spaces. }\end{array}$ & $\begin{array}{l}\text { (Recommended) HVAC System } \\
\text { Quality Installation Contractor } \\
\text { Checklist } \\
3.0 \text { Duct insulation- Applies to all } \\
\text { heating, cooling, supply ventilation, } \\
\text { and pressure balancing ducts. } \\
\text { 3.1 All connections to trunk ducts in } \\
\text { unconditioned space are insulated. } \\
\text { 3.2 Prescriptive Path: Supply ducts in } \\
\text { unconditioned attic have insulation } \geq \\
\text { R-8. Performance Path: Supply ducts } \\
\text { in unconditioned space have } \\
\text { insulation } \geq \text { R- } 3 \text {. 3.3 All other supply } \\
\text { ducts and all return ducts in } \\
\text { unconditioned space have insulation } \\
\geq \text { R-6. }\end{array}$ & $\begin{array}{l}\text { (Mandatory) HVAC System } \\
\text { Quality Installation Contractor } \\
\text { Checklist } \\
\text { 3.0 Duct insulation- Applies to all } \\
\text { heating, cooling, supply } \\
\text { ventilation, and pressure balancing } \\
\text { ducts. } \\
3.1 \text { All connections to trunk ducts } \\
\text { in unconditioned space are } \\
\text { insulated. } \\
3.2 \text { Prescriptive Path: Supply ducts } \\
\text { in unconditioned attic chave } \\
\text { insulation } \geq \text { R-8. Performance } \\
\text { Path: Supply ducts in } \\
\text { unconditioned space have } \\
\text { insulation } \geq R-6.3 .3 \text { All other } \\
\text { supply ducts and all return ducts in } \\
\text { unconditioned space have } \\
\text { insulation } \geq R-6 \text {. }\end{array}$ \\
\hline \begin{tabular}{|l|} 
Residential \\
Energy \\
Efficiency
\end{tabular} & Systems & Mandatory & $\begin{array}{l}\text { 403.2 Ducts. } \\
\text { 403.2.2. } \\
\text { Sealing. }\end{array}$ & $\begin{array}{l}\text { All ducts, air handlers, filter } \\
\text { boxes and building cavities used } \\
\text { as ducts shall be sealed. Joints } \\
\text { and seams shall comply with } \\
\text { Section M1601.4.1 of the } \\
\text { International Residential Code. }\end{array}$ & $\begin{array}{l}\text { 701.4.2 Duct systems (Mandatory). } \\
\text { 701.4.2.1 Ducts are sealed with tape } \\
\text { complying with UL 181, mastic, gaskets, } \\
\text { or an approved system as required by the } \\
\text { IRC, Section M1601.3.1, or IMC, Section } \\
\text { 603.9, to reduce leakage. }\end{array}$ & & $\begin{array}{l}\text { (Mandatory) Thermal Bypass Inspection } \\
\text { Checklist } \\
\text { 4.0 Shafts. Openings to unconditioned } \\
\text { space are fully sealed with solid blocking } \\
\text { or flashing and any remaining gaps are } \\
\text { sealed with caulk or foam (provide fire- } \\
\text { rated collars and caulking where } \\
\text { required). }\end{array}$ & $\begin{array}{l}\text { (Mandatory) Program V2.5 } \\
\text { Requirements: } \\
\text { Duct leakage to outdoors is } \\
\text { maintained at the v2 levels and shall } \\
\text { not exceed the following limits: } \\
\text { o } 4 \text { CFM / } 100 \text { sq ft of conditioned } \\
\text { floor area for the prescriptive path } \\
\text { o } 6 \text { CFM / } 100 \text { sp ft of conditioned } \\
\text { floor area for the performance path } \\
\text { No limit on total duct leakage is } \\
\text { imposed. }\end{array}$ & $\begin{array}{l}\text { (Mandatory) 14. For all homes that } \\
\text { have less than 1,200 sq ft of } \\
\text { conditioned floor area (CFA), total } \\
\text { measured duct leakage shall be }<8 \\
\text { CFM2 } 2 \text { per } 100 \text { sq. ft. of CFA and } \\
\text { measured duct leakage to outdoors } \\
\text { shall be }<5 \text { CFM25 per } 100 \text { sq. ft. } \\
\text { of CFA. } \\
15 \text {. If total duct leakage is }<4 \\
\text { CFM25 per } 100 \text { sq. ft. of } \\
\text { conditioned floor area, or }<5 \\
\text { CFM25 per } 100 \text { sq. ft. of } \\
\text { conditioned floor area for homes } \\
\text { that have less than } 1,200 \text { sq. ft. of } \\
\text { conditioned floor area, then } \\
\text { leakage to outdoors need not be } \\
\text { tested. }\end{array}$ \\
\hline $\begin{array}{c}\text { Residential } \\
\text { Energy } \\
\text { Efficiency }\end{array}$ & Systems & Mandatory & $\begin{array}{l}403.2 \text { Ducts. } \\
403.2 .2 \\
\text { Sealing. (1-2) }\end{array}$ & $\begin{array}{l}\text { Duct tightness shall be verified } \\
\text { by either of the following: } \\
\text { 1. Post-construction test: } \\
\text { Leakage to outdoors shall be less } \\
\text { than or equal to } 8 \mathrm{cfm}(\mathrm{fm} 2 \mathrm{(26.5} \\
\mathrm{L} / \mathrm{min}) \text { per } 100 \mathrm{ft2}(\mathrm{g} .29 \mathrm{~m} 2) \text { of } \\
\text { conditioned floor area or a total } \\
\end{array}$ & $\begin{array}{l}704.6 \text { Installation and performance } \\
\text { verification. (Optional) } \\
704.62 .2 .2 \text { The entire central HVAC duct } \\
\text { system, including air handlers and } \\
\text { register boots, is tested for leakage at a } \\
\text { pressure differential of } 0.1 \text { inches w.g. } \\
\text { (25 Pa). The maximum leakage as a. }\end{array}$ & $\begin{array}{l}\text { EA 5: Heating and Cooling Distribution } \\
\text { System - Prescriptive Path } \\
\text { A. Forceed-Air Systems } \\
\text { Prerequisite } 5.1 \text { Reduced Distribution Losses } \\
\text { (Mandatory). Meet the following } \\
\text { requirements...a) Limitit duct air leakage rate } \\
\text { to outside the conditioned envelope. The }\end{array}$ & $\begin{array}{l}\text { Performance Path: Ducts must be sealed } \\
\text { and tested to be } \leq 6 \text { ctm outdoors / } 100 \\
\text { sq. ft of conditioned floor area, as } \\
\text { determined and documented by a } \\
\text { RESNET- certified rater using a } \\
\text { RESNET- approved testing protocol. If } \\
\text { total duct leakage is } \leq 6 \mathrm{cfm} \text { to outdoors / }\end{array}$ & $\begin{array}{l}\text { (Mandatory) Program V2.5 } \\
\text { Requirements: } \\
\text { Duct leakage to outdoors is } \\
\text { maintained at the v2 levels and shall } \\
\text { not exceed the following limits: } \\
\text { o } 4 \text { CFM / } 100 \text { sq ft of conditioned } \\
\text { floor area for the prescriptive path }\end{array}$ & $\begin{array}{l}\text { (Mandatory) 14. For all homes that } \\
\text { have less than } 1,200 \text { sq ft of } \\
\text { conditioned floor area (CFA), total } \\
\text { measured duct leakage shall be }<8 \\
\text { CFM25 per } 100 \text { sq. ft. of CFA and } \\
\text { measured duct leakage to outdoors } \\
\text { shall be }<5 \text { CFM25 per } 100 \text { sq. ft. }\end{array}$ \\
\hline
\end{tabular}




\begin{tabular}{|c|c|c|c|c|c|c|c|c|c|}
\hline Category & Topic & $\begin{array}{l}\text { Requireme } \\
\text { nt category }\end{array}$ & $\begin{array}{c}\text { IECC } \\
\text { Requirement } \\
\text { Reference }\end{array}$ & IECC 2009 & ICC-700 & LEED for Homes & ES2 & ES2.5 & ES3 \\
\hline & & & & 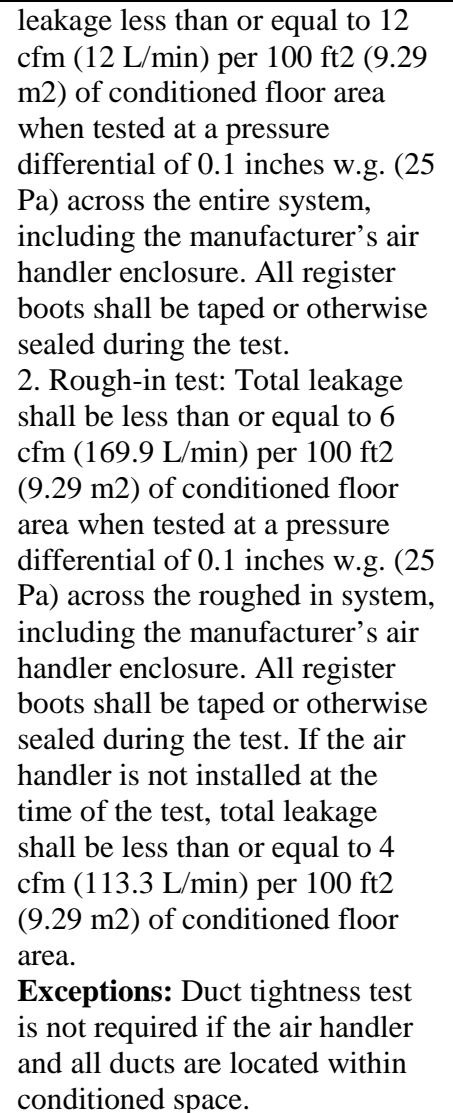 & $\begin{array}{l}\text { percent of the system design flow rate is } \\
\text { in accordance with the following: } \\
\text { (1) } 6 \text { percent for ductwork entirely } \\
\text { outside the building's thermal envelope } \\
\text { (2) } 6 \text { percent for ductwork entirely inside } \\
\text { the building's thermal envelope } \\
\text { (3) } 6 \text { percent for ductwork both inside } \\
\text { and outside the building's thermal } \\
\text { envelope }\end{array}$ & $\begin{array}{l}\text { tested duct leakage rate must be }<=4.0 \mathrm{cfm} \\
\text { at } 25 \text { Pascals per } 100 \text { square feet of } \\
\text { conditioned floor area (for each installed } \\
\text { system), verified by the energy rater. Testing } \\
\text { is waived if the home meets EA } 5.3 \text { (b) or } \\
\text { (c). }\end{array}$ & $\begin{array}{l}100 \text { sq. ft. of conditioned floor area, then } \\
\text { leakage to outdoors does not need to be } \\
\text { tested. Duct leakage testing can be } \\
\text { waived if all ducts and air handling } \\
\text { equipment are located in conditioned } \\
\text { space (i.e., within the home's air and } \\
\text { thermal barriers) AND the envelope } \\
\text { leakage has been tested to be } \leq 3 \text { ACH } 0 \\
\text { of } \leq 0.25 \text { CFM } 50 \text { per so. ff. of the } \\
\text { building envelope. Note that mechanical } \\
\text { ventilition will be required in this } \\
\text { situation. } \\
\text { Prescriptive Path: Leakage: } \leq 4 \text { cfin to } \\
\text { outdoors } 100 \text { sq. ft.; and R- } 6 \text { min. } \\
\text { insulation on ducts in unconditioned } \\
\text { spaces. }\end{array}$ & $\begin{array}{l}\text { o } 6 \text { CFM / } 100 \mathrm{sq} \mathrm{ft} \text { of conditioned } \\
\text { floor area for the performance path } \\
\text { No limit on total duct leakage is } \\
\text { imposed. }\end{array}$ & $\begin{array}{l}\text { of CFA. } \\
\text { 15. If total duct leakage is }<4 \\
\text { CFM25 per } 100 \text { sq. ft. of } \\
\text { conditioned floor area, or }<5 \\
\text { CFM25 per } 100 \text { sq. } \\
\text { conditioned floor area for homes } \\
\text { that have less than } 1,200 \text { sq. ft. of } \\
\text { conditioned floor area, then } \\
\text { leakage to outdoors need not be } \\
\text { tested. }\end{array}$ \\
\hline $\begin{array}{l}\text { Residential } \\
\text { Energy } \\
\text { Efficiency }\end{array}$ & Systems & Mandatory & $\begin{array}{l}\text { 403.2 Ducts. } \\
\text { 403.2.3 } \\
\text { Building } \\
\text { cavities. }\end{array}$ & $\begin{array}{l}\text { Building framing cavities shall } \\
\text { not be used as supply ducts. }\end{array}$ & $\begin{array}{l}\text { 701.4.2 Duct Systems (Mandatory). } \\
\text { 701.4.2.2 Building cavities are not used } \\
\text { as supply ducts. }\end{array}$ & $\begin{array}{l}\text { EA 5: Heating and Cooling Distribution } \\
\text { System - Prescriptive Path } \\
\text { A. Forced-Air Systems } \\
\text { Prerequisite 5.1 Reduced Distribution Losses } \\
\text { (Mandatory). Meet the following } \\
\text { requirements....b) Do not install lucts in } \\
\text { exterior walls unless extra insulation is added } \\
\text { to maintain the overall UA for an exterior } \\
\text { wall without ducts. Ducts may be run inside } \\
\text { interior wall cavities but must be fully ducted } \\
\text { (i.e., do not use the wall cavity as the duct). }\end{array}$ & $\begin{array}{l}\text { EPA recommends, but does not require, } \\
\text { locating ducts within the home's } \\
\text { conditioned space (i.e., inside the air and } \\
\text { thermal barriers), and using a minimum } \\
\text { of R-4 insulation for ducts inside the } \\
\text { conditioned space to prevent } \\
\text { condensation. }\end{array}$ & $\begin{array}{l}\text { (Recommended) HVAC System } \\
\text { Quality Installation Contractor } \\
\text { Checklist } \\
\text { 2.0 Duct Quality Installation- Applies } \\
\text { to all heating, cooling, ventilation, } \\
\text { exhaust, and pressure balancing } \\
\text { ducts. } 2.5 \text { Building cavities not used } \\
\text { as supply or return ducts unless they } \\
\text { meet items s.2, 3.3, 4.1, and } 4.2 \text { of } \\
\text { this checklist. } \\
3.2 \text { Prescriptive Path: Supply duct in } \\
\text { unconditioned attic have insulation } \geq \\
\text { R-8. Performance Path: Supply ducts } \\
\text { in unconditioned attic space have } \\
\text { insulation } \geq R-6.63 .3 \text { All other supply } \\
\text { ducts and all return ducts in } \\
\text { unconditioned space have insulation } \\
\geq R-6.4 .1 \text { Total Rater- measured duct } \\
\text { leakage } \leq 6 \text { CFM25 per } 100 \text { sq. ft. of } \\
\text { conditioned floor area. } 4.2 \text { Rater- } \\
\text { measured duct leakage to outdoors } \leq 4 \\
\text { CFM25 per } 100 \text { sq. ft. of conditioned } \\
\text { floor area. }\end{array}$ & $\begin{array}{l}\text { (Mandatory) HVAC System } \\
\text { Quality Installation Contractor } \\
\text { Checklist } \\
\text { 2.0 Duct Quality Installation- } \\
\text { Applies to all heating, cooling, } \\
\text { ventilation, exhaust, and pressure } \\
\text { balancing ducts. } 2.5 \text { Building } \\
\text { cavities not used as supply or } \\
\text { return nucts unless they meet items } \\
3.2,3.3,4.1, \text { and } 4.2 \text { of this } \\
\text { checklist. } \\
3.2 \text { Prescriptive Path: Supply duct } \\
\text { in unconditioned attic have } \\
\text { insulation } \geq R-8 \text {. Performance } \\
\text { Path: Supply ducts in } \\
\text { unconditioned attic space have } \\
\text { insulation } \geq R-6.3 .3 \text { All other } \\
\text { supply ducts and all return ducts in } \\
\text { unconditioned space have } \\
\text { insulation } \geq R-6.4 .1 \text { Total Rater- } \\
\text { measured duct leakage } \leq 6 \text { CFMM25 } \\
\text { per } 100 \text { sq. ft. of conditioned floor } \\
\text { area. } 4.2 \text { Rater-measured duct } \\
\text { leakage to outdoors } 4 \text { CFM25 per } \\
100 \text { sq. ft. of conditioned floor } \\
\text { area. }\end{array}$ \\
\hline 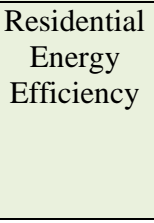 & $\begin{array}{l}\text { Systems } \\
\end{array}$ & Mandatory & $\begin{array}{l}403.3 \\
\text { Mechanical } \\
\text { system piping } \\
\text { insulation. }\end{array}$ & $\begin{array}{l}\text { Mechanical system piping } \\
\text { capable of carrying fluids above } \\
105^{\circ} \mathrm{F}\left(41^{\circ} \mathrm{C}\right) \text { or beloww5 } \\
\left(13^{\circ} \mathrm{F}\right. \\
\text { minimum of } \mathrm{R}-3 \text {. } 3 \text {. }\end{array}$ & & $\begin{array}{l}\text { EA 6: Space Heating and Cooling Equipment } \\
\text { - Prescriptive Path } \\
\text { Credit 6.3 (Optional). Very High-Efficiency } \\
\text { HVAC. Design and install HVAC } \\
\text { equipment that is substantially better than the } \\
\text { equipment required by the ENERGY STAR }\end{array}$ & & - & - \\
\hline
\end{tabular}




\begin{tabular}{|c|c|c|c|c|c|c|c|c|c|}
\hline Category & Topic & $\begin{array}{l}\text { Require } \\
\text { nt category }\end{array}$ & $\begin{array}{c}\text { IECC } \\
\text { Requirement } \\
\text { Reference }\end{array}$ & IECC 2009 & ICC-700 & LEED for Homes & ES2 & ES2.5 & ES3 \\
\hline & & & & & & $\begin{array}{l}\text { Builder Option Package (Table 1). Any } \\
\text { piping designed as part of a heat pump } \\
\text { system to carry water that is well above (or } \\
\text { below) the thermostatic temperature settings } \\
\text { in the home must have R-4 insulation or } \\
\text { greater. }\end{array}$ & & & \\
\hline $\begin{array}{l}\text { Residential } \\
\text { Energy } \\
\text { Efficiency }\end{array}$ & $\begin{array}{l}\text { Systems } \\
\end{array}$ & Mandatory & $\begin{array}{l}403.4 \\
\text { Circulating hot } \\
\text { water systems. }\end{array}$ & $\begin{array}{l}\text { All circulating service hot water } \\
\text { piping shall be insulated to at } \\
\text { least -2.2. Circulating hot water } \\
\text { systems shall include an } \\
\text { automatic or readily accessible } \\
\text { manual switth that can turn off } \\
\text { the hot water circulating pump } \\
\text { when the system is not in use. }\end{array}$ & $\begin{array}{l}703.5 \text { Water heating design, equipment, } \\
\text { and insulation (Optional, Prescriptive } \\
\text { path). } \\
\text { 703.5.4 Insulating hot water pipes } \\
\text { 703.5.4.1 Hot water lines are insulated to } \\
\text { a minimum of R-4. }\end{array}$ & $\begin{array}{l}\text { EA 7: Water Heating } \\
\text { Credit 7.1 Efficient Hot Water Distribution } \\
\text { (Optional - - erformance Path)...Select one of } \\
\text { the following designs: } \\
\text { a) Structured plumbing system... } \\
\text { iv. The system must be designed with a push } \\
\text { button control in each fulll bathroom and the } \\
\text { kitchen and an automatic pump shut-off. } \\
\text { Credit } 7.2 \text { Pipe Insulation (Optional - } \\
\text { Prescriptive Path). All domestic hot water } \\
\text { piping shall have R-4 insulation. Insulation } \\
\text { shall be properly installed on all piping } \\
\text { elbows to adequately insulate the 90-degree } \\
\text { bend. }\end{array}$ & $\begin{array}{l}\text { (Mandatory) 1.0 Where requirements of } \\
\text { the local codes, manufacturers' } \\
\text { installation instructions, engineering } \\
\text { documents, or regional ENERGY STAR } \\
\text { programs overlap with the requirements } \\
\text { of these guidelines, EPA offers the } \\
\text { following guidance: } \\
\text { a. In cases where the overlapping } \\
\text { requirements exceed the ENERGY } \\
\text { STAR guidelines, these overlapping } \\
\text { requirements shall be met; }\end{array}$ & & \\
\hline $\begin{array}{l}\text { Residential } \\
\text { Energy } \\
\text { Efficiency }\end{array}$ & Systems & Mandatory & $\begin{array}{l}403.5 \\
\text { Mechanical } \\
\text { ventilation. }\end{array}$ & $\begin{array}{l}\text { Outdoor air intakes and exhausts } \\
\text { shall have automatic or gravity } \\
\text { dampers that close when the } \\
\text { ventilation system is not } \\
\text { operating. }\end{array}$ & 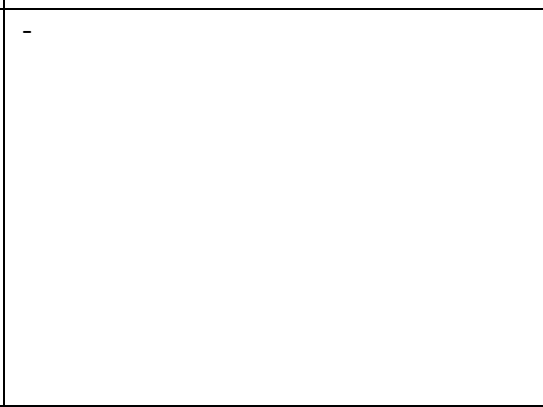 & & $\begin{array}{l}\text { (Mandatory) } 1.0 \text { Where requirements of } \\
\text { the local codes, manufacturers' } \\
\text { installation instructions, engineering } \\
\text { documents, or regional ENERGY STAR } \\
\text { programs overlap with the requirements } \\
\text { of these guidelines, EPA offers the } \\
\text { following guidance: } \\
\text { a. In cases where the overlapping } \\
\text { requirements exceed the ENERGY } \\
\text { STAR guidelines, these overlapping } \\
\text { requirements shall be met; }\end{array}$ & 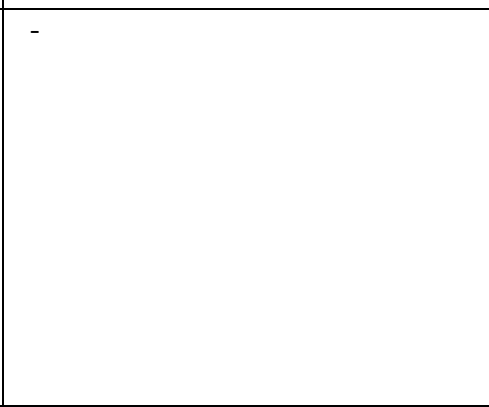 & - \\
\hline $\begin{array}{l}\text { Residential } \\
\text { Energy } \\
\text { Efficiency }\end{array}$ & Systems & Mandatory & $\begin{array}{l}403.6 \\
\text { Equipment } \\
\text { sizing. }\end{array}$ & $\begin{array}{l}\text { Heating and cooling equipment } \\
\text { shall be sized in accordance with } \\
\text { Section M1401.3 of the } \\
\text { International Residential Code. }\end{array}$ & $\begin{array}{l}\text { 701.4.1 HVAC systems (Mandatory). } \\
\text { 701.4.1.1 Space heating and cooling } \\
\text { systems/lequipment is sized according to } \\
\text { heating and cooling loads calculated } \\
\text { using ACCA Manual J, or equivalent. } \\
\text { 701.4.1.2 Where installed as a primary } \\
\text { heat source in the building, radiant or } \\
\text { hydronic space heating system is } \\
\text { designed using industryy-approved } \\
\text { guidelines (e.g., ACCA Manual J, } \\
\text { GAMA H-22, or an accredited design } \\
\text { professional's and manufacturer's } \\
\text { recommendations). }\end{array}$ & $\begin{array}{l}\text { EA 6: Space Heating and Cooling Equipment } \\
\text { - Prescriptive Path } \\
\text { Prerequisite 6.1 (Mandatory). Good HVAC } \\
\text { Design and Installation. Meet each of the } \\
\text { following requirements: } \\
\text { a) Design and size HVAC equipment } \\
\text { properly using ACCA Manual J, the } \\
\text { ASHRAE 2001 Handbook of Fundamentals, } \\
\text { or an equivalent computation procedure. } \\
\text { b) Install HVAC equipment that meets the } \\
\text { requirements of the ENERGY STAR for } \\
\text { Homes national Builder Option Package } \\
\text { (Table 1). } \\
\text { c) Install ENERGY STAR labeled } \\
\text { programmable thermostat (except heat } \\
\text { pumps and hydronic systems). } \\
\text { Credit } 6.2 \text { (Optional). High-Efficiency } \\
\text { HVAC. Design and install HVAC } \\
\text { equipment that is better than the equipment } \\
\text { required by the ENERGY STAR Builder } \\
\text { Option Package (Table 1) } \\
\text { OR } \\
\text { Credit 6.3 (OPtional). Very High-Efficiency } \\
\text { HVAC. Design and install HVAC } \\
\text { equipment that is substantially better than the } \\
\text { equipment required by the ENERGY STAR } \\
\text { Builder Option Package (Table 1). Any } \\
\text { piping designed as part of a heat pump } \\
\text { system to carry water that is well above (or } \\
\text { below) the thermostatic temperature settings } \\
\text { in the home must have R-4 insulation or } \\
\text { greater. }\end{array}$ & $\begin{array}{l}\text { (Mandatory) 3.0 Cooling equipment shall } \\
\text { be sized according to the latest editions } \\
\text { of ACCA Manuals J and S, ASHRAE } \\
\text { 2001 Handbooo of Fundamentals, or an } \\
\text { equivalent procedure. Maximum } \\
\text { oversizing limit for air conditioners and } \\
\text { heat pumps is } 15 \% \text { (with the exception of } \\
\text { heat pumps in Climate Zones } 5 \text { - 8, where } \\
\text { the maximum oversizing limit is } 25 \% \text {. } \\
\text { The following operating conditions shall } \\
\text { be used in the sizing calculations and } \\
\text { verified where reviewed by the rater: } \\
\text { Outdoor temperatures shall be the } 99.0 \% \\
\text { and 1.0\% design temperatures as } \\
\text { published in the ASHRAE Handbook of } \\
\text { Fundamentals for the home's location or } \\
\text { most representative city for which design } \\
\text { temperature data are available; Indoor } \\
\text { temperatures shall be 75 F for cooling } \\
\text { and 70 F for heating; Infiltration rate } \\
\text { shall be selected as “tight", or the } \\
\text { equivalent term. } \\
\text { In specifying equipment, the next } \\
\text { available size may be sued. In addition, } \\
\text { indoor and outdoor coils shall be matched } \\
\text { in accordance with ARI standards. }\end{array}$ & \begin{tabular}{|l} 
(Recommended) HVAC System \\
Quality Installation Contractor \\
Checklist \\
1.0 Heating and cooling loads shall \\
be calculated, equipment capacity \\
shall be selected, and duct systems \\
shall be sized according to the latest \\
editions of ACCA Manuals J, S, and \\
D, respectively, ASHRAE 2009 \\
Handbook of Fundamentals, or a \\
substantively equivalent procedure.
\end{tabular} & $\begin{array}{l}\text { (Mandatory) HVAC System } \\
\text { Quality Installation Contractor } \\
\text { Checklist } \\
1.0 \text { Heating and cooling loads shall } \\
\text { be calculated, equipment capacity } \\
\text { shall be selected, and duct systems } \\
\text { shall be sized according to the } \\
\text { latest editions of ACCA Manuals J, } \\
\text { S, and D, respectively, ASHRAE } \\
\text { 2009 Handobook of Fundamentals, } \\
\text { or a substantively equivalent } \\
\text { procedure. }\end{array}$ \\
\hline
\end{tabular}




\begin{tabular}{|c|c|c|c|c|c|c|c|c|c|}
\hline Category & Topic & $\begin{array}{l}\text { Requireme } \\
\text { nt category }\end{array}$ & $\begin{array}{c}\text { IECC } \\
\text { Requirement } \\
\text { Reference }\end{array}$ & IECC 2009 & ICC-700 & LEED for Homes & ES2 & ES2.5 & ES3 \\
\hline $\begin{array}{l}\text { Residential } \\
\text { Energy } \\
\text { Efficiency }\end{array}$ & Systems & Mandatory & $\begin{array}{l}403.7 \text { Systems } \\
\text { serving } \\
\text { multiple } \\
\text { dwelling units. }\end{array}$ & $\begin{array}{l}\text { Systems serving multiple } \\
\text { dwelling units shall comply with } \\
\text { Sections } 503 \text { and } 504 \text { in lieu of } \\
\text { Section } 403 \text {. }\end{array}$ & & & & & - \\
\hline $\begin{array}{c}\text { Residential } \\
\text { Energy } \\
\text { Efficiency }\end{array}$ & Systems & Mandatory & $\begin{array}{l}403.8 \text { Snow } \\
\text { melt system } \\
\text { controls. }\end{array}$ & $\begin{array}{l}\text { Snow- and ice-melting systems, } \\
\text { supplied through energy service } \\
\text { to the building, shall include } \\
\text { automatic controls capable of } \\
\text { shutting of the system when the } \\
\text { pavement temperature is above } \\
\text { 50 }{ }^{\circ} \text {, and no precipitation is } \\
\text { falling and an automatic or } \\
\text { manual control that will allow } \\
\text { shutoff when the outdoor } \\
\text { temperature is above } 40^{\circ} \mathrm{F} \text {. }\end{array}$ & - & - & - & - & - \\
\hline $\begin{array}{c}\text { Residential } \\
\text { Energy } \\
\text { Efficiency }\end{array}$ & Systems & Mandatory & $\begin{array}{l}\text { 403.9 Pools. } \\
\text { 403.9.1 Pool } \\
\text { heaters. }\end{array}$ & $\begin{array}{l}\text { Pools shall be provided with } \\
\text { energy-conserving measures in } \\
\text { accordance with Sections } \\
\text { 403.9.1 through 403.9.3. } \\
\text { 403.9.1 Pool heaters. All pool } \\
\text { heaters shall be equipped with a } \\
\text { readily accessible on-off switch } \\
\text { to allow shutting off the heater } \\
\text { without adjusting the thermostat } \\
\text { setting. Pool heaters fired by } \\
\text { natural gas or LPG shall not have } \\
\text { continuously burning pilot lights. }\end{array}$ & - & - & - & - & - \\
\hline $\begin{array}{c}\text { Residential } \\
\text { Energy } \\
\text { Efficiency }\end{array}$ & Systems & Mandatory & $\begin{array}{l}\text { 403.9 Pools. } \\
\text { 403.9.2 Time } \\
\text { switches. }\end{array}$ & $\begin{array}{l}\text { Time switches that can } \\
\text { automatically turn off and on } \\
\text { heaters and pumps according to a } \\
\text { preset schedule shall be installed } \\
\text { on swimming pool heaters and } \\
\text { pumps. } \\
\text { Exceptions: } \\
\text { 1. Where public health standards } \\
\text { require 24-hour pump operation. } \\
\text { 2. Where pumps are required to } \\
\text { operate solar- and waste-heat- } \\
\text { recovery pool heating systems. }\end{array}$ & - & - & - & - & - \\
\hline $\begin{array}{c}\text { Residential } \\
\text { Energy } \\
\text { Efficiency }\end{array}$ & Systems & Mandatory & $\begin{array}{l}\text { 403.9 Pools. } \\
\text { 403.9.3 Pool } \\
\text { covers. }\end{array}$ & $\begin{array}{l}\text { Heated pools shall be equipped } \\
\text { with a vapor-retardant pool cover } \\
\text { on or at the water surface. Pools } \\
\text { heated to more than } 90^{\circ} \mathrm{F}\left(32^{\circ} \mathrm{C}\right) \\
\text { shall have a pool cover with a } \\
\text { minimum insulation value of } \mathrm{R}- \\
12 . \\
\text { Exception: Pools deriving over } \\
60 \text { percent of the energy for } \\
\text { heating from site-recovered } \\
\text { energy or solar energy source. }\end{array}$ & (a) & ( & t & ( & ( \\
\hline $\begin{array}{c}\text { Residential } \\
\text { Energy } \\
\text { Efficiency }\end{array}$ & $\begin{array}{l}\text { Electrical } \\
\text { Power and } \\
\text { Lighting } \\
\text { Systems }\end{array}$ & Prescriptive & $\begin{array}{l}\text { 404.1 Lighting } \\
\text { equipment. }\end{array}$ & $\begin{array}{l}\text { A minimum of } 50 \text { percent of the } \\
\text { lamps in permanently installed } \\
\text { lighting fixtures shall be high- } \\
\text { efficacy lamps. }\end{array}$ & $\begin{array}{l}\text { 704.2 Lighting and appliances } \\
704.2 .1 \text { Hard-wired lighting is in } \\
\text { accordance with one of the following: } \\
\text { (1) A minimum of } 50 \text { percent of the total } \\
\text { hard-wired lighting fixtures, or the bulbs } \\
\text { in those fixtures, qualilyy as ENERGY } \\
\text { STAR or equivalent. } \\
\text { (2) A minimum of } 50 \text { percent of the total } \\
\text { hard-wired lighting fixtures qualify as } \\
\text { ENERGY STAR or equivalent. } \\
\text { (3) A minimum of } 8 \text { percent of the } \\
\text { exterior lighting wattage has an } \\
\text { efficiency of } 40 \text { lumens per watt }\end{array}$ & $\begin{array}{l}\text { EA 8: Lighting - Prescriptive Path } \\
\text { Prerequisite 8.1 ENERGY STAR Lights } \\
\text { (Mandatory). Install at least four ENERGY } \\
\text { STAR labeled light fixtures or ENERGY } \\
\text { STAR labeled compact fluorescent light } \\
\text { bulbs (CFLs) in high-use rooms (kitchen, } \\
\text { dining room, living room, family room, } \\
\text { hallways). } \\
\text { Credit } 82.2 \text { Improved Lighting (Optional). } \\
\text { Select and install one or both of the } \\
\text { following measures: } \\
\text { a) Indoor lighting. Install three additional } \\
\text { ENERGGY STAR labeled light fixtures or }\end{array}$ & $\begin{array}{l}\text { Prescriptive Path: Five or more Energy } \\
\text { Star qualified appliances, light fixtures, } \\
\text { ceiling fans equipped with lighting } \\
\text { fixtures, water heaters, and/or ventilation } \\
\text { fans must be installed. Any combination } \\
\text { of Energy Star qualified products listed } \\
\text { may be installed to meet this } \\
\text { requirement.... Energy Star qualified } \\
\text { lighting fixtures installed in the following } \\
\text { locations shall not be counted. storage } \\
\text { rooms (e.g., closets, pantries, sheds), or } \\
\text { garages. }\end{array}$ & $\begin{array}{l}\text { Prescriptive Path: Energy Star } \\
\text { qualified CFLs or pini-based lighting } \\
\text { in 80\% of fixtures in RESNET- } \\
\text { defined Qualifying Light Fixture } \\
\text { Locations shall be installed. } \\
\text { (Alternate: Energy Star Advanced } \\
\text { Lighting Package). }\end{array}$ & $\begin{array}{l}\text { Prescriptive Path: ENERGY STAR } \\
\text { qualified CFLs or pin-based } \\
\text { lighting in } 80 \% \text { of fixtures in } \\
\text { RESNET-defined Qualifying Light } \\
\text { Fixture Locations shall be } \\
\text { installed. (Alternate: ENERGY } \\
\text { STAR Advanced Lighting } \\
\text { Package). }\end{array}$ \\
\hline
\end{tabular}




\begin{tabular}{|c|c|c|c|c|c|c|c|c|c|}
\hline Category & Topic & $\begin{array}{l}\text { Requireme } \\
\text { nt category }\end{array}$ & $\begin{array}{c}\text { IECC } \\
\text { Requirement } \\
\text { Reference }\end{array}$ & IECC 2009 & ICC-700 & LEED for Homes & ES2 & ES2.5 & ES3 \\
\hline & & & & & $\begin{array}{l}\text { minimum or be a solar-powered light } \\
\text { fixture. }\end{array}$ & $\begin{array}{l}\text { ENERGY STAR labeled compact } \\
\text { fluorescent light bulbs (CFLs) in high-use } \\
\text { rooms. } \\
\text { b) Exterior lighting. All exterior lighting } \\
\text { must have either motion sensor controls or } \\
\text { integrated photovoltaic cells. } \\
\text { OR } \\
\text { Credit } 8.3 \text { Advanced Lighting Package } \\
\text { (Optional). Install ENERGY STAR } \\
\text { Advanced Lighting Package...consists of a } \\
\text { minimum of 60\% ENERGY STAR qualified } \\
\text { hard-wired fixtures and } 100 \% \text { ENERGY } \\
\text { STAR-qualified ceiling fans (if any) OR } \\
\text { Install ENERGY STAR labeled lamps in } \\
\text { 80\% of the fixtures throughout the home. } \\
\text { ENERGY STAR labeled CFLs are } \\
\text { acceptable. All ceiling fans must be } \\
\text { ENERGY STAR labeled. }\end{array}$ & & & \\
\hline $\begin{array}{l}\text { Residential } \\
\text { Energy } \\
\text { Efficiency }\end{array}$ & $\begin{array}{l}\text { Simulated } \\
\text { Performance } \\
\text { Alternative }\end{array}$ & $\begin{array}{l}\text { Performance } \\
\end{array}$ & $\begin{array}{l}405.2 \\
\text { Mandatory } \\
\text { requirements. }\end{array}$ & $\begin{array}{l}\text { Compliance with this section } \\
\text { requires that the mandatory } \\
\text { provisions identifiedied in Section } \\
401.2 \text { be met. All supply and } \\
\text { return ducts not completely } \\
\text { inside the building thermal } \\
\text { envelope shall be insulated to a } \\
\text { minimum of R-6. }\end{array}$ & $\begin{array}{l}\text { 704.4 Ducts. } \\
704.4 .2 \text { Space heating is provided by a } \\
\text { system that does not include air ducts. } \\
\text { (15 points) } \\
704.4 .3 \text { Space cooling is provided by a } \\
\text { system that does not include air ducts. } \\
\text { (15 points) } \\
704.44 \text { Ductwork is in accordance with } \\
\text { all of the following: (12 points) } \\
\text { (1) Building cavities are not used as } \\
\text { return ductwork. } \\
\text { (2) Heating and cooling ducts and } \\
\text { mechanical equipment are installed } \\
\text { within the conditioned building space. } \\
\text { (3) Ductwork is not installed in exterior } \\
\text { walls. }\end{array}$ & $\begin{array}{l}\text { EA 5: Heating and Cooling Distribution } \\
\text { System - Prescriptive Path } \\
\text { A. Forced-Air Systems } \\
\text { Prerequisite } 5.1 \text { Reduced Distribution Losses } \\
\text { (Mandatory). Meet the following } \\
\text { requirements...c) use at least R-6 insulation } \\
\text { around ducts in unconditioned spaces. }\end{array}$ & - & $\begin{array}{l}\text { (Recommended) HVAC System } \\
\text { Quality Installation Contractor } \\
\text { Checklist } \\
3.0 \text { Duct insulation } 3.1 \text { All } \\
\text { connections to trunk ducts in } \\
\text { unconditioned space are insulated. } 3.3 \\
\text { All other supply ducts and all return } \\
\text { ducts in unconditioned space have } \\
\text { insulation } \geq \text { R-6 }\end{array}$ & $\begin{array}{l}\text { (Mandatory) HVAC System } \\
\text { Quality Installation Contractor } \\
\text { Checklist } \\
3.0 \text { Duct insulation } \\
3.1 \text { All connections to trunk ducts } \\
\text { in unconditioned space are } \\
\text { insulated. } \\
\text { 3.3 All other supply ducts and all } \\
\text { return ducts in unconditioned space } \\
\text { have insulation } \geq \text { R-6. }\end{array}$ \\
\hline $\begin{array}{l}\text { Residential } \\
\text { Energy } \\
\text { Efficiency }\end{array}$ & $\begin{array}{l}\text { Simulated } \\
\text { Performance } \\
\text { Alternative }\end{array}$ & Performance & $\begin{array}{l}405.3 \\
\text { Performance- } \\
\text { based } \\
\text { compliance. }\end{array}$ & 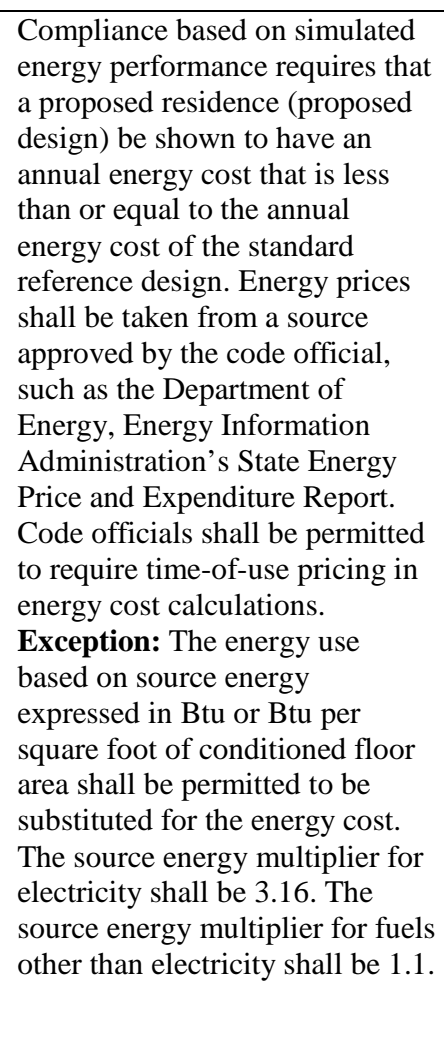 & $\begin{array}{l}\text { 702.2 Energy cost performance levels } \\
\text { (Performance Path). Energy efficiency } \\
\text { features are implemented to achieve } \\
\text { energy cost performance that exceeds the } \\
2006 \text { IECC by the following. A } \\
\text { documented analysis using software in } \\
\text { accordance with IECC, Section 404, or } \\
\text { 2006 IECC Section 506.2 through 506.5, } \\
\text { applied as defined in the } 2006 \text { IECC, is } \\
\text { required. } \\
\text { (1) } 15 \text { percent (Mandatory - minimum } \\
\text { requirement) } \\
\text { (2) } 30 \text { percent } \\
\text { (3) } 50 \text { percent } \\
\text { (4) } 60 \text { percent }\end{array}$ & 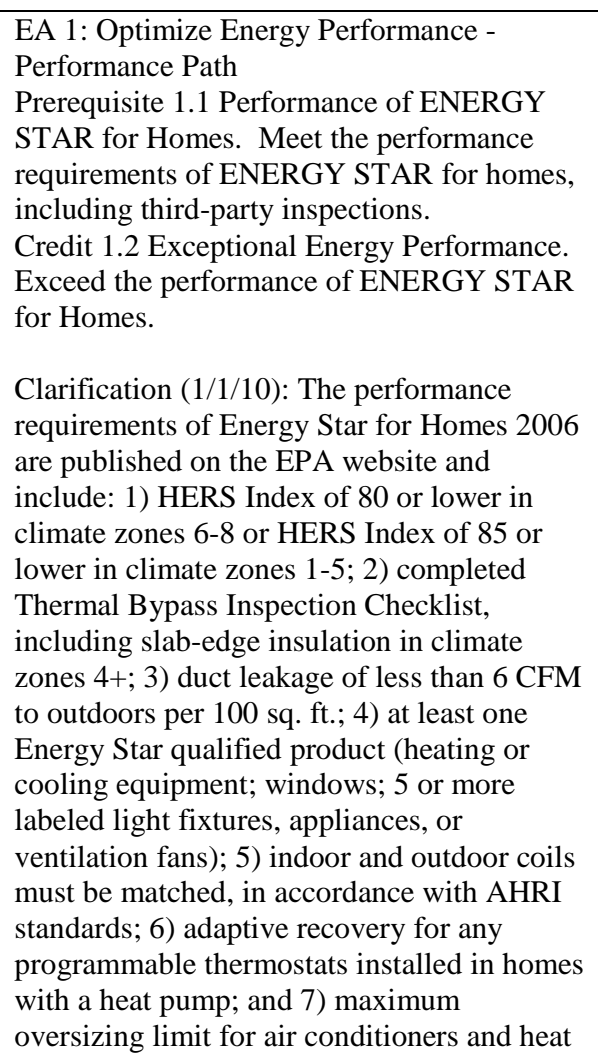 & $\begin{array}{l}\text { Compliance based on using a } \\
\text { performance approach to meet a HERS } \\
\text { Index of } 80 \text { in Climate Zones } 6 \text { - } 8 \text { and an } \\
85 \text { in Climate Zones } 1 \text { - } 5 \text {. }\end{array}$ & $\begin{array}{l}\text { National Program Requirements. } \\
\text { Performance Path: } \\
\text { 1.0 Determinine the ENERGY STAR } \\
\text { HERS Index Target, which is the } \\
\text { highest numerical HERS index value } \\
\text { that each rated home may achieve to } \\
\text { earn the ENERGY STAR. This target } \\
\text { shall be speififically determined for } \\
\text { each rated home by following the } \\
\text { steps outlined in the document titled, } \\
\text { "ENERGY STAR HERS Index } \\
\text { Target Procedure, Version } 3 \text { (Rev. } \\
\text { 02)", available on EPA"s Web site. } \\
\text { This procedure defines how to } \\
\text { configure the ENERGY STAR } \\
\text { Reference Design Home and } \\
\text { calculate its associated HERS index } \\
\text { value and then how to apply the } \\
\text { appropriate Size Adjustment Factor to } \\
\text { determine the ENERGY STAR } \\
\text { HERS Index Target. Note that EPA } \\
\text { will provide modified Mandatory } \\
\text { Requirements and ENERGY STAR } \\
\text { Reference Design specifications for } \\
\text { states with nenergy codes significantly } \\
\text { more rigorous than the 2009 IECC. } \\
\text { Once published, these modified } \\
\text { specificiations shall be used after a } \\
\text { specified transition period, typically }\end{array}$ & $\begin{array}{l}\text { National Program Requirements. } \\
\text { Performance Path } \\
\text { 1.0 Determinie the ENERGY } \\
\text { STAR HERS Index Target, which } \\
\text { is the highest numerical HERS } \\
\text { index value that each rated home } \\
\text { may achieve to earn the ENERGY } \\
\text { STAR. This target thall be } \\
\text { specifically detetermined for each } \\
\text { rated home by following the steps } \\
\text { outlined in the document titled, } \\
\text { "ENERGY STAR HERS Index } \\
\text { Target Procedure, Version } 3 \text { (Rev. } \\
\text { 02)", available on EPA"s Web site. } \\
\text { This procedure defines how to } \\
\text { configure the ENERGY STAR } \\
\text { Reference Design Home and } \\
\text { calculate its associated HERS } \\
\text { index value and then how to apply } \\
\text { the appropriate Size Adjustment } \\
\text { Factor to determine the ENERGY } \\
\text { STAR HERS Index Target. Note } \\
\text { that EPA will provide modified } \\
\text { Mandatory Requirements and } \\
\text { ENERGY STAR Reference Design } \\
\text { specifications for states with } \\
\text { energy codes significantly more } \\
\text { rigorous than the 2009 IIECC. Once } \\
\text { published, these modified }\end{array}$ \\
\hline
\end{tabular}




\begin{tabular}{|c|c|c|c|c|c|c|c|c|c|}
\hline Category & Topic & $\begin{array}{l}\text { Requireme } \\
\text { nt category }\end{array}$ & $\begin{array}{c}\text { IECC } \\
\text { Requirement } \\
\text { Reference }\end{array}$ & IECC 2009 & ICC-700 & LEED for Homes & ES2 & ES2.5 & ES3 \\
\hline & & & & & & $\begin{array}{l}\text { pumps is } 15 \% \text {, with the exception of heat } \\
\text { pumps in Climate Znones 5-8, where } \\
\text { maximum oversizing is 25\%). }\end{array}$ & & $\begin{array}{l}60 \text { days, to determine the ENERGY } \\
\text { STAR HERS Index Target in these } \\
\text { states. Note that this procecss shall be } \\
\text { completed manually by a Rater until a } \\
\text { version of the RESNET-accredited } \\
\text { software program used by the Rater } \\
\text { becomes available that automatically } \\
\text { configures the ENERGY STAR } \\
\text { Reference Design, calculates its } \\
\text { associated HERS index value, and } \\
\text { then applies the appropriate Size } \\
\text { Adjustment Factor to determine the } \\
\text { ENERGY STAR HERS Index } \\
\text { Target. Upon release of such a } \\
\text { version, Raters using that software } \\
\text { program shall have 60 days to begin } \\
\text { all new ratings with this updated } \\
\text { version. 2. Using the same RESNET- } \\
\text { accredited Home Energy Rating } \\
\text { software program, configure the } \\
\text { prefefred set of energy measures for } \\
\text { the rated home and verify that the } \\
\text { resulting HERS Index meets or } \\
\text { exceeds the ENERGY STAR HERS } \\
\text { Index Target, as determined in Step } 1 . \\
\text { Note that, regardless of the measures } \\
\text { selected, Mandatory Requirements } \\
\text { for All Qualified Homes in Exhibit } 2 \\
\text { are also required. Also note that items } \\
1.2 \text { and 2.1 of the Thermal Enclosure } \\
\text { System Rater checklist require that all } \\
\text { insulation, windows, doors, and } \\
\text { skylights meet or exceed 2009 IECC } \\
\text { requirements. }\end{array}$ & 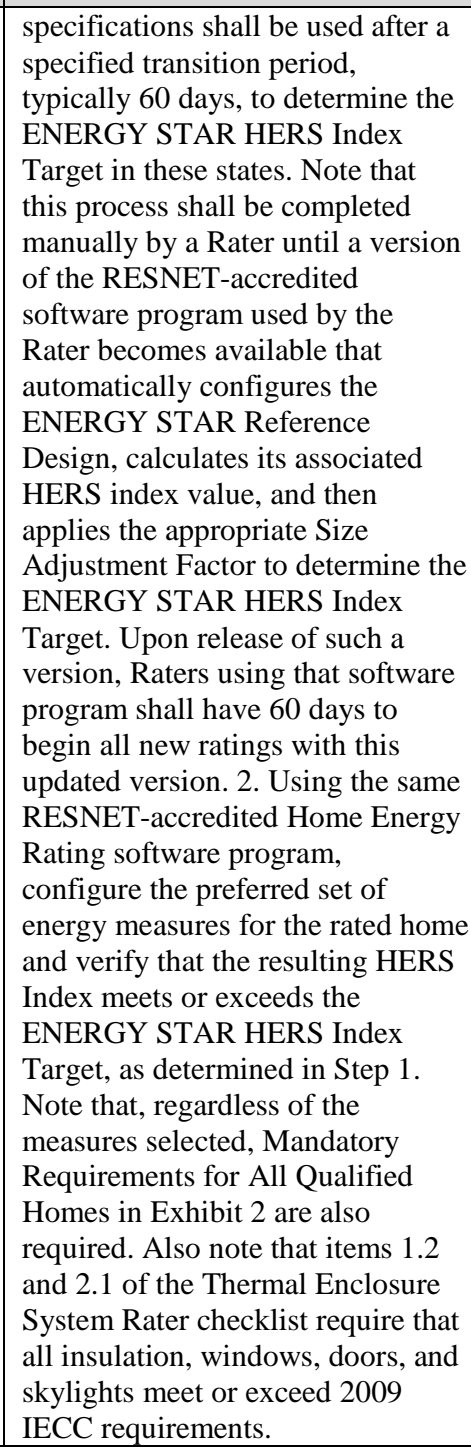 \\
\hline $\begin{array}{l}\text { Residential } \\
\text { Energy } \\
\text { Efficiency }\end{array}$ & \begin{tabular}{|l} 
Simulated \\
Performance \\
Alternative
\end{tabular} & Performance & $\begin{array}{l}405.4 \\
\text { Documentation. } \\
405.4 .1 \\
\text { Compliance } \\
\text { software tools. }\end{array}$ & $\begin{array}{l}\text { Documentation verifying that the } \\
\text { methods and accuracy of the } \\
\text { compliance software tools } \\
\text { conform to the provisions of this } \\
\text { section shall be provided to the } \\
\text { code official. }\end{array}$ & $\begin{array}{l}702.2 \text { Energy cost performance levels } \\
\text { (Performance Path). Energy efficiency } \\
\text { features are implemented to achieve } \\
\text { energy cost performance that exceeds the } \\
\text { 2006 IECC by the following. A } \\
\text { documented analysis using software in } \\
\text { accordance with IECC, Section 404, or } \\
\text { 2006 IECC Section 506.2 through 506.5, } \\
\text { applied as defined in the IECC, is } \\
\text { required. }\end{array}$ & & & - & - \\
\hline $\begin{array}{l}\text { Residential } \\
\text { Energy } \\
\text { Efficiency }\end{array}$ & \begin{tabular}{|l} 
Simulated \\
Performance \\
Alternative
\end{tabular} & Performance & $\begin{array}{l}405.4 \\
\text { Documentation. } \\
405.4 .2 \\
\text { Compliance } \\
\text { report. }\end{array}$ & $\begin{array}{l}\text { Compliance software tools shall } \\
\text { generate a report that documents } \\
\text { hat the proposed design } \\
\text { complies with Section } 405.3 \text {. }\end{array}$ & $\begin{array}{l}702.2 \text { Energy cost performance levels } \\
\text { (Performance Path). Energy efficiency } \\
\text { features are implemented to achieve } \\
\text { energy cost performance that exceeds the } \\
2006 \text { IECC by the following. A } \\
\text { documented analysis using software in } \\
\text { accordance with } 2006 \text { IECC, Section } \\
404 \text {, or } 2006 \text { IECC Section } 506.2 \text { through } \\
\text { 506.5, applied as defined in the } 2006 \\
\text { IECC, is required. }\end{array}$ & & & - & - \\
\hline $\begin{array}{l}\text { Residential } \\
\text { Energy } \\
\text { Efficiency }\end{array}$ & \begin{tabular}{|l|} 
Simulated \\
Performance \\
Alternative
\end{tabular} & Performance & $\begin{array}{l}405.4 \\
\text { Documentation. } \\
405.42\end{array}$ & $\begin{array}{l}\text { The compliance documentation } \\
\text { shall include the following } \\
\text { information: }\end{array}$ & $\begin{array}{l}702.2 \text { Energy cost performance levels } \\
\text { (Performance Path). Energy efficiency } \\
\text { features are immlemented to achieve }\end{array}$ & & & & \\
\hline
\end{tabular}




\begin{tabular}{|c|c|c|c|c|c|c|c|c|c|}
\hline Category & Topic & $\begin{array}{l}\text { Requireme } \\
\text { nt category }\end{array}$ & $\begin{array}{c}\text { IECC } \\
\text { Requirement } \\
\text { Reference } \\
\end{array}$ & IECC 2009 & ICC-700 & LEED for Homes & ES2 & ES2.5 & ES3 \\
\hline & & & $\begin{array}{l}\text { Compliance } \\
\text { report.(1) }\end{array}$ & $\begin{array}{l}\text { 1. Address or other identification } \\
\text { of the residence; }\end{array}$ & $\begin{array}{l}\text { energy cost performance that exceeds the } \\
\text { 2006 IICCC by the following. A } \\
\text { documented analysis using software in } \\
\text { accordance with } 2006 \text { IECC, Section } \\
404 \text {, o } 2006 \text { IECC Section } 506.2 \text { through } \\
\text { 506.5, applied as defined in the } 2006 \\
\text { IECC, is required. }\end{array}$ & & & & \\
\hline $\begin{array}{l}\text { Residential } \\
\text { Energy } \\
\text { Efficiency }\end{array}$ & \begin{tabular}{|l} 
Simulated \\
Performance \\
Alternative
\end{tabular} & Performance & $\begin{array}{l}405.4 \\
\text { Documentation. } \\
\text { 405.4.2 } \\
\text { Compliance } \\
\text { report.(2) }\end{array}$ & $\begin{array}{l}\text { The compliance documentation } \\
\text { shall include the following } \\
\text { information: } \\
\text { 2. An inspection checklist } \\
\text { documenting the building } \\
\text { component characteristics of the } \\
\text { proposed design as listed in } \\
\text { Table } 4005.5 .2(1) \text {. The inspection } \\
\text { checklist shall show results for } \\
\text { both the standard reference } \\
\text { design and the proposed design, } \\
\text { and shall document all inputs } \\
\text { entered by the user necessary to } \\
\text { reproduce the results; }\end{array}$ & $\begin{array}{l}\text { 702.2 Energy cost performance levels } \\
\text { (Performance Path). Energy efficiency } \\
\text { features are implemented to achieve } \\
\text { energy cost performance that exceeds the } \\
2006 \text { IECC by the following. A } \\
\text { documented analysis using software in } \\
\text { accordance with } 2006 \text { IECC, Section } \\
404 \text {, or } 2006 \text { IECC Section } 506.2 \text { through } \\
\text { 506.5, applied as defined in the } 2006 \\
\text { IECC, is required. }\end{array}$ & & - & - & - \\
\hline $\begin{array}{l}\text { Residential } \\
\text { Energy } \\
\text { Efficiency }\end{array}$ & \begin{tabular}{|l} 
Simulated \\
Performance \\
Alternative
\end{tabular} & Performance & $\begin{array}{l}405.4 \\
\text { Documentation. } \\
\text { 405.4.2 } \\
\text { Compliance } \\
\text { report.(3) }\end{array}$ & $\begin{array}{l}\text { The compliance documentation } \\
\text { shall include the following } \\
\text { information: } \\
\text { 3. Name of individual } \\
\text { completing the compliance } \\
\text { report; and }\end{array}$ & $\begin{array}{l}702.2 \text { Energy cost performance levels } \\
\text { (Performance Path). Energy efficiency } \\
\text { features are implemented to achieve } \\
\text { energy cost performance that exceeds the } \\
2006 \text { IECC by the following. A } \\
\text { documented analysis using software in } \\
\text { accordance with } 2006 \text { IIECC, Section } \\
404 \text {, or } 2006 \text { IECC Section } 506.2 \text { through } \\
506.5 \text {, applied as defined in the } 2006 \\
\text { IECC, is required. }\end{array}$ & & & & \\
\hline $\begin{array}{l}\text { Residential } \\
\text { Energy } \\
\text { Efficiency }\end{array}$ & \begin{tabular}{|l|} 
Simulated \\
Performance \\
Alternative \\
\end{tabular} & Performance & $\begin{array}{l}405.4 \\
\text { Documentation. } \\
\text { 405.4.2 } \\
\text { Compliance } \\
\text { report.(4) }\end{array}$ & $\begin{array}{l}\text { The compliance documentation } \\
\text { shall include the following } \\
\text { information: } \\
\text { 4. Name and version of the } \\
\text { compliance software etool. } \\
\text { Exception: Multiple } \\
\text { orientations. When an otherwise } \\
\text { identical building model is } \\
\text { offered in multiple orientations, } \\
\text { compliance for any orientation } \\
\text { shall be permitted by } \\
\text { documenting that the building } \\
\text { meets the performance } \\
\text { requirements in each of the four } \\
\text { cardinal (north, east, south and } \\
\text { west) orientations. }\end{array}$ & $\begin{array}{l}702.2 \text { Energy cost performance levels } \\
\text { (Performance Path). Energy efficiency } \\
\text { features are implemented to achieve } \\
\text { energy cost performance that exceeds the } \\
2006 \text { IECC by the following. A } \\
\text { documented analysis using software in } \\
\text { accordance with IECC, Section } 404, \text { or } \\
2006 \text { IECC Section } 506.2 \text { through } 506.5 \text {, } \\
\text { applied as defined in the } 2006 \text { IECC, is } \\
\text { required. }\end{array}$ & & & & \\
\hline $\begin{array}{l}\text { Residential } \\
\text { Energy } \\
\text { Efficiency }\end{array}$ & \begin{tabular}{|l} 
Simulated \\
Performance \\
Alternative
\end{tabular} & Performance & $\begin{array}{l}405.4 \\
\text { Documentation. } \\
\text { 405.4.3 } \\
\text { Additional } \\
\text { documentation. }\end{array}$ & $\begin{array}{l}\text { The code official shall be } \\
\text { permitted to require the } \\
\text { following documents: } \\
\text { 1. Documentation of the building } \\
\text { component characteristics of the } \\
\text { standard reference design. } \\
\text { 2. A certification signed by the } \\
\text { builder providing the building } \\
\text { component characteristics of the } \\
\text { proposed design as given in } \\
\text { Table } 405.5 .2(1) . \\
\text { 3. Documentation of the actual } \\
\text { values used in the software } \\
\text { calculations for the proposed } \\
\text { design. }\end{array}$ & $\begin{array}{l}702.2 \text { Energy cost performance levels } \\
\text { (Performance Path). Energy efficiency } \\
\text { features are implemented to achieve } \\
\text { energy cost performance that exceeds the } \\
2006 \text { IECC by the following. A } \\
\text { documented analysis using software in } \\
\text { accordance with 2006 IECC, Section } \\
404 \text {, or } 2006 \text { IECC Section } 506.2 \text { through } \\
\text { 506.5, applied as defined in the } 2006 \\
\text { IECC, is required. }\end{array}$ & & & & \\
\hline Residential & Simulated & \begin{tabular}{l|l|} 
Performance \\
\end{tabular} & 405.5 & 405.5.1 General. Except as & 702.2 Energy cost performance levels & & & & - \\
\hline
\end{tabular}




\begin{tabular}{|c|c|c|c|c|c|c|c|c|c|}
\hline Category & Topic & $\begin{array}{l}\text { Requireme } \\
\text { nt category }\end{array}$ & $\begin{array}{c}\text { IECC } \\
\text { Requirement } \\
\text { Reference } \\
\end{array}$ & IECC 2009 & ICC-700 & LEED for Homes & ES2 & ES2.5 & ES3 \\
\hline $\begin{array}{l}\text { Energy } \\
\text { Efficiency }\end{array}$ & $\begin{array}{l}\text { Performance } \\
\text { Alternative }\end{array}$ & & $\begin{array}{l}\text { Calculation } \\
\text { procedure. }\end{array}$ & $\begin{array}{l}\text { specifieed by this section, the } \\
\text { standard reference design and } \\
\text { propososed design shall be } \\
\text { configured and analyzed using } \\
\text { identical methods and } \\
\text { techniques. } \\
\text { 405.5.2 Residence } \\
\text { specifications. The standard } \\
\text { reference design and proposed } \\
\text { design shall be configured and } \\
\text { analyzed as specified by table } \\
\text { 405.5.2(1). Table 405.5.2(1) } \\
\text { shall include by reference all } \\
\text { notes contained in Table 402.1.1. }\end{array}$ & $\begin{array}{l}\text { (Performance Path). Energy efficiency } \\
\text { features are implemented to achieve } \\
\text { energy cost performance that exceeds the } \\
2006 \text { IECC by the following. A } \\
\text { documented analysis using software in } \\
\text { accordance with } 2006 \text { IECC, Section } \\
\text { 404, or } 2006 \text { IECC Section } 506.2 \\
\text { through } 506.5 \text {, applied as defined in the } \\
2006 \text { IECC, is required. }\end{array}$ & & & & \\
\hline $\begin{array}{c}\text { Residential } \\
\text { Energy } \\
\text { Efficiency }\end{array}$ & $\begin{array}{l}\text { Simulated } \\
\text { Performance } \\
\text { Alternative }\end{array}$ & Performance & $\begin{array}{l}405.6 \\
\text { Calculation } \\
\text { software tools. } \\
405.6 .1 \\
\text { Minimum } \\
\text { capabilities. }\end{array}$ & $\begin{array}{l}\text { Calculation procedures used to } \\
\text { comply with this section shall be } \\
\text { software tools capable of } \\
\text { calculating the annual energy } \\
\text { consumption of all building } \\
\text { elements that differ between the } \\
\text { standard reference design and the } \\
\text { proposed design and shall } \\
\text { include the following } \\
\text { capabilities: }\end{array}$ & $\begin{array}{l}702.2 \text { Energy cost performance levels } \\
\text { (Performance Path). Energy efficiency } \\
\text { features are implemented to achieve } \\
\text { energy cost performance that exceeds the } \\
2006 \text { IECC by the following. A } \\
\text { documented analysis using software in } \\
\text { accordance with 2006 IECC, Section } \\
\text { 404, or 2006 IECC Section 506.2 } \\
\text { through 506.5, applied as defined in the } \\
\text { 2006 IECC, is required. } \\
\end{array}$ & - & - & - & - \\
\hline $\begin{array}{c}\text { Residential } \\
\text { Energy } \\
\text { Efficiency }\end{array}$ & \begin{tabular}{|l} 
Simulated \\
Performance \\
Alternative
\end{tabular} & Performance & \begin{tabular}{|l}
405.6 \\
Calculation \\
software tools. \\
405.6 .1 \\
Minimum \\
capabilities.(1)
\end{tabular} & $\begin{array}{l}\text { Calculation procedures ... and } \\
\text { shall include the following } \\
\text { capabilities: } \\
\text { 1. Computer generation of the } \\
\text { standard referencece design using } \\
\text { only the input for the proposed } \\
\text { design. The caclcultation } \\
\text { procedure shall not allow the } \\
\text { user to do directly modify the } \\
\text { buildding component } \\
\text { characteristics of the standard } \\
\text { reference design. }\end{array}$ & $\begin{array}{l}702.2 \text { Energy cost performance levels } \\
\text { (Performance Path). Energy efficiency } \\
\text { features are implemented to achieve } \\
\text { energy cost performance that exceeds the } \\
2006 \text { IECC by the following. A } \\
\text { documented analysis using software in } \\
\text { accordance with 2006 IECC, Section } \\
\text { 404, or } 2006 \text { IECC Section } 506.2 \text { through } \\
\text { 506.5, applied as defined in the } 2006 \\
\text { IECC, is required. }\end{array}$ & - & - & - & - \\
\hline $\begin{array}{c}\text { Residential } \\
\text { Energy } \\
\text { Efficiency }\end{array}$ & \begin{tabular}{|l} 
Simulated \\
Performance \\
Alternative
\end{tabular} & Performance & \begin{tabular}{|l|}
405.6 \\
Calculation \\
software tools. \\
405.6 .1 \\
Minimum \\
capabilities.(2)
\end{tabular} & $\begin{array}{l}\text { Calculation procedures.... and } \\
\text { shall linclude the following } \\
\text { capabilities: } \\
\text { 2. Calculation of whole-building } \\
\text { (as a single zone) sizing for the } \\
\text { heating and cooling equipment in } \\
\text { the standard reference design } \\
\text { residence in accordance with } \\
\text { Section M14140.3 of the } \\
\text { International Residential Code. }\end{array}$ & $\begin{array}{l}\text { 702.2 Energy cost performance levels } \\
\text { (Performance Path). Energy efficiency } \\
\text { features are implemented to achieve } \\
\text { energy cost performance that exceeds the } \\
2006 \text { IECC by the following. A } \\
\text { documented analysis using software in } \\
\text { accordance with 2006 IECC, Section } \\
\text { 404, or 2006 IECC Section 506.2 through } \\
\text { 506.5, applied as defined in the } 2006 \\
\text { IECC, is required. }\end{array}$ & - & - & - & - \\
\hline $\begin{array}{l}\text { Residential } \\
\text { Energy } \\
\text { Efficiency }\end{array}$ & \begin{tabular}{|l|} 
Simulated \\
Performance \\
Alternative
\end{tabular} & Performance & $\begin{array}{l}405.6 \\
\text { Calculation } \\
\text { software tools. } \\
405.6 .1 \\
\text { Minimum } \\
\text { capabilities.(3) }\end{array}$ & $\begin{array}{l}\text { Calculation procedures ... and } \\
\text { shall include the following } \\
\text { capabilities: } \\
\text { 3. Calculations that account for } \\
\text { the effects of indoor and outdoor } \\
\text { temperatures and part-load ratios } \\
\text { on the performance of heating, } \\
\text { ventilating and air-conditioning } \\
\text { equipment based on climate and } \\
\text { equipment sizing. }\end{array}$ & $\begin{array}{l}\text { 702.2 Energy cost performance levels } \\
\text { (Performance Path). Energy efficiency } \\
\text { features are implemented to achieve } \\
\text { energy cost performance that exceeds the } \\
\text { 2006 IECC by the following. A } \\
\text { documented analysis using software in } \\
\text { accordance with } 2006 \text { IECC, Section } \\
\text { 404, or 2006 IECC Section } 506.2 \text { through } \\
\text { 506.5, applied as defined in the } 2006 \\
\text { IECC, is required. }\end{array}$ & - & - & & \\
\hline $\begin{array}{l}\text { Residential } \\
\text { Energy } \\
\text { Efficiency }\end{array}$ & \begin{tabular}{|l|} 
Simulated \\
Performance \\
Alternative
\end{tabular} & Performance & $\begin{array}{l}405.6 \\
\text { Calculation } \\
\text { software tools. } \\
405.6 .1 \\
\text { Minimum } \\
\text { capabilities.(4) }\end{array}$ & $\begin{array}{l}\text { Calculation procedures ... and } \\
\text { shall include the following } \\
\text { capabilities: } \\
\text { 4. Printed code official } \\
\text { inspection checklist listing each } \\
\text { of the proposed design } \\
\text { component characteristics from }\end{array}$ & $\begin{array}{l}702.2 \text { Energy cost performance levels } \\
\text { (Performance Path). Energy efficiency } \\
\text { features are implemented to achieve } \\
\text { energy cost performance that exceeds the } \\
2006 \text { IECC by the following. A } \\
\text { documented analysis using software in } \\
\text { accordance with } 2006 \text { IECC, Section }\end{array}$ & & & & \\
\hline
\end{tabular}




\begin{tabular}{|c|c|c|c|c|c|c|c|c|c|}
\hline Category & Topic & $\begin{array}{l}\text { Requireme } \\
\text { nt category }\end{array}$ & $\begin{array}{c}\text { IECC } \\
\text { Requirement } \\
\text { Reference }\end{array}$ & IECC 2009 & ICC-700 & LEED for Homes & ES2 & ES2.5 & ES3 \\
\hline & & & & $\begin{array}{l}\text { Table 405.5.2(1) determined by } \\
\text { the analysis to provide } \\
\text { compliance, along with their } \\
\text { respective performance ratings } \\
\text { (e.g.,., R-value, U-facter, SHGC, } \\
\text { HSPF, AFUE, SEER, EF, etc.). }\end{array}$ & $\begin{array}{l}\text { 404, or } 2006 \text { IECC Section } 506.2 \text { through } \\
506.5 \text {, applied as defined in the } 2006 \\
\text { IECC, is required. }\end{array}$ & & & & \\
\hline $\begin{array}{l}\text { Residential } \\
\text { Energy } \\
\text { Efficiency }\end{array}$ & \begin{tabular}{l|} 
Simulated \\
Performance \\
Alternative
\end{tabular} & Performance & $\begin{array}{l}405.6 \\
\text { Calculation } \\
\text { software tools. } \\
405.6 .2 \\
\text { Specific } \\
\text { approval. }\end{array}$ & $\begin{array}{l}\text { Performance analysis tools } \\
\text { meeting the applicable sections } \\
\text { of Section } 405 \text { shall be permitted } \\
\text { to be approved. Tools are } \\
\text { permitted to be approved based } \\
\text { on meeting a specified threshold } \\
\text { for a jurisdiction. The code } \\
\text { official shall be permitted to } \\
\text { approve tools for a specified } \\
\text { application or limited scope. }\end{array}$ & $\begin{array}{l}\text { 702.2 Energy cost performance levels } \\
\text { (Performance Path). Energy efficiency } \\
\text { features are implemented to achieve } \\
\text { energy cost performance that exceeds the } \\
2006 \text { IECC by the following. A } \\
\text { documented analysis using software in } \\
\text { accordance with } 2006 \text { IECC, Section } \\
404 \text {, or 2006 IECC Section } 506.2 \text { through } \\
506.5 \text {, applied as defined in the } 2006 \\
\text { IECC, is required. }\end{array}$ & - & - & - & - \\
\hline $\begin{array}{c}\text { Residential } \\
\text { Energy } \\
\text { Efficiency }\end{array}$ & \begin{tabular}{l|l} 
Simulated \\
Performance \\
Alternative
\end{tabular} & $\begin{array}{l}\text { Performance } \\
\end{array}$ & $\begin{array}{l}405.6 \\
\text { Calculation } \\
\text { software tools. } \\
\text { 405.6.3 Input } \\
\text { values. }\end{array}$ & $\begin{array}{l}\text { When calculations require input } \\
\text { values not specified by Sections } \\
402,403,404 \text { and } 405 \text {, those } \\
\text { input values shall be taken from } \\
\text { an approved source. }\end{array}$ & $\begin{array}{l}\text { 702.2 Energy cost performance levels } \\
\text { (Performance Path). Energy efficiency } \\
\text { features are implemented to achieve } \\
\text { energy cost performance that exceeds the } \\
\text { 2006 IECC by the following. A } \\
\text { documented analysis using software in } \\
\text { accordance with } 2006 \text { IECC, Section } \\
\text { 404, or IECC Section 506.2 through } \\
\text { 506.5, applied as defined in the IECC, is } \\
\text { required. }\end{array}$ & - & - & & - \\
\hline
\end{tabular}





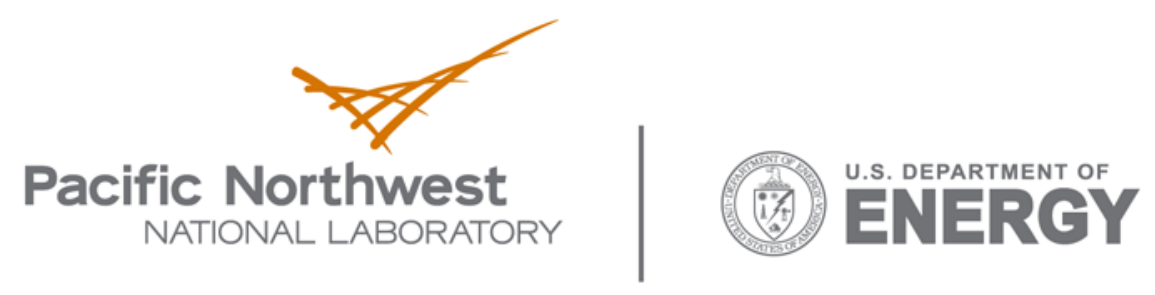

902 Battelle Boulevard

P.O. Box 999

Richland, WA 99352

1-888-375-PNNL (7665)

www.pnl.gov 